\title{
I-10027-0057
}
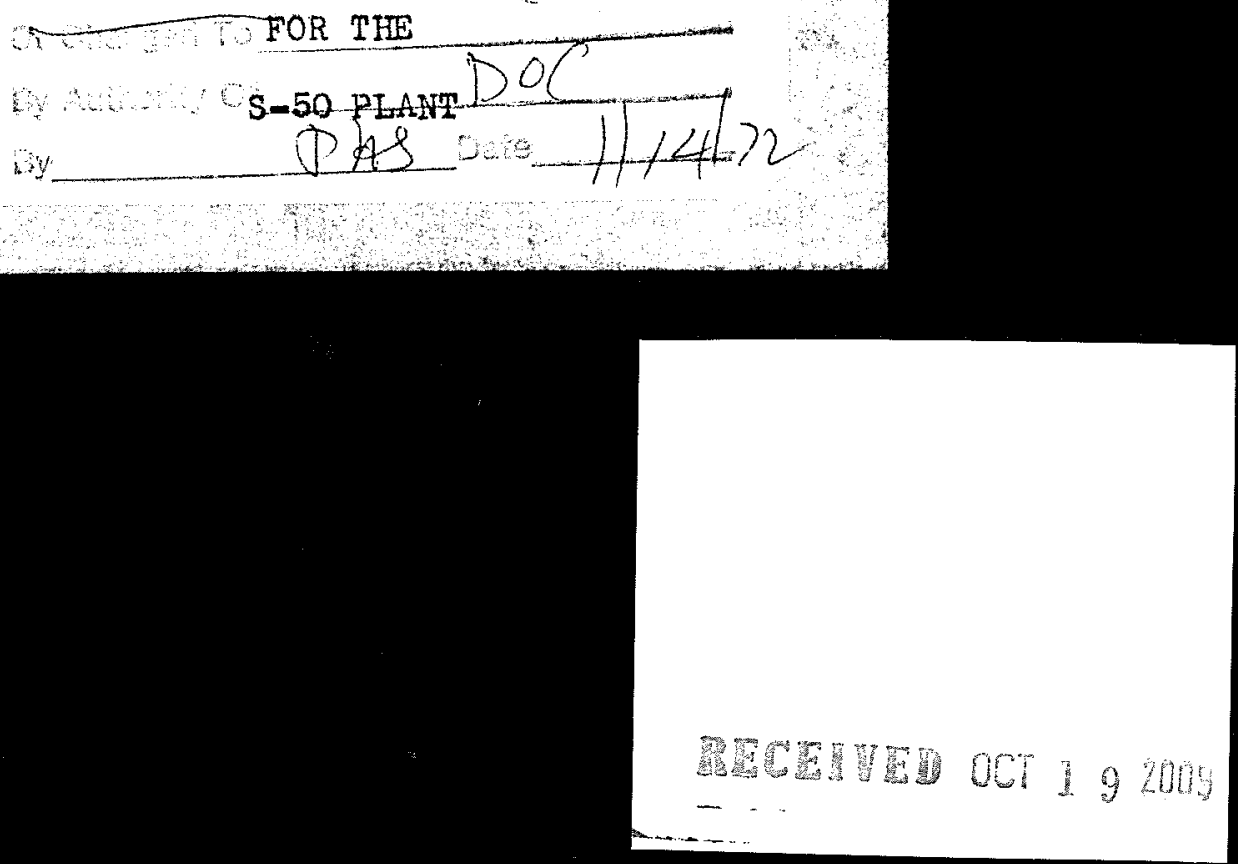
Tore compration

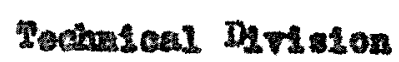

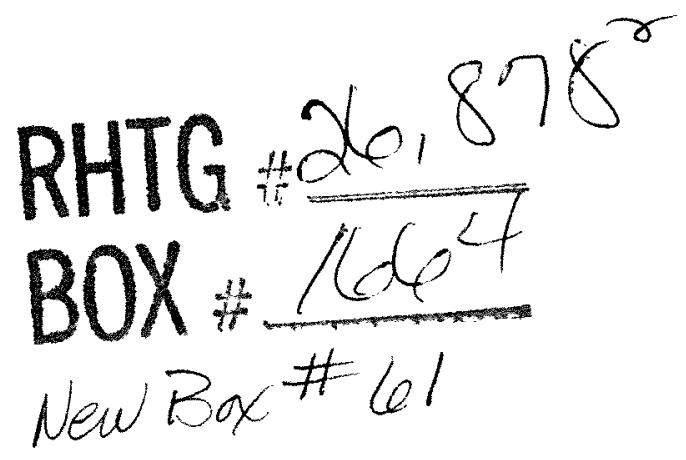

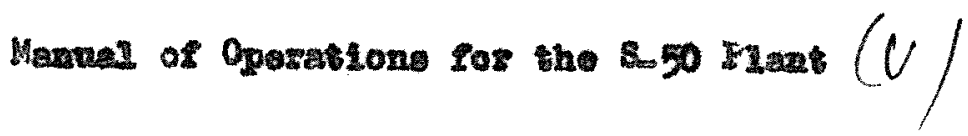

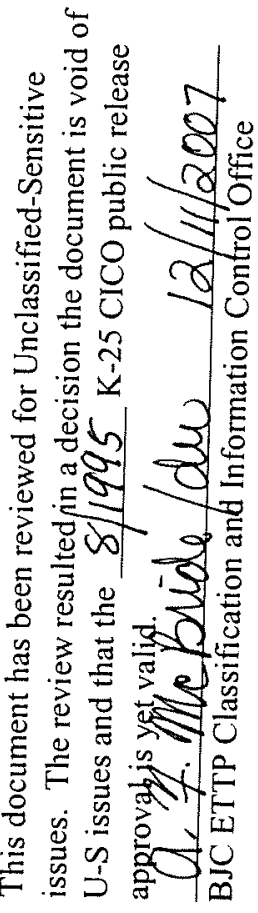

Jnan: 2945

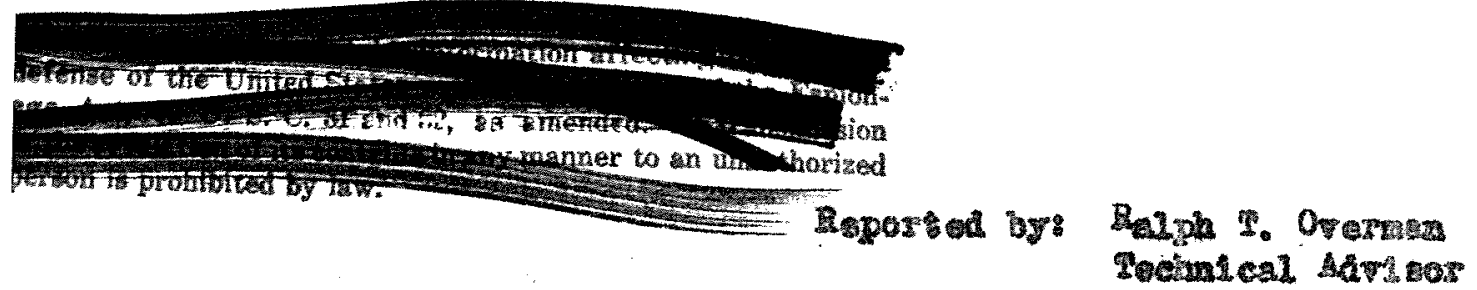

This document has been approved for relese to-the public by 


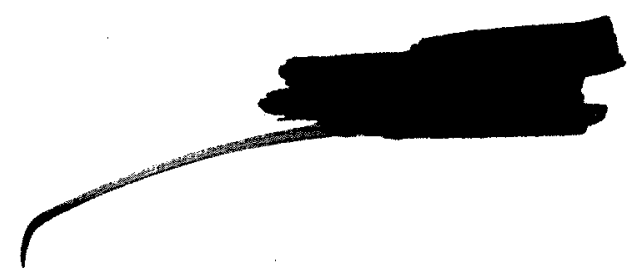

MORZNORD

It 18 recognt zed that the 850 plant operations are far from standardiged and therefore am manual wil require continual revision to keer 14 up to date. brea during the pertad of rriting this first edition, many changes occurred and were incorporated in the manal. Such revielons coold delaj indefinitely the isfruance of the manual and 1 was folt thet in its present form fit could be aseful in the training of new plant the mannsi The unc.ersigned was ongaged in extensive editing of would like when 1 became apparent that all the rerislons he would Ilke to mak" would delay unduly eren the issulng of this for use in connection therefore relesed at this time solely for use in connection with the training progran.

Barnatt F. Dodeo

Techalcal Directór

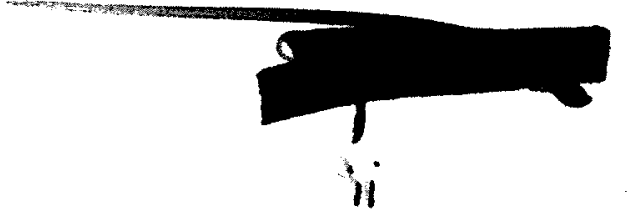


lage lo.

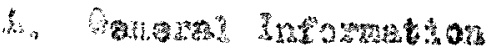

$A \rightarrow$

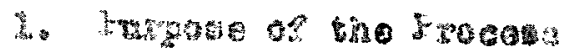

$A_{n=2}$

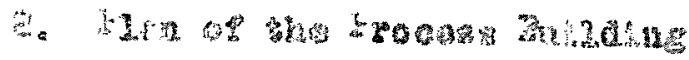

A. 28,2

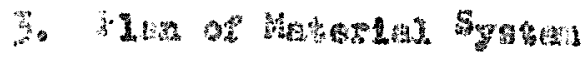

And 2,

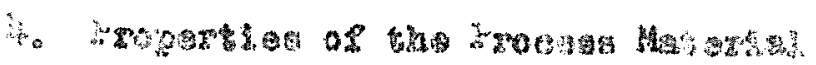

A. 3.

5. basa of

hes, A. 3 .

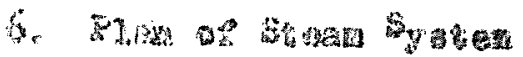

$\sin 10.6$

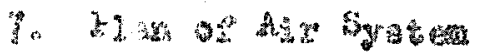

Ans 1.3

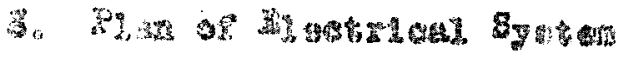

Aer 15

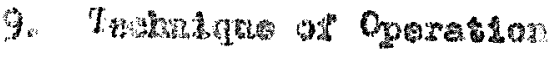

Ato $15, A, y$

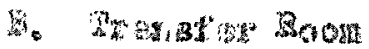

Din 1

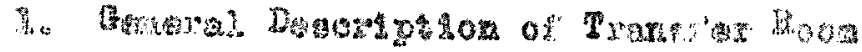

E. 1; 1: 1:

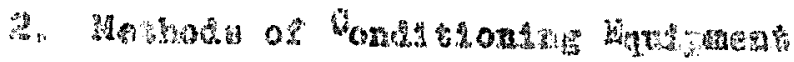

Bus, $4,2$.

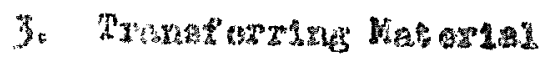

Ho

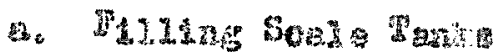

Ro?: 8

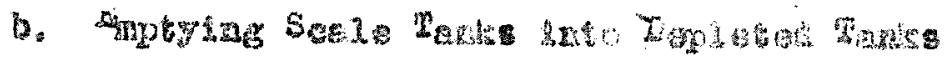

Los, 8

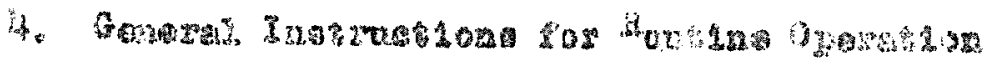

B. $9: \quad 3-5$

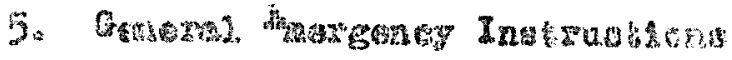

$\mathrm{B}-1$

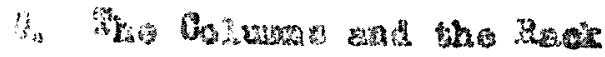

a. 1

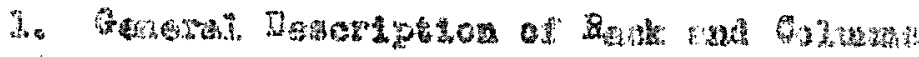

C.2.

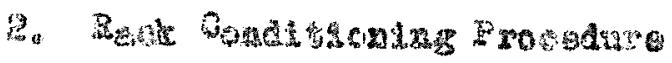

A.4. 6.3

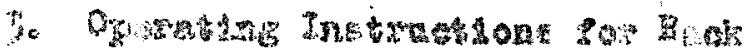

a. 11

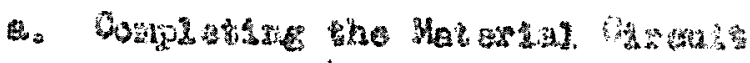

con. 4.2

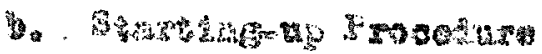

6ole 


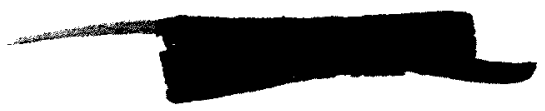

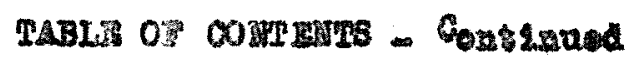

4. F1112ng the hes

בage

5. Loeating and H1matine IIng

2.13. C.15

215. $\mathrm{c} 28$

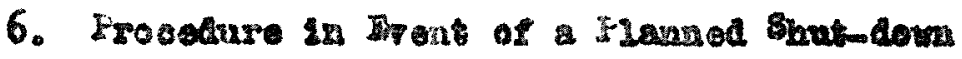

2.28, 0.29

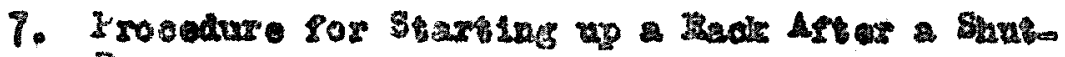
Dova

2.29, a. 32

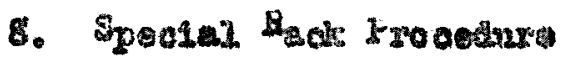

2.31. C.32

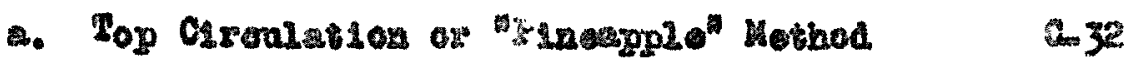

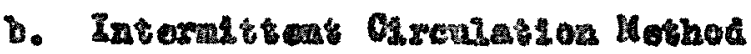

hes

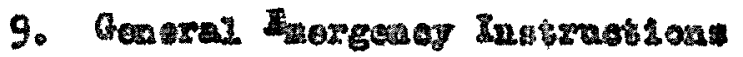

$233 . c-34$

20. Coasrol Roon an Contzol Dortoen

4. $34 \cdot 6.35$

D. Sampisas Yrocedruses

Da

1. Samplese of Colvme

2.1.

2. Sampling through " "gn"

D?

3. Sampling O4calt With Sop Orroulatsos gretan

D2. 203

4. Searplens of Capraze:

I. 3

5. Soupling scele Tanks

23

遇1

2. Frinchples of Iroduct Wh tharewal

1.1.5

2. Oparation of Manat Malking Systen wth Broeno-ors Colls

琵5.

3. Instruocione for Opexats on of Anatomatio Miliring Appsratu U Ung the Bol wotd. Talve systo

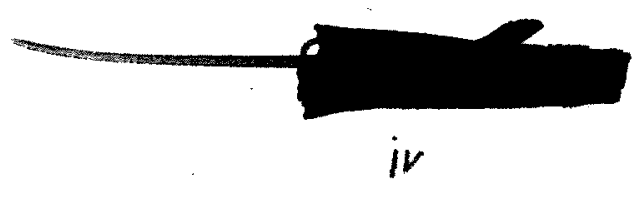




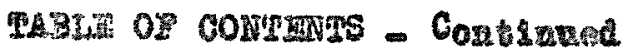

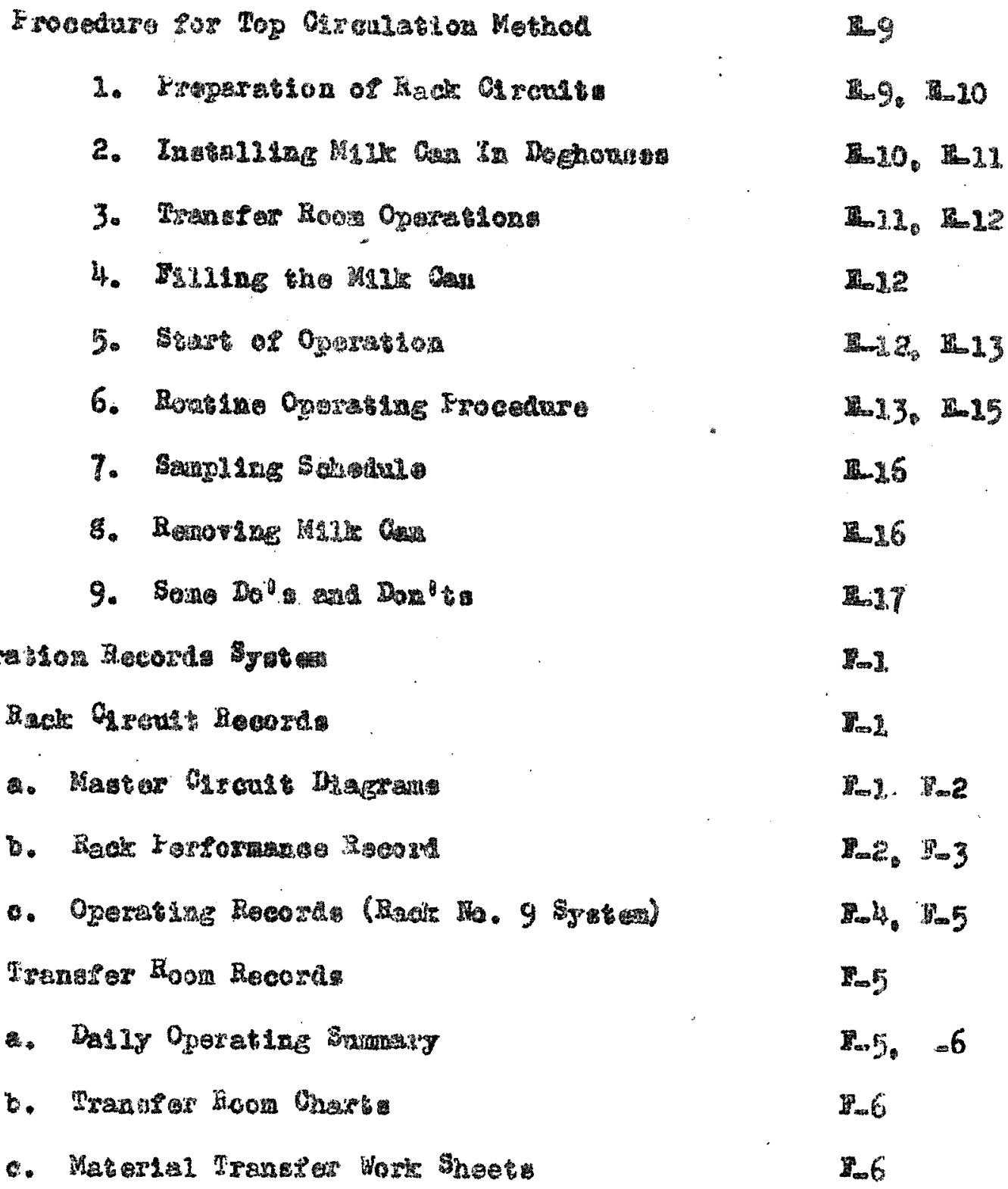

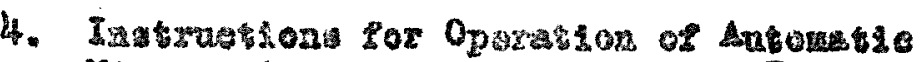

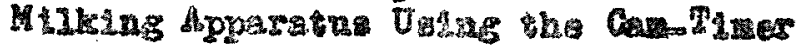

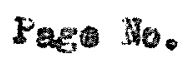

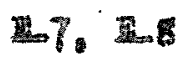

1.9

I. 20

20. 21

L. 1,2

1.3. 15

B. 15

5. Rerrovare

26

17

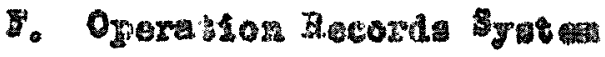

Tes 1

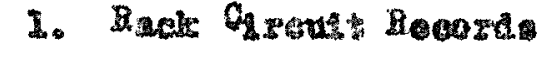

Hal. -2

Pod. 9.3

Hes. 5

2. Trang:er $\mathbb{K}_{\text {oon }}$ Recond

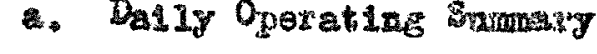

1.5.5. -6

c. Materlal Traneser Work Sheet

106

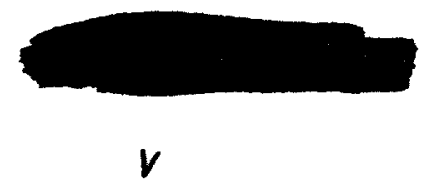


TABII OP CONPHMS - Oontimued

3. Iog Booke

Jage Ho.

- Baok Iog Books

I-7

b. Pranter Hoon Iog Book:

B.7

- Suporlntendents and Asstetante Log Books

I.7

2-7

4. Somonary

I.7. I-8

C. Plent Mesgeno Inotruotiens

a.

1. Contzin Derdoea

a. a. a

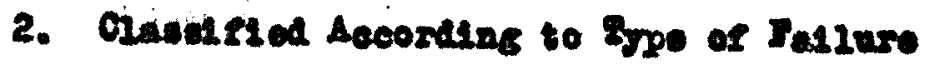

a.2, a. 7

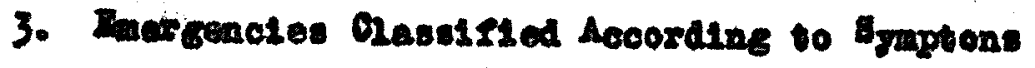

2.7. . 9

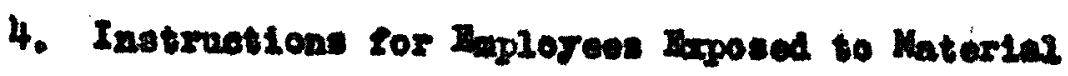

a. 0.10

4. Matudate Boetion Froocduree

L.2

1. Conditiontas Frocedures

B.1

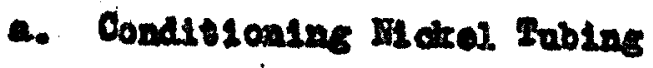

E.1

b. Deconditionting Iquifment

H1, H2

- Conditsoning Oanges

1.2. 14

2. Matersal Irancior

I5. ㄴ.6

3. Booont syatent

86

a. Bample Recerde

R.7

b. Mated al Removal Rooox

H. R.8

- Dquipaens Pesorde

I.6

$1-2$

I. Seourater 


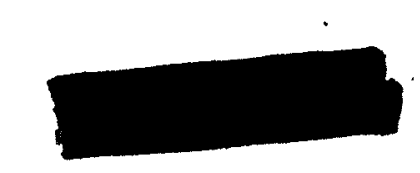

LISE ON DAATING

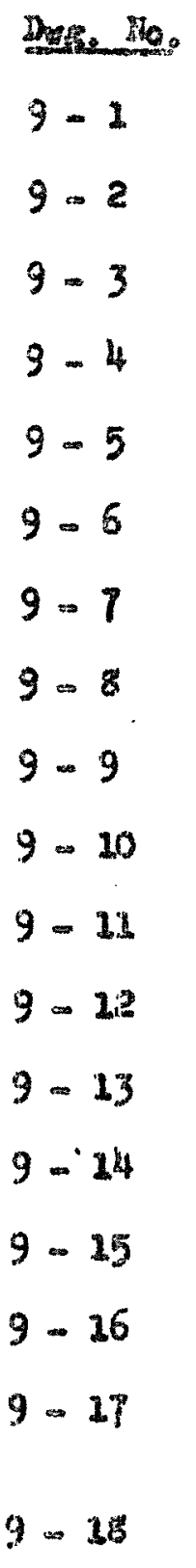

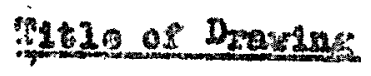

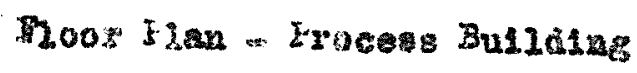

Feogrgage

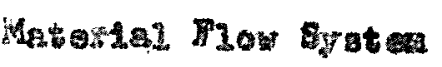

A.2

$\Delta 3$

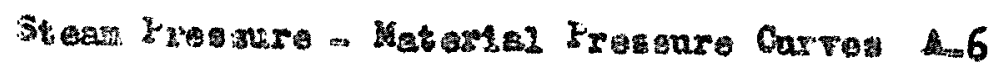

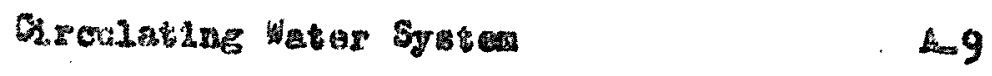

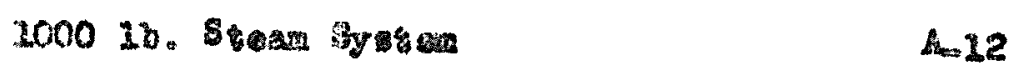

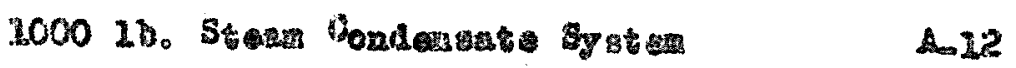

Iow

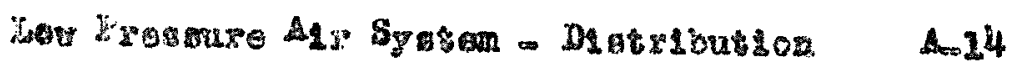

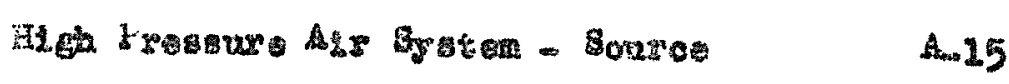

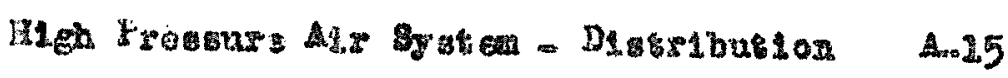

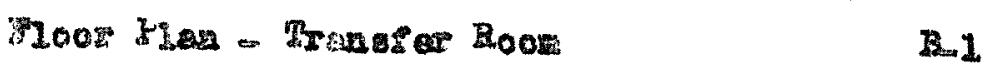

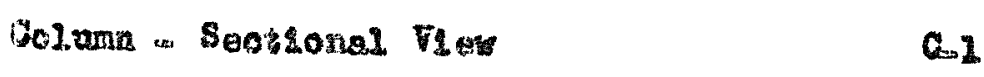

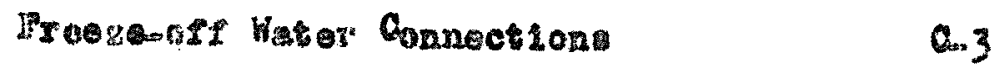

Golusa - Stean and water Connecsiono Cu

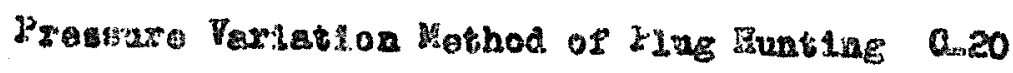

Control Boon Eanel Board C 35

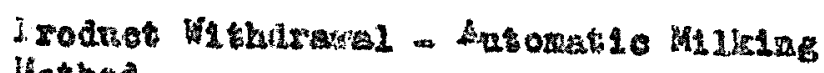
Hethed

B.

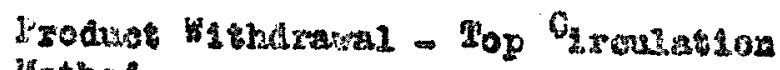

Hothen

19 
MANTOAL ON OKMRATIONS

WHE FEROLEVE CORLORATION

Soction 4. Gemeral Information

\section{The Furpose of the Frocesa}

The spectife purpose of the process employed by the Farcleve Corporation in the plant at Oak Bidge, Tennesses, is ono of secret informetion and cannot be released hero. It can be statod, howover. that tho jiant operation involves the processing of a chomicel substanco. Thi substance is not identified in the plant or in the process bat is soperred to only as material". Ito codo desienation is C.616. The process in general involvas the - eparation of the raw meterial into constituents with moro denirabl propertieg. It is not neceasary to know the name of the maserlal nor the exact nature of the procees in order to carry out the operations so thi information will not bo given in thi: Manual.

The problen larolved is to traneport the material erom the contalnero in which it is recelved by the plant into the equiprent netup in tho plant $10 \mathrm{~s}$ carrysng out the opertition. to remor tho various product frow the yrociss oquipment and to do othor auxlliary operations.

\section{Tho Ilan of the troceas Butzding}

The S-50 Area constste of one priactpal building. callod the procese bullding with the following abolalary bulidinges

(1) Fump Houso

(2) Wate: Treatment Boslding

(3) Jower House

(4) Laboratory No. 1

(5) Inboratory $\mathrm{NT} 0.2$

(6) Ferclove Admial stretion Ofilce

(7) Warehouse, Matnt : nance and Machine Shop

(8) Timo OP\$1ce and Cafoteria

(9) Change House 


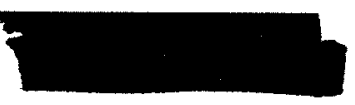

A -2

The process bodlding contaln 21 ldentical operating units called racks. Therefore, if one has on urderstanding of the funotion and operation of one of these racks with 148 avxiliary equipmont, he v111 undergtand the whole operation of all of then. Those 21 racks are arrangod in groups of 7 which are designated by the term gections. Fuch of the section is oupliled with steem by a main stean l1ne retezred to es SF-1. 5t-2, and $55-3$. The sections are mubered according to this designation. Thue rack 1-7 are suppl1ed by $5-3$. rackg 8-14 are

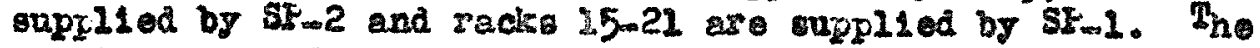
sect10ns are 1dent1cal in operation but are norely arranged in this manner to simplify the distibution of ctean to the racks. The 2200 r plan of tho grocens bullding is shown in Dwe. gal.

For each 2 radks shere lo a tranefor room located on the I1rat lerel above the floor along the was side of the builaing. Since there is an odd number of rack, rack 21 is lerved by ons trensfer room. Int sack 1 a consldexed to be an experimental rack; $1 t$ and 1 ts transfor and control roons are under the direction of the Teanter DLIaLon.

Fer each peis of stack there is al wo one control room. making a total of 11 conáro: rooms. Thes rooma are locatod next to the rranter zoome in the mezanino $16 \mathrm{vel}$.

The Irecess bulding consigts then yrimarly of these racks, control and transer room w1th the rest of the equipment boine usod to upIly ste:m, water and aif to the systems. There systems will be described in detali in other parts of this section.

\section{Elan of Matertal Srgtem}

Back of the rack in the process bullding consists of 102 column arranged in row of 51 columne oach. Fach of the columns 1. Im1lar, in that $1 t$ constses of concentric plpes through which is passed steam, materiel and vator. The meterlal is passed into the second of the threo concentric plpos. Thns, the material has steam on one side of 15 in the center plyo and wator on the outgide in the outer fipe.

The meterlal channel of the columne are then connocted together w1th mall dianoter niakel tubing at the bottoms so that the columns are essentially a serles of atandifigo in a 11no. The material 1. passed from the scalo tarks in the transfer roon into the rack through nickel tuber called condults encased by a stean jacket. The storage tan'r are located on the second level in the tranefer rooms. In the transfer room also are locetod the shipplng tanks in which the material is brought into the plant and in which it 18 semored. 


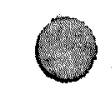

0

둥

2

Want
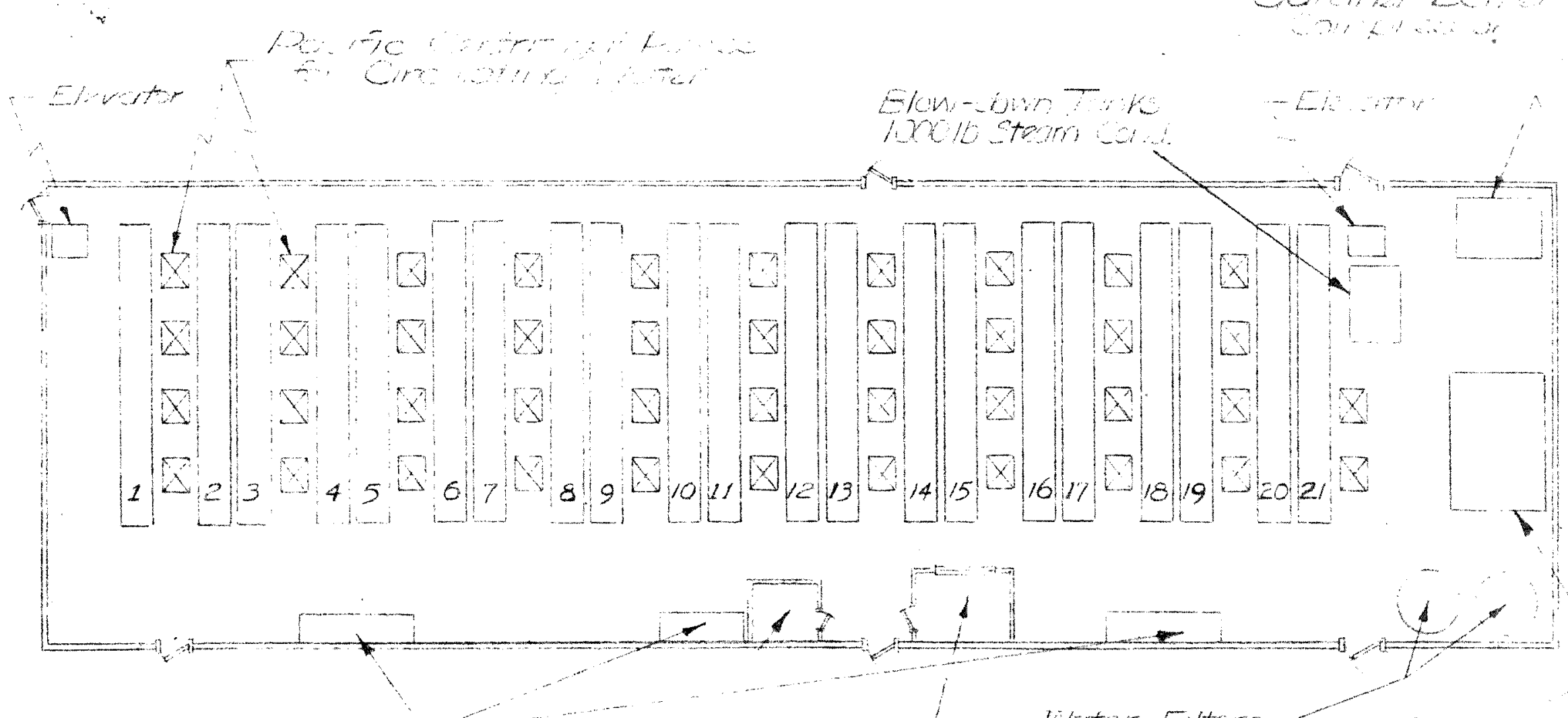

Etothal Contrit Bown
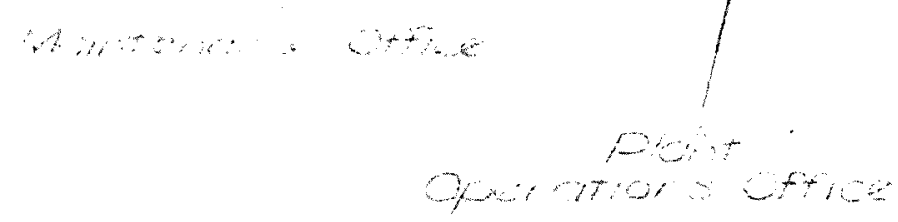

Whter Fitters

$$
\begin{aligned}
& \text { atedr: } x_{2} \\
& \text { Cow wa }
\end{aligned}
$$




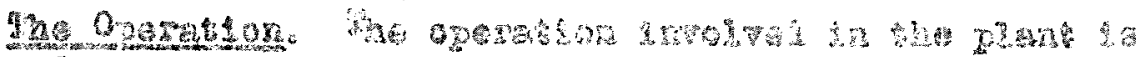

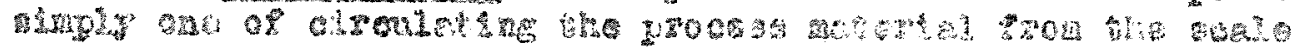

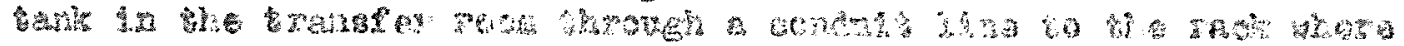

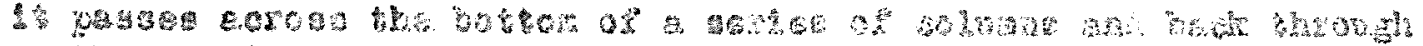

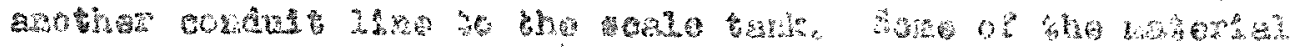

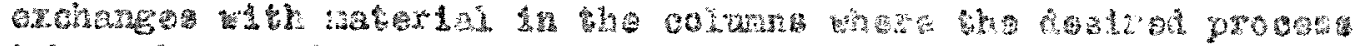

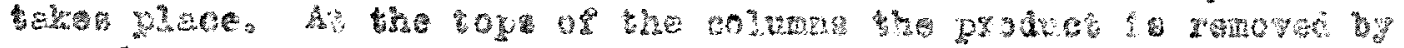

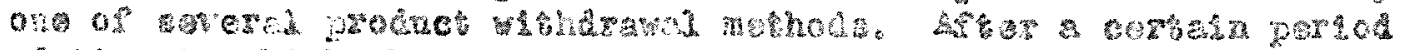

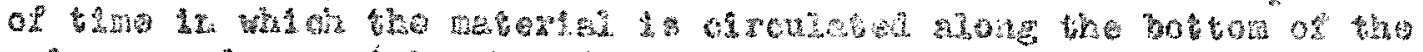

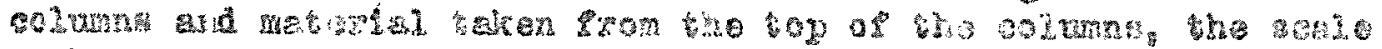

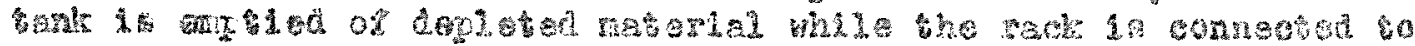

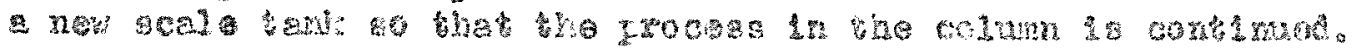

C

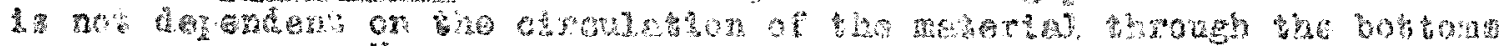

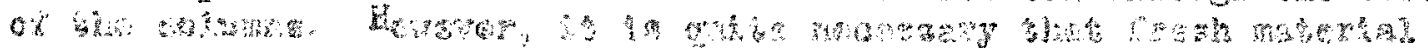

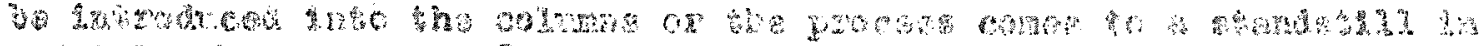

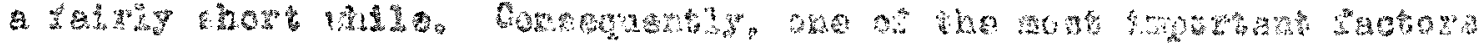

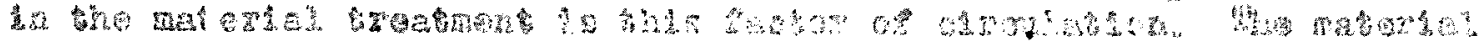

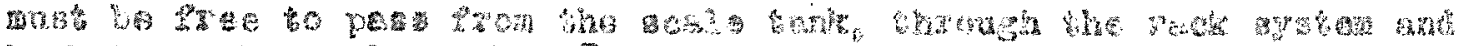

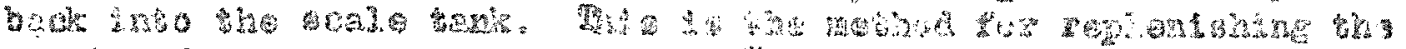

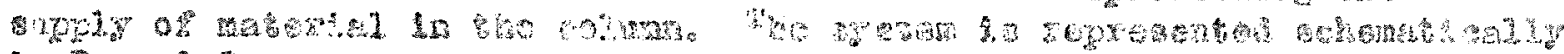
in Dug. Ge

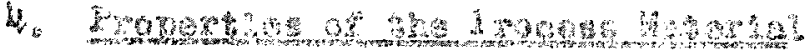

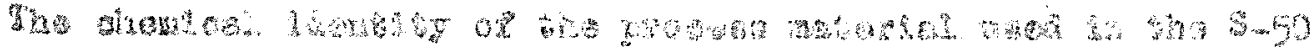

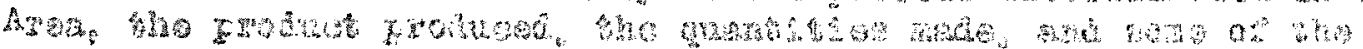

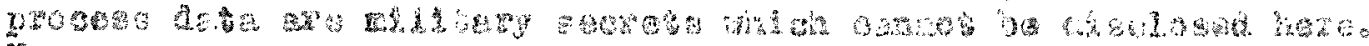

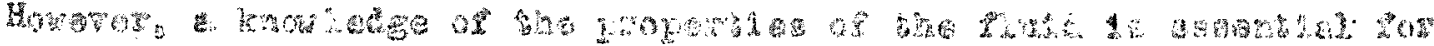
Or

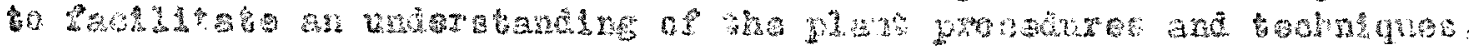

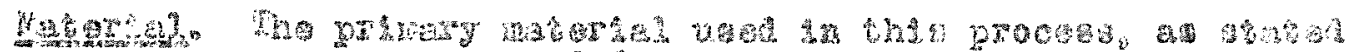

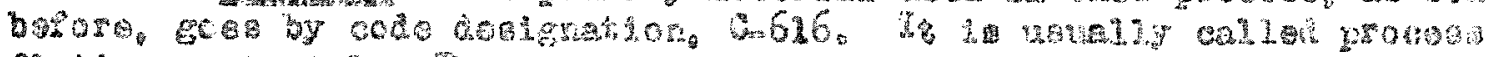

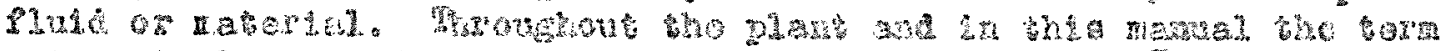

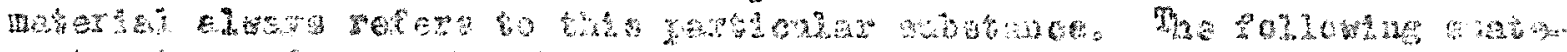

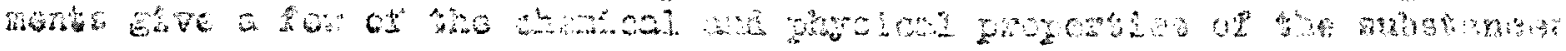

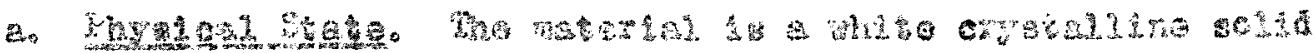

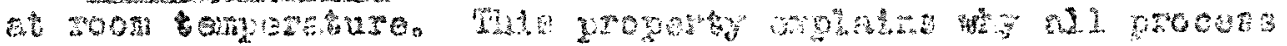

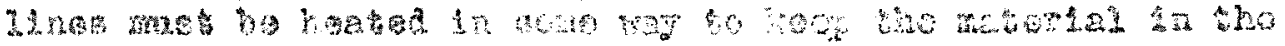

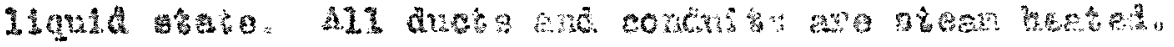




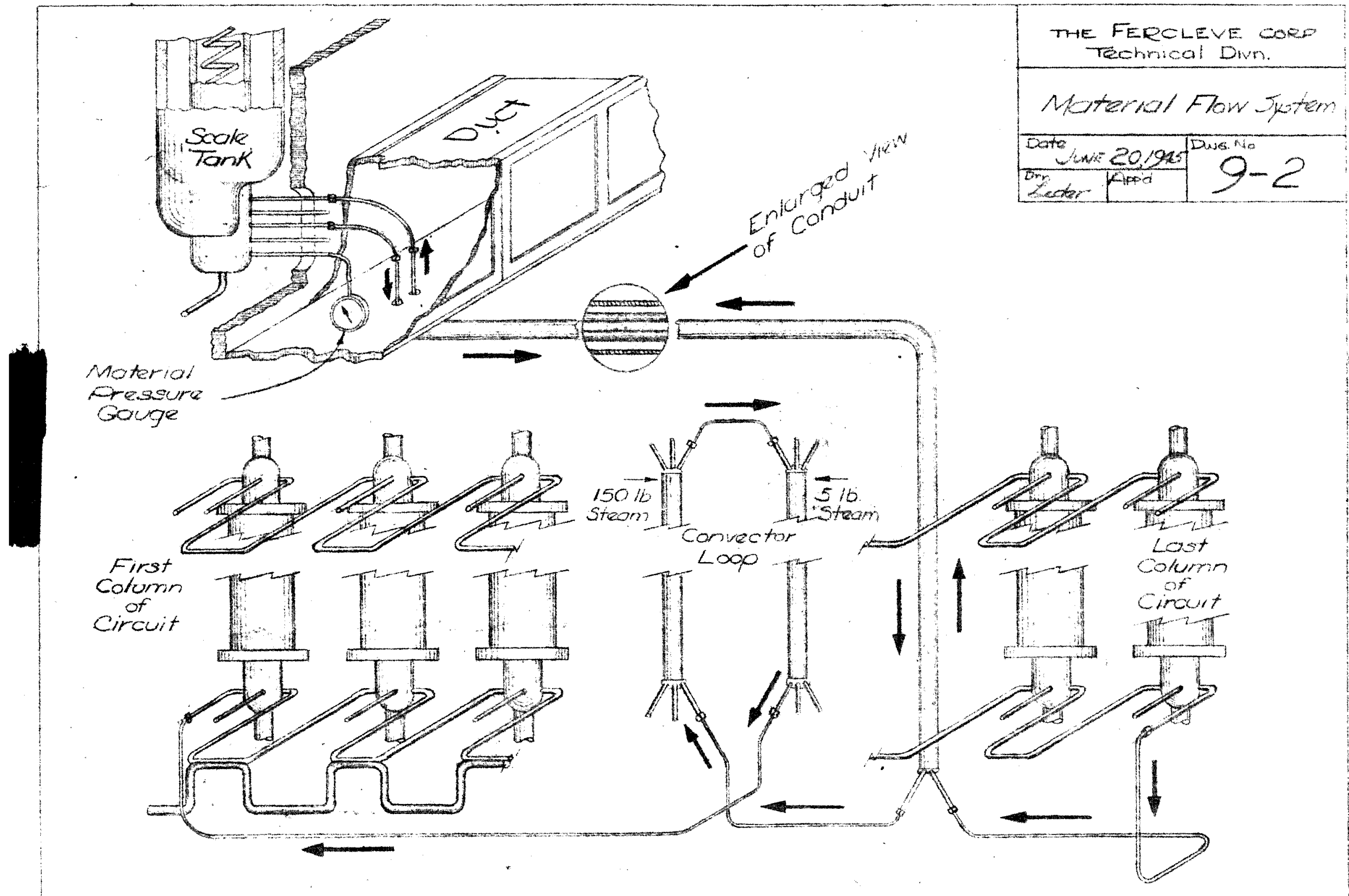


b. Melting Yolnt. The meterial sublines (changes drectly fron

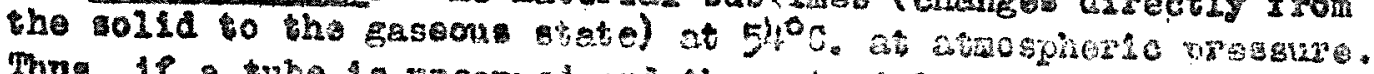

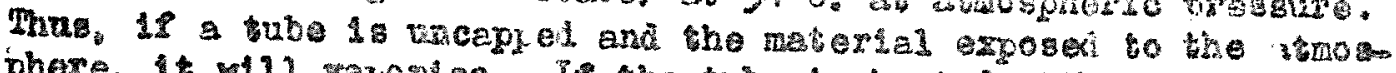

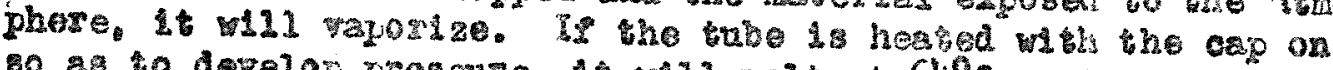

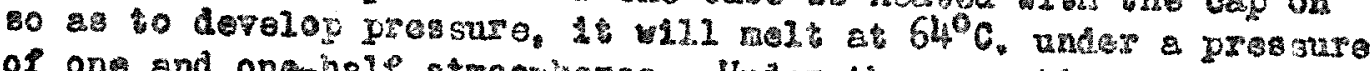
of one and onehale strogyeres. Under the operating pressure

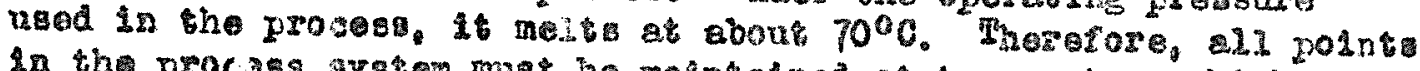
In the procss aysen mat bo mantalned at tengeretures highor then $70^{\circ} \mathrm{C}$. so thas plug of solidisted material wil. not bo sormod.

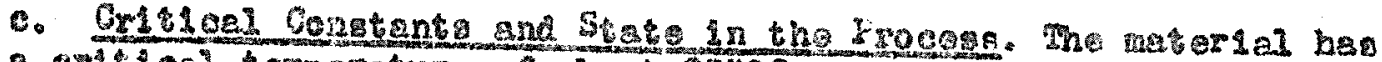

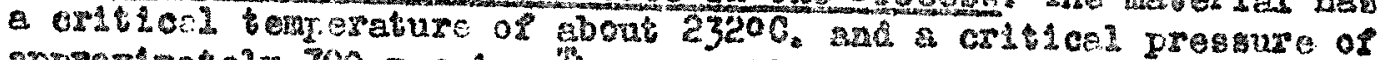

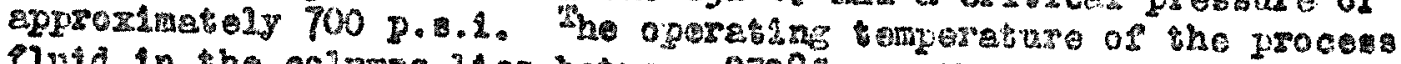
Flutd in tho colann 11 a betwear $270^{\circ}$. on the not gad and $70^{\circ} \mathrm{C}$. on the cold adoibowerer, because of the high aperateng preasure. 1500

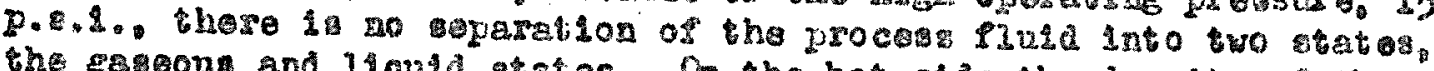

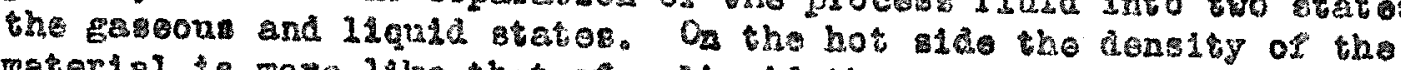

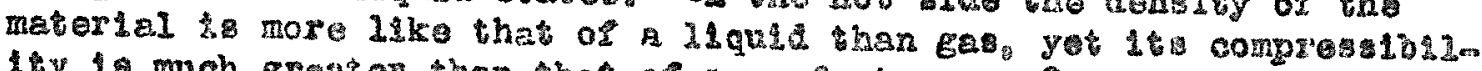

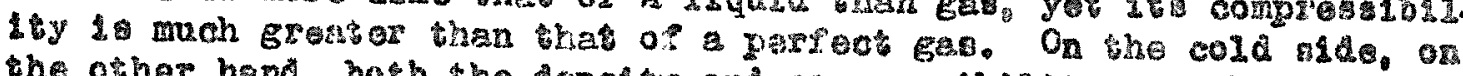

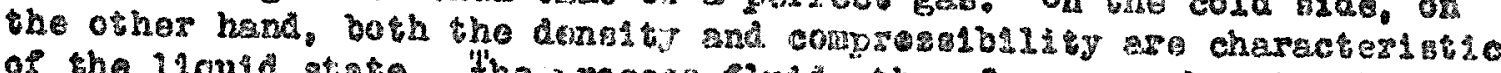

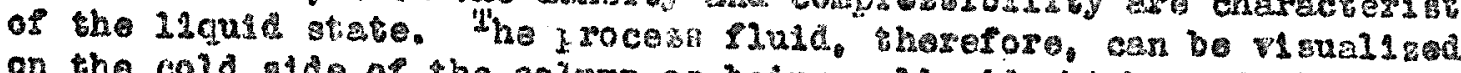
on the cold slde of the column as bosng a liquLa wheir gradualy and

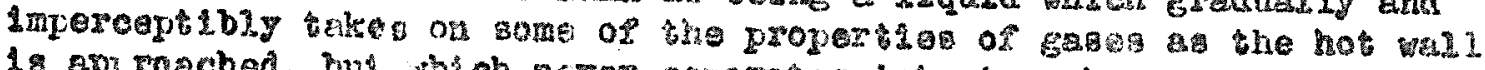

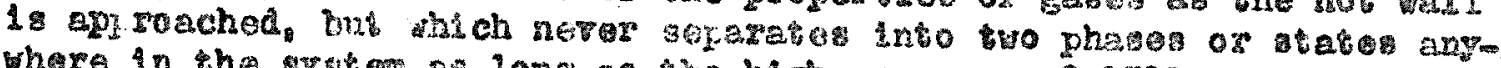

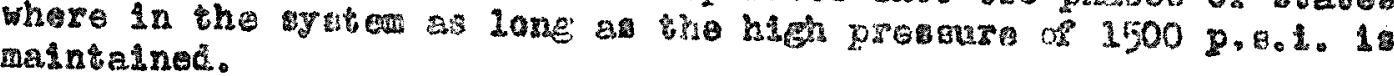

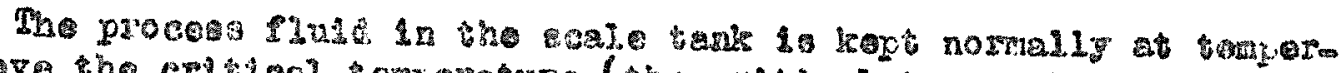

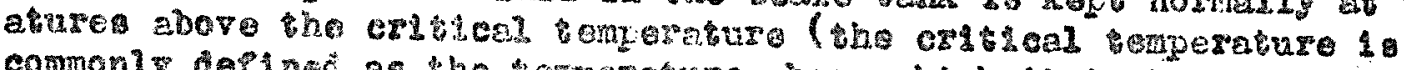

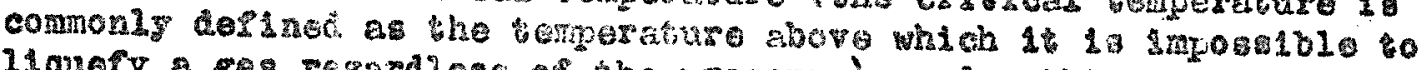
11quefy a ges regardiese of tho prossurel under this conditon and the

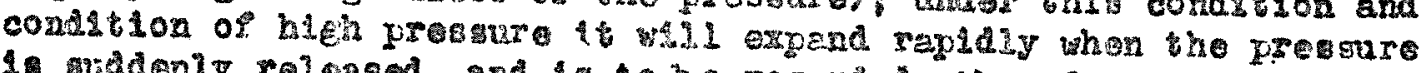

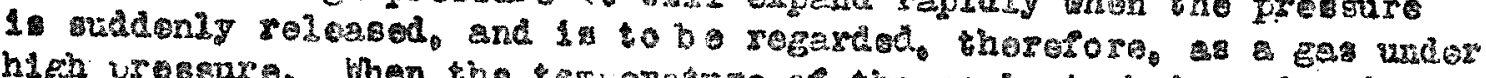

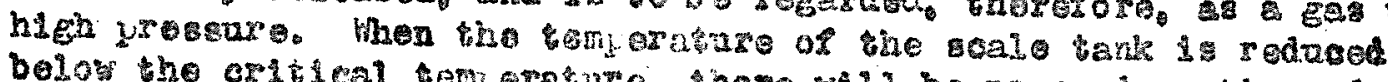

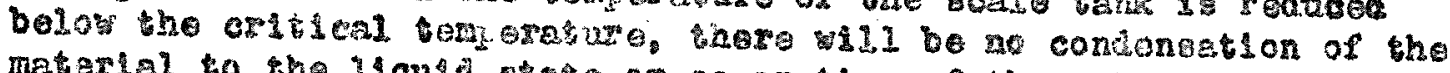

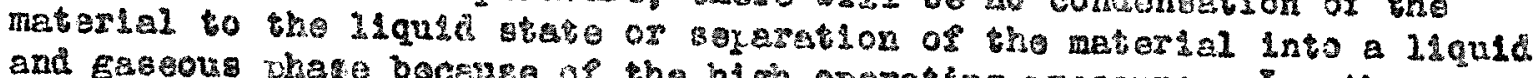
and Easeous thete bocense of the nigh oporating jressure. In other

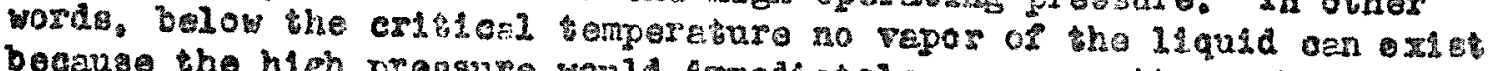

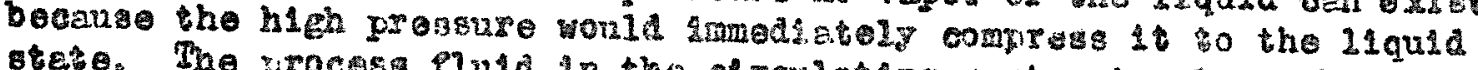

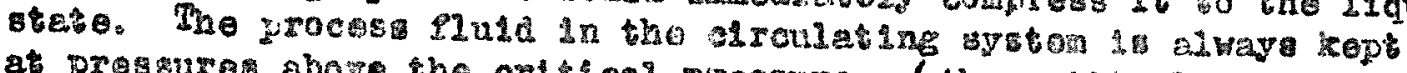

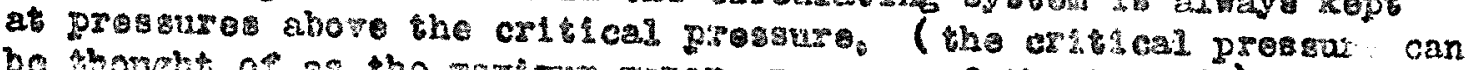

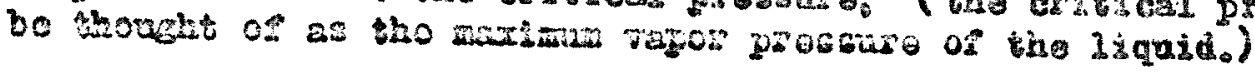

d. Peaclon with Wates. The material reacis rapldig with vater to

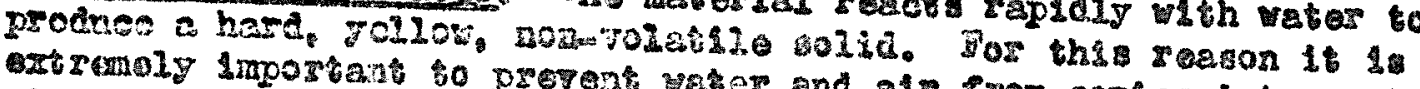

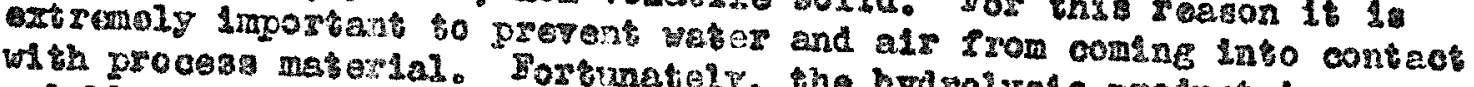

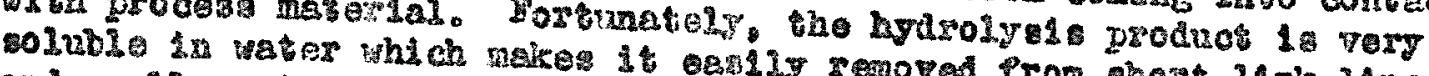
and anel2 oqulpment. 
$A=5$

Watez mat be kept out of the process systar ab all costo as mall amounis nf water will resot with tho procoss flult groducing

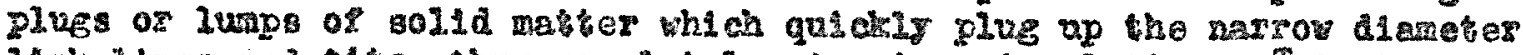

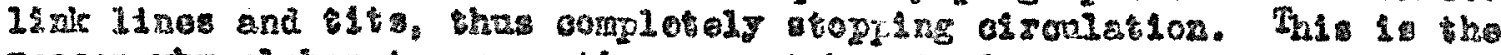

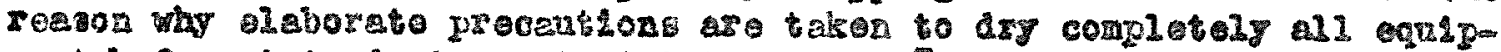

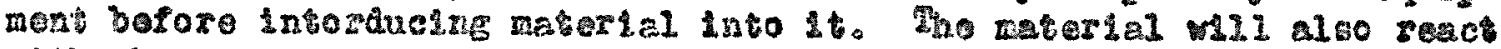

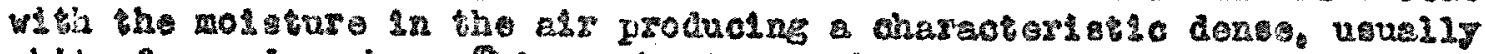

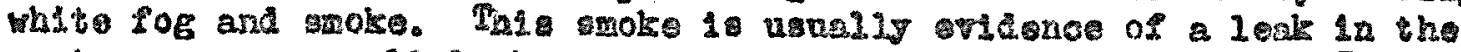

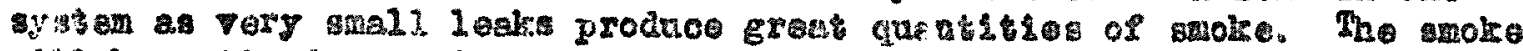

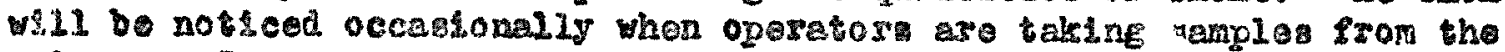

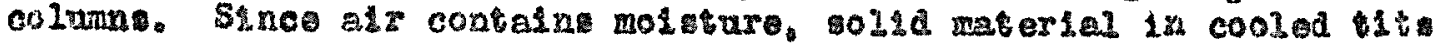

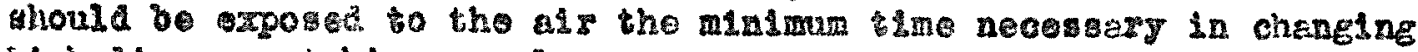
init linos or telsing aemplos.

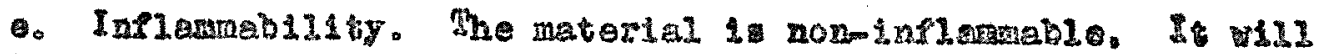
impart a yolow color so a gas flame, howerar, the froperty is urom

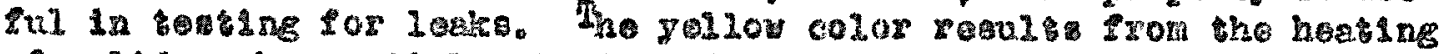

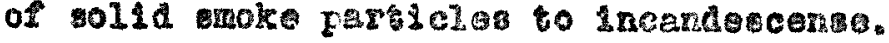

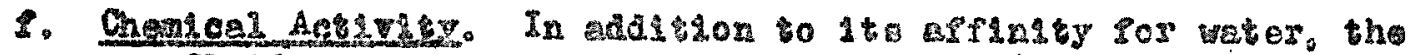

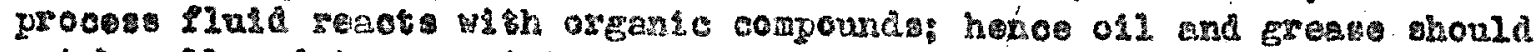
not bo allowed to cono 1 nto contect wh the Pludi otherrise tho circulatsng sybtom 1211 plog ae montioned above in the cast of trater.

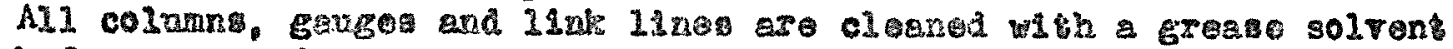
baior use and vacuan purap. which conteln o11, aze protected fron mesarlati fures by 200 and charooal traps.

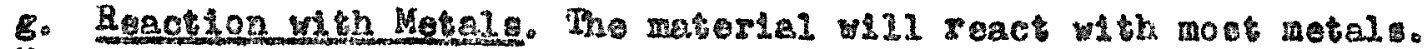

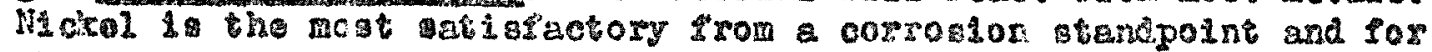
this reason most of the equipment in the plaxt 1 a made of puse nickel. Oopver 1 also falriy good and 1 u ued. The bigh presere mater lal. gauger uad in the vlant are made in perst of berylilum copper alloy. Steal houd bo arotead alnce its corrosion by the process lluld is relat 1rely reple.

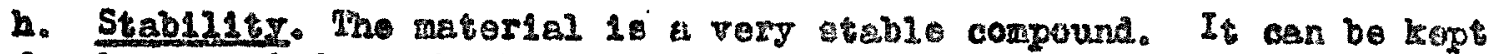
for long perdods at high temeratures in contact wh nh nickl without decompost\$10n.

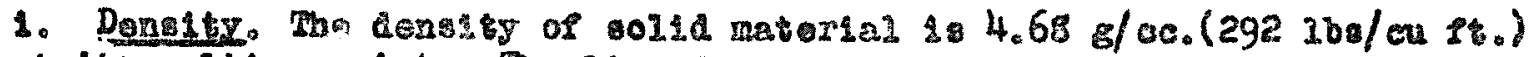
at 103 molbine Eolnt. The 22qus. as the molting point has a density of $3.7 \mathrm{~g} / 00$. Thu ther 1.3 a Folumo increas of $35 \%$ in going from the sold to the IIquid state, andige in rolume whith is abnoznally bigh. ghis lact must ba remenberod since 15 has an lmoxtan bearing on many operesson. Thus if ore has a tube Inli of $3011 d$ meterial and ushes to thaw tho material wh a bornez, the tube would hav to be uncesped on one ond and

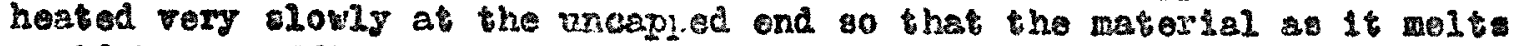
wowld havo sufflelent volume to expand into without creating axcessive

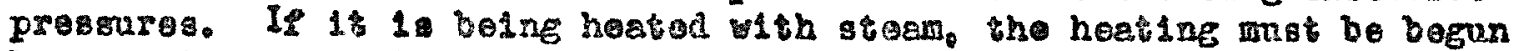
by Btirting very slowig with wark vater, making sare that the material is tiae to expand in both airsction. Faliure to observo theso precautions hes caused some sortons asoldents in the plant. There are other important 


\section{A.6.}

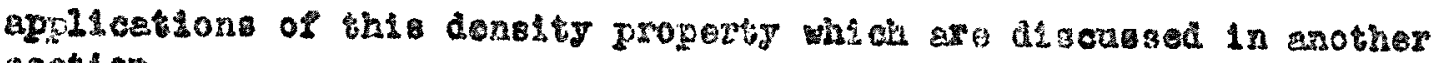
section.

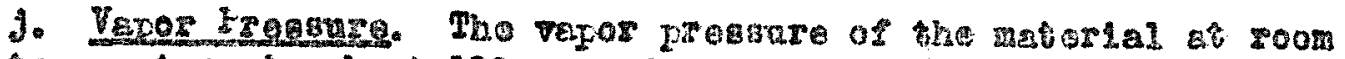

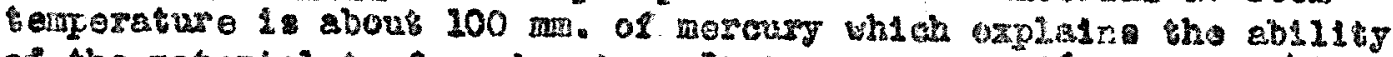
of the raserial to fome in als. If sncesas to $750 \mathrm{~mm}$ as 5400 .

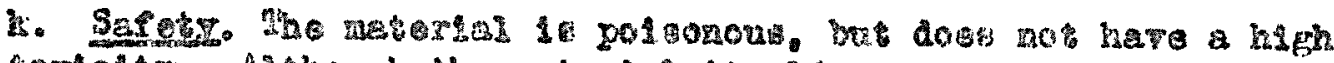

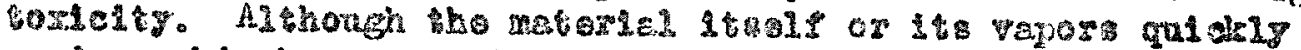

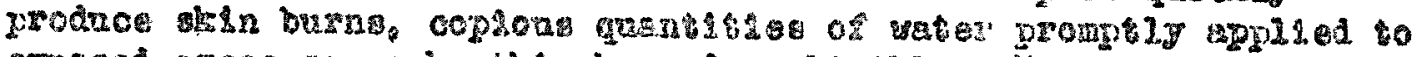
axposed arose can mairo the heraxd noglietble. Matozial papors or the moke protucal by reaction of the materts. In the molsture

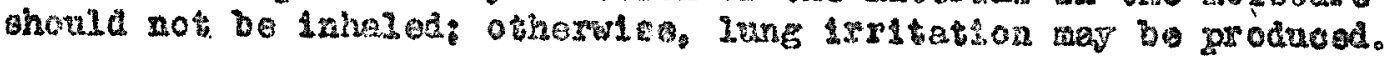

As the equlpwent hos becn tosigned and bullt to whotand the norras oparating condition of tenjerature and preasura, thoze

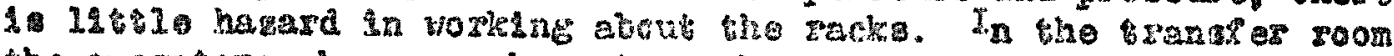
the operator, how

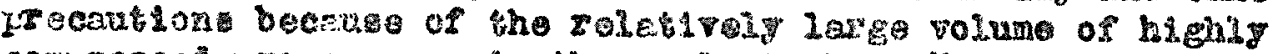

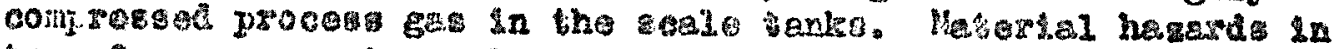

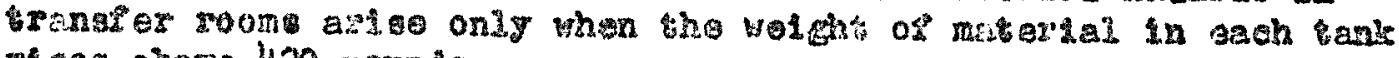
riseo above 420 pounds.

2. Ve1ves. It has deon montlozed above the the naterlal 10 rory

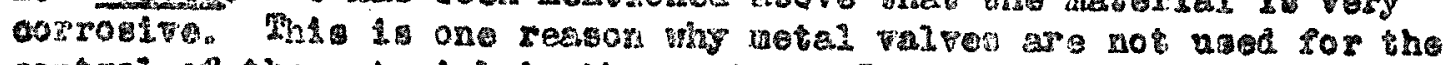

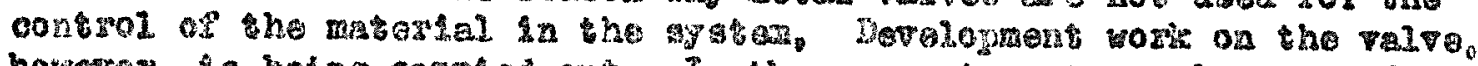

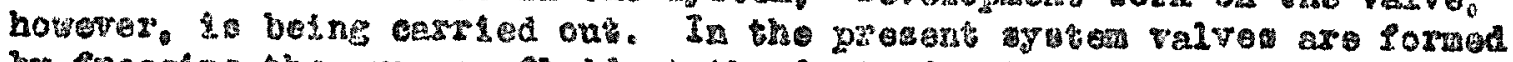

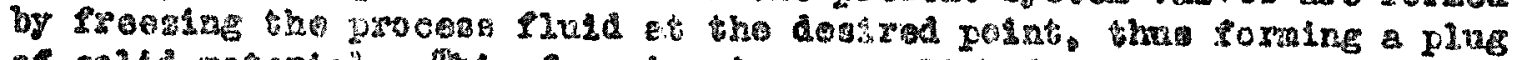

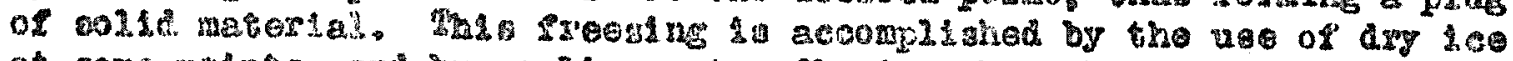

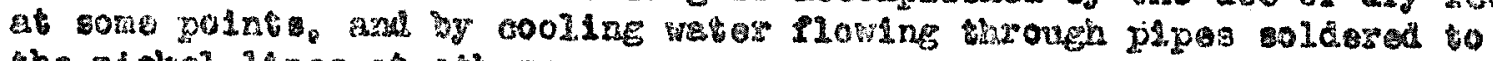
the nickel 14nes at others.

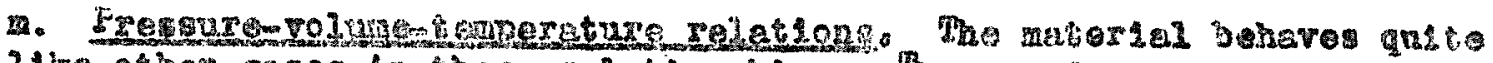

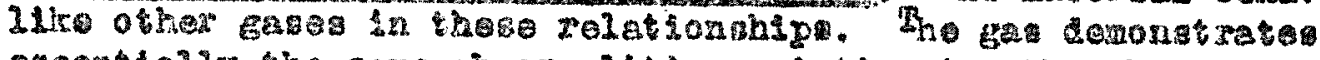

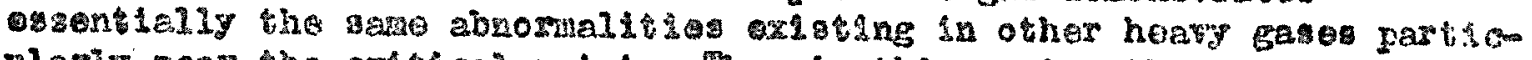

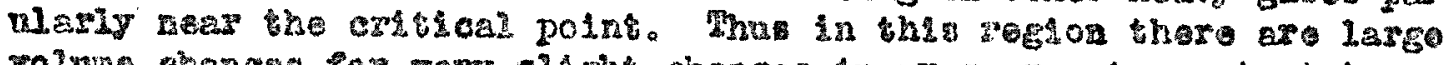

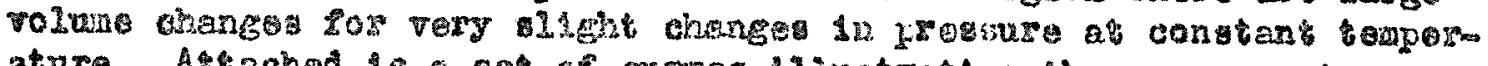

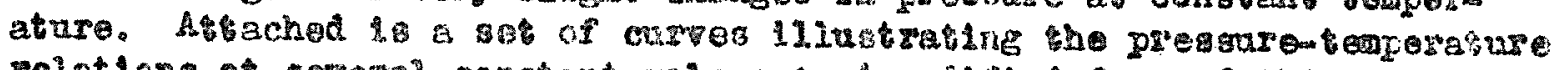

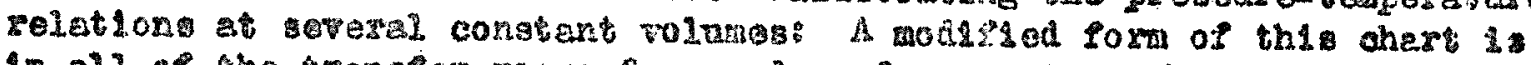
In all of the tranger soong for Joedy gasesente in working with the

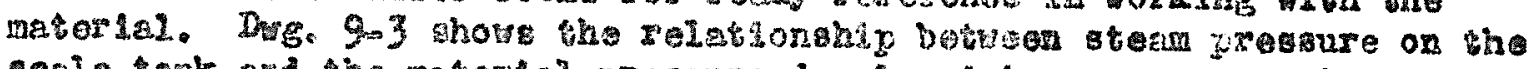
seaio tank and the metorlal presure devalopod in an average 1 zo scal tank of 77 11terg volnme. 


$$
A-7
$$

The vepor pressare of the ture solid lnareases uniformly wth temperature up to 183 melting joint at $64^{\circ} \mathrm{C}$ and the 11 quid

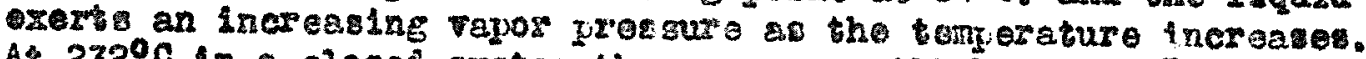
At $232^{\circ} \mathrm{C}$ in a clomed sgsten the preasure w111 bo about 700 yound: per square inch. Abore that enverature, the ontre gyoten becomes a single Inid state and a furthor rac in temporature merely increases tho pressure of the $2 y$ tom, roughly is conformity wh

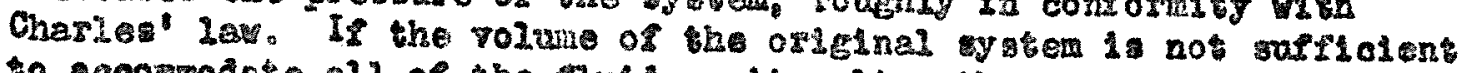

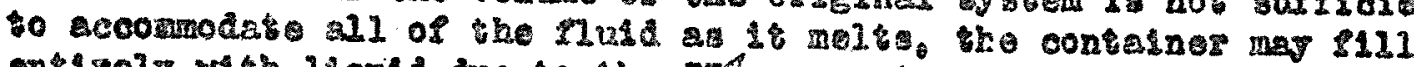

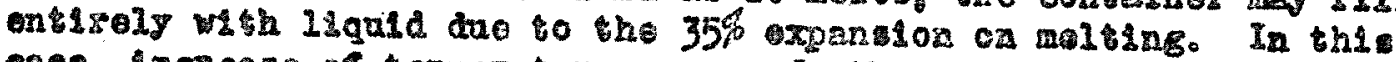
case. Ineraese of temperature ceunos further 11 quid exponalon and

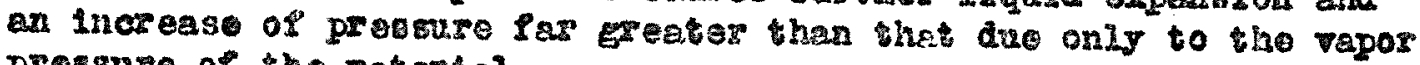
prosinge of the matersal.

Frowerty of expansibility and rapid change of rolum wh yresinre has a difect benring on plant oparatsone. The matcrial is cherged to a tank on a sealos in rolghed amounts and heater whth atoen of

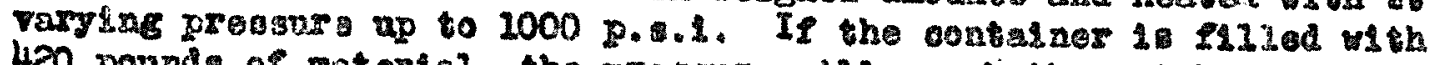
420 pound of materta?. the presture will zeach the nolghborhood of 2500 pound per square Ineth then the tank is hevtod uth 1000 pounds

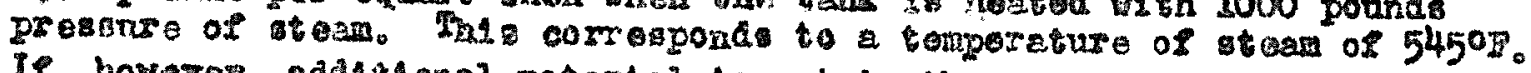
If. howorex, addithonal material 18 pus in the acalo tanis the prosmure can riso to molh heh relues when heated with 1000 ponnds stoam.

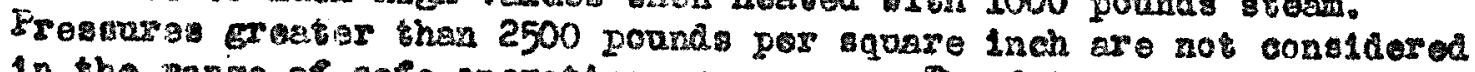
In the range of saso oporestre yrassurea. Do date for matorlal

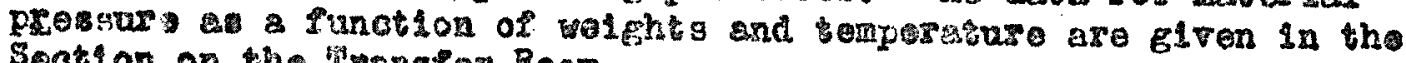
Sootion on the franger Room.

n. Eropertios of "Frogh Afs". Another matertal unod in the procos

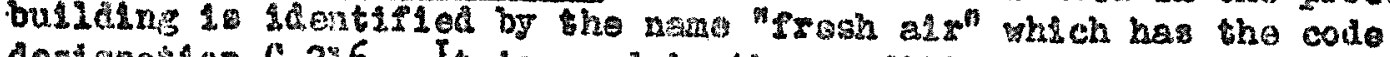

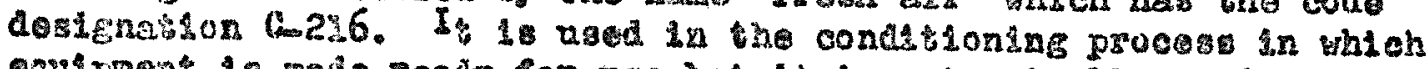

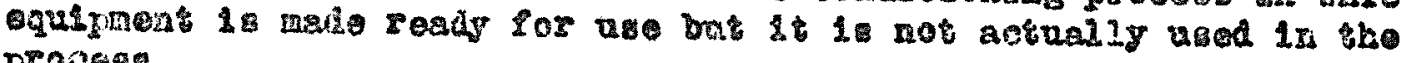
proses:

Frogh alr 18 supj 110 to the plant in largo nidkel cylinder at a proseure of about 40 pound yer aquare sneh. If has a rexy ditinctive and Inotrating odo and can bo desected in amall anount.

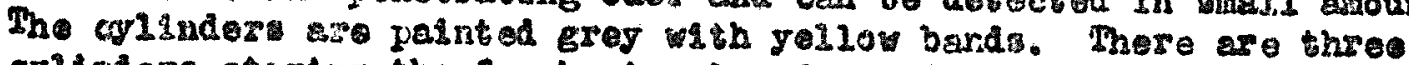
cyliriters serting the srech alz pleced outaldo of the procen bullding on the west ida. The gat is piped in through copper tubing to the vardous transfe: rooms Irom whl ah 14 can bo diseributed further.

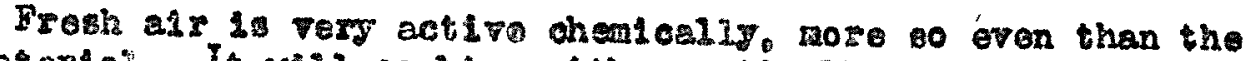
procos meterlai. It will combin with practicalis all matortale vigoro ounly. Conseguentis. It 18 neceosexy 80 oliminato al. leak in tho

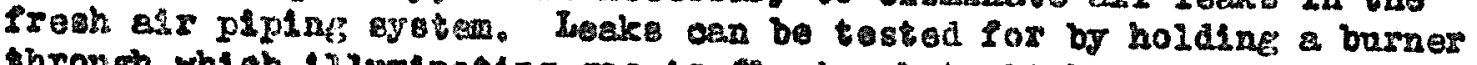
Chrovgh which 12luminating eas is flouing but which ia not lenttod noar tho point in question. Fron a amali loak will uwualiy causo tho burner 
$=8$

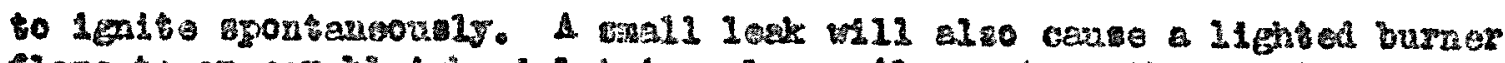

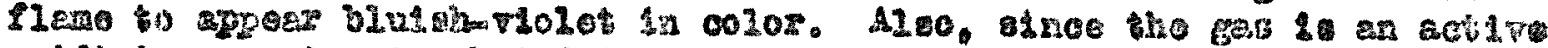

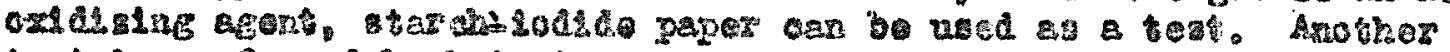

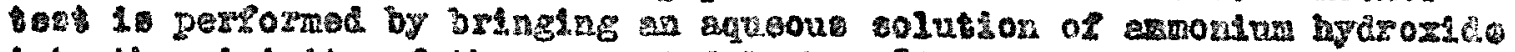

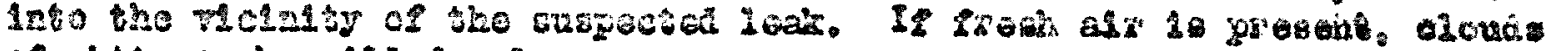
of wht te moko rill dowelop.

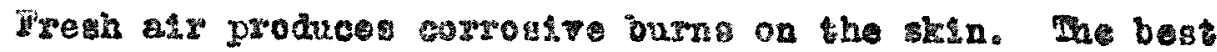
2 enody is to apply lasgo grantsties of wescz. It w11 also afreot

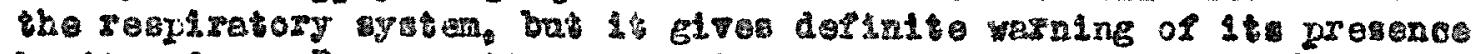

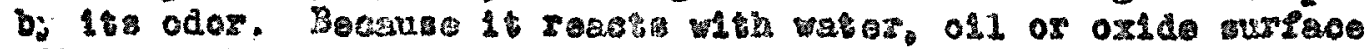

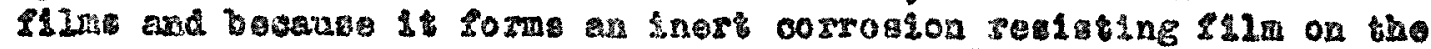

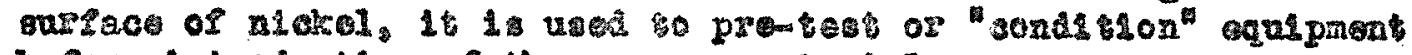
berore introduction of the prosers natortal.

\section{Ino Elan of the Watar Sato}

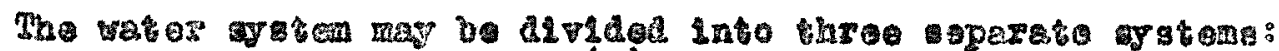

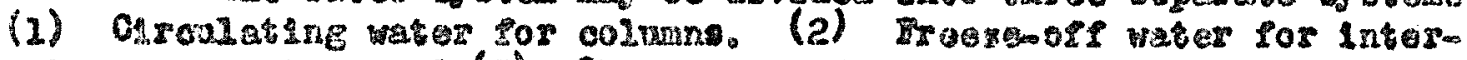

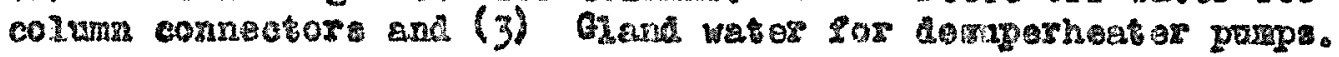

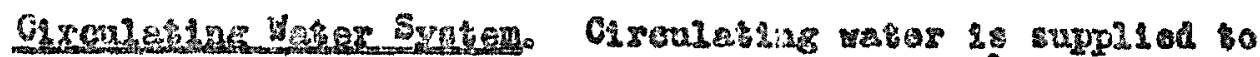

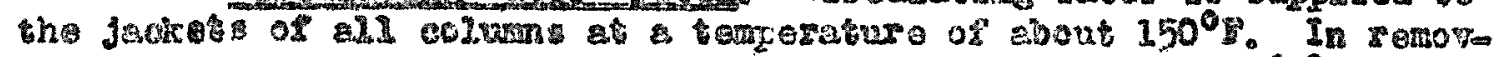

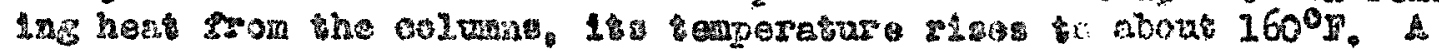

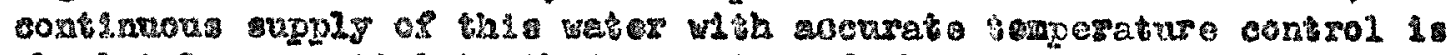

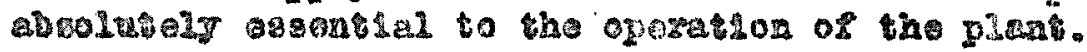

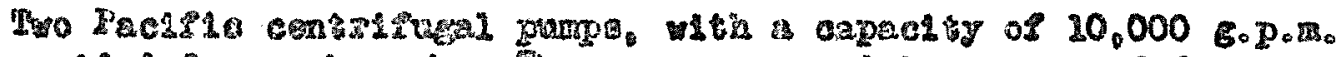
uach axe proviad por ach zank.

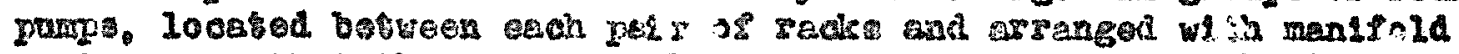

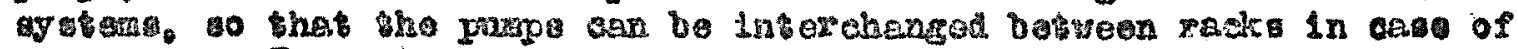

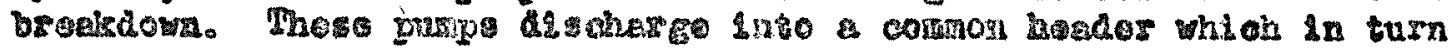

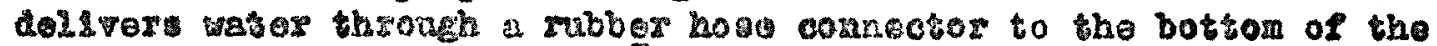

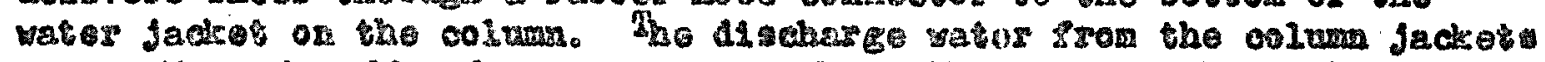

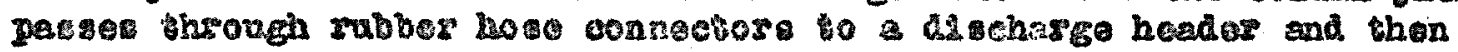

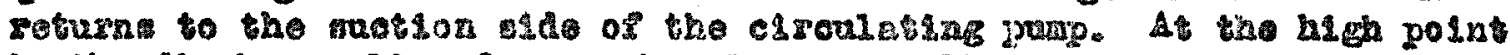

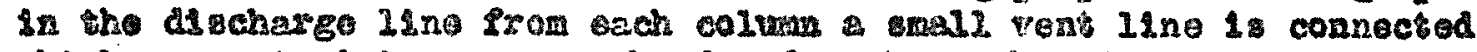
which comect laso a conmon header for the rads and then vent trioucto

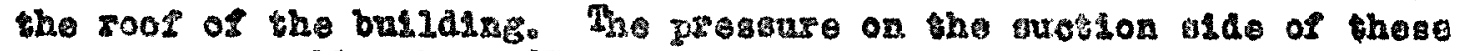

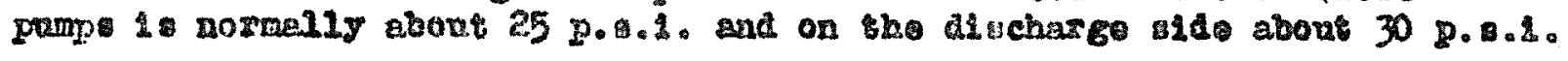

Since the terpereture in a olosed olrculating bygtem wond

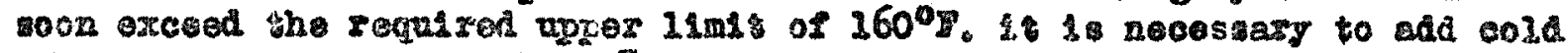

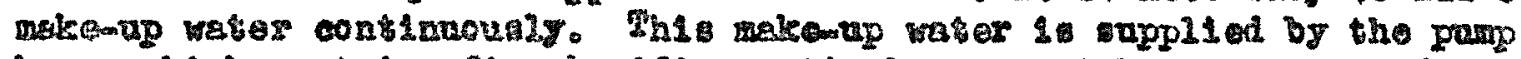

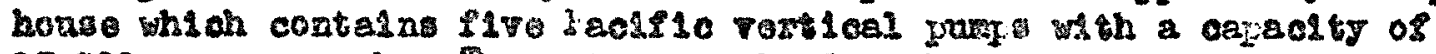

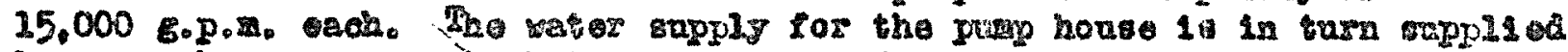

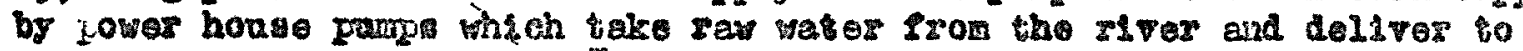

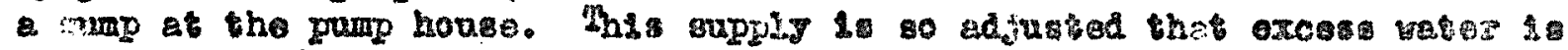

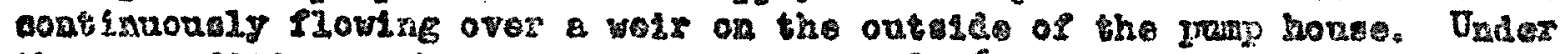

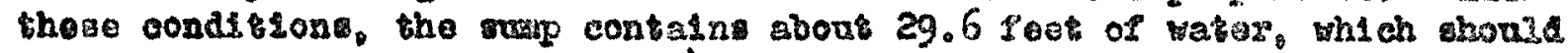

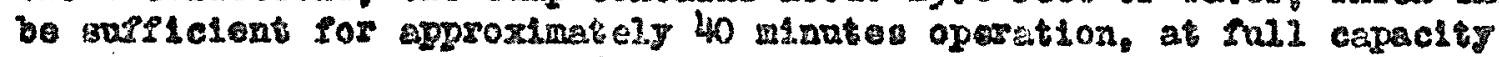

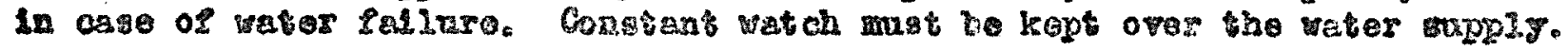




$$
A .90
$$

The discharge Irom the 15,000 g.g.a. Vort10al puaps goes into a header which passes underground to the process batlding and then branohes off to the indifidual racke. The raw make up water reeds through a control valve on the euction elde of the c1 roulating water system. This control ralre is operated by a temperature recorder an controller just out ide the transfer room. The controller is of to matntaln a temperature in the suction side of the clrculatine vater syeten of $150^{\circ} \mathrm{F}$. If the temperature rlees, the ralve opens and adnits more maken up water. If the temperature

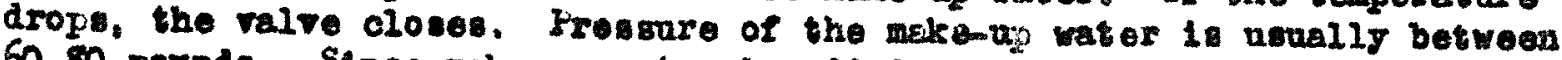
60.80 pounds. Sinoe make-up water is added continuonsly it is neceseary to rent vater from the syotem continuously. A line branches off the dis charge header at the top of the racke on the east elde of the batiding and conduots the water to the sewer.

The hose connecting Individual column to the Inlet and out let header have crused troublo in the past by allpgine of the pipe during ervice. Since 14 is imperetive to keop vater in the olrculating sotem at a.1 costs; a secial operating procodure is included in another section to cover thl omergeney. In general. 14 consioto in adjusting the tempora bure controllex so that the make-up vater valve se wide open, thas supplyins adequate water to the reck in splte of the leak at the hose connector. After this, the steam 18 shut off and after the raok has cooled down, the clrculating pump axe hut off and the faulty hose repleced. If the rack contaln material, the column should be frosen off at the bottom of the rack before loworing the water temperature.

If the mpply of make-up watior falls, fhe clsculating vater w12 heat up to the boliling point in about two or throe minutes and will tarn completely Into otean if service is not resumed. $I_{n}$ the colume there are sereral ellvermoldered jolnts in the eopper tube. These joint are cascoptible to fallare due to ennealing of the work herdened jolnt when hested by the 1000 pound ateem which flowe through the Inner nlekel plpe and when subjected to process preseure of 1500 p.s.1. A $A_{1}$ to the copfor tabe 1 teels w111 anneal and belng under otres due to differential expansion of the two wetels, may fall. In Dug. 9.4

4 schemat10 diegram of the circolating water system is shown

Ireereoef Water Srstem Water for th c1rculating system 18 rivor water treated with Calgon. River water 1 tself is not satiafactory for use as freeso-off water since it contalns seclment which vould plug up the mall valves and small diameter copper pipes soldered to the intercolumn connector:. Consequentiy, a separete water eystem 1s usod. Water 18 pumped from a vell to the vater trestment plant where it is glven a coagulation and oettling preatment. Th1 woll water is considered to be botter than the raw river water for this purpese. Tho water is then

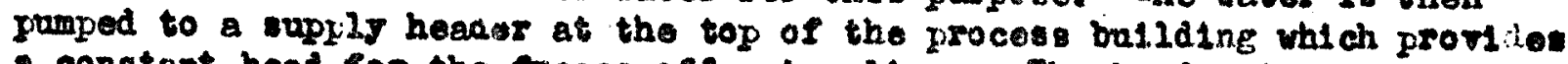
a constant head for the freeze-off water 11nes. Tho header 1: closed so that a preserure at the bottom of the rack 19 doveloped of about 80 pounds per square inch by means of an alr prap. An auxillary supily oontrolled by a float ralro is avallable so tha if the voll vater oupply falls, the head can be malntalned by the automatic introduction of clig vater into the system. It 1 in Imerat 1 that freosomost vator be avaliablo at all times. 
-

0

-

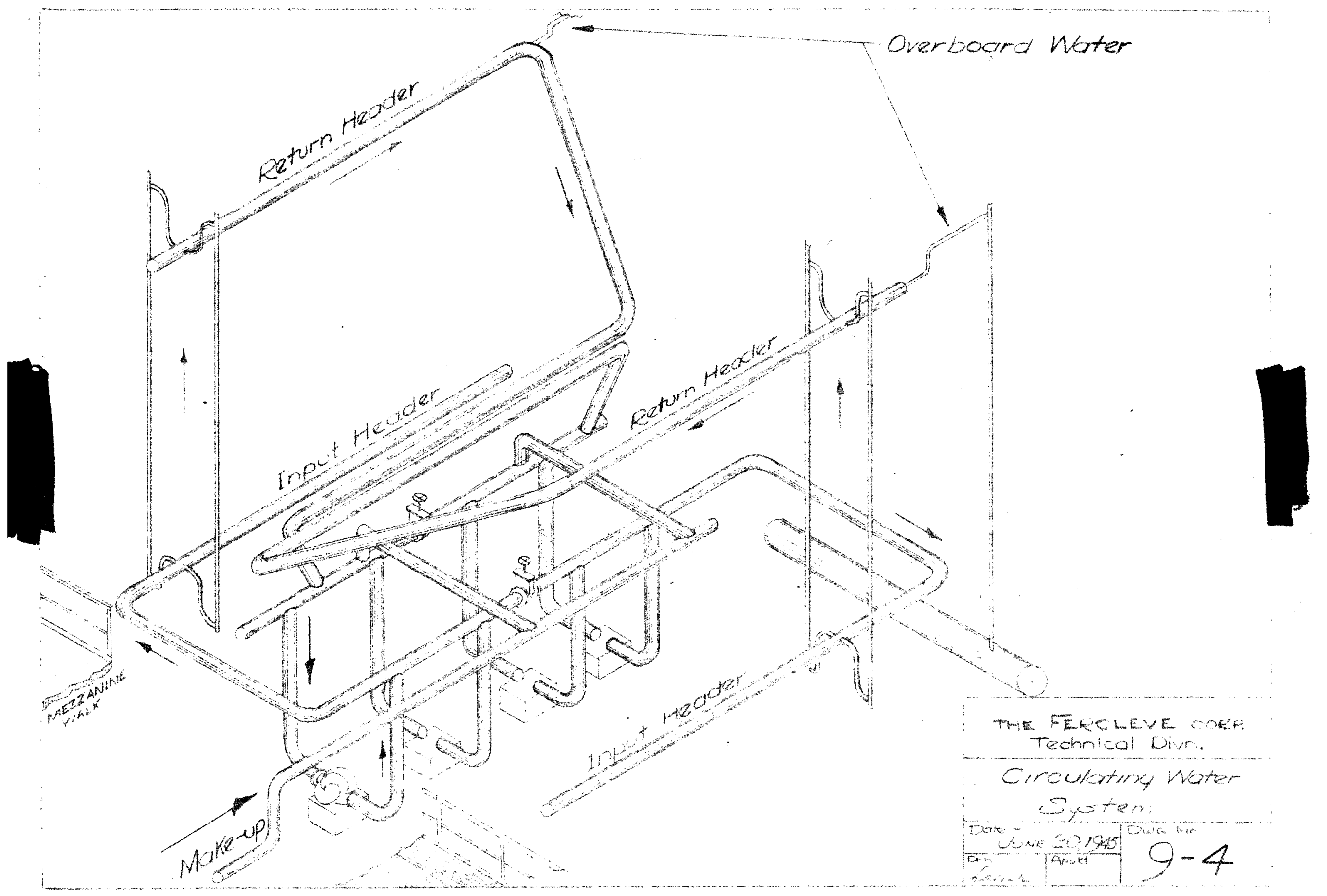


$A-10$

The ouply of water to $t$ e ereage-oft header is adjueted so that her La a constant overflov. Branches fron this header lead to the Individual racks, where tho again divide into a supgly for the top and bottom of the rack. T $r$ of the four water header can be controlled by a solenold valro, operated by a timer or togele autches located in the control resm. The colenold control is provided In connection with the antometic ramoval of product. The water ilnes may bo operated by manually controllod valves on the rack. The water. after pasine through the copjer Irecze-off I1nos goes to the ever.

Gland Weter for Deruperheafor Inmpe. Oland water in required in connection With the operation of the desuperheater pomps wish are described under the section on the seam system. It va originally Intended to take water Irom the water treatmont plant and jass it through lermatlt filtrebion tank before upplying to the mall gland pamp which would in turn puin water to the glende of the desuperheater punpo. The Formutit tank are the tank located in the southwest corner of the process bullaing. The sy atem now in use, howerer, takes condensate rom the low prassure steam and uses it as the gland water in the large pumy. Th1 water then Plow to a tank d1rectly above tho dosuperheatine prope

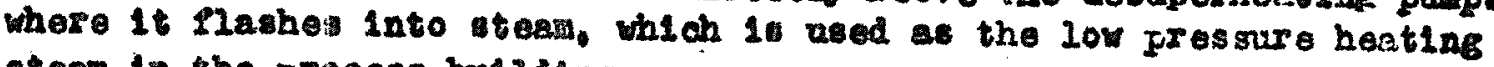
stean in the procen batiding.

\section{Iyan of the 5 tean Syetem}

Steam is oupplied to the procese bullaing from the power

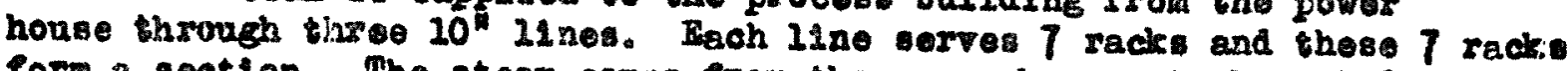
form section. The stean cones Irom the power housa at about 1325 pounte

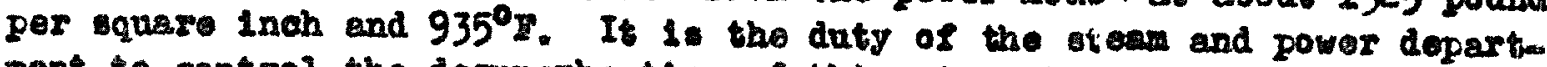
ment to control the deruperheating of this stean to our frocess requireinent

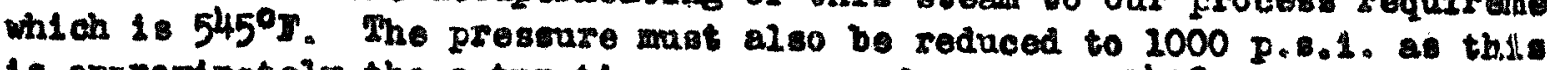
1. approximately the saturation jressure of water at $545^{\circ}$.

Desurerhoating. Desuperhoating 18 accomplished by the Injoption of water condensete from the Low P.B.1. oteam used in the column Into the eteam at four different noszlen. One nozele is located fust outelde the process bullding, one just inslde the ballding in the couth end and one along the weat wall near liack 21. Theae three nozsle are controlled by one controller on the stean control board and constltute the inftial desuperheating system stage. The fourth nozzle, whiob 1 located juet beyond tho steam control board, constitutes the final desuperheater.

Water for the demperheating is injected into the oteam from three desuyerhenter prups located at the south end of the bullding. These pumpo oupjly the condonsate for injection at a pressure in the nelghborhood of 1500 pounds per quere inch. 


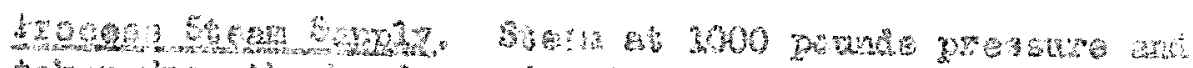

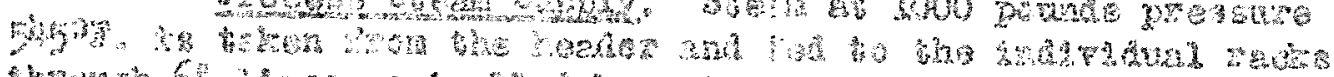

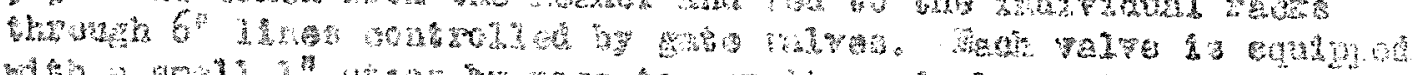

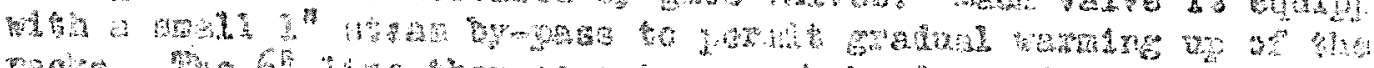

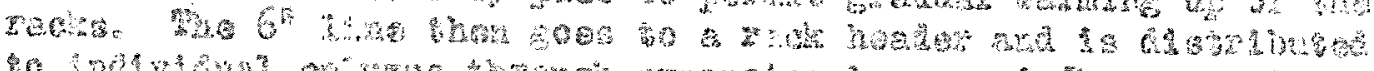

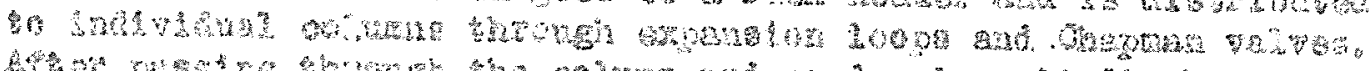

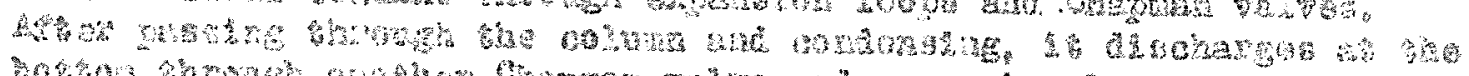

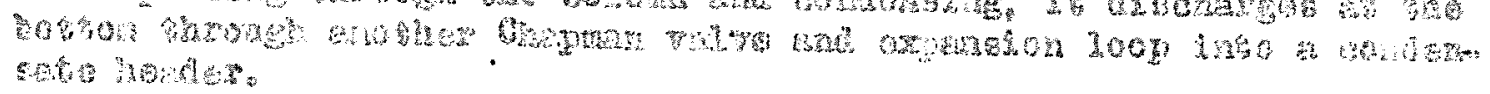

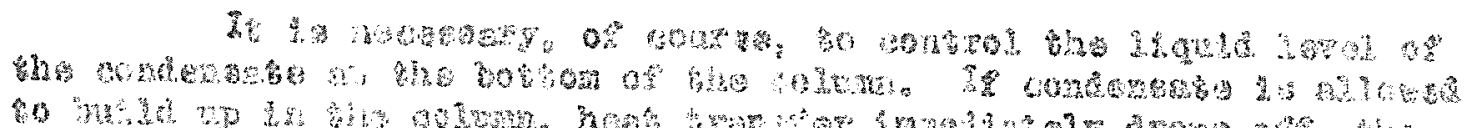

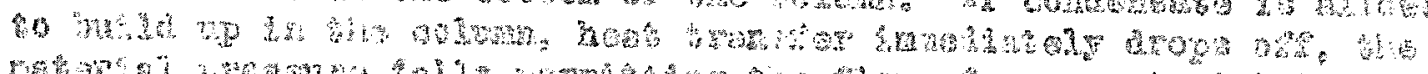

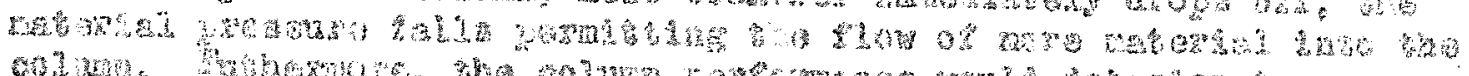

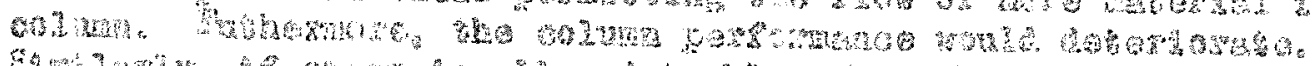

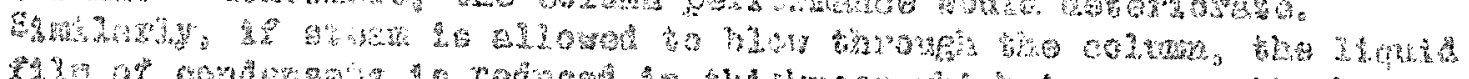

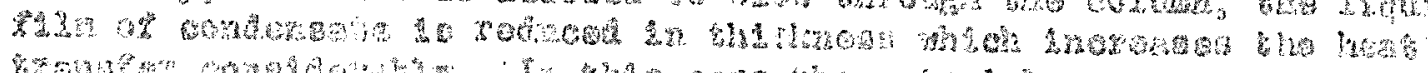

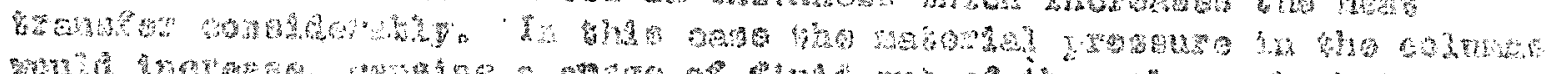

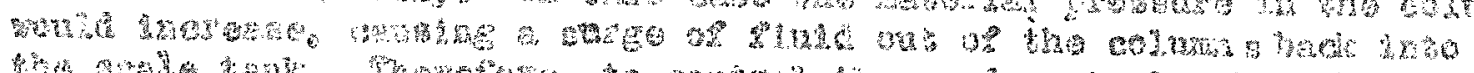

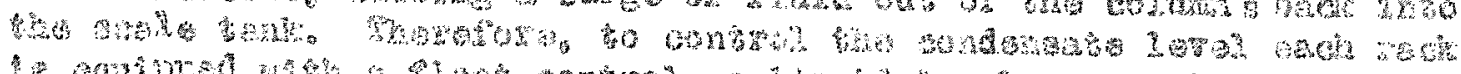

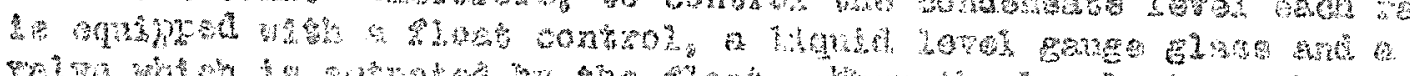

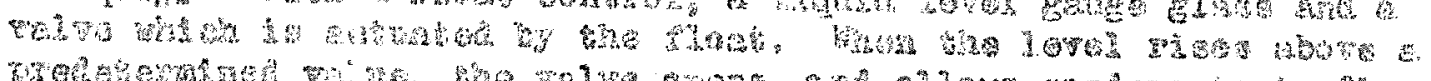

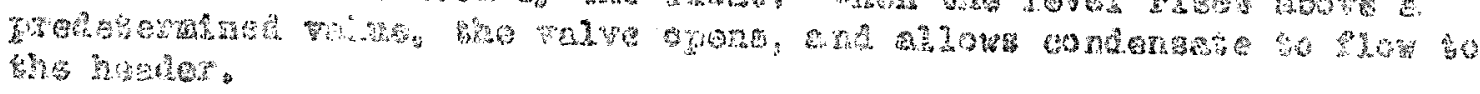

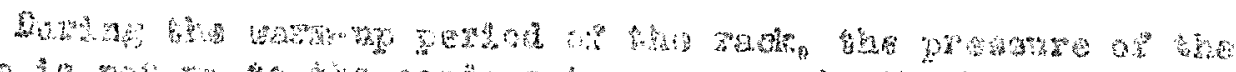

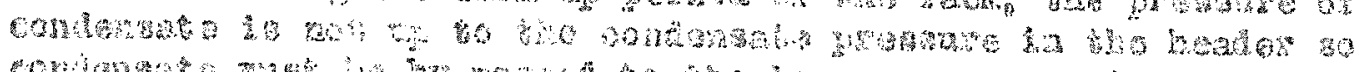

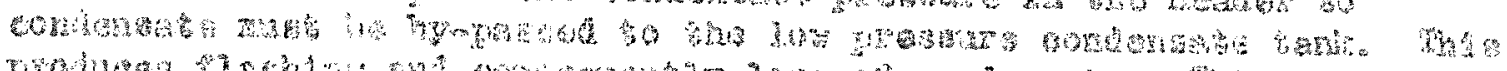
2.

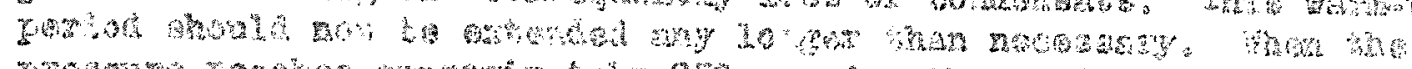

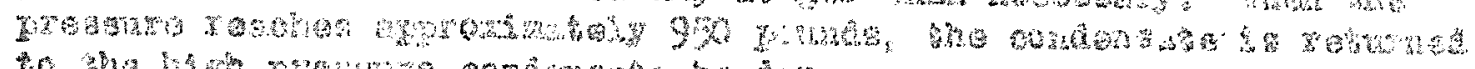

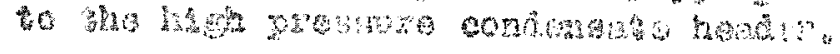

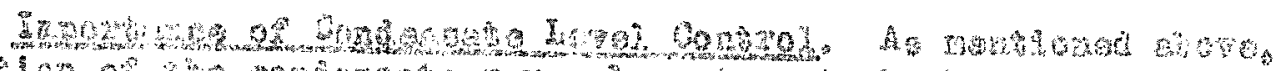

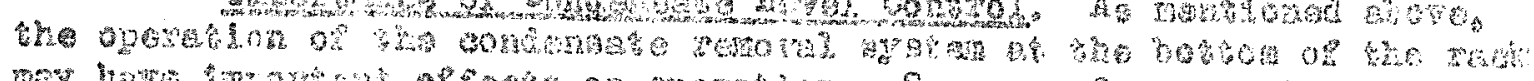

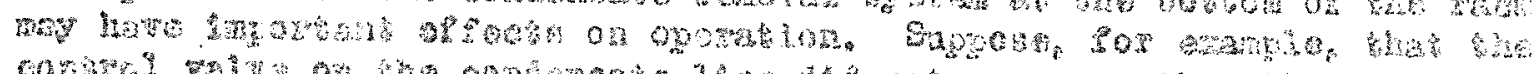

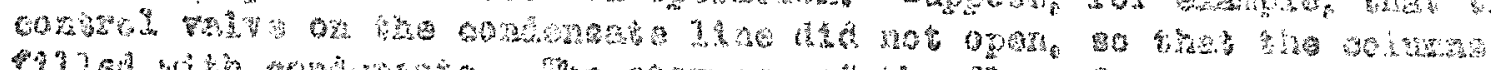

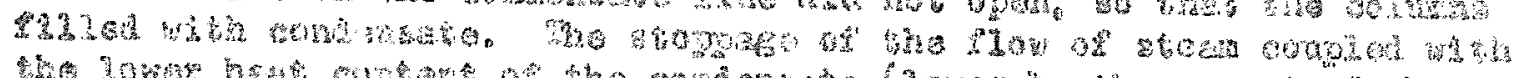

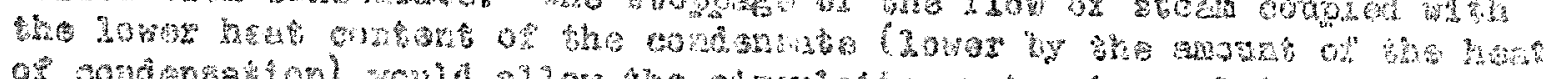

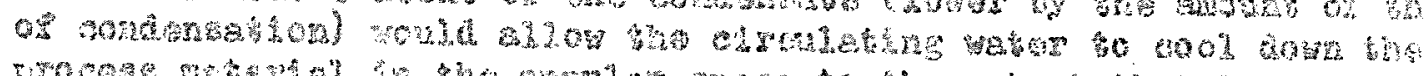

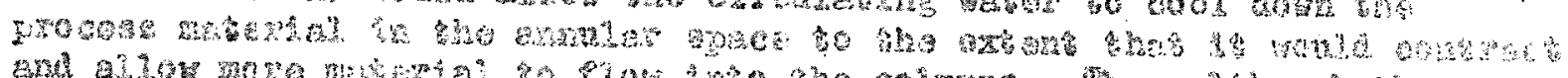

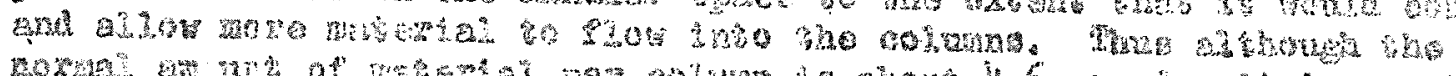

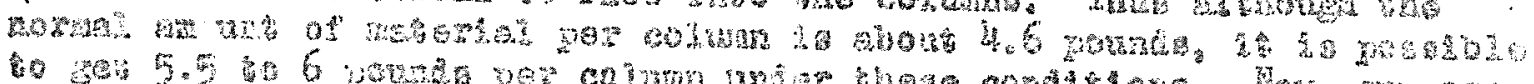

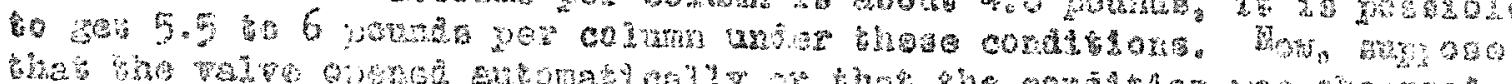

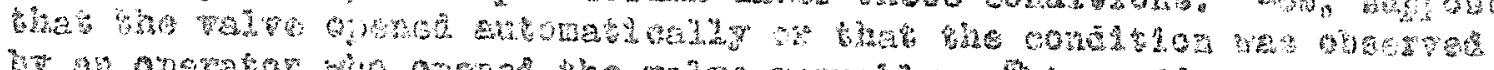

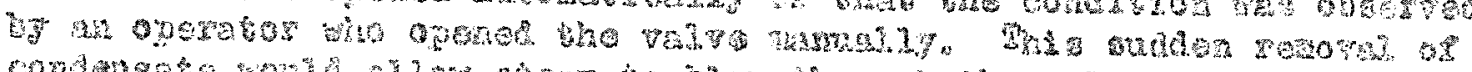

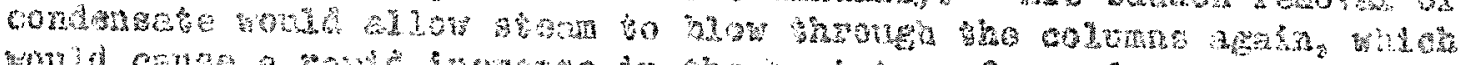

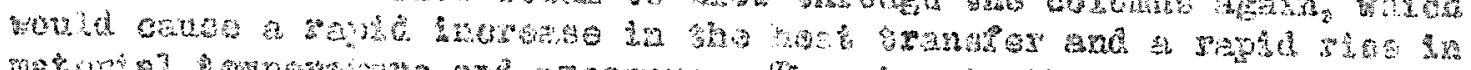
metural.

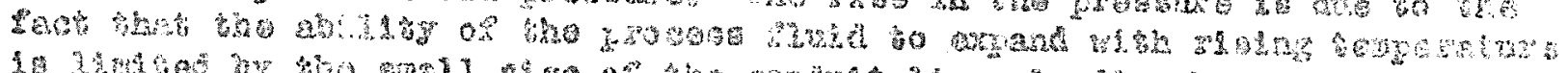
20 INH

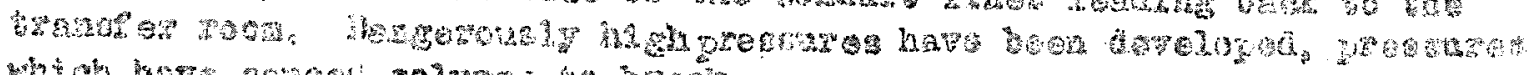

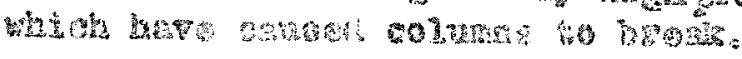




$$
A=12
$$

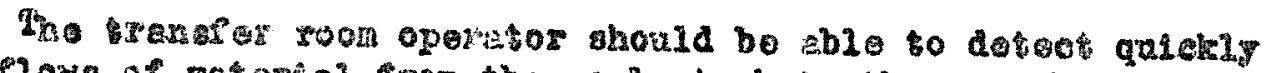

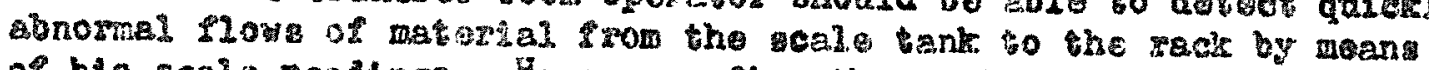

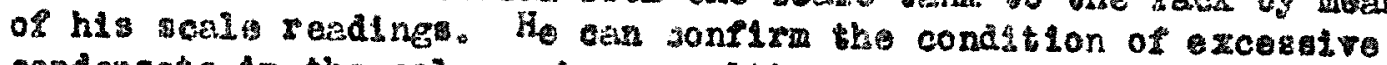

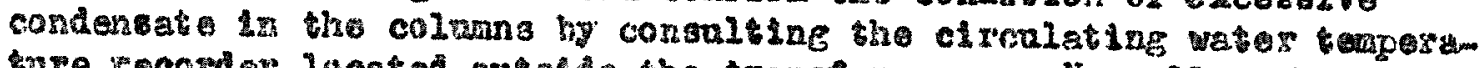
ture zocorder lucatod outside the transer room. Normally the anyora-

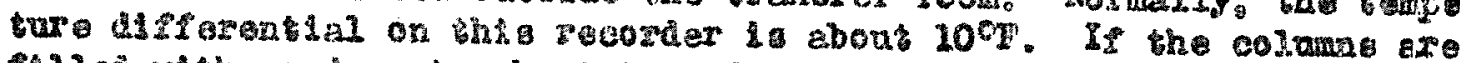

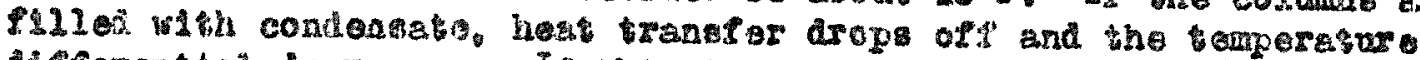

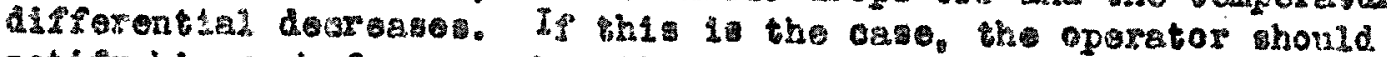
notify ha rack foremen who w1l arrange to dratn tho condenseto srom the

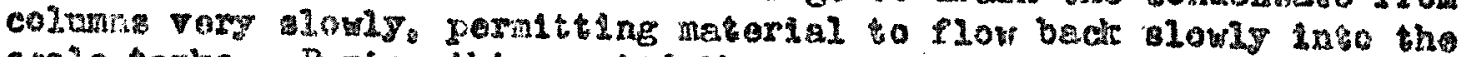

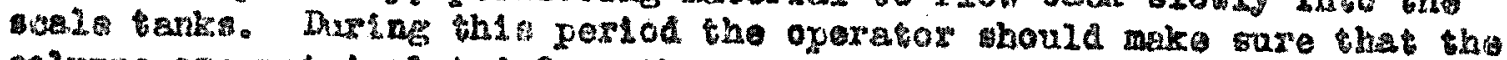

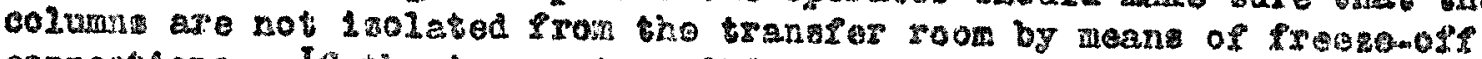
connestion. If tho temperature disferential has not decteased and ip

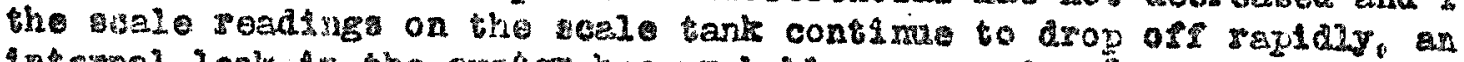

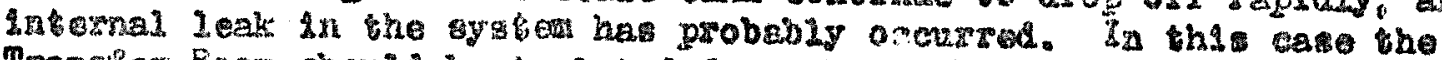

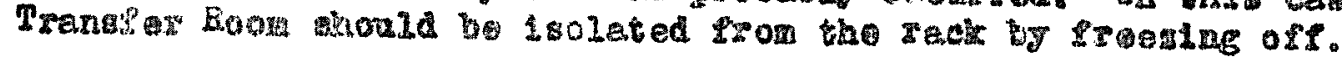

5.

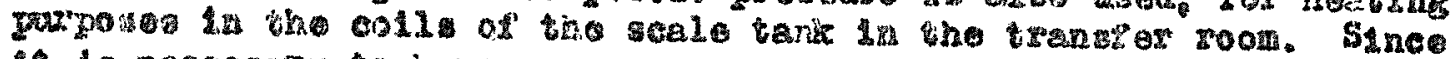

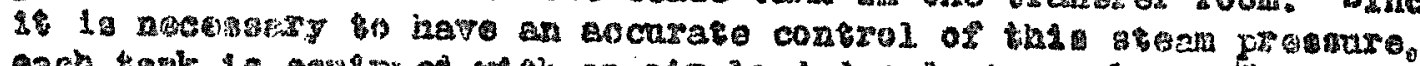

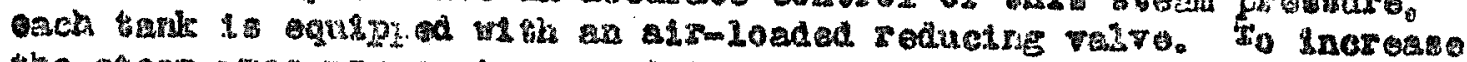

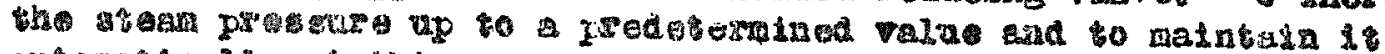

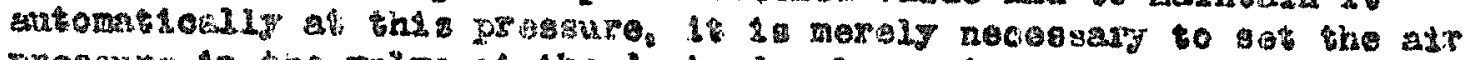

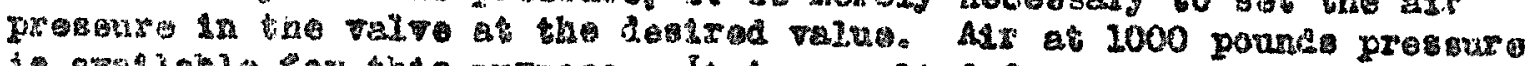

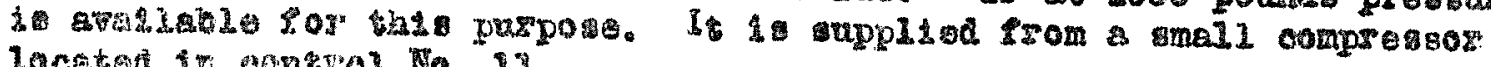

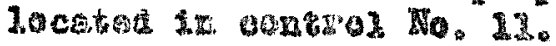

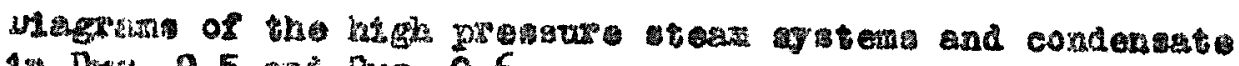

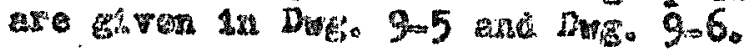

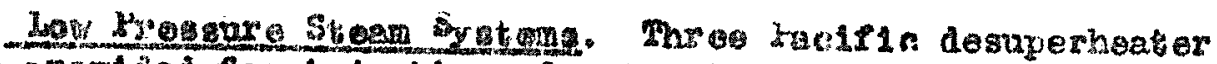

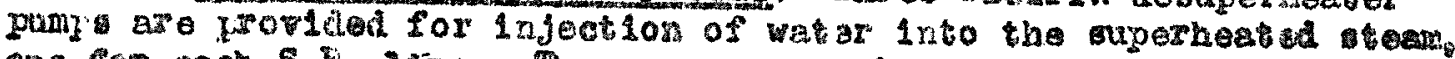

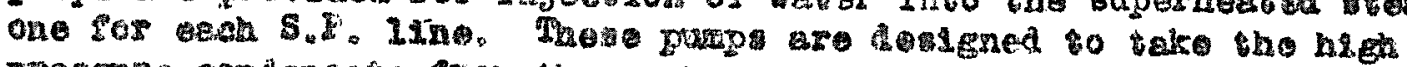

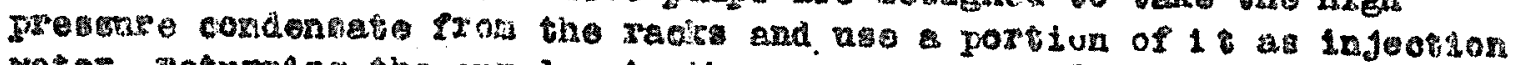

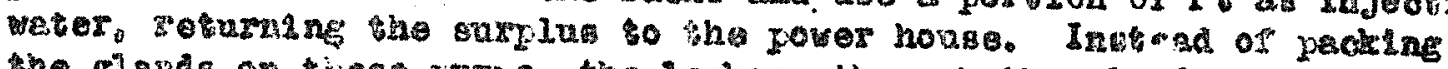

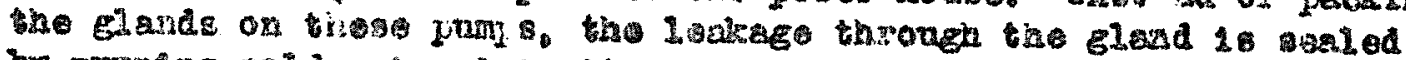
by premping cold water In\&o $2 t$.

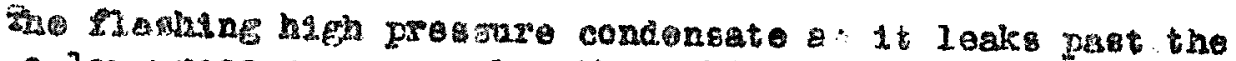

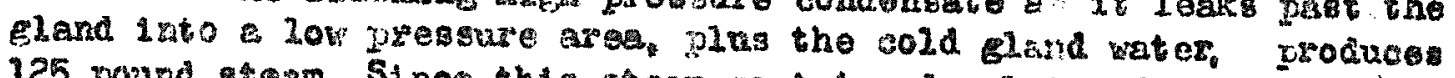
125 pound etean. Since this theas contelno droplots of waser. a

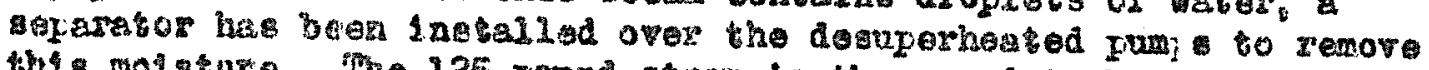

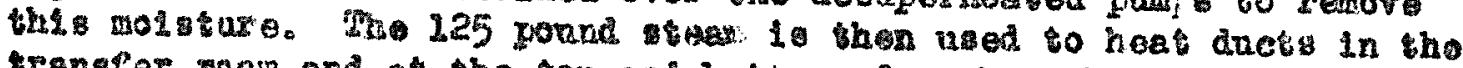
sranelar roon and at the top and botton of euch rack. After boing dicherged by a trap. the cordensate from the 125 pound gycten is aollectad in the condenwate lamp tank in the soukh ond of the buildine and purped back to the power hone. 


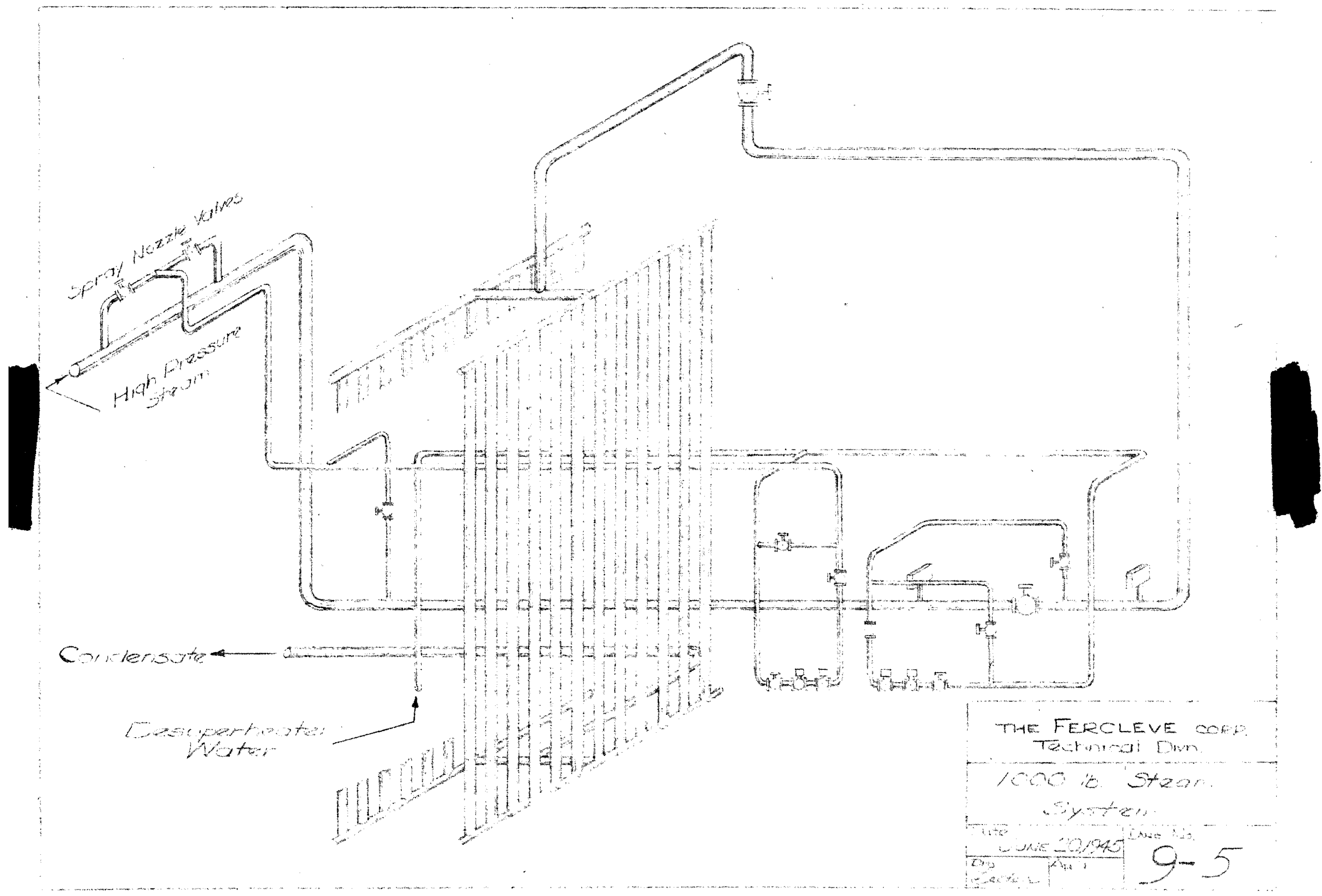




$$
\text { 1. } 17 .
$$

Conderigete Trexe. As grosent rang of the trays on the 125 pound

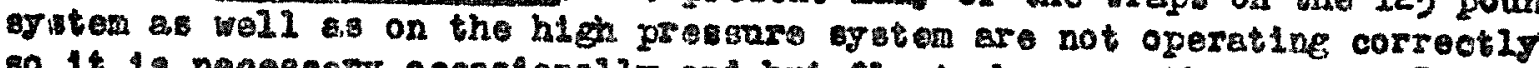

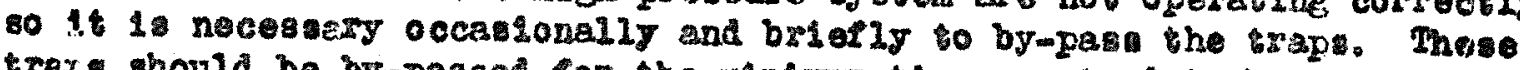

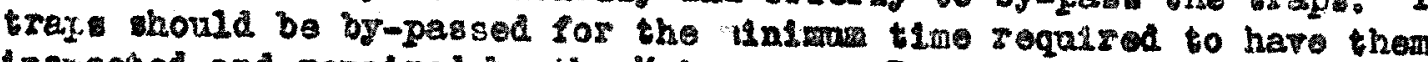
infrocted and repalred by the Malr onance Depertment. ince Prequentiy

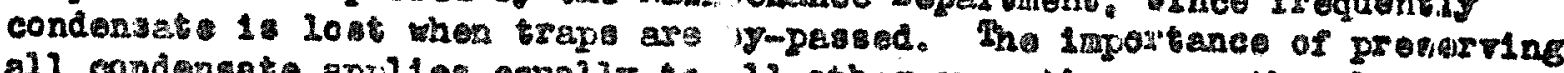
all condensate applien oqualiy to 11 other orerations a the plant vas destened to return essentially ell of the condensate to the power house. Beficlont operation of the power honse is dependent upon this fact.

5it Stcan. 125 pound stoan is also used to heet tho high sompore

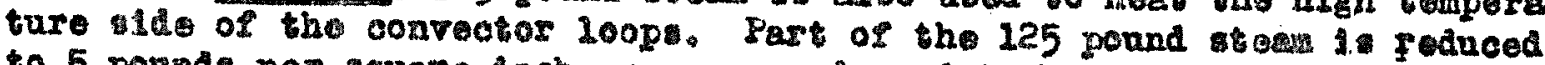
to 5 ponnds per square Inoh $\mathrm{gres}$ sure and used to hext the lor prescure conveotor ripes and the condutt loading from the trangfer soout to the racks. Condenwe eros the 5 pound syaten is colloned with the 125 pound
steen condengate.

\section{Fuan of tho dis. Syatan.}

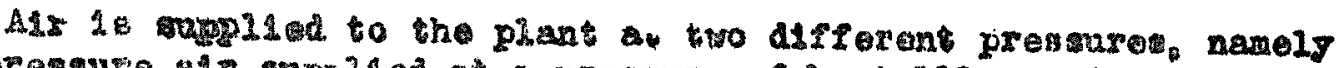

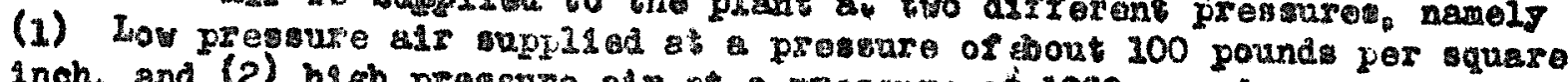
Inch, and (2) hdgh prosiure als a gregare of 1,000 pounde.

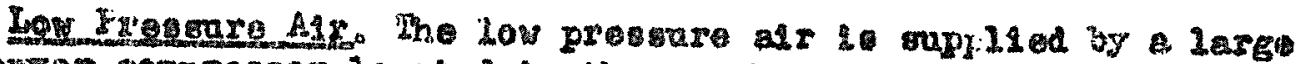
Gardnermburar compressor locatod in the goutheas corner of tho main building. There if alao an energenep imgersollmand comprossor looated.

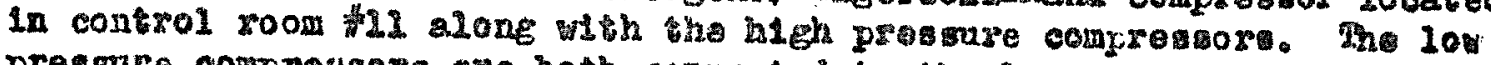
presture conpronisors both connacted to the low preogure hoacer which rune alune the top of the east alle of the naln building. tho alr which

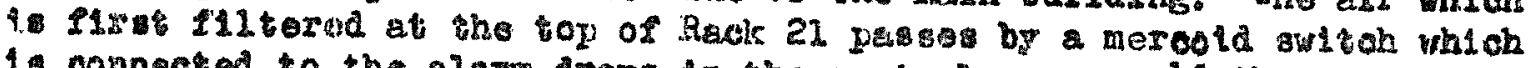
1. connected to the alarm drop in the control rooms. If the preanure

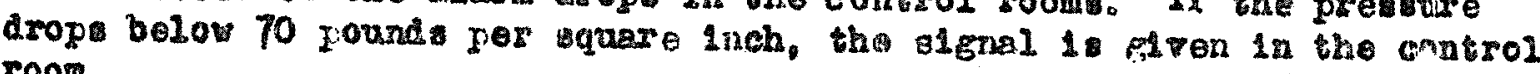
room.

The main header runo the length of tho bullaling on the sast

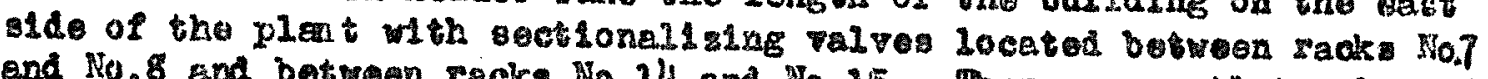
and No.8 and botwoen racks No.14 and No.15. Thero are outLe raivos zor

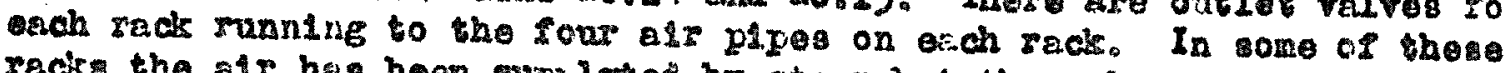
rack the alr has boen mupylated by steam but the ralves aro burned off manuelily at the header on these racks. At the north end of tho bullding the 11ro runs across to the west sldo of the building to the trengfer rook hacder.

At the ond of the bullding where the rumbering of rack bogina 1. Located the transter poom heeder valro. The line then foturn along the nezanine laval whtoum lines with ralves leading to each patr of rackn. Azother westioning valve is located botroen trenafor rooms

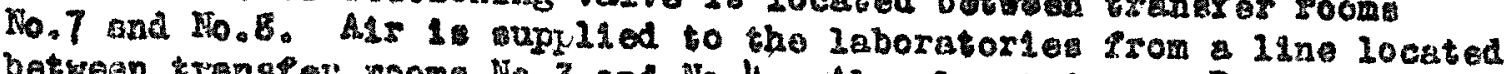
betrean trangler room $\mathrm{HO}_{0} 3$ and No.4. Al wo looated nar Rack No.1 1 .

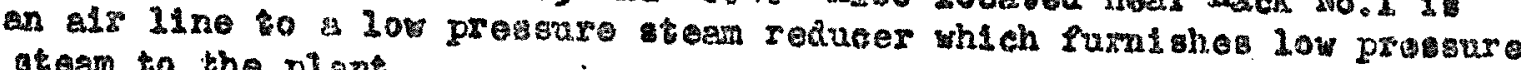
otoan to the plant. 


$$
-14=
$$

0. the two 12 nes per raek in tho transer room header, one in Ine

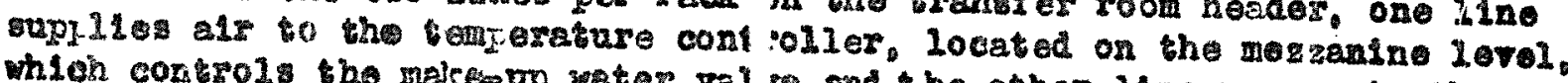
whien controls the malcesp wer val and the other line pesses to tho

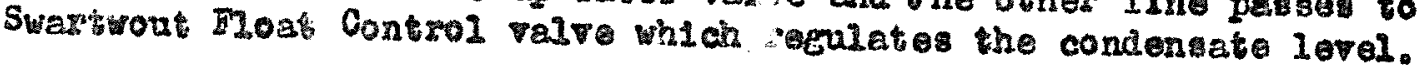

Oro other use of the low I regure atr $1 \mathrm{~s}$ to reduce the 125 pound 2tean to a rastable stesm jusesure is the tranefer roon for hoating the

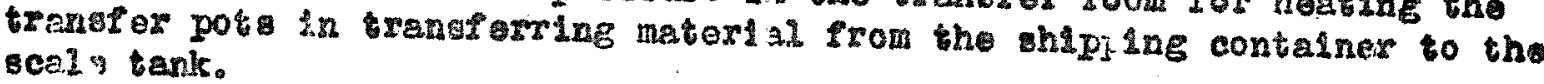

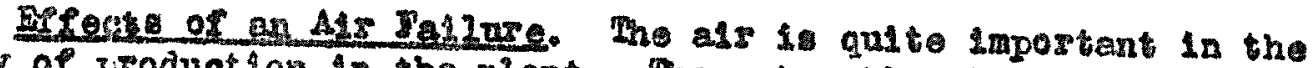
continulty of jroduction in the plant. The automatle alfooperated ralve

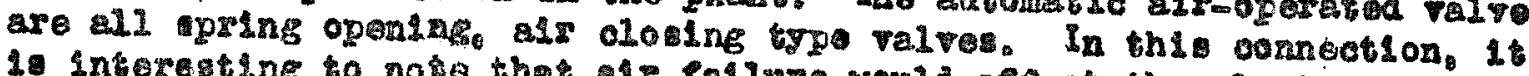
Io interegting to noto thet als fallure would affoct the plant in the

(1) Tho deruperheating wator yegulator would open and $1100 d$

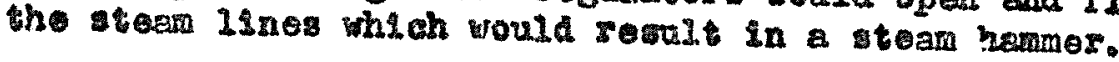

(2) The temperature controlles on the arculating water lalot vould open and cool. down any rack operating.

(3) The valvo reducine tho team pseasare to $125 \mathrm{~g} .1 .2$. would opon, allowing stom at 1000 pound p preasure to

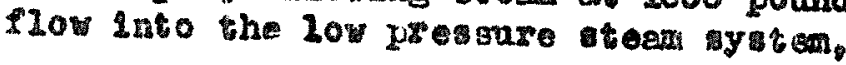

(4) The oondonsace return ralvo would open and blow at ean beots to the power house. $9-7$ and $9-8$.

The layout of the Low preasure alr wotem 1: given ia Drgn.

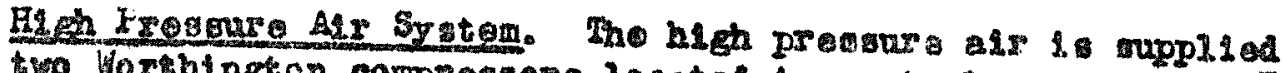
by one of two Worthingtion comprearor located in control room Noj1. Tho ats 1 psesed shrough a water cooled nnit inco a roservolr and frum thence 18 passes into the 1000 pound heeder to the transfor rooms. There aro two esctionalining raipes locesed on the header, ono locat ed in control room and the othes loceted in control room 3 . Thare 10 also a valve on an open ilne at the ond of tho header at the nosth ond of the baliding.

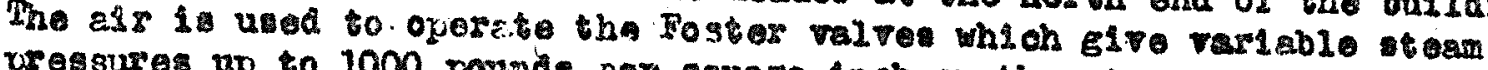
juessures up to 1000 gorids per square inch on the torage tanks.

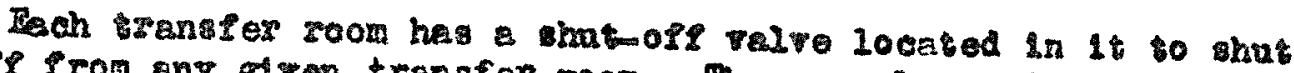
the aly off Irom ang giren transfer room. The are looated in tho cranse or room except in the tolizoting chese

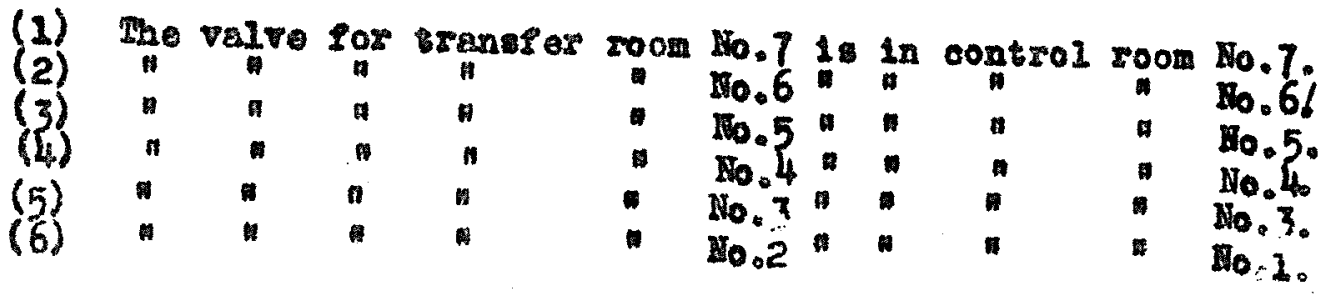




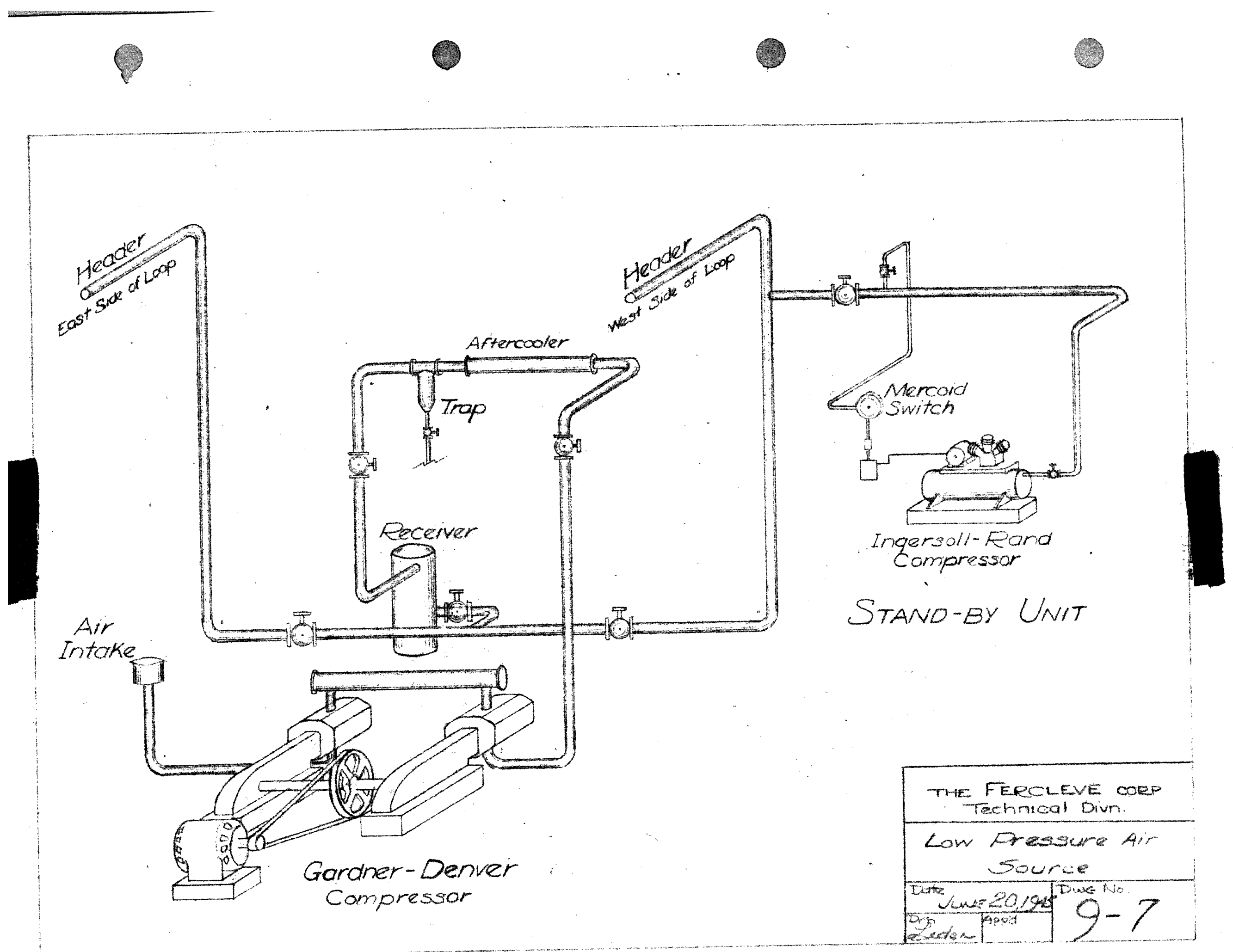



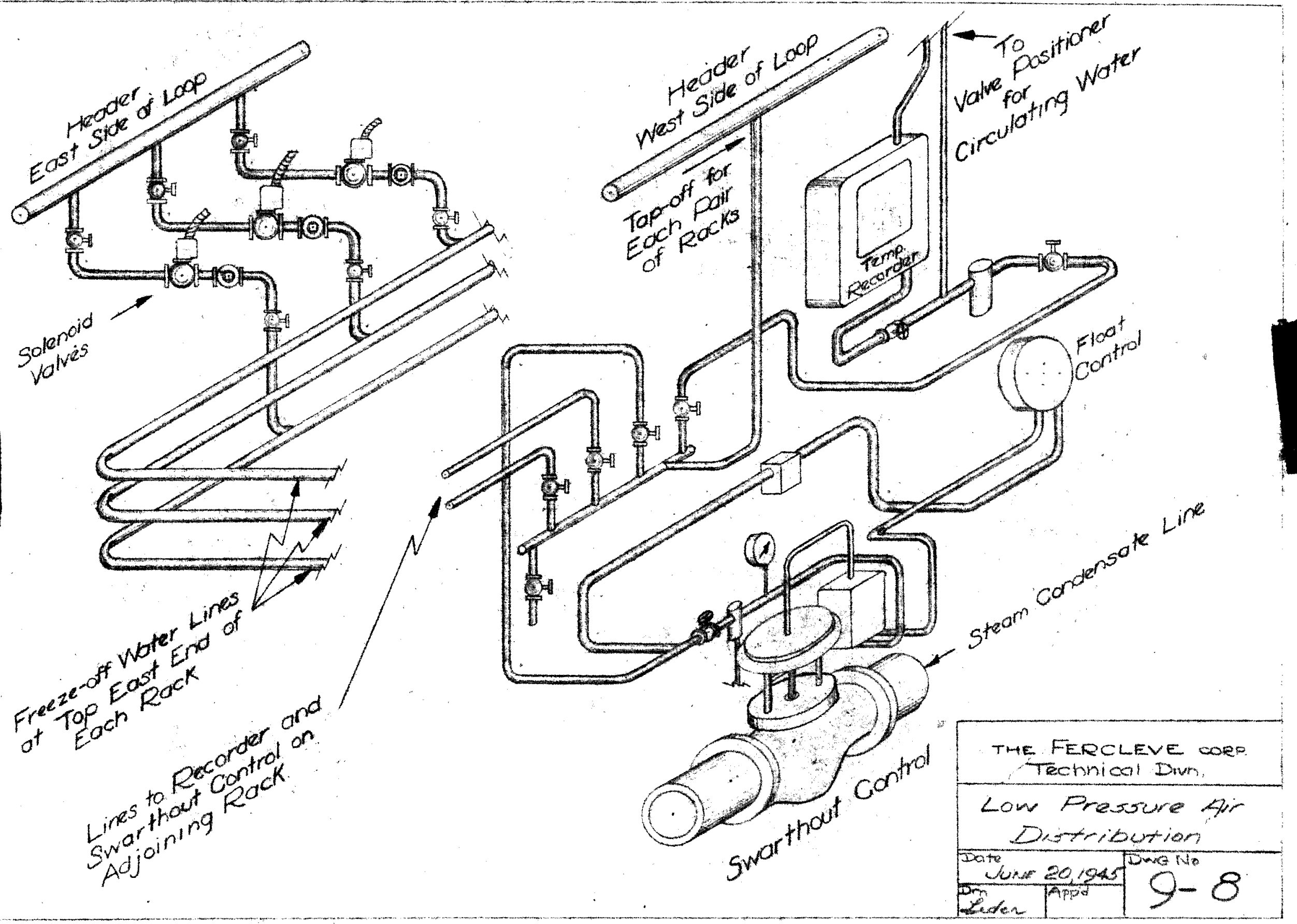


$$
\text { A. } 1.5
$$

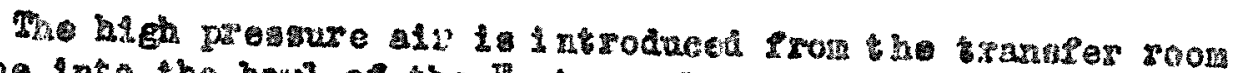

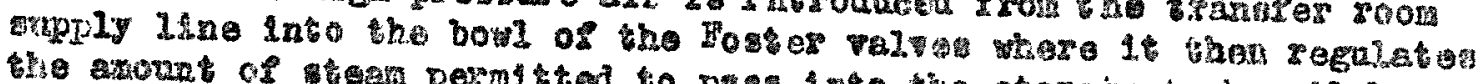

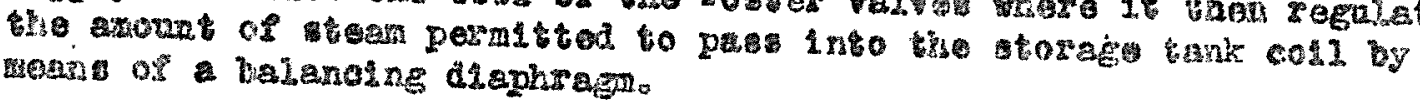

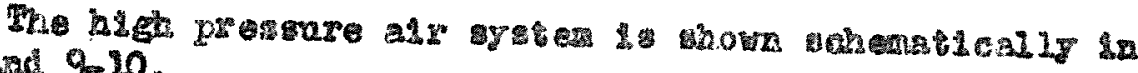
Ing. 9.9 and $9-20$.

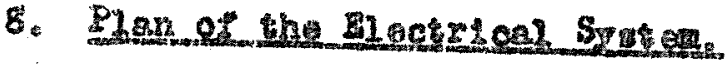

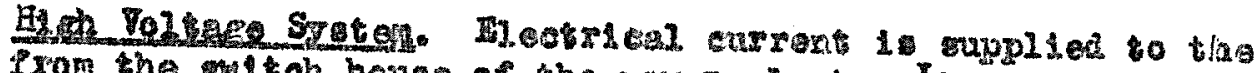
8.50 area from the mitch house of the power plant. It is complien

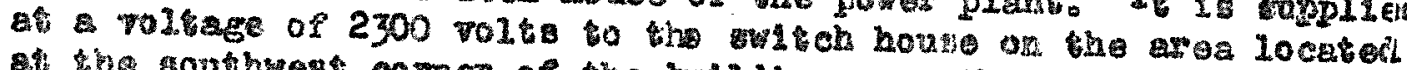

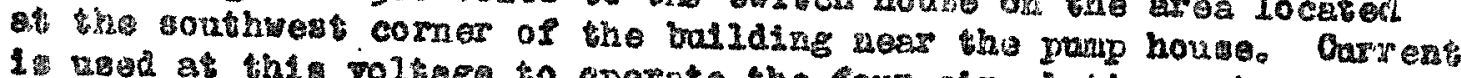

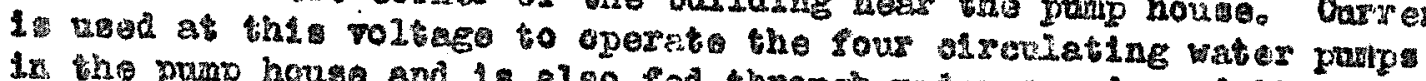

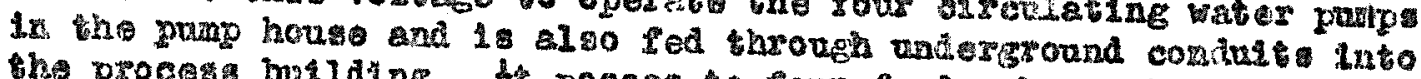

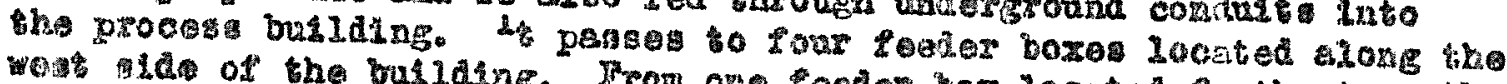

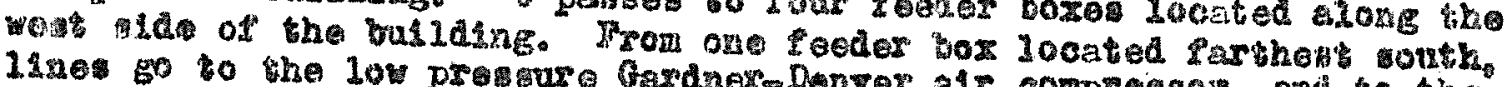
11nes to the low preswure Gardaex Dorver als compressos, and to tho

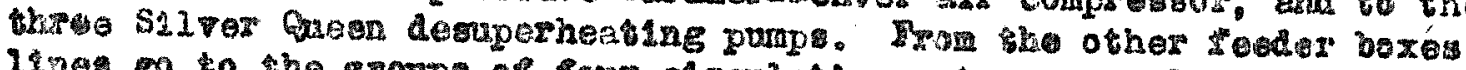

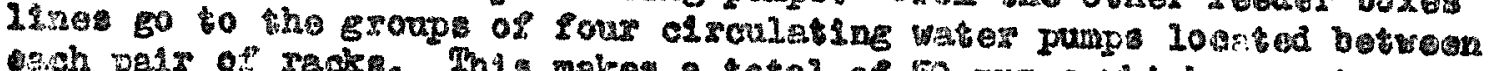

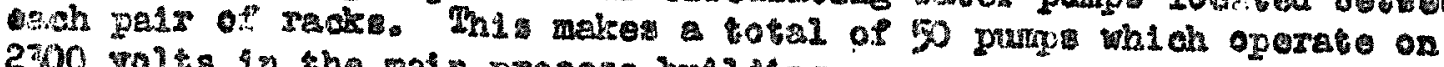
2500 volss in the matn procoss bud Ldisg.

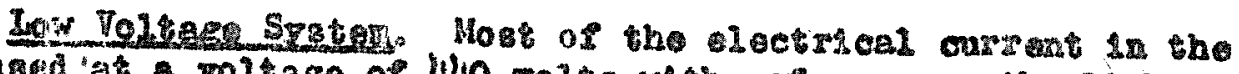

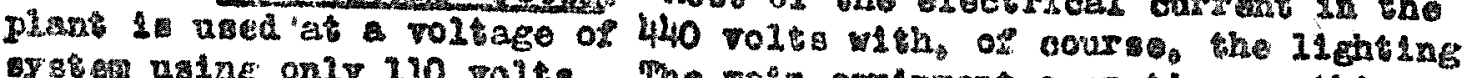

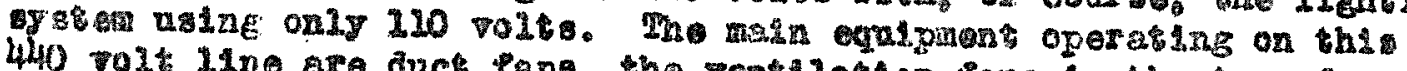

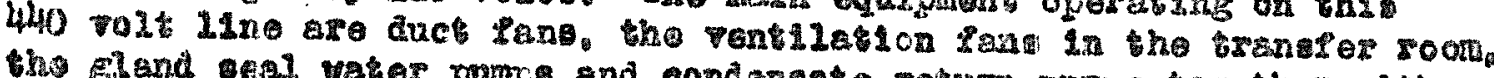
tho gitand wat water prom and condsnat rokurn prom together wh

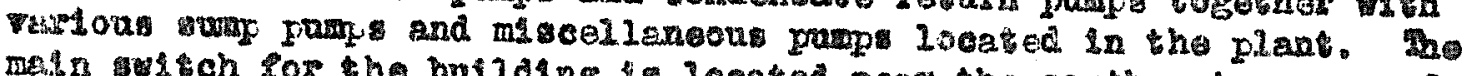

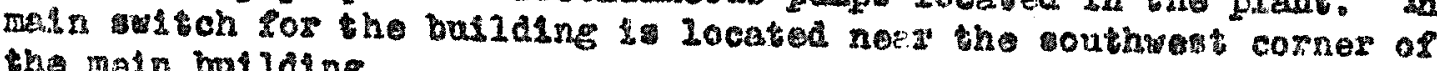
tho mala baliesng.

Since the 440 rolt gyoten is a throe phase aystan, tho

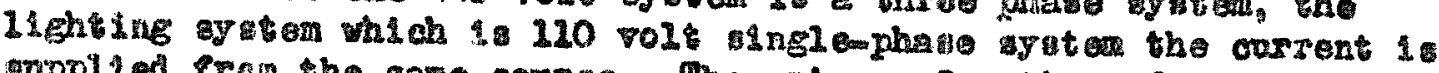
cappliad eroin the ane cource. The primary tunotton of the low roltage

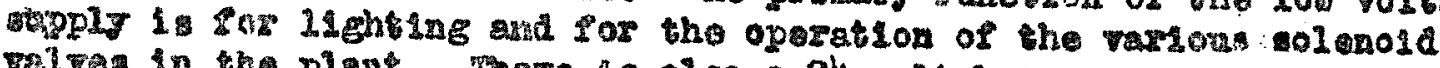

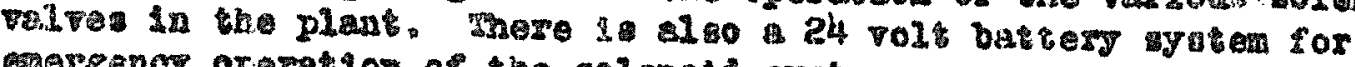
esergency oreration of the solenota gyatem.

\section{2hohntan os Operation.}

A atrober of operationsl techuques are omployea in the plant

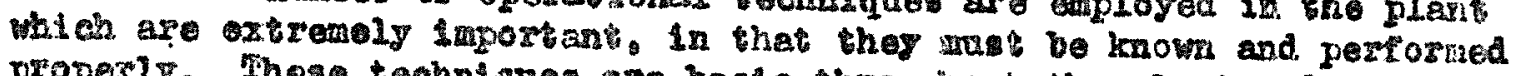
proper28: Those technigues are basio throughon's the plant ond aro ancans

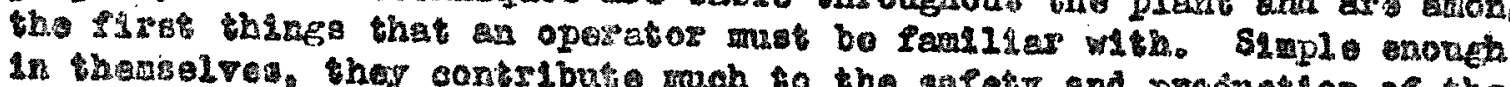

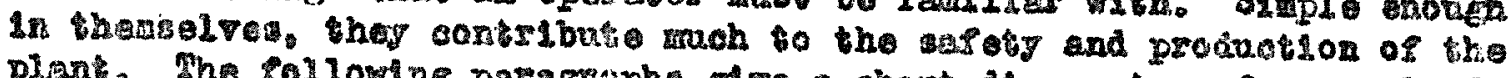

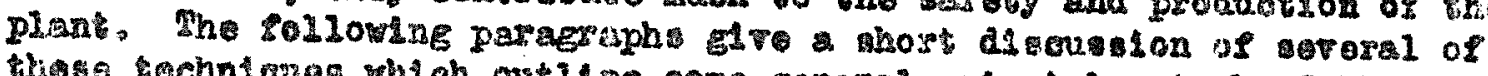
thss cochntque which outilne some generel prinelplas to be pollowed. The only adequate way for thom to be loarned, howerer. 10 actunlis to

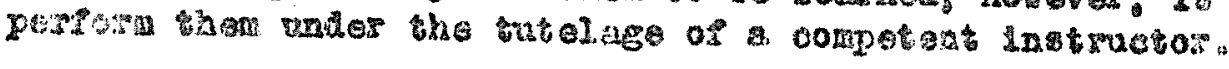




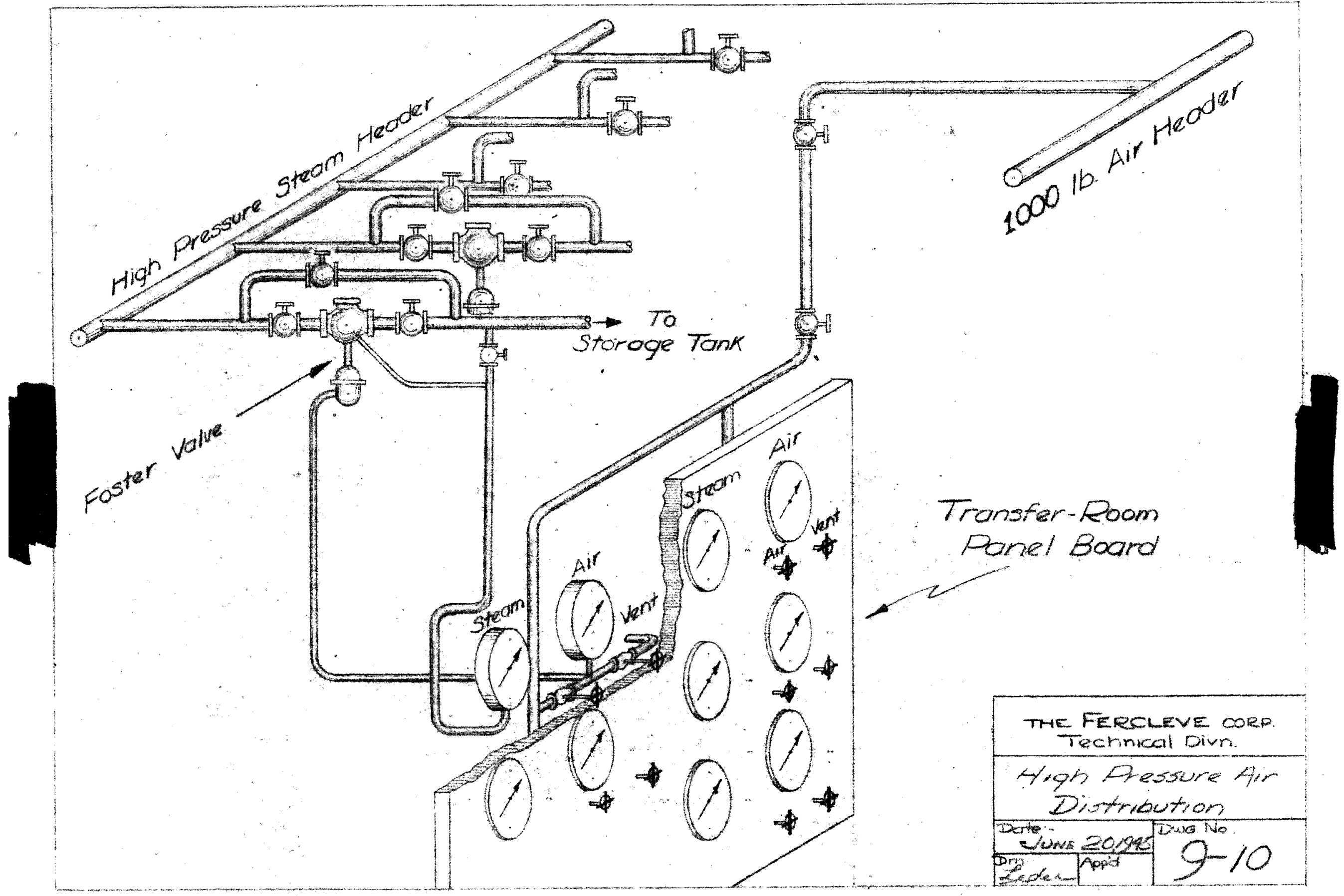




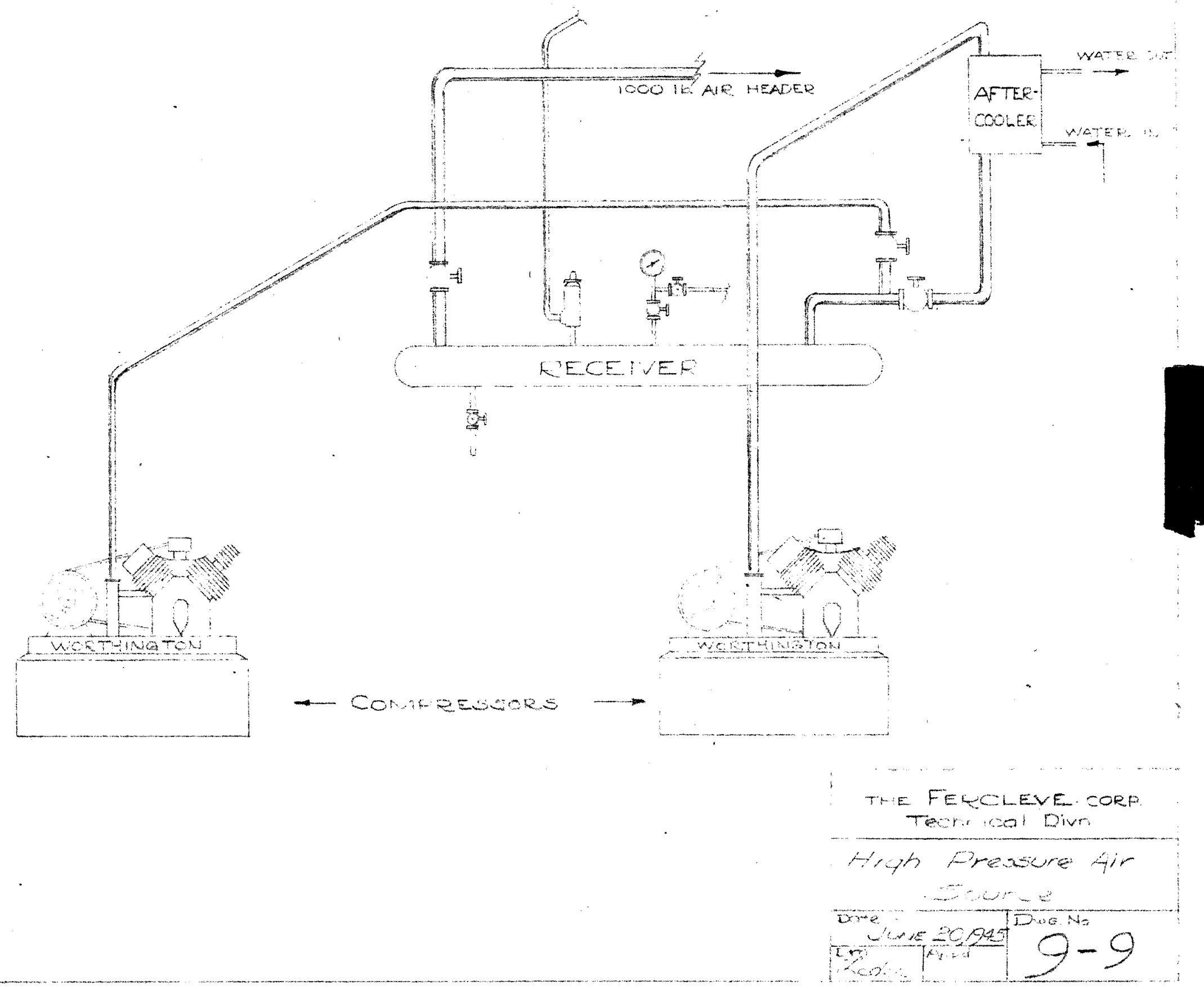




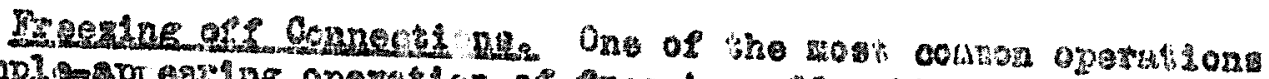
15 the 1aph

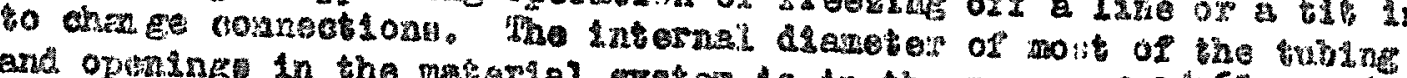

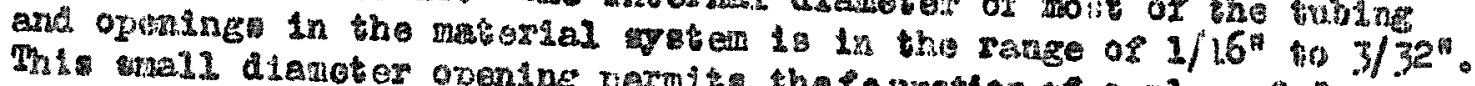

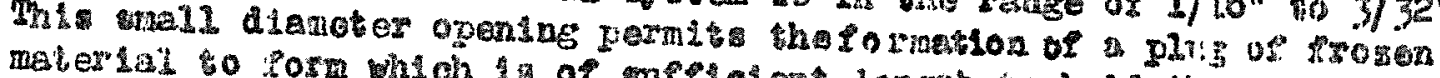
proverue of 1500 pound 8 . thet the total foreo operatio to

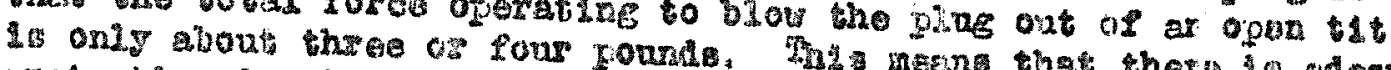

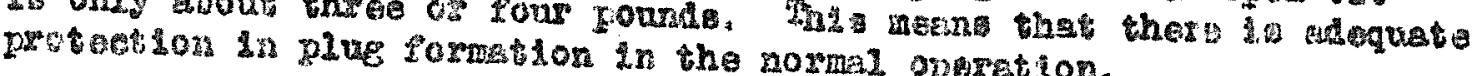

Is is owly st the plag 2 not propary formed or is the plag

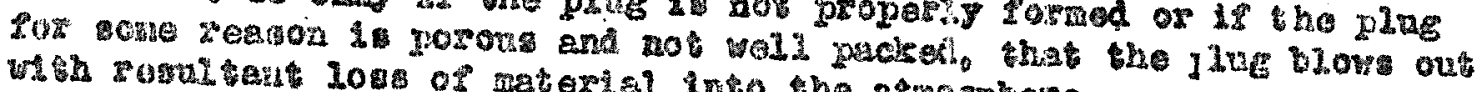

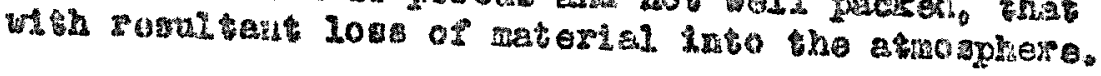

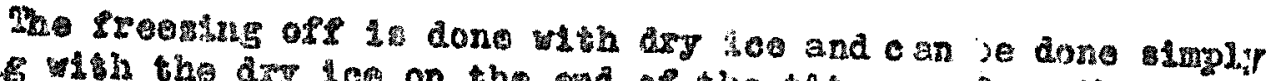

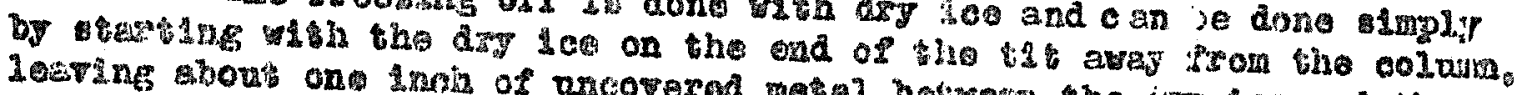

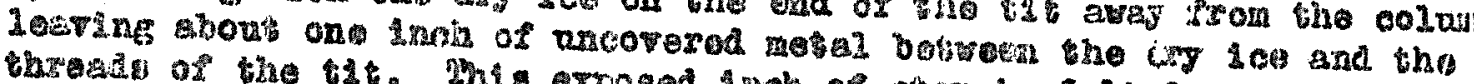

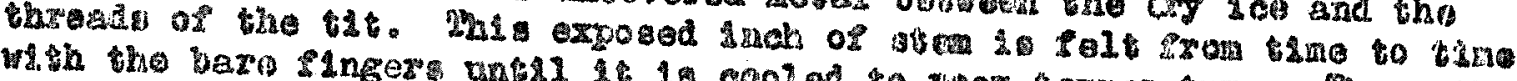

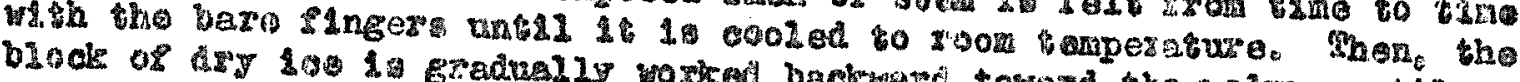

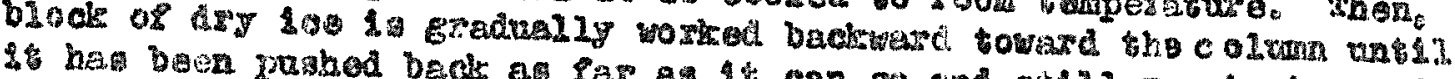

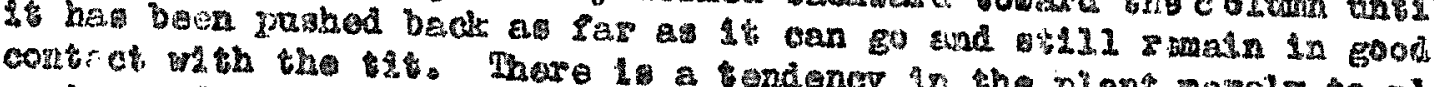

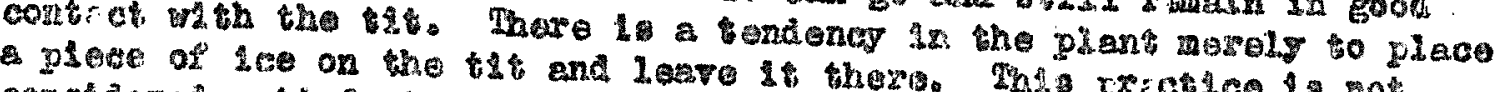

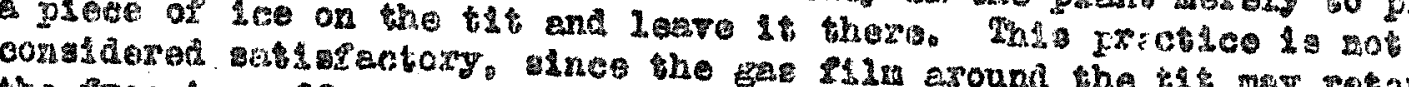

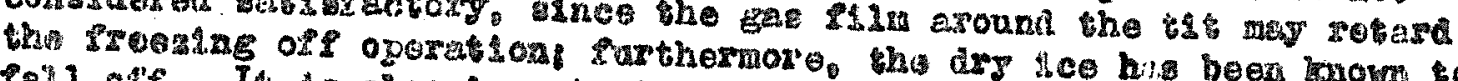

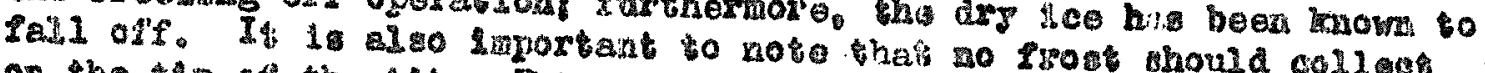

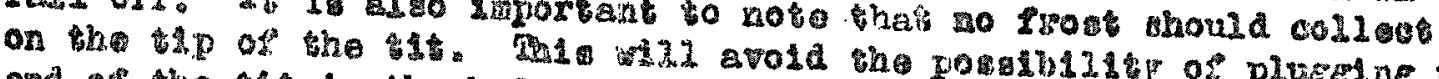
end of the 81 in the hritroly

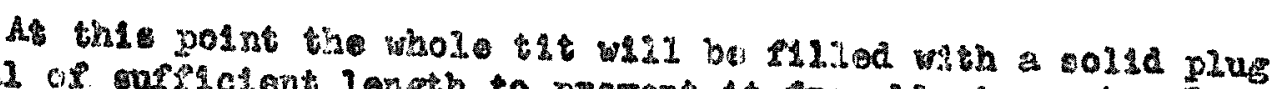

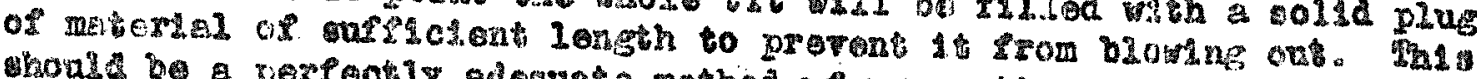

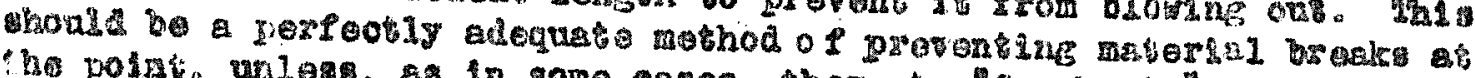

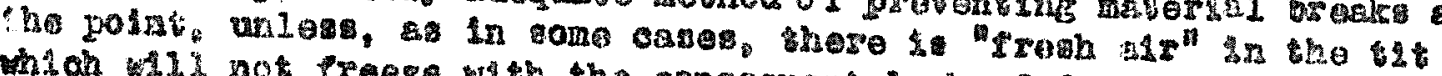

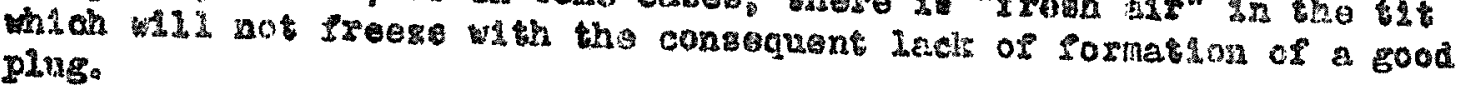

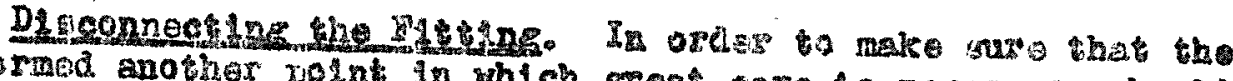

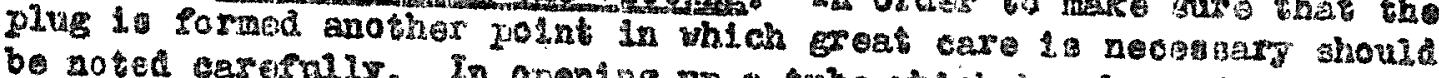
be noted terefruly. In oponing np a tubo whon hes boen froten oft. carth cularig ate at the top of the colum which as nor probablisty of

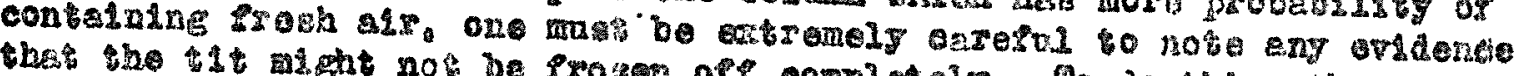

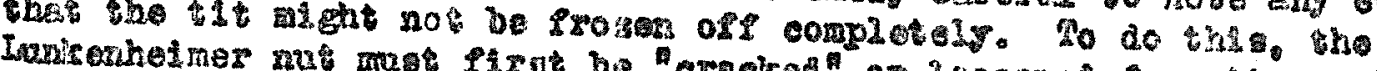

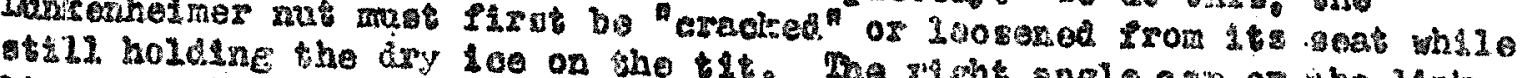

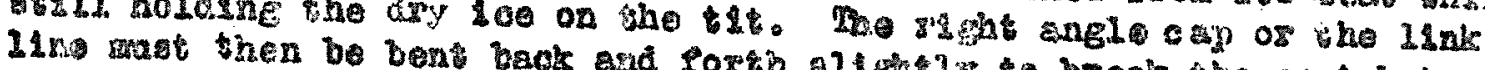

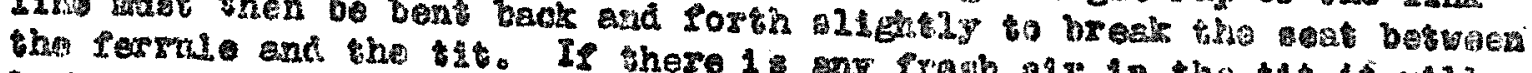

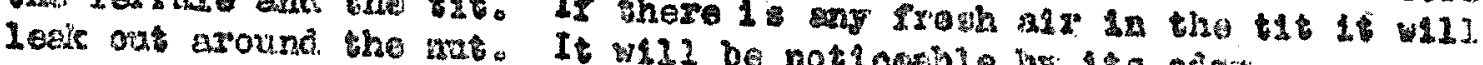




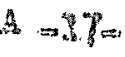

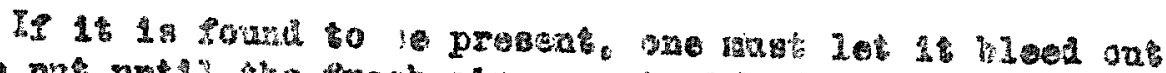

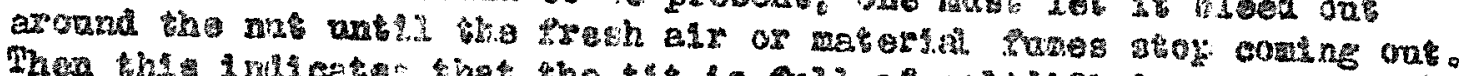

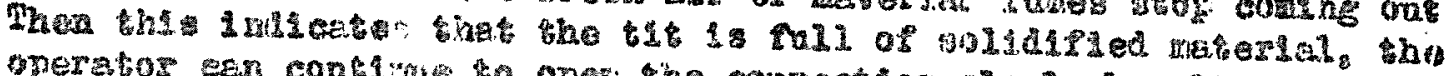

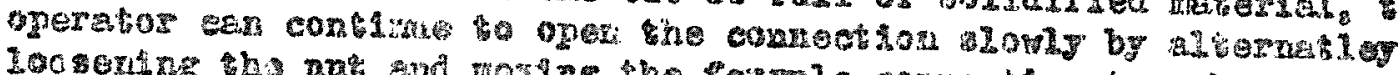

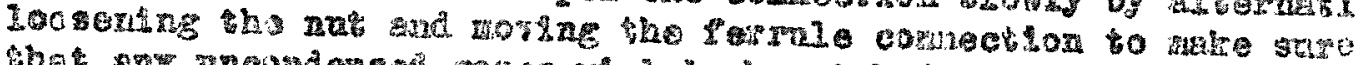

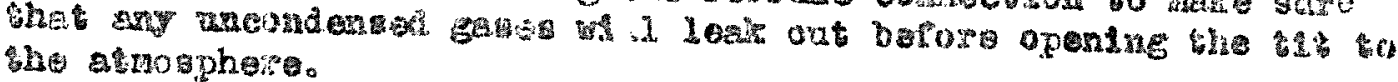

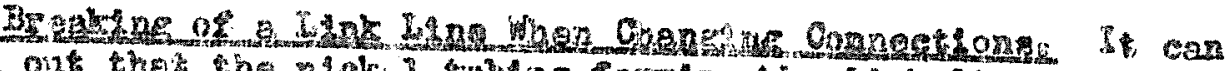

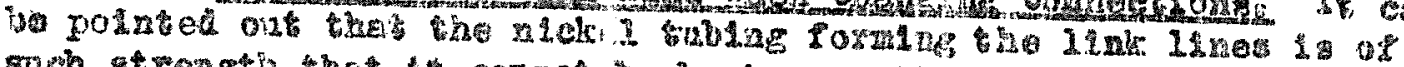

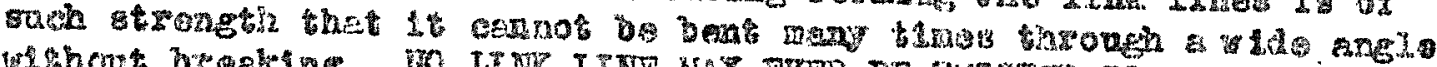

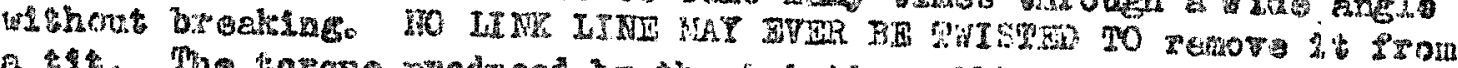

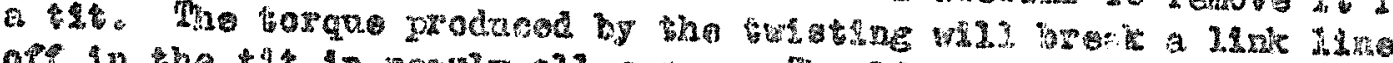

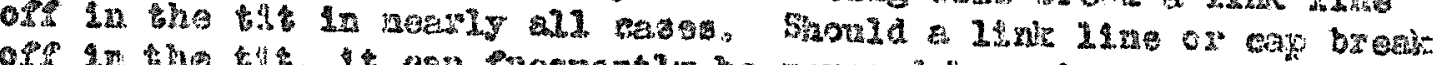

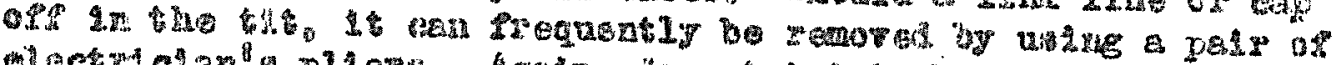

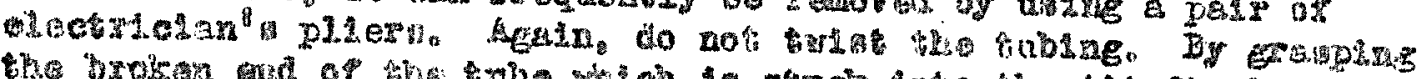

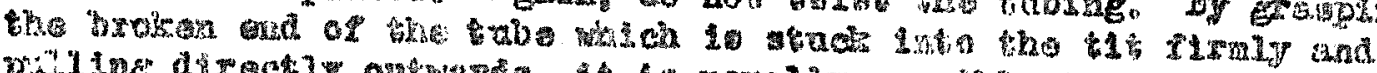

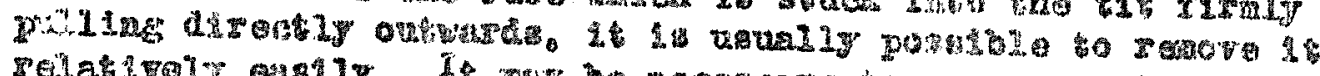

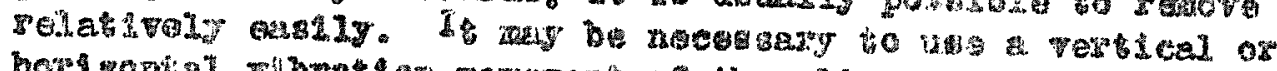

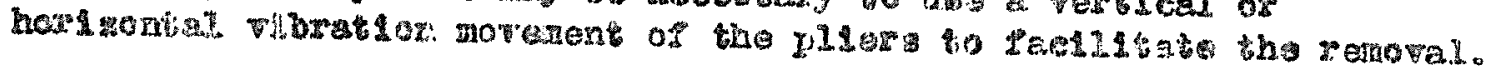

It is sapor

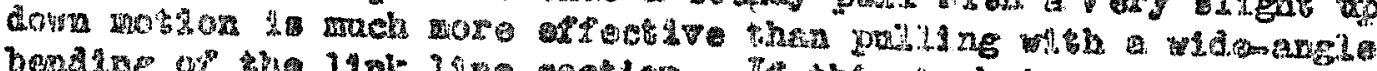

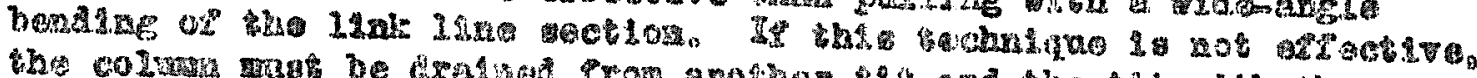

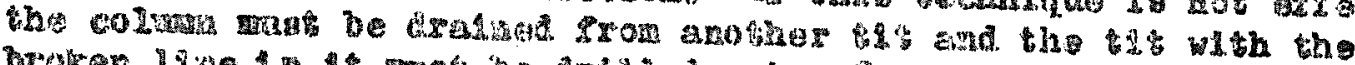

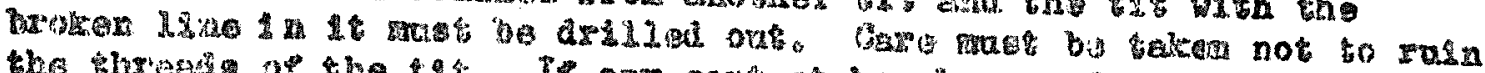

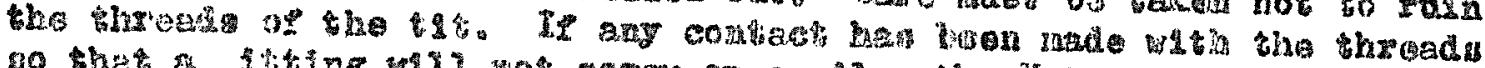

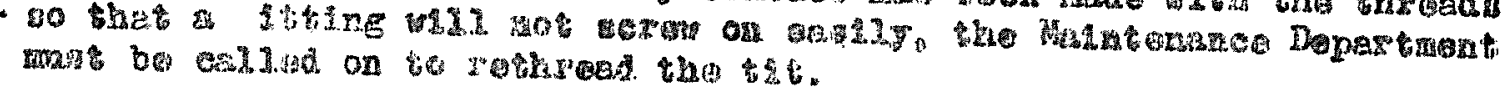

Ghing

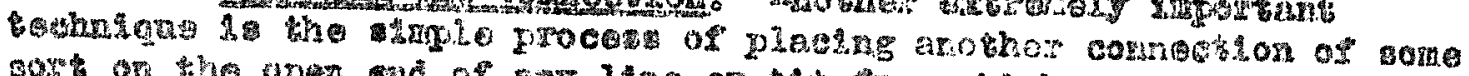

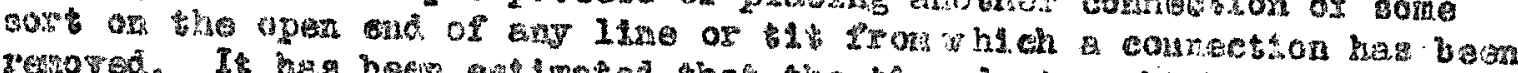

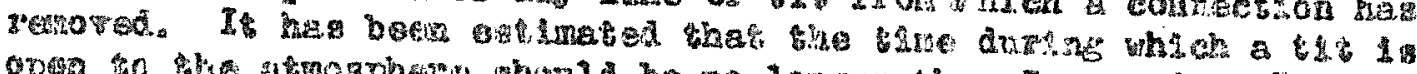

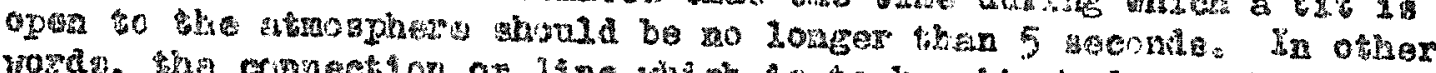

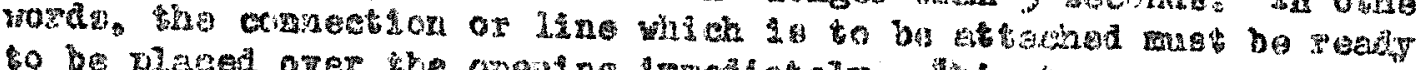

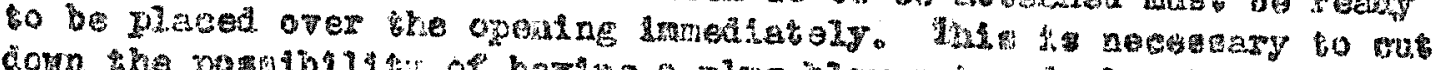

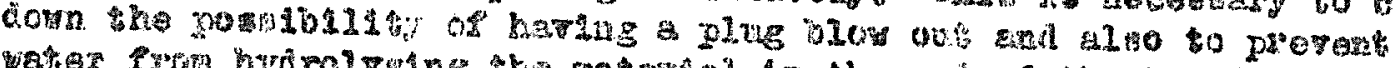

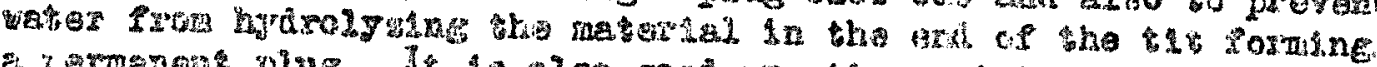

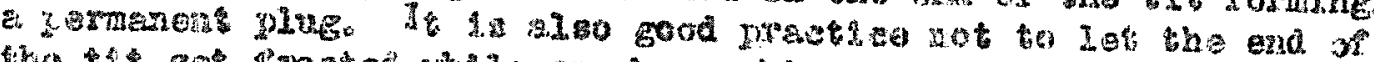

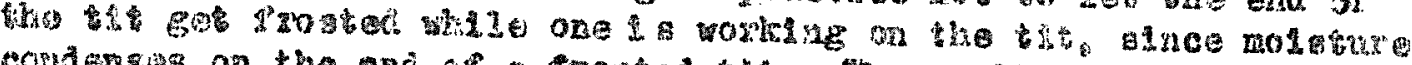

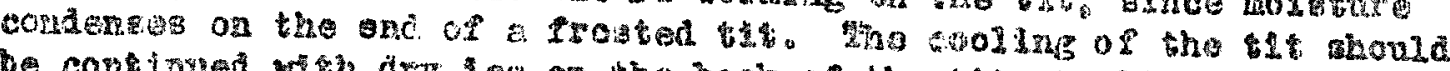

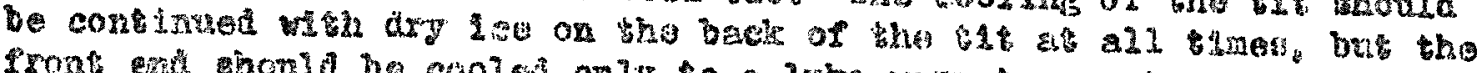

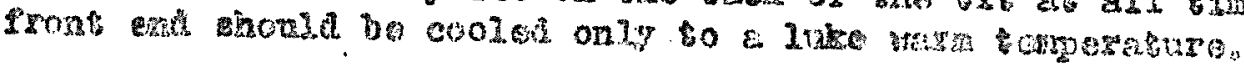

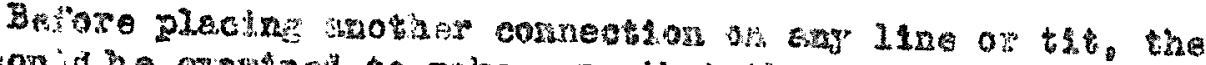

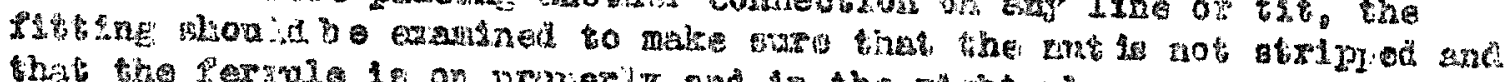

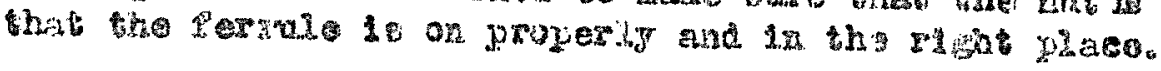




$$
\text { A }-18
$$

Wormlng up a Itine. The remaining step of waklug a change is a connection 18 the process of varming up the tit after the connection 16 changed. Uevalis it is considerad botser to allow a connoction to that out from the heat of the duct or vorrounding atmosphere in order to arold any sudden expansion. Howerer. mometimes it is necessary to speed up the procose which can be accomplishod by the judiclous une of a gas burner. The flaning process again is a stop that wast be carried out very carefally. Ince the properties of the material are cuch that a tremendous expanelon takes place in the nelting of the soldd.

The Important factor, then, 1 to to have wufles ent rolune for the 11quid material to expend into as $1 t$ changes is a utate. In other words. ALWATS FLAND ANI. IINE FROM A DIREOTION WHARE THE HATBIISI IS IIQUID OR FHOM AN OFDN BND. The operesor mast be rery carefol to noto that at no time shonld the matertal be heated above it aelting point whthout some pace to expand into ince it has been ostimated that, if the conter of a closed tube full of colld materlal vero heated to $100^{\circ} \mathrm{C}$. ithout this expention regtion, pressures ronld be developed in excesn of 10,000 ponde. This is in excess of the cafoty if etor in the plant.

Nolatine Featl. Another of the common procedure in the plant is the procese of determining whether or not a ryton or part of a yretea 1. dry. One of the older method was the drylne of a sy tea by pumplag 1t down to a high vecuun whlle horting the syoten a hot as possiblo. After drying an completely as posible, a glass trap wes inaerted in the lino and the trap immersed in ilquid nitrogen. This was done usasily hy booking rubber connections to the trap and alloking the racuam to be pulled through the trap for several alnutes. After equilibrian in the tablng with roppect to the vater content wes reachei. Ilquid nitrogen In th Dowar nash was ued to freeso ont on the wall of the trap the water emerging from the sjoten. The trap which had jreviously ben tared conld the be rewolghed and the nol sture deterined. It was

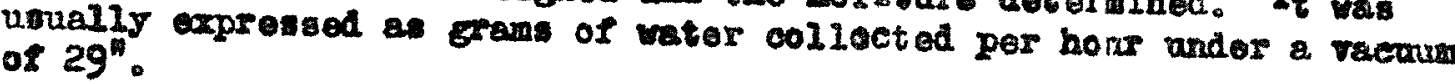

It ras found that the eracuation of the systes was an: adequate in arying out the metel properig and that ise molsture tent vas often spolled by humid air leaking into the eracuiter aystem. the pian was then adoptad of blowlng dxy nitrogen ga ilwough the syaten to broep out the molsture. Mhis nolsture was thon collectad in the came manner as given above by froving the nolsture oat 2 ia a tans trap

Qnelitetire Tentig. The rethod ased at preaent for criak qualitatire teste on Indirldual columns is a nodiflectlor of the llowing nitrogen test. In this test the altrogen 1 s lased throkgh the bottom of an individual colvm or peir of columns and a one minate test 18 ran with the liquid nitrogen and trap. f Visual determination of $t$ he water collected serves to ellminate any obrlonsly leaklng colemne. Mise 18 not satiafactory for mall leaks of molsture into a sotem whise existence can only be derinitely proved by a careful quantitativo test lasting a half to one hour. 


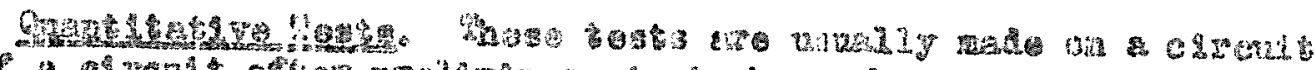

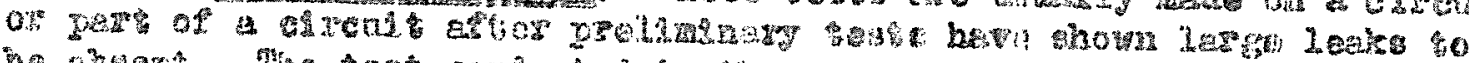

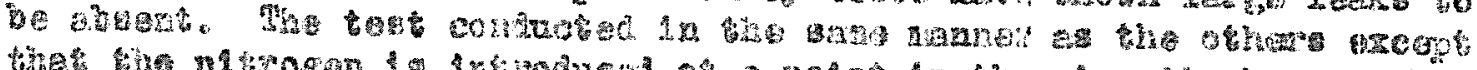

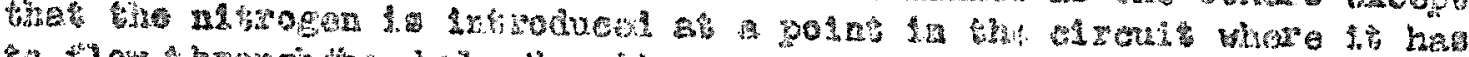

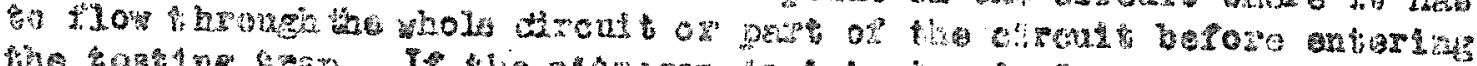

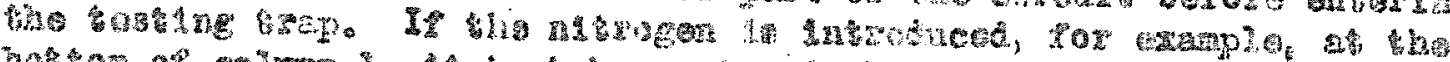

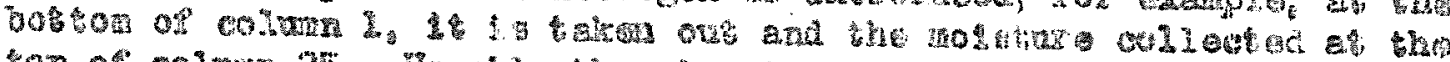
top of colum 25. Usual.

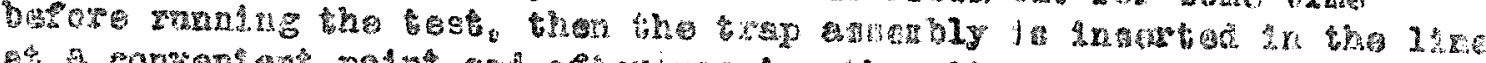

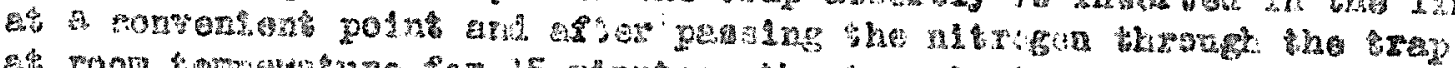

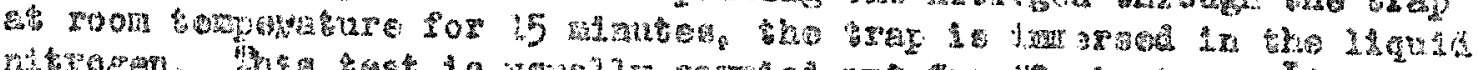

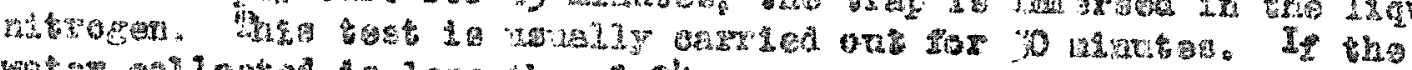

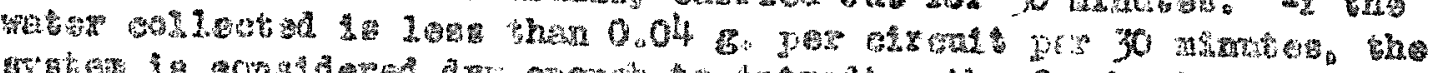

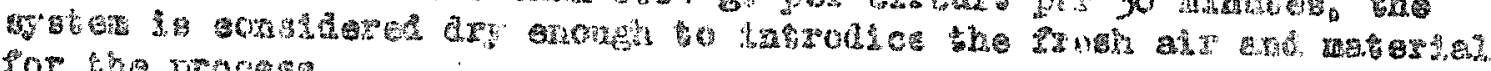
Por txa Hoceno 


\section{Gopera I Desoriptzon of the Treafar Roou}

The transfer room is located of the mezanine level which is along the west side of the plant. The rooms aro eleven in nuraber, whioh means thet each room serves two racks, excopt transfer roon eleven which is only used for Reck 21. AIl of the double rooms are imilar in construotion and layout, whoreas traysier roor eleven has the same equipmont and design but only half as moh as the other rooms. The double zooma differ in that sowe of the rooms are reversed in their design from the others. In other wordis in some of the rooms the valve syatem for the transfor fanks is on the south 8 ide of the $x$ oom and in others it is on the north sides The relative layout of the roons is the ame expept for this reversal. Seo Drgo Ho, $9 \times 110$

Howevar, before deasibing the room, the soale tank itself Flll be desorlbed in ordar to olarify the fumction of the various parts of squipment in the room.

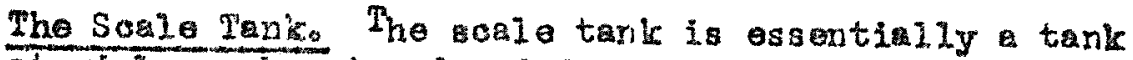
in wich waterial car be stored and frme whioh it osn be placod in the columens of the raok and from which the rack can replenish its supply as the product is taken off. The tapk fiself acasists of three parts: The niokel pressure ressel containitg matorial, a stoel jacket surfoundis it and a high pressure steam ooll in the conter of ito The purjose of this arrengement is to allow the matoriel to be heated ith low pressure steam in order to melt it, to be heated to high temperature by 1000 poind stean thus developing the operating pressures: and also to allow the tank to bo ooolod off by intzoduotin of coid water into the outar jeoket in order to solldify the neterigl. The other equipment in the transfer room is largoly auxiliary to the acale tank

(Desoription of soale and mounting also desoription of barzioade will follow in reviaed copy) 


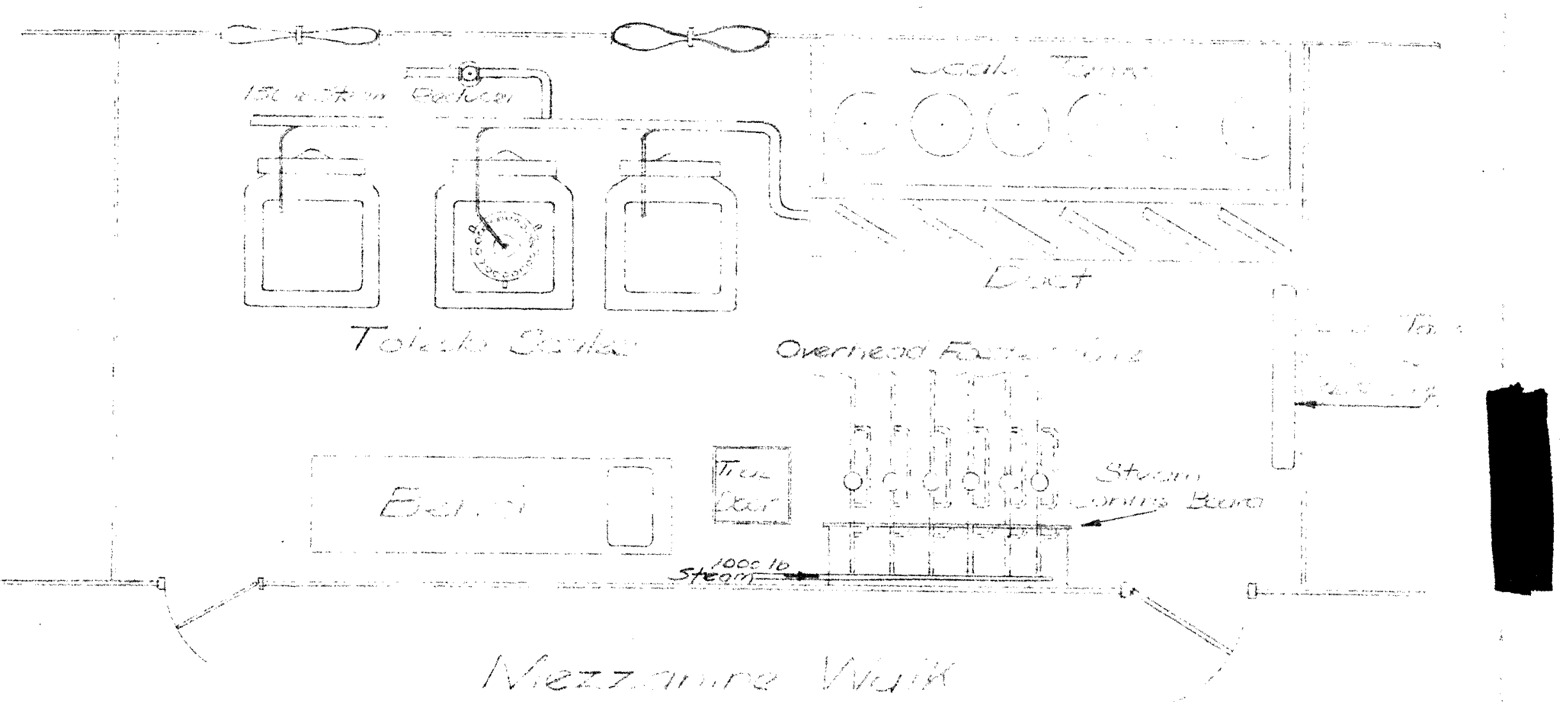

WE FEOCLEVE COE - और

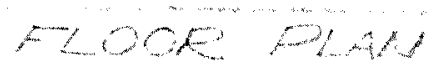

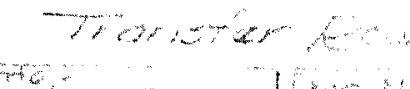

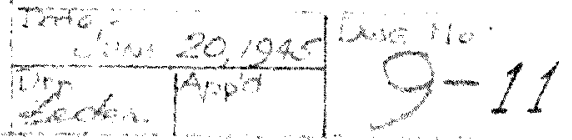


125 Pound Steam. Probably the nost extengivo aystem in the room is the 125 pound taan systom sinoe it is used to facilitate the transfer of material and also to heat up a numer of linas. There are three steam lines eptering the room. One of these is looated behind the ma in door of the room and enters noar the oeiling. This Iine enters and splits into two seotions. One of the lines passes through a reduoing valve which reduces it to a 5 pound pressure, fittod with a by-pass and gauge on the domstream side of the velve, and frow there passes through one of the $1 x$ valves into the jaclest of the soale tank. It is used for heating the terial up slowlyo The other branoh passes through redueing valve and by-pass assembly into the line wich ie used for heating the duct. The reduoing ralve is not adjusted to reduoe the pressure sinoe it is neoessary to obtain as high a pressure of steam as possiblo to heat the duct properlyo The team from this line, after passing through the duct, goes to condensate line whioh oontains another trap-by-pass assembly and ampties into the oondensate return lino.

Another line enters from the ond of the transfer room farther from the main door and goen to pressure roducing valve located near the vault. This goes through the reduoing valve and gauge ine to the transfor pot were it is used to heat up the shipping tanks when transferring material into the soalo tank.

The condensate line from the transfer pot enters return header and passes through a trap-bypass asembly into the low prossure condensate return lino.

5 Pound Steam. Another 225 pound steam line comes down from the top of the plant and passes through a preseure reduoing valve looated just above the roof of the tranafer room where it in redueed to 5 pounds. It entera the transfer room at a presaure of 5 pound at the and farthar from the in door. It aparates into two brenohes with one branoh going to the transfer conduit conneoting the tranafer pots and the terminal bos in the duot. It ia used for heating this line and goes through the 1 ine into the unul trapbypars unit and thence to the low preasure oondensate return line. The other brenot passes along olose to the ceiling of the room to the oomer of the room by the coal e tonk yult where it goes into the oonduit and is used for heating the oonduit. The condensate return for this branch is on the rack st the other end of the oonduit.

1000 Pound steam. This tean 1 ine inters from the 1000 pound header outaide the tron a fer room and pasees to the Foster pressure reduolng velves. There is a 1000 pound stean gauge on the ocntrol board. The Foster valre hes an inlet for eteam on one side of alaphragm and an inlet fop ais on the other lde. 


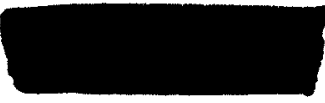

This steam preseure is regulated by oontrolling the air, supply by a valve on the board. This valve regulates the air supply which in tum regulates the amount of steam which is permitted to pass through the valve. All of the rooms huve the Foster valves equipped with upstream and downstream out-off valves and by-pagses and most of them now have 1 ines leading to gauges on the board which are looated in such a position as to show the pressure which is in the line even wen the valve is on the by-pass. The steam pressure is registered on the left of the two gaues attached to each Foster valve line. See Dwg. $9-10$.

The oontrolled steam pressure passes from the reducing valve into the top of the 80010 tanks where it pases through the coils running through the oenter of the materlal chamber. It leava at the bottom through the trap-bypass assembly and in to the 1000 pound condensate roturn.

Water Syetem. The water 1 ine enters the room in the oomer behind the matn dooro It then passes through a solenoid assembly which is connected to the general freeze-off system on the racks. These solenoid ralves are bypassed and are usually operated with the bypass open without relying on the solenoid system. This allows more flexibility of operation when working with different tanks. One branoh of the water lipe goes to the header along the top of the duots whioh furmiahes water to freere off the tits on the scale tanks. There is a valve on each tank which permits the water to flow through the oopper ooil whioh is in controt with each tit on the tank. They are all frozeo off together at the present timo but some experimental work is being, done to develop a mothod of freezing then separately particularly alnoe it is desirablo to know the pressure of the tank when the rest of the tits are frozen off.

The other branoh of the water line goes to the valves on the side of the roam near the soale tapks through which the water goes to the outer jaoket of the 0 lo tanks. The assembly is arranged so that water and ateam pass into a common pipe so that either water or stean may be paseod into any of the jeckets to either thaw or freese that partioular tank. The wer and steam pass into the condensate roturn $I$ ine through a rubber sonnootion at the bottom of the tank. Another water 1 ine goes to the sink in the oubinet in the room. It drains to the sewer.

A1. Systemo The 1000 pound air IIne enters near the 1000 pound ateam line and goes to the header furbishing alr to the Fouter valves: There is also a glage on this line loosted on the control board. The if goes to one ide of the diaphragm wioh controls the stoum pressure. Ihis prosaure is held until the air vent valve is opened on the sontrol board whloh releases the air pressure on the valve and oorrespondingly lowers the steam pressure on the soale tank。 
The right gauge of tho puir for eaoh storage terk is the alf pressure that is on the diaphragm. The gauges shoring stean pressure and air pressure should be vory close tegether in readings or the stress on the diaphragn ma bo sirat onough to break the diaphragm, $s \in 0$ Dmg. 9xio.

The Jow pressure air line runs along the weat wall o. tho room and has an outlet in the neightorhood of the transfer pot prossure reducing velve. This is us ad fror blowice out oquipment and for olesning operations involving the forcing of ifquids through
oquipment under pressure.

\section{Hethodu of Condutioning Fquipwont.}

\section{Conditioning Seale Tanks}

The fundamental objective of 38 le tank conditiongh is to obtain a cl asn vessel free from eirt, nickal coide and moterial decomposition products. inless these forejga nutarials are oompletely removed, the otorage chamber atil art as a source of plueging substanos thot will iatertere with proper operation of the rack

(1) Storege ohambers should first bo complotely driad. Rough arying at be acumolished by opening all tits and introducing theolagh the top titi stream of air wille maintainiag 5 pound atuen on the outer jacket and 150 pound steeris om the imner coil the tits should also be chacked to make suro that all of them will pass alr through them and are not wolded shut, liemoval of the bulk of the noisture can he oheched by holding a cold mirror next to cane of the tits. All tits should than be capped except one serving as a laed to the recuum pume.

(2) The chember should be svaougted through a rubber hose attached to the tit until the gruge has

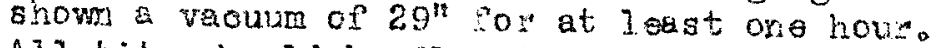
All tits should be flaned prom time to time to guareateo that water has rot accumulated in them. It is essential that roisture be thoroughly removed because ifter in the proosiuro when the material is introduced obnoxious plugs will form in the tits if the drying teonnique has not beon surficiently ragorous. 
(3) Cunnectione to the chember should bo changod to pormit the introduation of fresh air. A line should be $x$ un between the fresh air valve to the ohamber and oomections to the veoulu pung altered so that when fresh is is introduced the gas oun only come in contact with an al1-metal system. The chamber should be then re-evacuated to 29", the valve to the pump olosed, and fresh aif introduoed into the chamber to a pressure of $10 \mathrm{pes} .1$. Tho chamber should remain filled with tha gas for an hour at whioh time the pressure can be relieved to atmospherio oonditions. The comections to the fresh air val ve and to the vasuum systom should be removed and the tits omployed for this purpose should be capped.

(4) The next step is a step that has been followed throughout the conditioning of nearly all of the soale tanka. In oonditioning the last several tanke that ware conditioned the operatora did, howovar, eliminate this stop with no apparontiy bed results. This item is to introduoe into the tark about 8 pounde of material. The material itself is ono of the best oonditioning 6 ubstances there is so the principlo to let the material condition the metal in this step. However, there was some thought, that the fresh uir would be satisfectory so it is possible that this step aan be oliminated in the future.

During the intraduation of this merial, the central stoam coil noed not be heated and the temperature of the outer jaoket an be ma inteined at a satisfaotory value by heating. with 5 pound ateam. The tit through whioh material has boon introduced should be frozen off and orppod and the central heating coll aotivated with 1000 pound steap for at least 6 hours.

(5) The material should then bo ramoved. It is advisable to uso sope sort of a trap far oatohing the lorger part of the material but, while several traps have been developed, none of them 1a partioularly satis faotory for saving an approciably large quantity of the naterial. It has bew necossary to blow the terial out into tho duot cond lose the jor part of it. This is not eoonomioally or healthfully advisablo but if a link line is run some distance up into the duct and the material lot out through that 1ive, it is possiblo to remove most of the material vithout a great quantity soming out into the room. 
Whon the pressure in the tank has droppod to atmospherio pressure, the remainder of the vepor should be thoroughy blow out by introduoing disy nitropen throurgh one tit while a second is unospped. Tho altsogan should be blowe through the chabber wotil the outgoing gas no longer shows any signs of aterial. All tits should then be opened and flamed in order to ret a froo pasage of nitrogen through themo The operator muet romember all seven of the tits, including the one in the top and also the one in the botton, both behind the armor plate in the valt. If these tits aro not froed of material considerable difriculty will be experienoed later when water is introduosd, because the will form plugg with the material.

(6) The storare chambers should bo washed with water to remove decomposition products. The volums of the vessels should be determined by woighing them full of water. The water thould be $x$ un out of. all the tits until it is colorless and froe or all decomposition products. The chamber should then be drained through the bottom tit reoording the weight of water semoved. The weight of the water renoved should be the same as the woight full. If these figures do not choak satisfactorily the tank should be filled aga in and the volume and woight detarmined.

(7) The tank ahould now bo thoroughly dried. First, rourh dry the tank by blowing dry air through it while the chamber is being heated as wes dono in the first stop of the conditioning. Rough drying should be followod by a oareful pumplag procedure in whioh the chamber is ovtocuated to vacuum of at least $29^{n}$. Air is introduoed into the ohamber periodically to aid in flushing out any residual water vapor. At the end of 6 hours dr'y nitrogen should be adnitted into the tank. After several minutes of flowing nitrogen through the tank by passing the aitrogen in through the top tit and out the bottom, attach - glass trap to the bottom tit and imare the trap in liquid nitrogen in ordon to test for the presence of molsture. Pass the nitrogen through for 5 minutes and woigh to the nearast oontigram. If the moisture test shows the presenoe of 1 ese then 0.04 gram of tater, tho tank my bo considered dry enough to fill. Also make oerta in that all tho tits aro dry. 
(8) The ohamer should be rewevecueted and sresh air inmediatoly introduoad to a positive proseur of 10 pounds per square inch. The 5 pound stein chould be turized off the outer jeoket and 1000 pound stam fin through the cential heating coil. Freah air should rema in in the oharaber under pozitive pressure until operators are propered to introduce progess fluid.

(9) Fresh a cremections should be removed aud a sustable jumper to permit the introduction of matorial should bo comnotid.

(10) With 1000 pound stean still on the inner coil and no Now of fluid, stoum on the outer jaoket, the roading of the scale of the storage chamber should bo tarad to 29 ro.

(11) The high preasure stoam shovid be cut off and the chamber held at a temperatuzs of $800 \mathrm{C}$. by intzoducing - mixturo of 5 pound steam and cold water into the outer jacket. Whon the outer jaoket has beon fillad this hot tor the woight on the soales

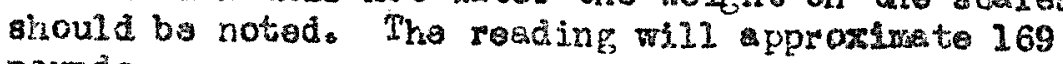
pounds.

At this point the tenk is roady for the introduction of rates ial.

\section{22ansfergy ing Materia 1}

\section{Q. F1I11ng Soalo Tanks}

The rixst stop is to make sure that the Soalo Tank is maty, the tits flamed out and sxoe and that the ocalo is properly tared. Also the operator must make sure thet the full transfor pot is roady on tho platform soale in the jooket.

The steps to be sollowed are outlined as follows:

(1) Connset inlat and outlet steam lines to the trunsfier pot jeckot.

(2) Ranove valve ouy from the transfor pot and put on the adepter. Waico suse that the lad gasket in the val ve asp does not stiok to valve plugging the line. the adaptar and gasket should bo well flamed bofore purting on the transfor pot valve.

(3) Connect thensfer jumper to transfor pot valvo and trensfer ocudust tito 


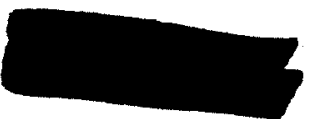

(4) Conneot link line in duot to acele tank tit and to transfor conduit tito Be sure that the freege of: wates is funing on the ssaid tank tits.

(5) Tuxy stean on the truaser pot through the low par as Eu P.R.V. stert with 5 pound atean to whe the pot and to ohock the traps. Increase alowly a half hour latar to il bout 30 pounds prossure.

(6) Pus 10 p pessure stan or the soalo tank jacket to bxing the tomparature to $100^{\circ} \mathrm{C}$. Cheok the thap to 360 if they ara operating properly。

(7) opan vaju on pot and gans the whole line after

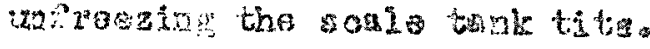

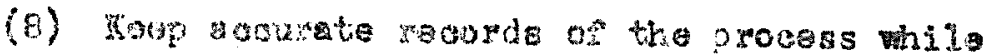

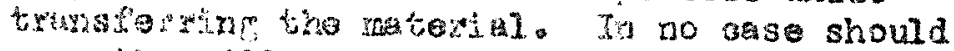
rao, thas 200 pouds bo allowad in tho soale tank.

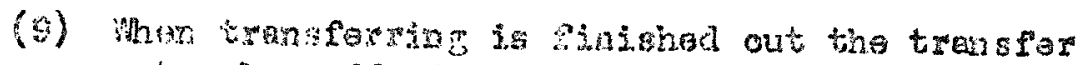

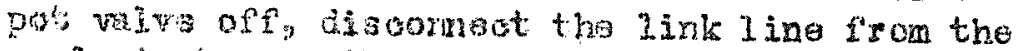

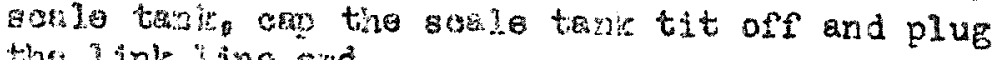
the link ino ond

(10) Adnit mater into tho somie tank jaokot after turnjug the stom of a wa the tarke is ready for operatistiso.

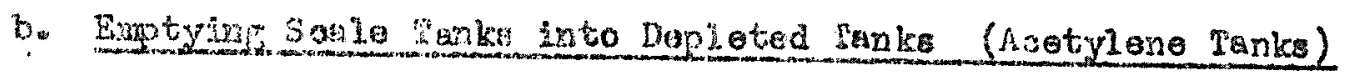

(1) Conzeot a now link line to tha soale tank tit and to the empty daplotion tume.

(2) Put high prossure stam on the soale tank. Warm the tank ip slowly at first tiren increase pressure

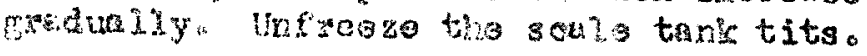

(3) Stat tho traesfer by hsating the line with bumer. Cipen the oylinder valve and continue hetting witil tiso matrial mores freoly into the oylinder. Incraane the stean prossure to 1000 polads nak the and of the tocusfer.

(4) When envty blow out ramidar of matorial into durts. This should rot bo nore than a pound or two lase cortain the fan is on. 


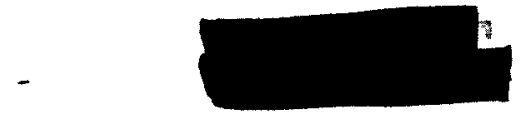

(5) Have sceles tared and the tark is ready for rew filling.

6. General Instructions for Routine Operation

a. Starting up Operations

With all the storege tanks full of material (420) younds and cirouits of the racks filled with material, the transfer room is now rady to oparato. Aftor determining the configuration of the ofrcults, the rack foreman will notify

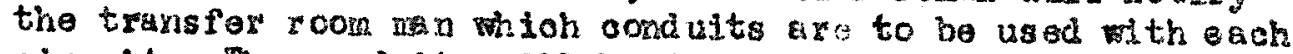
oirouito Tho condults will be dea 2 gateded by number The conduits from the raok onergo in the duct in the transfer room and are numbered from lert to sight.

Ints holds true whon thore ate 36 conduits por rack. In sowe transfor roons where temporasy or repla oenent oonduits have boen put in, the ocndustis are atampod or tagered with their respootive numbers. The transfor room man will tinen comlete the oirouite by oonnecting the oondults to storago tank by moans of link lines.

\section{b. Arrangement of Cirouites}

Two ci rouite are to bo oomected to one storage tank-this wons that the four oircuites af the rack will. bo servod by two storage tanks and the third tank will be hold in reservo. It is preforable that oirouit llo. 1 and IIo. 2 be on one tank and ciscuits No. $z$ and No. 4 be on the othar unless otherrise ordered by the rack foremen. A naterial prassure gaug must tinen be attached to the fifth tit of the stosage tanko It 1 a good polloy that the sonduits be attached so that the lowest nimbor conduit be conneted to the top tit of the atorage ohamber and the other three in the like remer, thus loaving the bottom tit for the posare gaugo.

\section{Establishing Comnuntoation with Eacis}

Tho olrouts having been completad, the transfer room ie ready to conanumicate with the raoko there are tro methods whioh may be usod in oatabliahing conmunloation:

(1) Mon Ciroulta aro Frozan off cn swoh at Botion of Rad

The froezowoff watar should be turned off of the tan is tits and low pressure stan tumed on at the mixing: valves to the jacket of the storage tanis for warming up and nolting the material. 
No hich pressiure steum should be used until the meterial has been oomplatsly meltod. Ihis oxn be oheoked by means of a thermometer insertad in the weil of the storage tank. It should read $80^{\circ} \mathrm{C}$. befor adding high pressure stear. If there is no hurry, it is advisable to use low pressure steam only until material terquarars of $100^{\circ} \mathrm{C}$. is reached.

When the materiel is ocmpletely molted, about 100 pound high pressure steam may be turned on the coil of the tank by propor manjpulation 0 : the valves controlling the Foster limgulating valve for this partioular tank. The jaoket otoan should now be turned off and only high pressuro steam used. Gradually build up the steen prossure until the desired material pressure (1500 pounds/ in' unies otherwise ordered) is reached as indicated by the material pressure gauge attuohod to the atorago tank. The trangfor roon is now ready for the rack to bo unerozan.

(2) When Circuite are not Frosum on Bottom of Raok and TIta of Scale Tank Rame in Frogen

Procoed as in (1) for Farming wo and turning on high pressure stean. At tris timo, sinos tho gauge is also frozen off, the neoussary tean pressure nooded to obtain the roquired matex ial pressure must be deterninec by uge of the material pressur e-gteam, pressuremeterial weight chert shown in Dwg. 9-3

Ndjust the steam prosiure eccordingry giving adequate marcin for safety. Of course, if the pressure is too low, when the raok is un ryozen the material will flow back into the 80010 tank. This on possibly make the raok pitoh. Endeavor to have the pressure as olose as possible to the pressure in the reok to avold a aurging of material.

When the material pressure is judged to be setwo isfactory, the froezomofe water my bo turnec orf the tanis tite.

¿. Genoral Noter and Procautions

(1) There shall always be two operators in each transfer room. 
(2) In dealsag with long, link lines in the duot, ramember that they $\pi \mathrm{y}^{\mathrm{y}}$ 000I off when the duct doors aro oponed, thus onusing the material to solidify. Such link lines conteiring golidifled material constituto oonelerable hazara, aa thay might bo ocidentally reated in the midd? of the longth of solid material by nearby stoman pipes or by a Bunsen burner Plame used in the duot to hast other link lines. This intermediate hoating, can ousily ceuse the link line to burets. A materal brsak in the trazsfer room is most sarious.

(3) Always use hoory lied tubing for link lines. Be oareful that they a re not heated above $1000 \mathrm{C}$. When the lines contain material uder high pressure, or heated at all, except carofuliny at the open onds when ontrining solid material.

(4) Nover put more than 5 pound stean or watex pressure on the storage tank jaciret as the rubber hose conneotion on the drain y break 10088.

(5) Whon ahanging 11nk line of materal gauge comnoction os atorage tank:

(a) Froeze off tita by means of the vater froeso off aystom.

(b) Foel of tits with the finger to rake oure that they are cold (alwaye oheak link line this way wher you think that it is frozen off.)

(a) Bring the high pressure stean on the storare tank to zero pressure.

(d) FLOOD THE SCALE TAITR JACEET WITF COLD FATER. (Most of the bad brealea in the trensfor room have been oaused by attempting to save time by olino inating this preokution. It is false oconony.)

(e) When the temperature of the storage tank has falien below $800 \mathrm{C}$. it is permissible to disoonneot Lunkenheinar fittings from atorage tank tits.

(f) As a final soourity measure, before starting up have enother oparator ohook. comaction before renewing operation. 
(6) In the rare case that the conduit innes logding to the raok have been frozer off by $\$ 100 d i n g$ the conduit jecket with wer, the following procedure should be used in thering out the conduit linss:

(a) Make sure that the storage tank or tanks to whioh the conduits are cormocted are heated; that the ctorage tank tits are thawed out, that cuot link linos are hot. In other words, there should io free movement of process eluid from the ocnduit Ines to the storege trinks. A.lso, make sure thet the raok ducts are not and that oirculation alons Iink ard convootor lines oan take plaoe.

(b) Tum down the oold water valve on the conduit irooze-off systom, slcwiy open the stos velve and mix the two so that the temperature of the ter rlowing; through the oxduit pipe rises gredusily to $70-750 \mathrm{C}$.

(o) Take half an how to bring the temperaturo up to $75^{\circ} \mathrm{C}$.

(d) Checil the temperature by asuring it where the water flows out of the end of the drain pipe below the rack duct.

(6) As the thawiog of the oondusts is an oxtremely delicate undertaking it should always be done under the direot supervision of the Tooinicai Superintemdent.

(7) Watorial should be addad to atoraijo tanise up to 420 pounds. Hake certain that at no tins does the weight in the tanks oxceed 140 pounds. operate a rak only from tarks containing a animum of 420 pounds.

(8) Do not operate more than 51 oolums on one storage tank at any one time.

(9) Haintain tho operatine pressure of the materiel in the raok at 1500 pounds. When milking raise the pressure to 1700 pounds but sinoe the aircuit drops to obout 1500 pounds while being milked, bo oertain to drop the tank pressure to is00 before ufreering again. This is to ko sure that no surge takes plaoe Irom the tank into the raok.

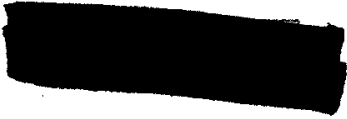


10) It is striotly forbidden for any person to orawl into the storage tank vault, unless all the storage tanks are cold and all the low and high piressure atoan is turnod off.

(11) A large differential of steam and alr pressures ohould nover be allowed acrosa the pressure reducing valves. When operating on the by-pess of the steum reduoing valve, close the air valve leeding to the Foster valves so the pressure reads on the atoam gauge thout going to the Foster valvo. Speoial valves have been installed in some of the Travsfer roome to allow this to be done without affecting the Fostor lva.

(12) Nover oparate for any length of time using the condensate trap by-pass. This is dangerous in thet the high pressure steam nay got through to the conderasto line and al so the pressure of the sterm pushas the water into the condensate return tank and out over the roof.

(13) A1]. transfor room operators should know at all times which oirouits on whioh rack aro being operatod from a particular torage tank.

(14) Any unexpe oted change in storage tank woight and material, stean or air pressures should be notod as quickly as possible by the operators and $x$ eported to the liack Forerian, or if he cannot be foumd, to the Assistant Tochnical Suporinterident, of the Teahuioal superintendent.

(15) It is abeolutely nooessary thet onoh transfer room oporator should know the location of all valves and controls well onough so that each one can be found by the operator quiokly without delay, in the darleness in ases of an loctrio light fallure, or in a dense smoke in oase of a material break.

(16) Whenover stoam is tumed on the stam trap valves should be cheoked as to whether they are open or closed.

(17) No change is to be mado in the trangfor soom operating procodures and no valves are to be opaned or clossa on arder of any paople outside the transfor roon orere, exoept the Reok Foreman, Chlef laok Foreman or the Tochnical Superintendente.

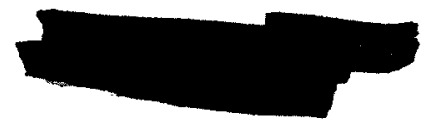


(13) Is spase time, work on eloming up the tronsfor room anc treanserre ing tasial. It is a good idea to label all spare equamert, link lines, hoses, oto. and hanf on the werils.

\section{Genoral Energonoy Instruotion}

In goneral, as in the oase of all of these operating instructions, omargencies as ise whon the operator is areiess or attempting to bo too hasty. The best emergenoy procedure is to follow the methods civon hore with oere und the emerronoles will not arise. In case of an coident in the trensfer room, the following steps should be taken, prefexably in the order in wion they are listed:

a. Put on faco mask, holding bresth until adjustod.

b. Close duot doors.

a. Turn on duct fan and ventiletor fan in room.

d. Turn on all water ereoze-off ling. (the water valves should be kept normelly in position so thet opening the one main valvo wil start 21 the $(200 \mathrm{zo}$ off mator flowing.)

B. Turn off high pressure stam on all storage tanks.

P. Flood all atorage tanks with wator.

B. Sond mossare to the rack to sroeze off top and bottom freaze off colls.

h. The details of any ecoldent, waterial bzok or low as well as all other operatione should be fully desoribed on the rak chant and in the transfer room $l o g$ book. 
Seotion 0. The Colume and the kaok

\section{Desoription of the Colume and the Rado}

The Fital process in the plant is brought about in the colum. The operating proociure, then, is to introduoe the material into the colums where the dosired ahange ooours. The raminder of the plant funotions to bring about the conditions whioh allow the columa to funotion in the moet offloient manner. A raok consists of 102 colume. but ince the oolums are identioal in construotion oolum
desoribed firat. The Colume

The oolum consiats of a niokel pipe about 48' long surrounded by oopper tubing. This tubing is then inserted into in fron jaoket maling three oonoentrio pipes. The intermal diemeter of the oopper and the extermal diamstes of the niokel aro seleoted to produce a cmall annular space betwoen the and $1 t$ is in this annular spaoe that the material is introduesd. Around the copper tubing is the gelvanlized treel jeoket. Stean at about 1000 pounda per square inch prossure and $545^{\circ} \mathrm{F}$. pasmen through the oentral nioleel pipe and provides the necesenary heat for the prooses. Water passes through the outer iron

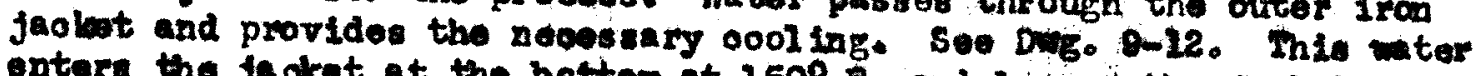
ontera the jeoket at the botton at $160^{\circ} \mathrm{F}$. and leaved the jooket at the top at a temperature around 1609 . having boen houted up by the heet from the seam paseing through the $f$ uid in the chaulap apaob. Theroforo, wo have a temerature differential of about $545-165-390^{\circ} \mathrm{g}$. across the oolum over its ontire length. Mhl temperature differontial is essential to the prooess and oamot be allowed to rary. The equipmont for controlling both stean and mintor is disoussed in another
section.

Construotion of the Colum

The 481 colum is not made $p$ of angle, continuous lengthe of niokel abd oopper. The niobel inner tube is made by wolding 24. 12: and 6' pleoes togethex. The copper tube is made by ailver soldering oopper sleove over the length to bo joined together and inserting a ring of silver solder in the recese in the leove. Bent is applied, the silver colder nolta and is dram by oaplizery cotien into the foint, this sealing 1t. At saon and of the ooluen a hort niokel Gleove is imilarly ellver-eoldered to the oopper so that the outer tube projeoting from the tar jaoket is aloleil, rather than copper. This arrangenent peraits the une of oopper in a large part of the colum and is desirable inoe oopper is mors oconomical then niokel and oun be febricated to olose tolerance wh these, but it atill allow the niokel tits to be welded to niokel. Inis is important ginos tho tolexunoe in the annular aproe is probably the noat aritionl in the entire aysten. The anmular apaoe is malotained by anall ajolos buttons which are epot wided to the inmer niokel pipe and oot as spacers. 


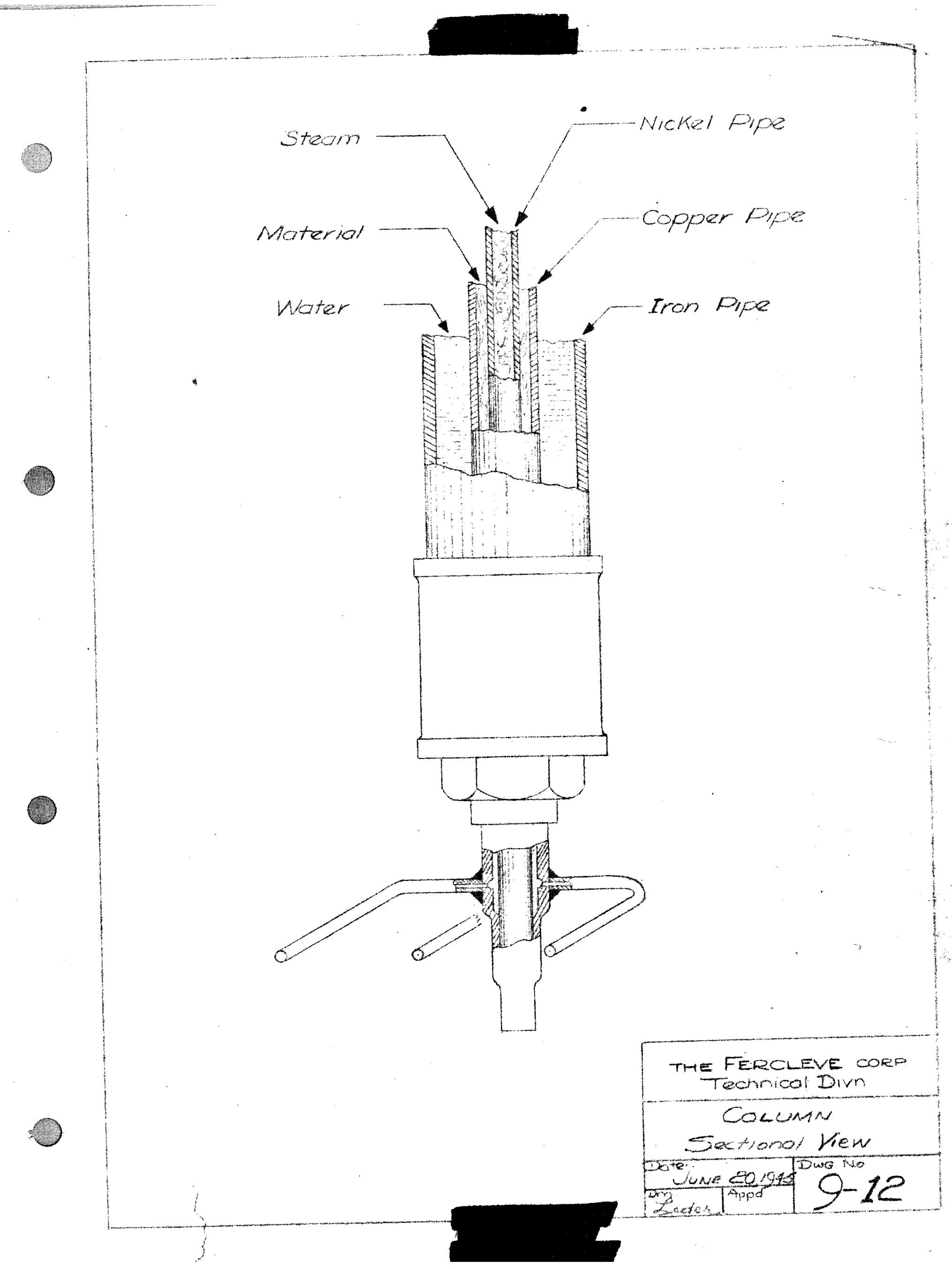


Copper is used on the cold slde and niakel on the hot, beounes the high inaide temerature would case low annealing of the oopos with coserquant roduction in mochanioal stroagth.

\section{Comeotions Betmeen colume}

At the top and bottom of eaoh oolum there are three anall nickel tubes wich project Eron oolum. These comaunicate with the canular space in the oolven and are used to introduce the material into the colum ond to ramove it from the colurm. One of these tubes or tits as they aro alled is used to repove camples from the oystom

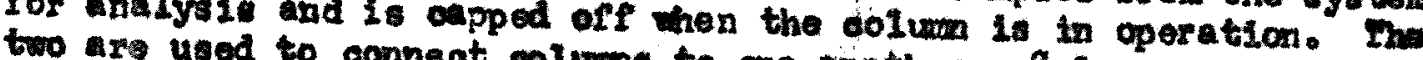
by intarool wo conneot colums to one another. Colum are competed are smill 80 that thoy oan bs

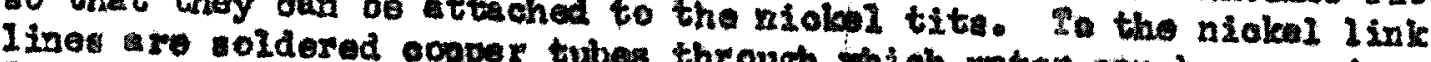
This in in offoot, then. tubes through which wates on be pesed.

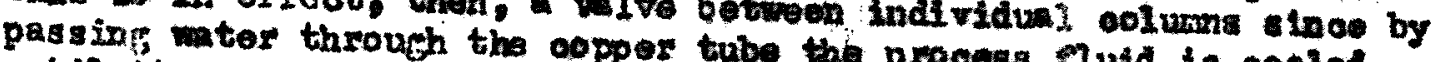
uatll It colidifies and a plu of the process Iutd is cooled tive plow of cluid. On turning of dauges the plug to melt. thus allowing vat the hast of the duot

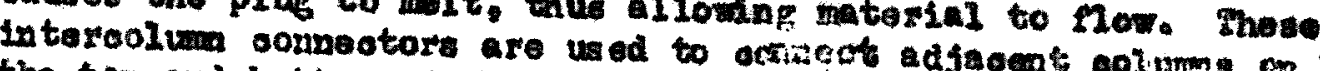
the top and botton of the rack.

\section{The Condust Syeten}

Alao loosted at various region: of the rack are other niokal tite wink are the ond of the oonduit I ines through whioh the waterial Il ow from the trankfer room to the raok. $\$$ condult I ines arranged in groupe of alx with 18 on en on 18 ide of the raok. In the group of asz the condusts on the and of en group in of larger dinweter than the other four in the group. rhese

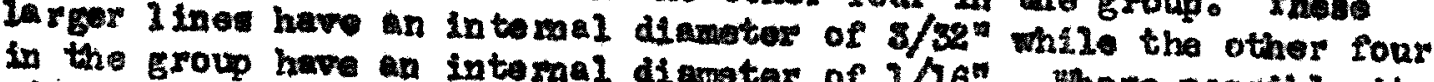
in the group have an internal dianotar of $2 / 16^{\prime \prime}$. The re posatble it is

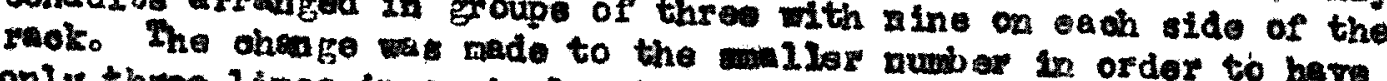

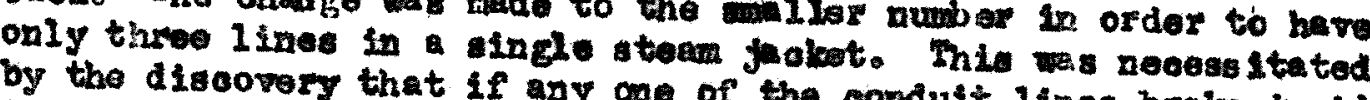
the oonduit the ateri al and its hydrolyeie products oofroded the

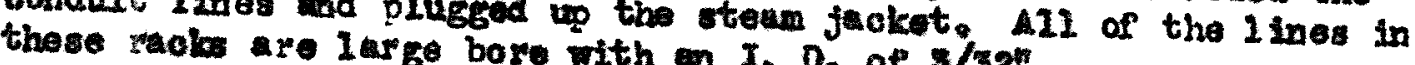
,

The laterial Circuit

The material itself flaws to the raok through one of the condulte. From there it passes through a viokel line or "fruper" to one and of the raoks At thie point, the niokel 1 ine 18 introduced Into the outer of ooll of $3 / 8^{n}$ copper tubing through which

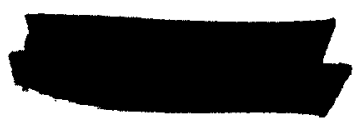


This arrangement is used in order to be able to freese the matorial between the condust and transfor rooms and the raok 80 thut in the ouse of an emargenoy both will not be emptiod. Fran the freeze-off coil the material is introduced into the side tit of the end oolum of the rack. me material then passes from the flret colum in the afrouit out through the niolel line in the interoolum conneotor and into the side tit of the next coluen and 80 on. The material thus follows airoult throuich the bottoms of all of the colume, filling the oolum which stands in the oir ouit like stendpipe. Placed in cerles with this oirouit somewhere in the loop is a convector system through which the terial passes and fom there it goes baok into the columa. After pasaing through the bottom of 25 or 51 colums it passes through apother froezemoff coil into another conduit through wioh the terial returns to the scale tank in the transfor room. Suoh a system of conduits, conveotors, columa, freeze off coils and jumpers through which the material oan olraulate is oalled a cirouit. Aotual detalls on the building of a ofrouit and rules to be followed are given in another part of this seotion.

\section{The Conroator Loop}

It was stated in the seotion on properties of the material that one of the important properties from the standpoint of the plant is the tramendous orango in denalty with temperature. This is important both in reapeot to the faot that fineing of lines must be done very carefuliz but also in the effeot whoh is utilized in the oirouit on the re?

The ten approximately $175^{\circ}$ and the tomperature of atoam at 5 pounds pressure is approxinately $110^{\circ} \mathrm{O}$. The density of the material at $175^{\circ} \mathrm{Co}$ is about $3.0 \mathrm{~g} / 00$. The denaity at $110^{\circ} \mathrm{C}$. is about $3.6 \mathrm{~g} / 00 \mathrm{c}$ This differenoe is 50 great that use is made of it in the system. The metarinl is passed through one tube wioh is heated b: 100 ib. steam and then through another whita is heated by 5 1b. stam. The tubes are loosted in twolve pairs of pipes with six pairs on each oide of the rack Since the donalty is less in the $100 \mathrm{lb}$. pipe than in the 5 1b. side, the terial $1 \mathrm{ses}$ in the $1001 \mathrm{~b}$. 1 ine ${ }^{2}$ falls in the 5 2b. In efving the puming aotion necesary to have the oiroulution desired. Fille the hole syeten is at a pressure of 1500 poinds or higher there is no differential in preseure except that given by this oonvection current oocurring in the conveotors. The total difference in pressure is of the order of only throe or four pound per square Inoh but is surficient in the system to keop the paterial floring around tho circuit. However, it is not sufficient to push any merial through the syetem if there is any type of reterial plug or constriction in the cirouit. For this reason, "plug-hunting" is one of the most important parts in the operation of the plant. A separate section is devoted to looking for trouble of this type.

Valvea

The essantial parts of the raok itsolf of interest to the operator are the colums and thaly connections, the conveotor aystem and the ineoze-off system. Seo Dys. 9-13 


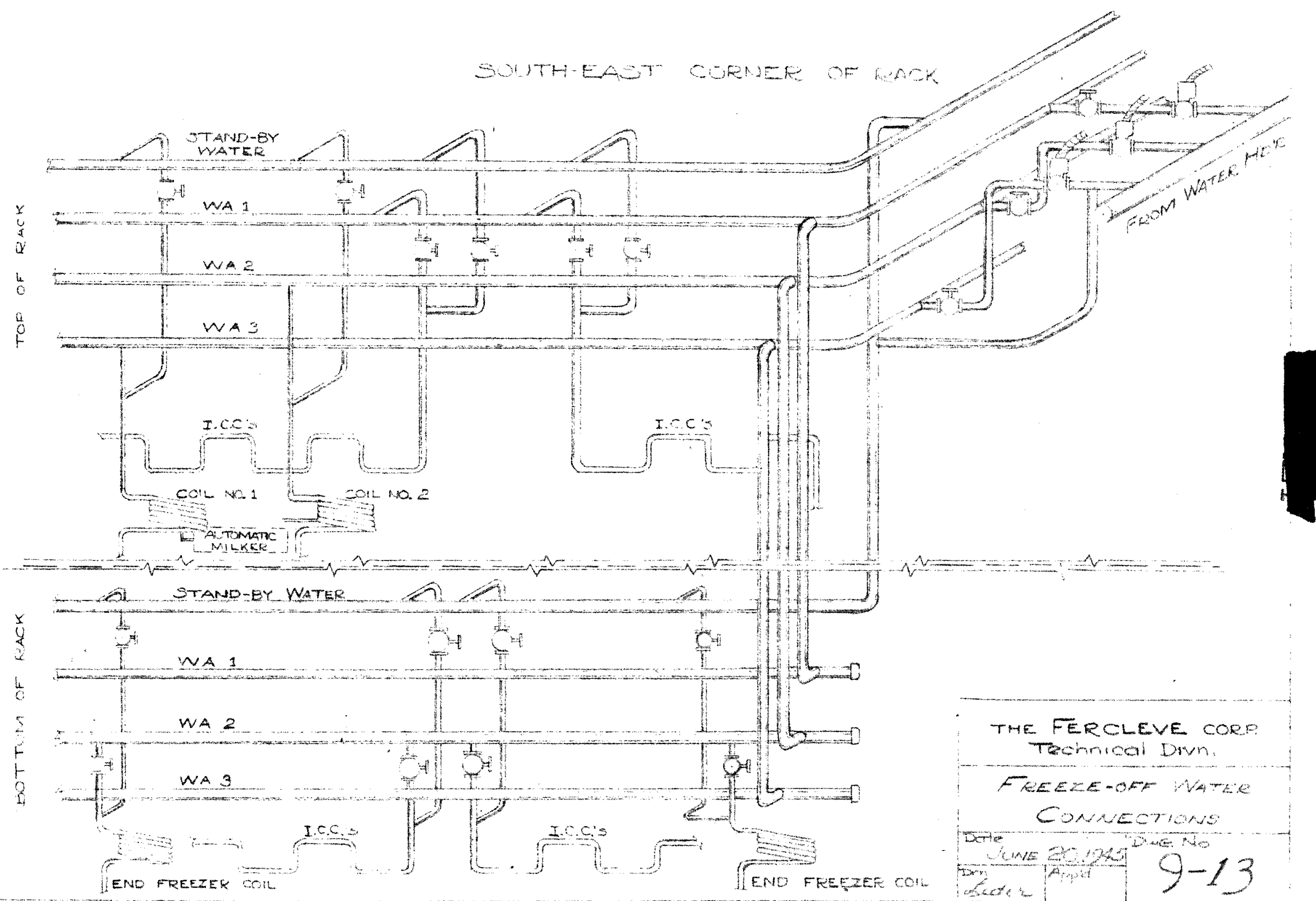


In addition to the parts of interest in the naterial nsten the solums have fiva val res on ach one. At the botton of tho rack is

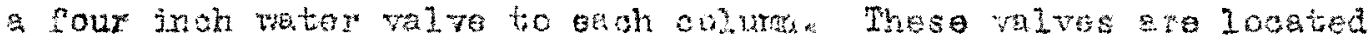
bohind the oolures ins lat the rack Arothos set of valves aro

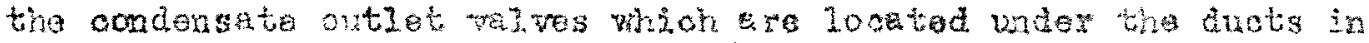

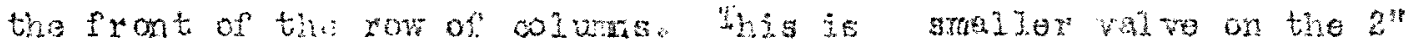

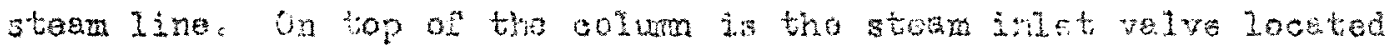
in back of the colura and inside the reck and taso a fout inoh water

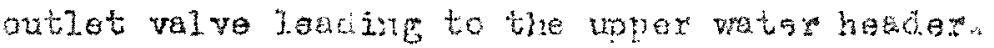

At the top of the wher outlet aloow is another ine runang

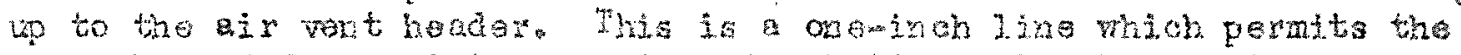
an relansed fron solution in the cinculating whter by the increase

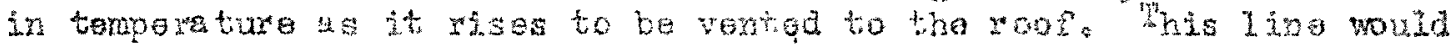

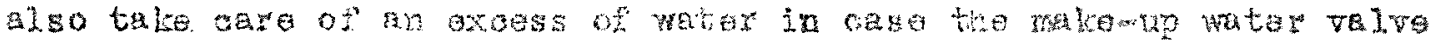
should opon and the syotam be unable to care for the hroross in

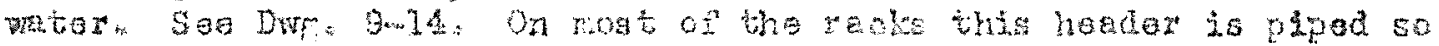

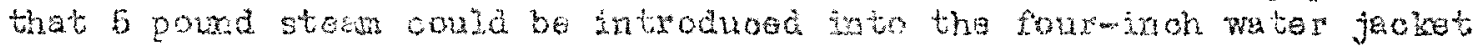

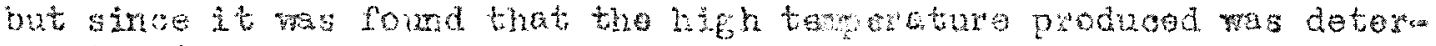

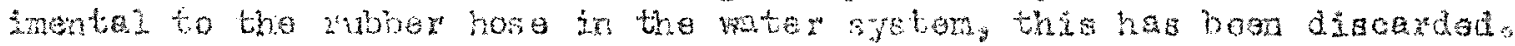

Other agpeds of the ok construotion such as the condensate

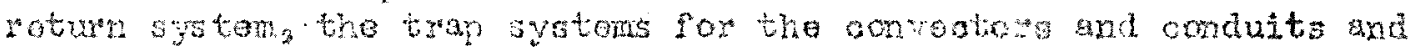

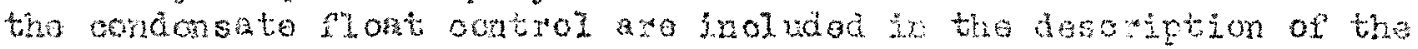

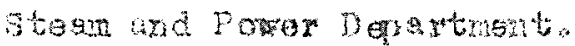

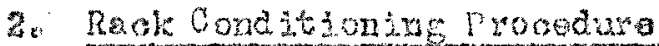

Introduction

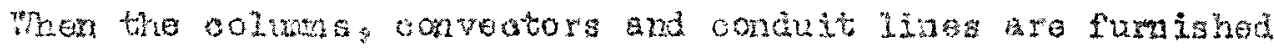

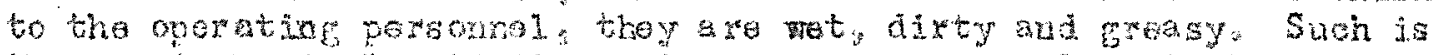

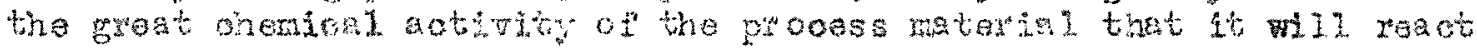

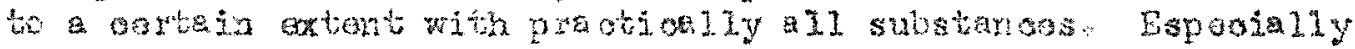
violamt and irrororsibio is the reaction with witar and oils. Among

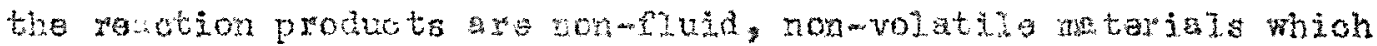

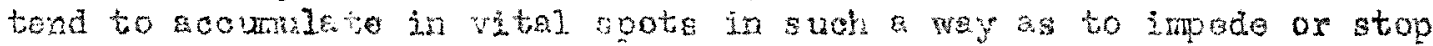
the flow of the ligoes: naterial. A number of the oonseoting link

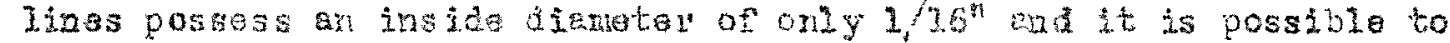
plug thase lines by the action of as 15 thla as iz fow nilligrams of

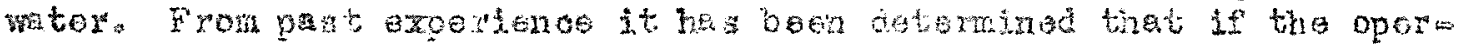

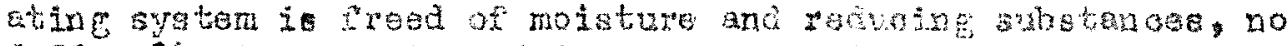

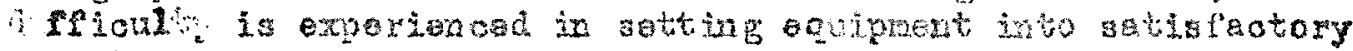
operetion.

\section{Priocipis of Conditionirg}

The conditions of motsture renoval must be partioulariy r gorous since these in a strong tondan for ail the nater in the system to oollect at a cold spot. These romakis lead also to the conolusion that it is assontlal that all omponents of the systam

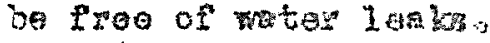




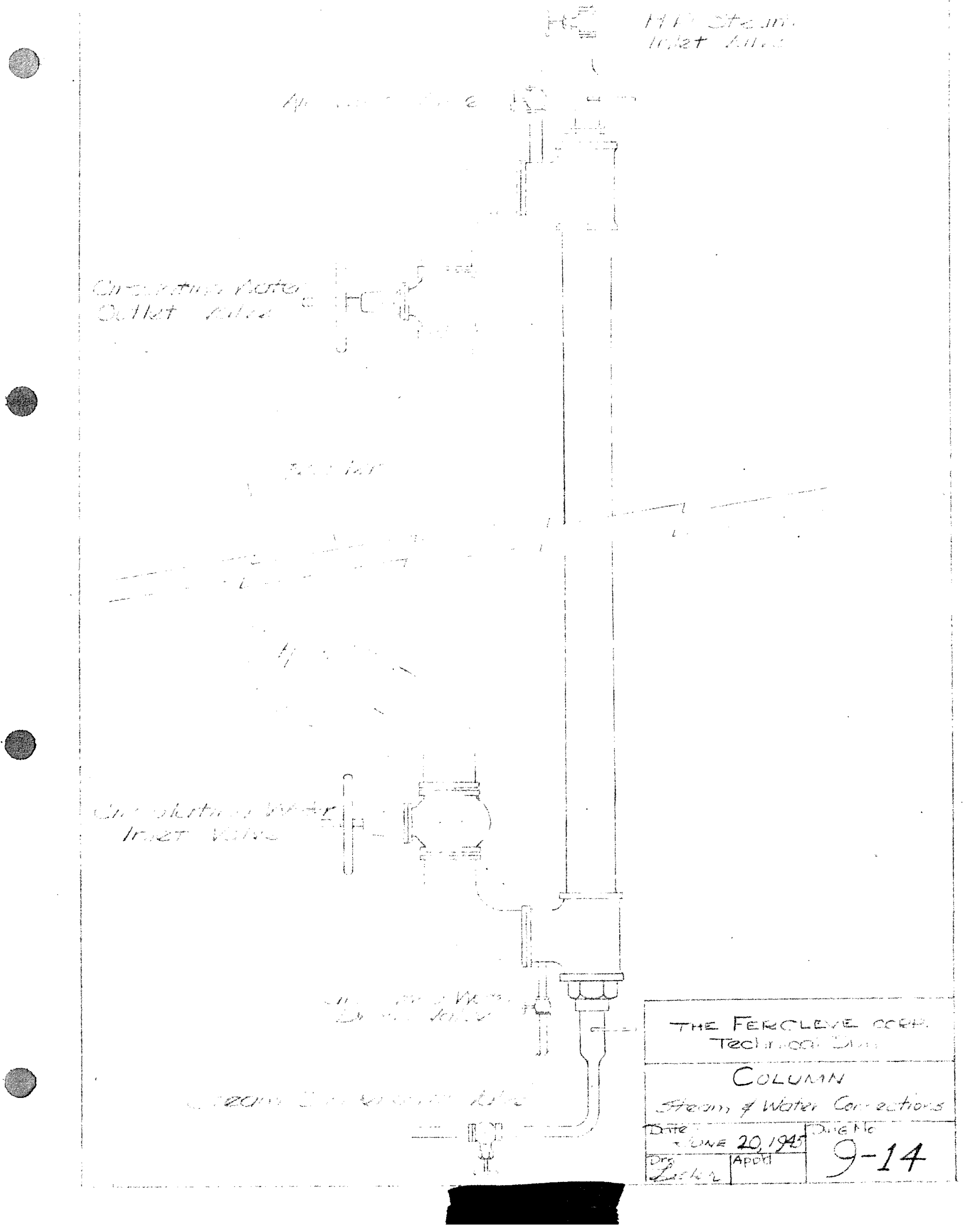




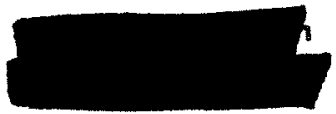

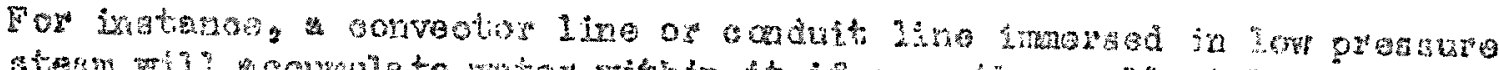

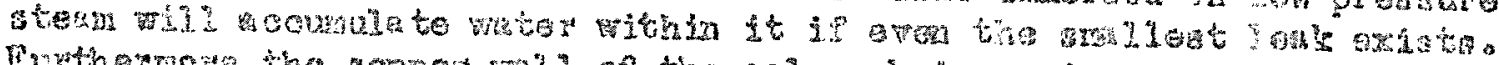

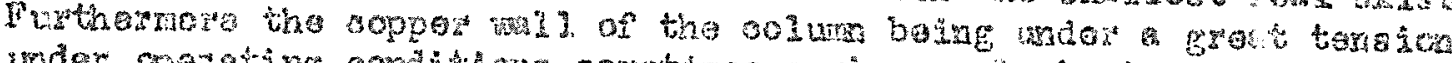

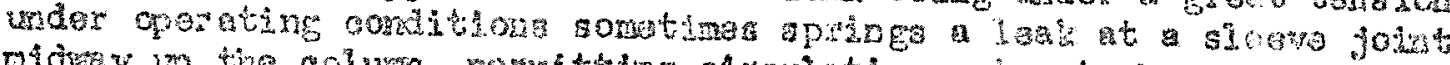

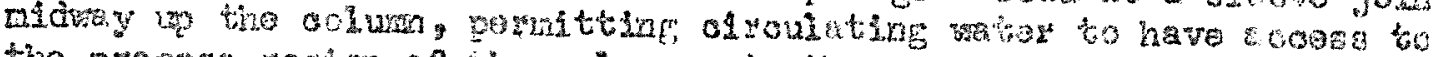

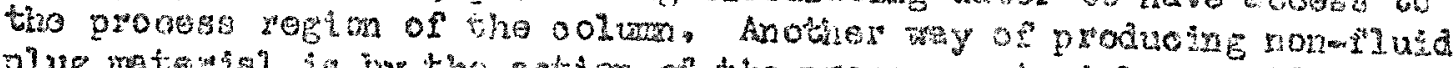

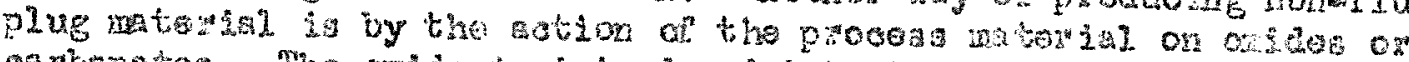

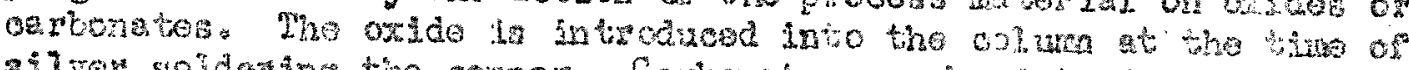

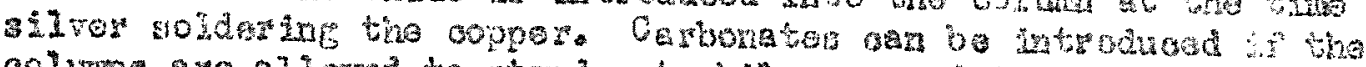

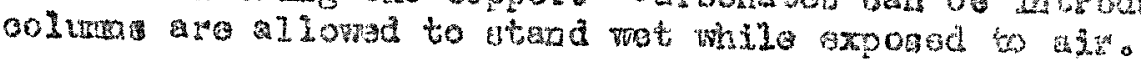

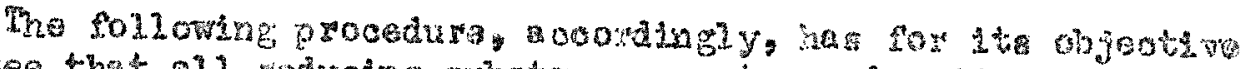

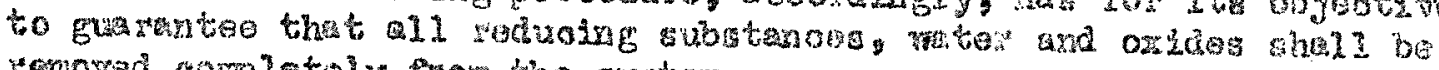

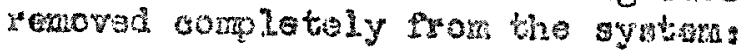

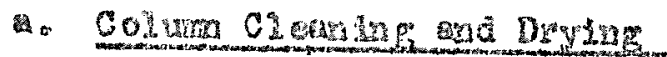

1. Biow nost of the notgture out of tho solume by

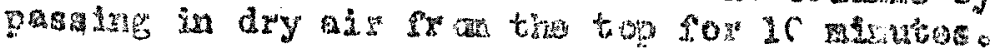

Fhis and all othor operations zarolring tho

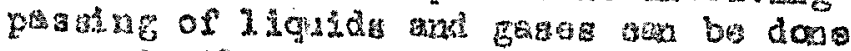
oontrententiy by wa of mand fold made from onpsy

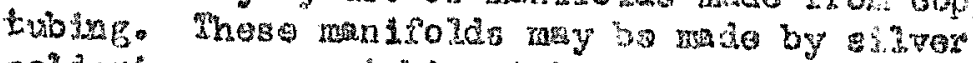

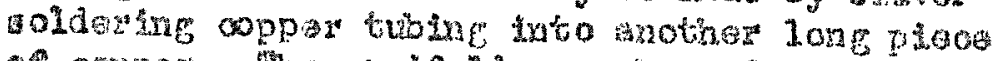

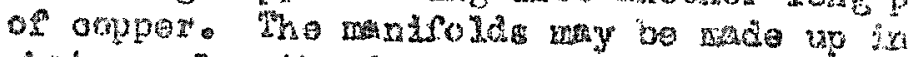

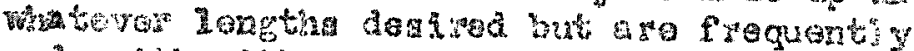

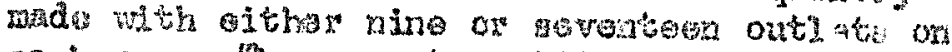

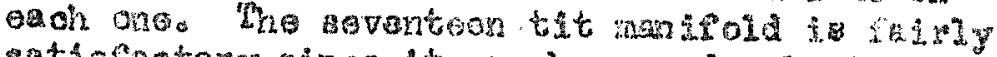
atsafmotory sinoe it on be woved anly thas to

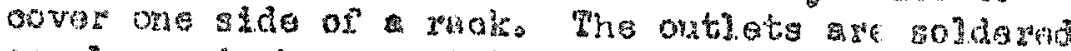

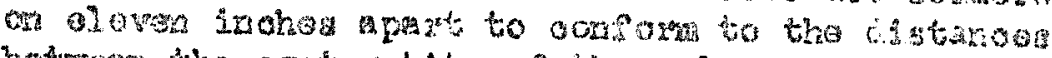
betroes the centar tite of tho solumas. Fis tho ond os the outlety a nokel two in soldtad on

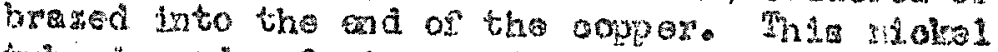
tubs ts made of pipe having an ortelde dicneter of

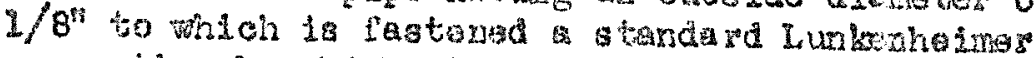

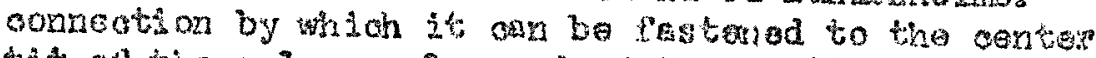
tit ol the onlum. One enci of tho waseard may be aoldened shut but the other and usue ly bs:

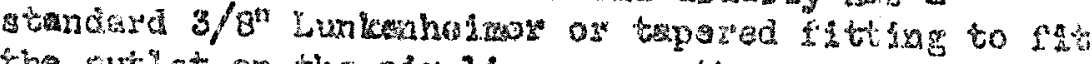

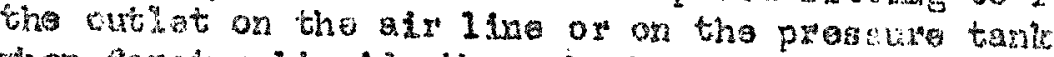

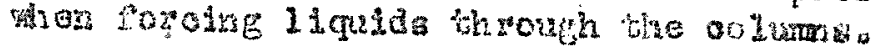

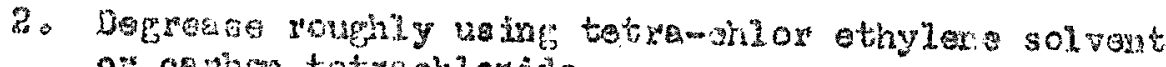

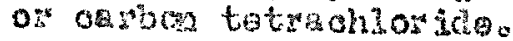

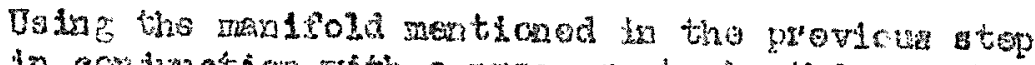

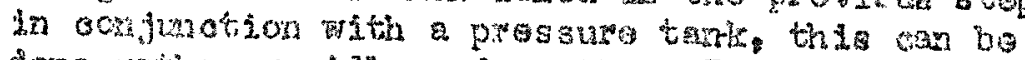
dono rather japldy and endiyo Tho prosure tont Is a rotel acibalnar having to ponigg with

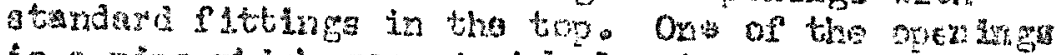

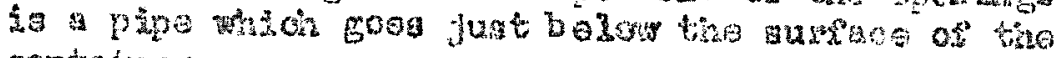
controtion 
The othos opening has attached to it a loager plpe reaching to the bottom of the tank. compressed is is foroed in ons openiag and whea liquid is contrinod in the tank will Pores the liquid out the second opening and up into the 00 lumer. Usualiy the tark is fitted with a gauge cor measuring the ais prosuta and a release velve to lot the pussure dow when auficiont Muld has pasaed thisough the oolumn. Usually ilgujd is passed through the colum uritil it appeal"s to be olean. Pase the fluid from the botton to the top. It is usualy satisfootory to pase about onemalf pint through oach of the 3 top titio.

When reok is degreesed blow out the colwing wh the aly through a manifold from tho topo opan all titis a

3. Toat all oolums in the raok with 10001 b. steamo

The cifseronce botreon the stoan and the ofroulating tomporatis should be bout $400^{\circ}$. Tho objoot of this atop is to siabjost the colume to the stresson whio they wiI encounter durizg norral operation. Initielly some wer vill blow out the botton tits in the forn of a mixture of water and steamo jowevor, if this molsture continues to is sue fortin tho colure is undoubtedly bad Usually abou' one out of every 200 colume has falled during tis

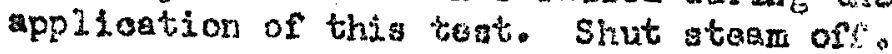

4. Lake a final and caroful solvont was usiag alean zol veat and passing flusd through sil top titis. Crack bottom tits unt 11 iqujd is clan. Drain fluid back into the tank.

5. Atiach manifold at top and blow out solvent with air for 10 minutes.

8. Wash the oolume rith dilute hydroohloris aosd.

This acid is macio up in the approximate itato of asx parts of wertor to one part of oonoentrated acido This atep is usually dono by foraing the oold up tho oblums with the prosaure tank and ool looting the acid at the top of the raok. The usial methed of onllooticn of tho aod or othor lichuic 28 to atcuoh ahort length of rutber hose to the tit and pass the nujd into a injlk bottio. 
Shas andisa one to deterning if the pusd is ooming through doan. The oloan acid nsy bo usec. agrain but any dixty acid should be dis.. sarelad.

7. Wash the nolums with woter until the werter ia clas: collowing the sara procodure as with the hytroointorio acid.

8. BI out wator with air for sive to ter minutos. Oper all tits to deternino is they are open to

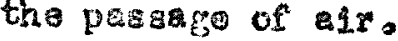

If f'or any reason oonditioning proceduros: zoust. be inter'y upted at this point, the colume should be Pushod th nitrogen and sappod. In general, any intorruption of the oondition ing prosedure should bo aroided partioularly between the bine whar the oolum is first wot with golvent; and the tifo it iv filled with nitrogon. Do not plew tho mork so that any of the oolumas a le fit moset and with air in thon for any appreojeble longth of tilas. If the colums are loft wet fo:" as long 20 wht howrs, they should bo reconditionod stayting with the acid rashing stop.

8. To start the drying proodur, trach gtom tracod copper maniold to agoh of the fours chroutto of the raok.

See that the duot hoating stam is on anc that the 1000 Ib. Bteam ia turisd on the reok. 01080 the duet doors as fal as possiblo. Adjust the of roulating wat tomparature to $150^{\circ} \mathrm{F}$. Tho stoan treoed man ifolds 025 outblot manifolds which have another line soldered to the ris in socition of tho mentfold. This is oonneoted to - Lor pressuro ston 1 ino and is used to heat the manifold so that drying may be facilitatod.

10. Eraute the system for one hour with the top middse tit of anoh colum laft unompod.

The purpose of leaving one tit unoepped is to 213 of a to atrean through the colums: thiza 8woping out the gross anount of wher ard water vapoi left in tha oolums after the wetor washing
trobment.

12. Evacute for two of nne hours with 6.1 th the tits capped off at a vacuus of 27 inches or mora.

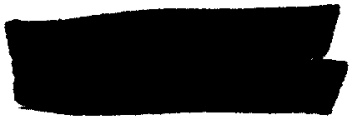


If 81 ight leaks axist in a cirouit, it is unimportant at this timo. No effort need to bo made to looate mino leaks until the freshlair
troatmont.

12. Disconne ot one side of each intercolum conneotor and oap off the tit and link line at both bottom and top of the raok. Remove manifolds.

The purpose of this ster is to isolate each oolumn. This stop is unnoosasary if the intercolurm connootors have not yet beon installed.

13. Attach o oonootion from a nitrogen gas oylinder to the middle bottom tit of the first colum of the oiroult or to the tit from wioh the inter oolum ocnnotor ras romored. Attaok to the top middle tit of this first oolum a rubber conneotion leading to a glass trap immorsed in liquid nitrogen.

The trap must be attached befor o any nitrogen gas has been blown through the oolumn as the plan here is to be able to trap water or water vapor which has acounulated in the 01 um in order to magnify the test. The oolumn mist have stood at least on hour after bringing them up to tmospherio pressuro bofore making this moisture test.

14. Blow nitrogen gas at a pressure of 5 pounds on the ayl inder gage through the colum for precisoly on minuta.

15. Inspeot visually the moisture oolleoted in the glasa trap during this ono minute tost.

16. Rocord extent of frost formed or noloture colleoted giving a rough ostimato of the amount as far as possible. Repert the test for all the colum of
the oir cust.

The outside surface of the glass trap must bo wiped free of frost with a dry oloth bofore making this observation.

Oooasionally, it is atisfactory to do this test using two oolume in oach testo If this seams to be bad the test should be run on each of the oolume.

17. Isolate any susploioue colums by instelling bypasses with water freozemoff Iine attaohod. 
18. In onse of doubtivl oolume, isolate these, lot stand for six hours and report the test.

19. Conneot or re-conneot intercolum conneotors.

20. Make a moisture tast on the colum ofrouit by the following aitrogen mothod for thirty minutes.

For datalis of this teat sea seotion on Molsture Teats.

21. Whilo stop No. 20 is in progress mako similar molsture test by the mowing, nitrocen method on tho oonvootor and oudiuit systern.

22. If the molsture tosts of the difouit and of the conduit and oonvestor loop system show $108 \mathrm{~s}$ than $0.05 \mathrm{G}$. conneot the two together and vrouste to 28 inohos.

23. Fill the whole aircuit with freah air under prossuro, test for leaks, ropalit any bad connootions and by-pess top and bottom any colume wth lonks in the wolded joints.

Fresh a ir leaks may be tested for by one of throo mothods:

\section{Tosting for Leake with Eragh AIr}

(a) Allow 111 uminating gas to strem over the oomeotion from unlighted Bumsen burner. If iresh als is present in large enough quantitiea, the gas will bo ignitod.

(b) Tie a cloth rag to one end of a metal or wooden rod, soak the oloth with concentratod ammonis and probo about the rrolded joints of Junirenhaimar connections with the rag. If the frooh ais is lasking out, white fumes should indioste it.

(c) Lay about the weld or connection a spocial ohloride indioatint test pepor (obtained from the ohemioal storeroom of Labo:atory No. 2) If frosh ais is loaking outy the paper will turn brown or browish blue. This test is particularly good for locating the exe ot spot of a leak. 
In tooting for loaks, be sure that all lunkonhelire connections aro tested as well as all wolded joints, the later where the tits are welded to the colums and where the inside ond outside oolums are welded togother: Bi iure to test both top and botton of raok as 11 as the oondust and ocnvestor loop oonne oticns.

b. Cooduit Line Cleaning

1. Condult lines should bo rough dried by blowing ais through thom.

2. Lines should be degreasod using oarbon totraohloride or othor solvent and the solvent removed by passing dry nitrogen through the 1 ine while flaming the tits at the terminal boxes on both onds of the condult.

It is neoessary that the oonduit be tegted with 5 pounds stam during thic prooedure.

3. Conduit lines should then be oeped on both ond and sllowed to stand for 24 hours with steam on the 1 ine.

4. At the end of the 24 hours a test for leak oan be made by introduoing dry nitrogen at tho transfor room torminal box and running a molsture test qualltatively. Great oare should be employed in this step sinoe number of oonduit ines have bean found to poskess water leaks.

When not in us all conduit Ilnes should be left unsapped.

C. Clooming of Convsotor Lines

The proosdure used in oleaniog the convootors is essentially identical to that amployed for the oondust lines.

d. Cleaning of Link Inos and Interoolum Conneators

1. Lines are dogreasod and Iloy tegtod with greaso solvent.

2. The solvent should be blow out of the J. ines and conveotors and placed in the hot enbinet in tho materials shop. The tempelature of thin box should be naintained at a rinimam of $120^{\circ} \mathrm{C}$. 
3. Iffter remaining in the box for one hour the lines should be bl own out with dry altrogen and oapped.

\section{Operating Instruotions for Rook}

\section{Comploting the Metorinl Clroult}

At tinss stere the various oomponent parts of the reok heve been cleaned and dried. They should now bo cenve oted togather with great care being taken that no mosature bo permitted to ger into the syatom. The conneotiona up to tiro transfor room duot and inoluding a 11 links, intercolum oonneotora and oonveotors should be made with the orientation boinf that dosired for the oporation of the rack.

1. The conduits showld be chosen from among the list found to bo open in the aleaning prooedure. The two ond oondulits on ach terminal box should be usad tyere posaiblo.

2. The link Iines should be obtained from the conditioning shop of the oorreot 1 anth to reagh from the teminal box to the ends of the oircuit. It is oustowary to haves 26 colums in a siroult but thore a se soverel speoial oases were this is not followed throughout the plant. This would make four oirouits per rako

3. The freeze-off coils should be attached to one of the ond oolumns of the oi rouit. on the otiner end the freesemoff coils should be tteched to the $100 \mathrm{lb}$. ondreotor.

4. The convestor loops hould be placod at the snc of the oirouit using 1 ines numbra 2 ard 3 vinenever possiblo. The conveotor loops Bhould be set up so that the fios proceeds from the low numbered colums to the high numberod colurions. For top olroviation syaters the flow should be from high numbered ool unns to low numbered colums alone the top of the oiroult.

5. Every cirouit should have flow ind loator equippod with the roometar wells and thoimocouples wherever possiblo.

6. Provisions should bo made for evacuating, the systom and introducing fresh ait. The raok should be purqed to a vacuira of $28^{\prime \prime}$ and frosh alr passed into tho syatox to a pressure of 10 lbs. The gas should be bied from all top center tits sad at the terminal boxes both on the raok
and in the transfer room. 
7. If any dolay is to be encountered in sotting the raok into prooes operation tho equipment should bo left with a positive freah air pressure. It is highly desirable to start prooess fluid flowing in immodiately after fresh air troatmont has been oompleted.

b. Starting-up Procedure

2. Check al 1 valves. Be sure that all stoam, water, and air vent val ves on the oolume are open on all the oolums wioh are in the oircuit. It is ueual for the stram to be turned off from oolumes out of service but not the rater valves.

2. Make sure that the oirculation water is flowing. This should be done by the Steom and Power Department but the operator s should always ohook to make oertain that it is flongo

3. Have the steara turned on through the by-pass and bring oiroulation watos temporature up to $1500 \mathrm{~F}$.

4. Have the in ateam valvo opened and bring prossure to 1000 pounds.

5. At this point colums should bo oloan, dry and full of fresh air.

6. Chook to see that all tits of 211 colums have oonneotors or caps on thom and that these are tight and not orossthreaded.

7. Cheok to see that the freezow of water system is ocmplote。

8. Chook to seo that hook-up is oomplote and that it oor responds to diagram on ruck sheot.

9. Check eapeolally to see that oonveotors and condult lines are correotly oonneoted. A common mistake is to connect to one line at ane ond and to some other conreotor or oonduit line at the other.

10. Cheok location of thermooouples。

11. Cheok duot temperature to seo that it is above $80^{\circ} \mathrm{C}$.

12. Cheok conveotors and condult lines to see that they are properly hot.

The raok is then ready to be fillod or roady for operation. 
4. F111ing the Reok

- Flling from the Transfer Room

The original method of filling rack with prooess material has been largely supplanted by a more rapid wothod which requires less manipulation of equipmest. Both methods will bo desoribed. The first mothod whioh is that of filling the raok from the transfer room is more fully describad in the Seotion on the Transfer Room sinoe it is essentially transfor roou operation.

In following this procedure the raok has the oomplate olroults hooked up with at least four gauges on the rack with two at the top and two on the bottom. Ihe freeze-off whor is not turned on the top or the bottom of the raok. When the truafer room storare tani reaches a pressure of 1500 pounds material pressure, the storage tank tits are unf rozen and the material is ellowed to flow through one of the conduit $I$ ines into the raok. Tho oisoust being filled usually exhtbits the phexomonon of "pitohing". "he lin problem involved in the filling of a raok is to get the waterial into the 001 uns as rapidly as possible to out down the time which the oiroust pitohes. This frequently takes place quite rapidiy with the ofrouit filling in an hour or $168 \mathrm{~s}$. Howerer, it is often the oase that because of improper conditioning, a plisg of hydrolized material is formed in intercolum onneotor whioh probibits the matorial from flowing any farthor. Wsight-t tno readinge should bo taken in the transfor room and whon the wolght stope falling off It may be assumed that the ofroult is no longer boing fillod. A oirouit 111 usidel Iy tako betwesa 90 and 100 pounds before being pressured wh high enough to stop pstohing.

\section{Pressuring wo Cirouit}

If the weicht stops dropping before this much has come into the circuit, it is probeble that a plug oxiats. The location may frequently be ohooked by finding out where the oiroult stops pitohing. If the material is being put into the oircuit from given condust $I$ ire and the oircult pitohing, for examplo, half way down the olroult it is probable that plug has been formed in that neighborhood. The usual method of proosdure in this oase is to obtain niakel fumper and attach it from the oenter tit of the colum whioh is pitching and attaon it to the oentor tit of another colum thich is farthor down the oiroult thus by-passine the intercoluno connactor. This will frequently allow the material to flow into the other part of the olrouit and complete the filing of the oirouit setisfiatorily.

It is common pratice to place a gauge on the oonduit line in the tronsfer room which is not being used to fill through and notica when the pressure is up to standard on that gauge. 
In other words, if a oirouit is being f1lled through one conduit and the material flors a round the oirvuit until it pressures up the gauge on the other end of the oirouit. It my bo as sumed that the oirouit is full of material. It may bo neoessary to raise the pressure to $1700 \mathrm{pos} . \mathrm{i}_{\text {a }}$ to get enough pressure to stop the pitohing but it is very desirable to have ocatact with the scale tank so that this ma be transmitted through the oiroult as soon as possible。 The steam consumption of a of rcult whioh is pitohing is usual ly about twioe the steam consumption of oircust whioh is not pitching. When the pitching stops, indicating that the oi roult is filled, the gauge may bo disconnected from the ond of the conduit and the conduit may be hooked to the soule tank with a nickel jumper. The freeze off water should be turned on the top of the raok and tests for oi rculation may be begun.

b. Filling From the Floor of the Prooess Bullding

This method is used extensively sinoe it is ocmsiderably more rapld than is the other mothod: It oonsists in assomblying transfer pot containing a shipping tank on the floor of the build ing. It is hooked up with a Iine which oan be oonnocted to the 125 pound steam system on the rack. There is installed a steam pressure gauge and valve on the upstream side of the transfor pot and a line for condensate removal at the bottom of the regular pot. This is fittod with a tean trap to build up the prossure in the tank.

\section{Transferring}

It is oustomary to use large nlokel tubing for the material to flow from the tranefer pot into the reok. The tubing used for this usually has an outs ide diameter of $1 / 4^{\prime \prime}$. This is conneoted to any oonvenient oolum and the pressure turned on into the tranafer poto. When beginning a transfer from a full tank it is quite inadrisable to all ow a stoam pressure on the tank of more than 15 poundso This ill permit the material to melt in the tank without any danger of reaching excessive presisures.

After 20 or 30 pounds have been trins forred into the rack the steam pressure may bo raised to any value which peimits fairly rapld flow After the lemoval of several pounds thero is no danger of having anvthing but liquid matiorial in the tank so the only oxpangion that takes place 1. that depending on the increase of vepor pressure with the inorease in temperature.

Completing the Filling

Using this system it is possible to put 70 or 80 pounds of material in the oi rouit in this minner. It is not isually possible to fill the raok conplotely in this way ince the temperature 7 is such that some 
pressure is exerted in the beokwards direotion to the flow. Consequentiy, It is uavally necessary to prosense the system from the trapsfor room in moh the came way as the other wathod of fliling was finlohed. In this mothod the oonduitio are not atteohed to the storace tan $x=$ whon the material stops coning over from the tranafer pot on the floor of the plunt the pot way be d180onnooted. Whep the pot is disoonneoted, the ocndults should them be attaohed to the 8 calo tanke in the transfor room and the pressure raised in the same muner as was done wen the or iginal fliling was dowe in thit moner. This method is more satisfactory partioularly beoause the number of plugs formod seems to be much leas than when the other mothod is used.

\section{- P1lling From the Top of the Rack}

Mi2e this mothod has not boen uad, there ioems to be nu good reason thy additional advantages should not acome by filling the raok from the top rather than from the bottow. When the raak is nearls full after filling from the bottom the is a back prossure caused by the holght of the terial 2001 um in the raok which probably asooute for the faot that it is not completely f111ed.

It would seem that this oould ox iminated by moving the installation from the floor to the top of the reok thus eliminating the preasure foroing the material book into the poto It would be poseible to make the same onaneotions at the top of the raok as the bottom and th1s method seoms to heve some possibility of development if a oomplete oirouit rueods to bo Pilled.

\section{Looating and Eliminatiag Plugs}

Introdintion

By the work "plug" woun any obatruotion whioh prevents the prooos $\mathrm{fl}$ uid frora flowing through 1 ts normal oiroulatory sys tem. In addition to this type of 801 id plug there may exist "partial plurs" Whioh hinder the flow rather than atopping it ontirely. The proos that partial plugs orist is mesoh less diroot and convinoing than the ovidende for oomplete abstruotions, but it is reasonsble to suppos that sediment may oolleat in gpots, slowing the rato of ofrculation, or that solid plugs ra form gradially and constitute partial pluge before becomiog oomplote $021 \mathrm{~d}$ pluge.

The genepral problem of deteoting, loceting and el iminating plugs in process oiroults is one of the most important encountered in plant operation. for unless a airouit has many houre of good oiroulation overy day, it is not operating at peak of fiolenoy. 


\section{Formation of Plufs}

Pluge may be formed by an of the following mothods, but littlo can bo written at the preesent time about the details of plug formation, as the mochaniam of the forming of pluge ia in many cases obscure.

\section{(a) Chllling of Prooess Fluid Lines}

As the process Iluld solidifles at approximately $70^{\circ} \mathrm{C}$. at the oporeting material prossures, it is obvious thet if the temperature of any seotion of the fluid in the ofroulating system falls bolow this value, the material will solidify, thus forming plug and stopping ofroulation. This type of plug is the nost frequently oncountored and, fortunately, the most easily remedied.

\section{(b) Hydrolysis of Proosss Fluid}

L1quid or gaseous process fluid coming in contaot with liquid water or water vapor rapidly reats with the watior liberating an aold and produoing a high melting, solid whioh forms usually an immovable piluge Beoquse of the diffiouity. great difficulty, in dryine completely all the columa, intercolum conneotor and other component parts of the oirculating system, plups of hydrol 1zed matorial us ually ooour chiefly in the initial fillinf of a oirauit with material. Once alrouit is in good operating dondition with no internal water or stavin leaks, no piugr oan bo forred as a result of reaction with wher exoept when the oircuit is operied to the atmosphore. Even in this arse there is no danger of plur of hydrolyzad material forming if the propor precautions aro taken in preventing water from oondensing in the exposed opening.

\section{(a) Acoimulation of Sodimont}

Detalis and reasone for the formetion of pluge iy the acoumulation of solinont are littio known at the present timo. Inasmuoh as plues have aparently formod in oertain cases fos no obrious oxtomal roason, it is bellovec that: these plues must hava soon bullt up by tho acounulation of sediment. The nature of the seditont hus not voon detarminod.

\section{(d) Reaction of Prooess Flutd With Ormanio Matter}

Sedimet and plus formed from this sediment ars ocour When the process fluid reacts with or cando mater. In fact, any chamical roatica of the material will form plurb. 


\section{(o) Welding Shut of Joints}

In the originul fabrication of wolded foints or in the later repais of such jolnts, the weider has oocasionally wolded suoh joints oomplotely of nearly completely plugged up with metal. The only ouro for suoh aooidents is new joint made by a good weider.

\section{Proof of Plug Exiatonos}

\section{(a) Pltohing Test}

If pitohing is ocourring throuphout a ofroult at the gamo time that the material pressure in the scale tank aupplying the oiroult, is up to the normal operating value, then it is lnowa immodiately that at least two plup, exist in the oirouit, that both condusts or their as soolated oonneotions are plumed, otherwise the high nressure of the material in the solie tank would be tranenitted to the raok and the pitching stopped.

\section{(b) Ceroulation Teat}

If oirculation in olroult stops, if there are no opon conneotions, and if the copveotor loops, conduits and interoolum oonnoctors are up to temperature, the olroult so plugged. As it is not always evident whether ciroulation has really stopped or not, the methods for testing for the presenos or absenoe of olroulation shall be disousad here in ano detail.

Observe the Eof fman Flow Indloator for indloations of temperature decresise across the meter in the correot direotion for flow. At the bottom of the olrouit the flow in the plant is alway. from low to high oolum numbers and at the top in the reverse direotion. Insomuoh as a sl ow surgo of material in to or out of one ond of a plugged olroult may give rise to an epparent flow in tho oor root direction for approximately 15 minutes, it is nojossary to watoh the Flow Indicator over a longer period of time than this. If the temperature difforenoo remains ateady in the oorreot direotion, oiroulation probably exists. If tho temperature differenco ohanges, oven golne negacive in many instances, ourging, not roal flow, is occurring, or perhaps a surge superimposed upon weak fl ow. These surces are partioulerly notioeable at the monent of starting up cirouit.

There y be acther cause of misinterpretation of the Flow Indicator readings. In certain cases the thermometer well of the Flow Incsator on the left may not be located with respeot to the tit to which it is attaohed in exactly the same way as the thernomoter woll on the right, thus leading to an asymotry in whermal condustanoe and a difference in the temperature readings. 
Such as $A T$ is not only usuelly 20 , but the tomostature itsalf is also low and only alightly highor than the duot
tomperature.

When pltohing or hammering is ocourring in the colun to wich the llow Indlastor is attaohed, the thermal offect of the eiroulating rlow may be antirely maked by virtue of the rapid osoillation of hot prooess fluid through the klow Indicator. In this case the meterial pressure in the oirouit should bo raised until the pitching and hamering stop. The observations for flow oan then be made.

ag follows:

In sumasy the criteria for circulation oan be ilsted

(1) i on Hof'man Flow Indicator persisting in ourreot dizootion for half hour or nuve.

(2) Contigtade temperatures on 1 ower aide $150^{\circ}$ or higher.

(3) $\mathrm{T}$ equal to 30 to $50^{\circ} \mathrm{C}$. whon lower tamejeture is in the sejghborhood of $150^{\circ} \mathrm{C}$.

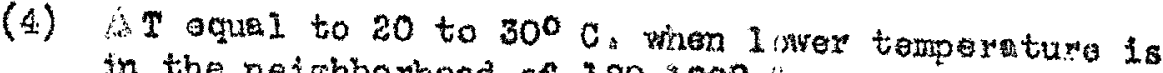
in the neighborhood of $180-190^{\circ}$,

(5) Liot side thormoouplo temparatuxis 350 to $400^{\circ} \mathrm{F}$

(6) Deorase of $T$ to neary anso whin the airouit is frozen of and the of roulation puposely stopped. If no deorease oocur's to the ol when the oircuit

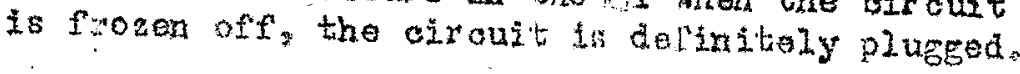

(c) Elinination of Cold spots

After it has becone certain frin the abuve oriteria thet no circulation extsts, the nexi; sten is to searoh for and to eliminate any rulatively colr spotis in the circusto Possible loortions are as follows:

(1) Cold duats, partioulary at tho nde which in cold weather should be shisided fin linafts by tarpaulins. (2) Cold spots sorred by drents through holes in duot

(3) Gold duots due to water dxipping on them shield ducts from the tor or stop the water loak。 
(4) Cold condustis. Cheok oondult stoan prossuro, valvos and oondensato dreins.

(5) Cold coaveotor loops and cold jumpers botwoen loops. High tamperature should be $270-180^{\circ} \mathrm{C}$. erature $105-110^{\circ} \mathrm{C}$. Chook steam prossures, valves and traps. Flamo jumpers.

(6) Link lines touching cold duct doors, of cold copper freezowoff lines. Change postion of link lino to iroe position.

(7) Coid Iink 1 ines due to. Wer dripping on them or to stoam bl owing on them. A bed steam loak into the duot may seriously affect ofroulation as a reault of the corbination of expending a tean wot vapor.

(8) Cold guots, Iink iines or tits in Transfor Roomo Heat link lines and tits with fleme Chook atem pressure, valves and tiap or duot heating Iine.

(9) Intorcolum conmootors or transfer room tits oooled by freezemof pator leaking pagt alosed valves, or by water backing up common drains.

In fluming link linos oare should be taken to begin the heating at on open ond and then to work slowly along the lenth of
the lino.

It is only after oliminating all of the above oold spots in a oirouit that non-fusible plug oan bo assumed to exist. The next serios of steps in plue el inination can then bo taken.

Detoction and Elimination of Plugg in Conduits and Conveotor Loops

Tho firet stop in looating and eliminating plug is to tost the condusts, conveotor loops and assooiated oonneotions to make suro that thoy are plug-ires bofore beginning the difficout operation of trying, to lookto and eliminata pluge in intorcolum connootors. However, before any atual work is done on the raok the history of previous rack operations should be recoived inasman as hints as to possiblo plug losation might bo obtained. For example, if the scalo tank on ofroult had just boen shanged before oi roulation atopped, one would suapeot the plug to bo located in the link 1 ines, conduit and soale tank tits involved in the tiranefex. Attention ahould, thetefore, bo foousad first on this looation and these link lines and tits proved to be clear before rorking on other soations of the
material flow system. 


\section{(a) Eressure Variation lsothou}

A mothod of varying; tho prossurn whoh at the samg tiano

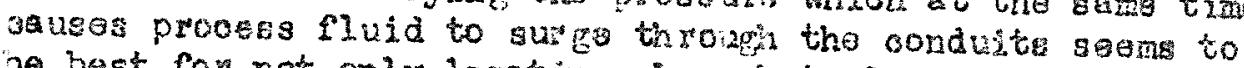
be best for not only losetine plug sur also possisly aliminative then by fluening then out of the lino.

Steps in this prooks whith leserence to the ajoutt ilagiem may be liated as follows:

1. With the metaris. pressure in tho rack at the norme

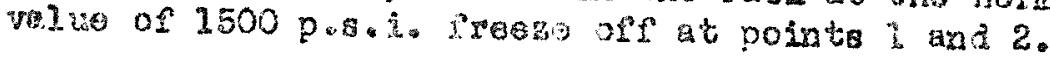

2. Raise tho naterial prossura in tho scalo tank to $1.00 \mathrm{p} . \mathrm{s} .1$.

3. Freaze off at peinto 3 and 4

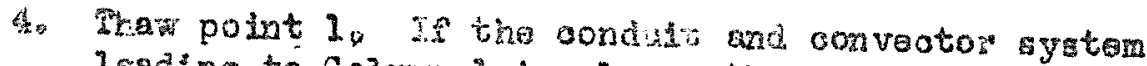
leading to Colum I in olgar, the gaupe rosding or

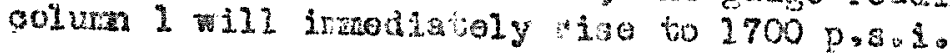

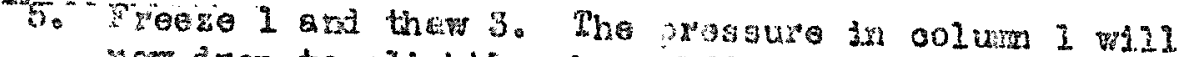
now drop to slightig tibovs 1500 posol. ond material w12. flow or sure from tha acorvetor 200 and ooluim into the reat of tha grroust.

6. Thaw 2, wepeathe at the ool nm 25 end of the circut the procoss dosurthod abovs.

7. Froso 2 and thare is

B. Fineily chaok for freadom of piugs aross the wholo botton of the circuit by thang at whish over ond is fros observing change in gaugo pressuro.

The above decoribad mothod hat seratil adventagos: not on $2 y$ doos it servo to locete a plug, but the pros iuro ohange oavea a surge of flutd wioh mey possibly wesp or prugh a plug out of a conduit or convector loop. Fuithermos" it mablas the operator to cheok both the oondults and conveutor loops syatem and sha botton of the oircuit in minimian number of operations.

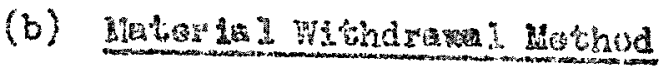

In cese of ther of the ganges used In the abovo discusad toste falla to zospond to the juo:enso in pressure or does not shop az repid a cienge in pressure as the gauge on the sow to the and if tha plue hes no: beon plushed from the

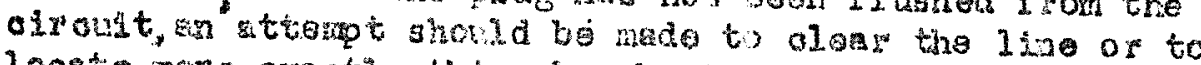
looat ane oxaty this plu by the following proosdure: 

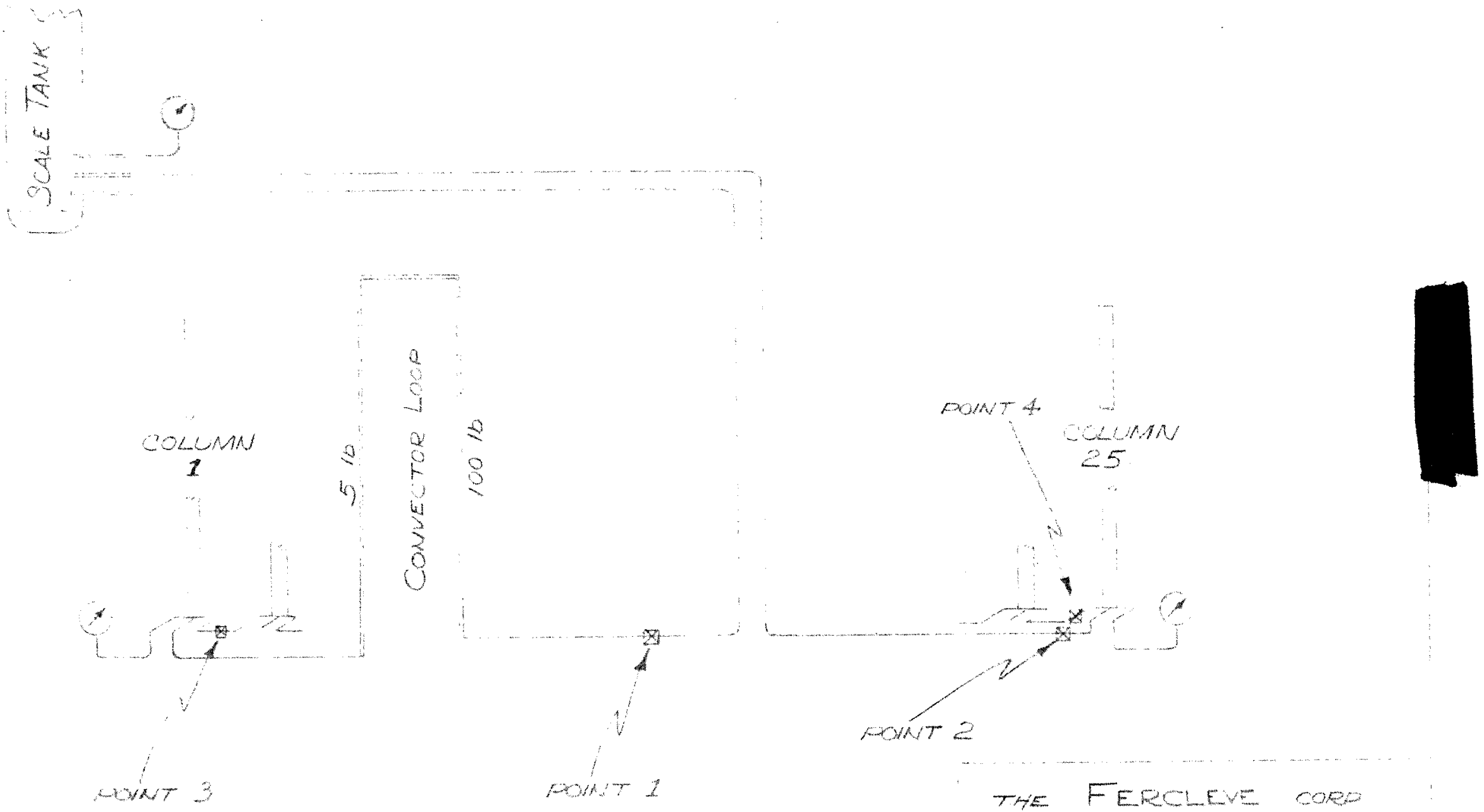

THE FEWGLE COP

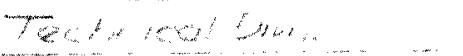

FHESURE WALIATOA NETHOO Frose the

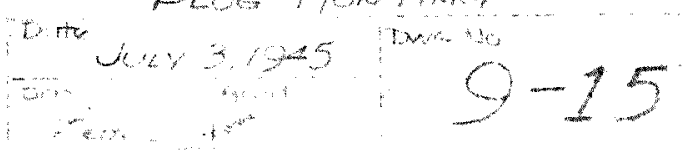




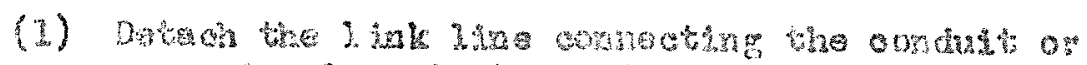

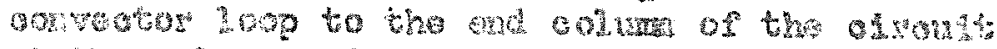

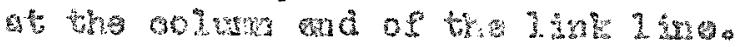

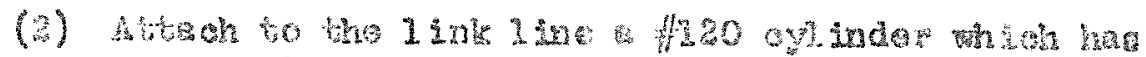

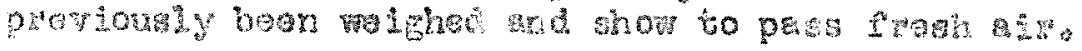

(3) Fand the ank Ine and tot of the oyindes mot

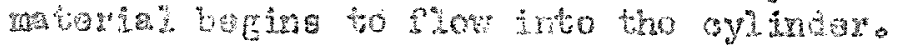

(4) An soon as the tomperature of the oylsmder hat

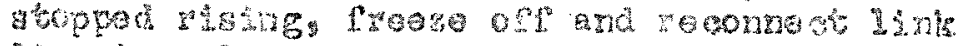
atre to colntas.

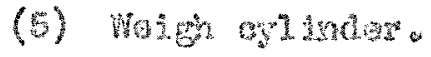

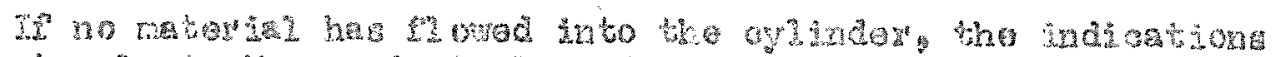

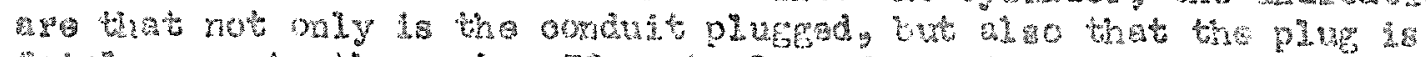

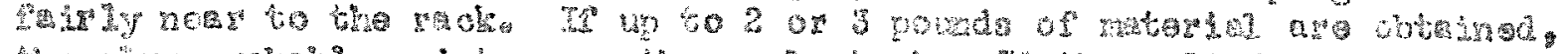

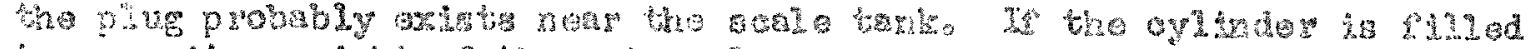

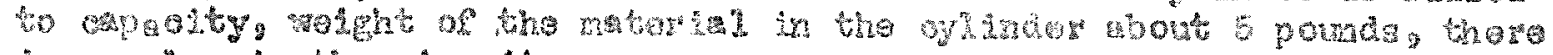

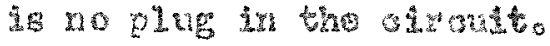

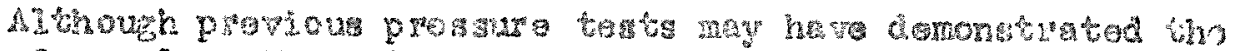

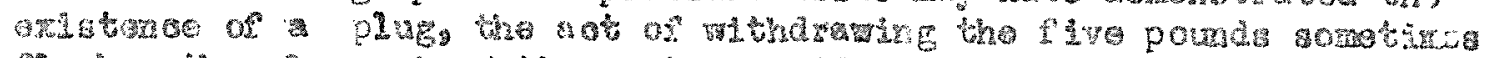

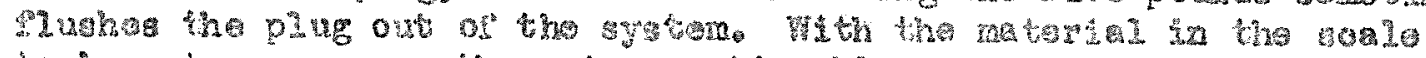

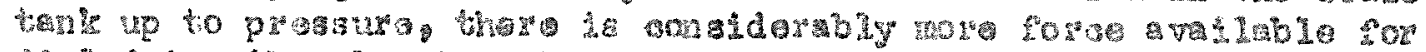

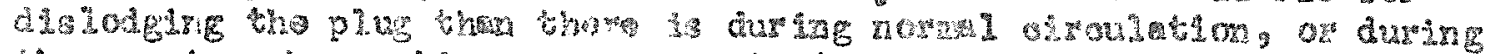

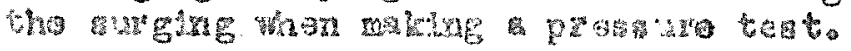

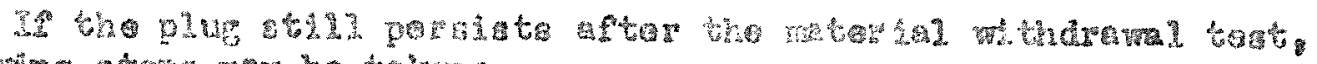
the roliew

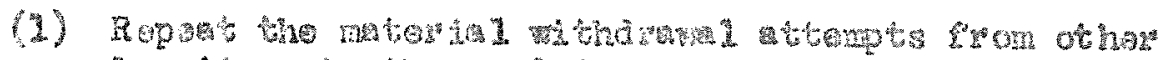

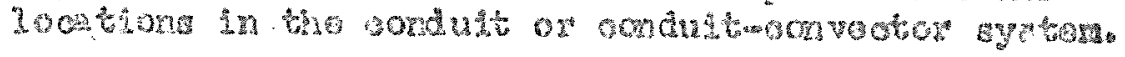

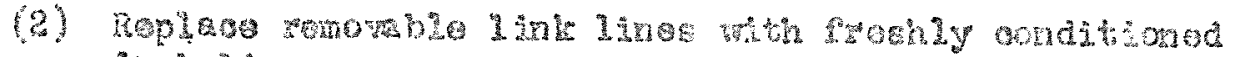

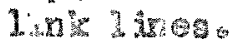

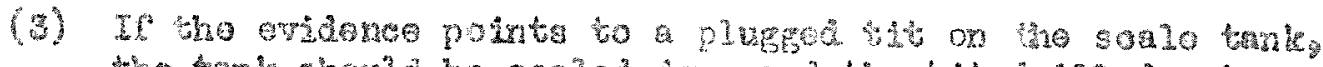
the tank shond bo ooolad cown whe the the dull od out by ingentangrios

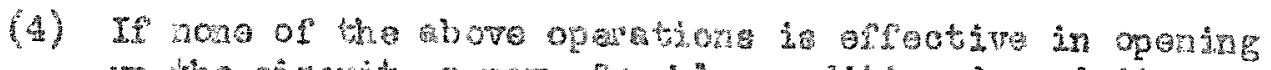

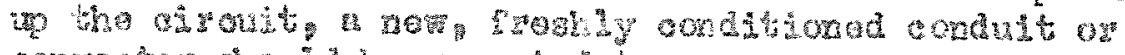

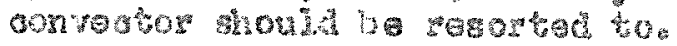

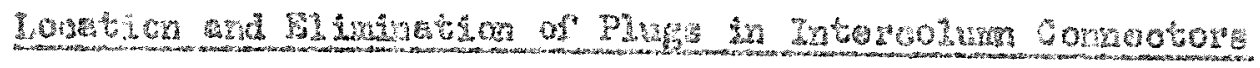

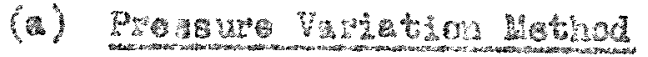

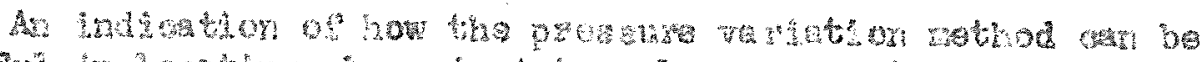

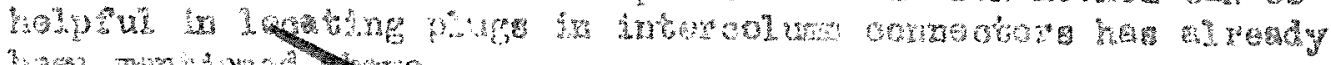

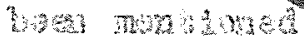




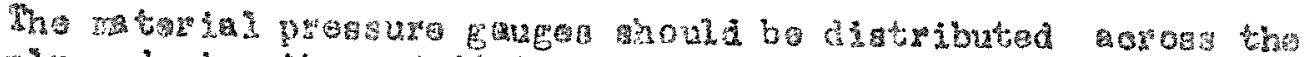

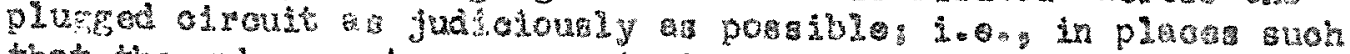

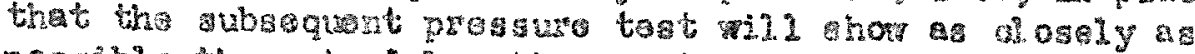
posaible the actur. I losetion of the plug. Prosure guges on

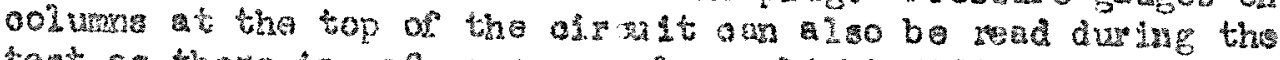

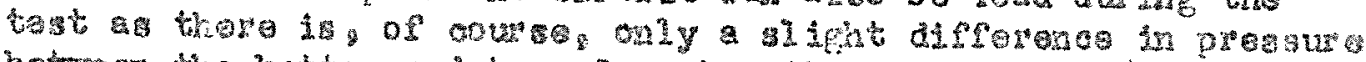

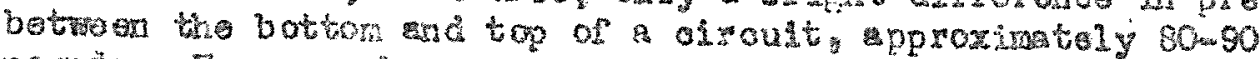

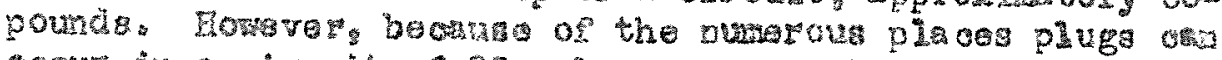

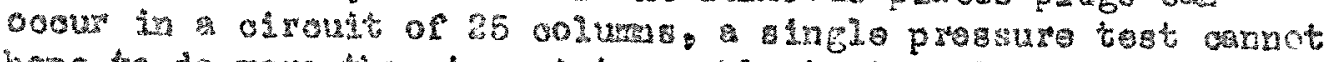
hope to do none thers to point roughly to the plug locetion.

Staps in the pperation of earying out the prosure tost can bo listed as follows:

(1) Attroh gauges to cal acted oolumas as many as tims axd avalubiatty pormit.

(2) Proese an both ande of the alrout.

(3) Lower or gatse the matorlal prossuro in the sole

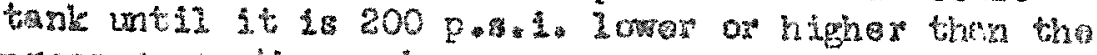
prossure on the raok.

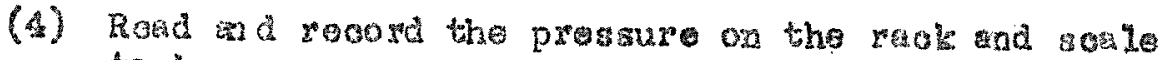
tank geuges:

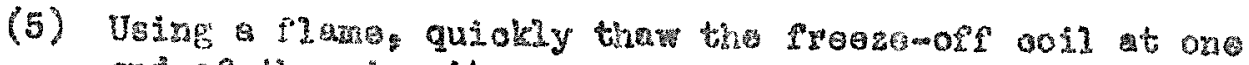
ond of the cryouts

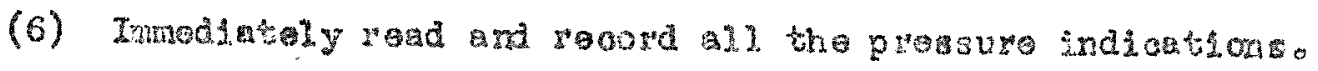

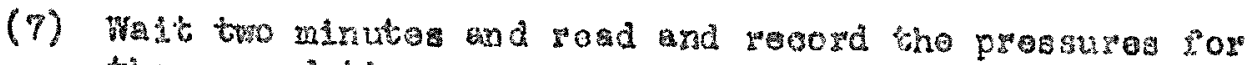
the gecond time.

(8) Thaw the freazonofs coth at the other ond of the elsout and rapent the preasure meacrarento

The next stog as to intorpret the dete which should be dose irmadataly befors aling any furthor tests. Ho detallot disootions can be given on the data interprotation, which depanda

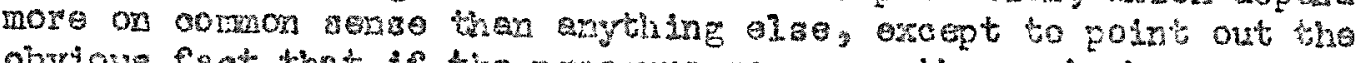
obvious faot that if the patsise gang on the rack ohows a prosau oh ge mithin a miruto, let us asy aqual to that shcm by the presgure gauge in the soale tank the circuit is open betwes the two gauges if the pressus gave charros slowly on the saok after thawing the oud ooll, the indiontion axe that a portial plug on restriotion exiats in tha line betrect the rack frace and soale tank gaugo. 
This firet presure vatation tegt nil probably losate the plug within 6 to 20 colume by onenging the position of the geuges, nagrowing the distance botrees thom, the 100 ets of the plug can be nore aodurately detorminod. Howevos. is takes quito a bit of tiras to onange gages: fur hingmore, ea ob ohange requirer tho opening of the oiroult wh resulting danger of introduoing moistura or of holang matoral break. Another mothod of detominting the looktion of the plug is to

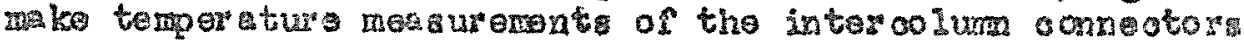
a described below. If tharmorater walla aro already attuched

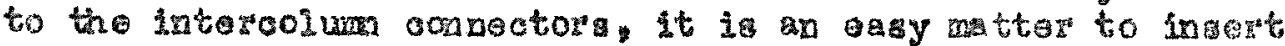
thermonoters and wo ke the nocassery temperature masurenonts.

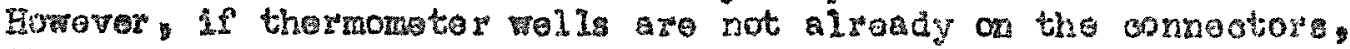

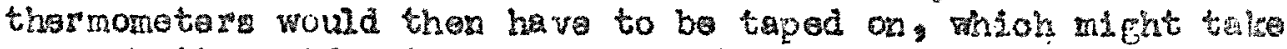
as much tine, if not more, thaz making one o: two chenpes of the pressure gruge locations. The rati foreman of porion

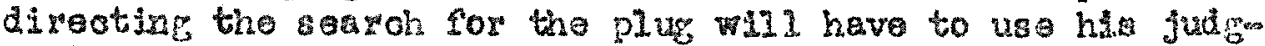
nant in deoiding which thod will ancio the plus to be discovered in the shortest ostinated tine.

The temporature woth od will probably bo quioker $2 f$ the loogtion of tho plug is not knom within 3 or 4.00 ungers.

\section{(b) Eomorgture loagurem at igathod}

This mothod is based on the fact that a plufiged inter oolum connoctor will not allow mtar in to plow through it and as consoguenoe cools off to tsuersture near to that of the duot. In the asse of a oloer interoolum aonector there Fll be onough baok and forth surging of the prooess fluid to rainte in the termparature of the inter oolum connector. to $130 \mathrm{~m} 170^{\circ} \mathrm{C}$. even in the absenos of diseot oi roulation. (The tomperature of the fluid ooming out of the colurms is in tine neighborhood of 220-2300 C.) The temperatures of the intercolum oonneotors of a rhole olroult oan easly be read and reoorded in 10 to 20 minutos, onoe the thermonstert hoves bon instriled and allowed to oom to thormal oquilibrium. Thus the lodating of the plug is done quiekly and easily by the temperature mothod.

The tsonntgue 28 a follows:

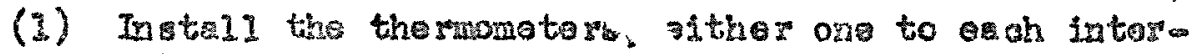
colurn connector of the wh le olroust, or $8-12$

thernomoters oovering the greauned pluged rogiton.

(2) Close the duot doors.

(3) Tait $10-35$ minutes. 
(4) With ons paraon reading and a sacond porwon reoording. read and rooord the temparstures of 1 the ingtollod thermometers.

(5) Study and interprot the data.

As it is in the osse of the pressure variation mothod the detection of the plug $100 \mathrm{tion}$ by the temperature mothod requires oonsiderable personal judgrent and oomor senso. As an orampio of the out of tomperetures observes and the? interpretation of the results, the following obser vations can bo given:

\section{Interoolum Connotor}

Taro Botwon Cols. Hurpoired

$$
\begin{array}{r}
1-2 \\
2-3 \\
3-4 \\
4-5 \\
5-6 \\
6-7 \\
7-8 \\
8-9 \\
9-10 \\
10=11 \\
11=12 \\
12-13
\end{array}
$$

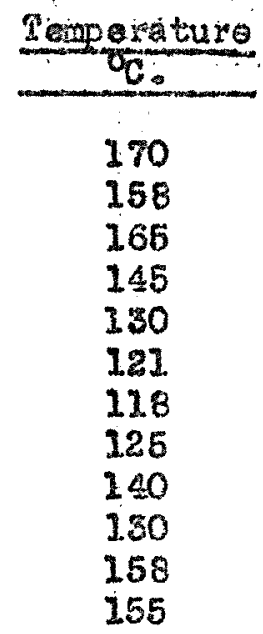

The tomperatire measurements ohow a definito although flat minimu betwoen Colums 7 and 8 . Tho piug wy be in this intercolura connootor. However, bafore ocnoludiag thet this is tho case, the duot aurrounding Coluras 7 and 8 should bo inepooted carefully to mke aure that the observod lower temperaturea are not the revult of oold spots cold air drafts, or dxippin: water.

At this point it should bo romerked thet the "epiti" test for old interoolum ocnnoctors often onables one to looate quisiry the oold spot in the oiscuit, this is partioularly true if pitohing is ooourring in the oisoust, inasmuoh $s$ fn this case thero 18 a large differenoo is tomperature betwoon: a clear and a plugged intercolum comneotor"s "ipwover, the "apit" test asnnot show the fine differer ces in tereserature required to looate a plus by the temperature measurement mothod described aboves 
Tenperatures indioated by the thermomaters in the Iloffman Flow Indiostor should also bo oberver, beceune fron these terroar atur an the change of the tomperature of the two ends of the Indlactor with time one and tell Whather the Indisator itsolf is plurged or not, if the $\Delta$ T' ohange La magnitude and also in algn with time tha

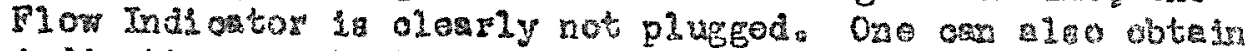
indieations as to the looation of a plug by notictng the period of a eurge; a short period indioates a location or the plue aloser to the Flow Indiator than does a long portods

\section{(a) Uae of By wase}

Unforturitely neither the pressure variation nethod noy

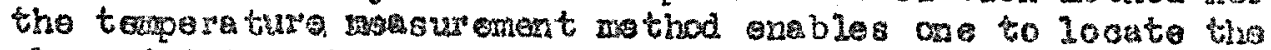
pluceed intarcolum oonnector alway bayond doubt: for cinal proof the conueator should bo byopased by short 1 ink Iine Funnine frow the midal tis of the colum on cos aide of the comnotor to the midal e tit of the oolum on the other sides. If circulation is started by virtue of terial being ablo to 12 cm through the by-pas the by-peased intercolum conooctor is probably plucged. If oirculation doos not atart, the plug is probabiy in another interoolume corneotor. othar possibilitsos po plugs in oither of the two middio tits or in

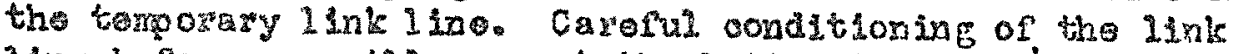
1.ne bafore us will provent the iattor diffioulty from ocourstag. If a gauge hed boen previouely inateiled on oither of the two niddie tite and had been yesponding properly, that

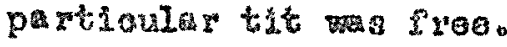

The use of temporay by passes in revommended booureo sometines it saves the opertat scom removing w intercolum conneotor thich is not piugged, it is diffioult and dengeroug job ahanging a interoolurn connector and should not bo attempted vileas absolutely wo cossery. Howevar, the se a oortain preoutiona in the use of terposary by-paras which should bo mpastzed, namely:

(1) A temporay by-pass 12 Iaft on the raok should bo wired to oopper freerewoff 1 ino so thet it oan be frozen off whan the rest of the botton olxcult is frogen off: otherwiso intercolum oisulation Wll. oocuis when the top oirsult becomes thamed.

(2) Befor ohanging the interoolum comeotor tho tagnorasy by pass should bo frozen off to see if oifculation is stoppod. If of $r$ ulation opatisuos, the intercolum onmeotor is not plugged and need not bo changed. Sometimea pluge thought to be in interoolum conneotors oithor nover xally axistod or distapoen due to pltching or for other unimowa rass ons. 
(3) Aster normal operation ha bes atabliched on raok, the rock ahould be "clemed up" by tho renovis of all temporary by-pasos and the ropleceo mant of the pluggad intorcolum comestors nith clon coes.

In case thero are seroral bympassos on a cincuit in Which oirculation has not boen started and if it is dosired to remove some of thone by-passea, tiest of oiroulation through the bympassed in tor colurea oon no ctor oan bo made by

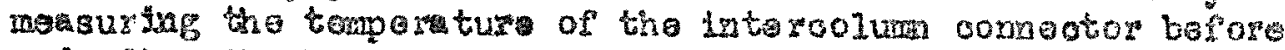
and ifter the by-pass is frozer off. If tho temperatura

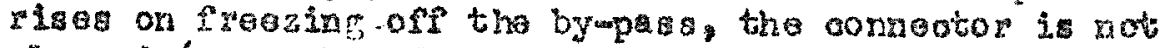
pluggod (oaro should bo tako to allow tomporature oruil) Ibriva to be astablished in the duat barore nsking the measurenento)

\section{(d) Paytial P1tohing Method}

A though nornaliy pltoning 1 to be avolded the al coste because of the diaturbanos it ouses to good operating conditions, nevertheless, a limitad amount of it may bo

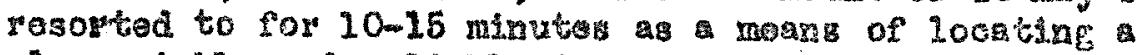
plug quiokiy and rellably in a pathoula iy bafeling pluggod

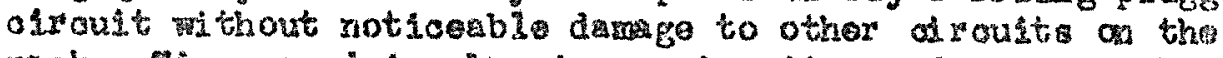
raoko ismo sared in olearlag alrcuit may far outweigh disadvantsges ooour wing from a fow minutes of pltohing. Tookntque of cerrymg out the pltching teat for olue may bo aumarized as coll ors:

(1) Freaze of the end of the oircult nesregt to the suepocted losation of the plug. The matorial pressure in the of roult should be betwen $2400-1500 \mathrm{p} .8 .1$.

(2) Botwoen the bove two points witindraw a No. 31 oapsule of torial.

(3) Obsorve the extent of the pltohiag in the eirouit. Tho plucged intarcolum onneotor will be batrasn the end pitching oolum and the sirst oolum whose raterial la up to pressure。

(4) Inmediately thar the frowon ond coil 00 that the pitching oan be topped without delay.

Not only is tho pitoning mothod axtremsiy reliable, but the pitching also sometimes helps to sweep out the plug bocaus of the oons idoreblo differenoe of prosure existing during pitching oross the plug. Furbhornore, the pitohing method ang unoorey the existemce of two plugs mon only ore is supposted. 
If the pitchung region is bounded by zogion of non-ptohing coluan, at least two plugs would be indiceted.

If a conveotor loop existe In the niddie of a plugged oiroult, it is a good ldos to withdras mater ial from both ond of the top of the $100 \mathrm{p}$ into No. 120 oylinder. If each oylinder is filled, the ontire cir sutt mist be froo If a plug existo, the olloilt will pitoh from the convector loop up to the location of tho pluge.

\section{(0) Material Surge Eethod}

Sonatimes a plug can be flushed out by oausing the Interial to susge baok and forth in the oirout. This is dare aasily by the following sezies of oparations:

(1) Eroese off the far sad of the oiroult and busld up the prossure to $1700 \mathrm{p} . \mathrm{s}$. 1 .

(2) Frove off the near ond.

(3) Lower the prosaure in tho a lo tank to $1400 \mathrm{p} .8 .20$

(4) Inser the far ond of the oixouit.

(5) II this troatmant falla to dialodgo the plug. repat reversing the direction of the surge.

It hes sonetimes bera suggested that rapid surges in oixcuits may ots u sodiment, thus cousing pluge to form where plurs gevey had proviously existed. While this may bo trus, its also possiblo thet sediment zay be whishod out of a oircult by raplaly fowing material though it as in the filling prooegs of the Raok 9 method of operation.

Pluge in Iitg

(a) Indjoations of plucerod Pits

A plugered tit is suggeatod by:

(1) Failure of tho meterial to olsoulate through a seshy sonditioned inter colune oonnootor.

(2) Ilo fuming of matorial out of a "arached"

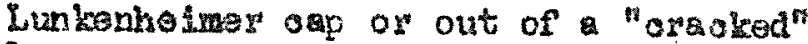
Lumkenheinar oonnestion to a frozem interw oolura conaeotor. 
(b) Methode of Deteoting and EI ininating

Attempt to withdram Intersial out of the suspeotad tit into prevlously woighed smil size eapsulo, No, 2 and No. 4. If an oumo of moterial is not obtained, the tit is plugged.

If the tit connot be olsared by the whiramel of materias. it must bo drillad out by intenanoe. In the meantimo anotheis tit on the oolurn can be uad.

In concluding this seatton on the looation and elimingtion of pluga, it should be soomphasigd that a of cuit should nevar be oponod to the atmoephere miess absolutoly nocossary. that all rew Gquiprest added to a oisouit such an ink linos

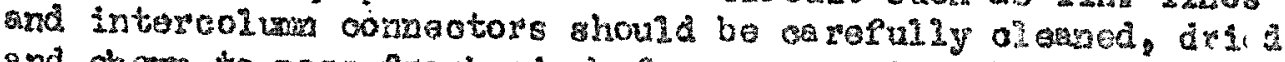
and show to pass fresh aje before use, and that not only is

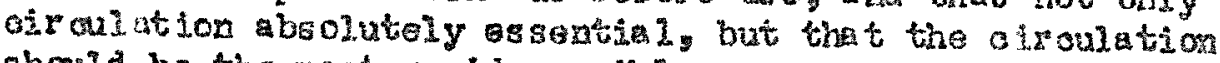
should be the most rapid posible.

\section{Pyooodure do the Eveat of a Planned Shut doren}

n. Objeotive

The objoctive sought in the ovent of a shutdowa is to Guaranteo that no damge shall roault to equipment oithor during the shrtion or subsequent to it. Furthormore, it is denized to guarantes that atertamepronodure be made as inple as poseible by reason of the fact that propor steps have beces taken at the time of the shut-doen.

In any case of stoppage of operation it is ilways necessary to isolate the transfer room from the rakt. It is furthaz nooessary to igoleto all oolumn Prom ach other. If this prectioo is followed startm proosdure boeonen very airmio and the possibility of damping colluas dine to excessive hycrostatio pres sures of tho procesis fluid vanishos.

\section{b. Stges in Shutting Dorn Rede}

(1) Preace off freezemoff ooils bebrean teringm boxes at the sack and oolures. This will prohibit any transfer of material from the raok to the tranefor room ox vico vorsa.

If an extremo emergonoy ostate the condutt I ines on be flooded but this should be done only on the apocifio authorsty of the Technioa siperintendent. 
(2) All colums should be isolated from oach other by freezing ell intereolusan ocnneotora.

This may bo dome on eome racka manually by opening the valves on the stamdby water 1 ine on on other reoks by throwing the proper solenoid ewitches to flood the lines leading to the interoolurn comeotors. It mus be noted trat if only one os revit so betng frozen off the valves loading baok from the cirouit boing frozen off should be alosed before opening the standby veter 2 ino val ves. Othermise, the whor will go back through the autonetio valvea and flood all the lines in the rak. Thig, of course, nead not be considered when shutting the whole rack dom.

(3) Onoe the isolation of all oolumns from oach other and the transfer room has bean aocomplished, it is then permisiblo to olose the main $6^{\text {n }}$ steam valve supplying toam to the raok.

(4) C1zoulating pumps may be turned off after stam prossure has dropped to $251 \mathrm{bs}$.

(5) The stean on the dopvetors and oonduits should not be turned off unless the raok is to be down for a oonsiderable length of time or unless asked for by the Stoam Department. In this osse, the steam should be turned off after the reat of the rack has ooolod down so that material will not bo draw into these lines by cooling thom first. It is oonsidered better to have the matoriel dram out of them by oooling the co? ume firet so there mill be no probability of breaking tham when starting up.

(6) It is extremely important that the responsiblo person operating the raok at the time of the shutdown reoord in detail the prodedures omployed in shutting dow. It is sspooially important that any observations regarding flow of material in or out of the raok as reoorded by the transfor room scales be noted.

7. Prooedure for Starting up Rack Aftor a Shut-doma

\section{- Chook List Before Starting Vo}

Whilo a rack is stut dow for eithe ma intenence or stean diffioulties the rack orew has many things to oheok and to repair before starting up the raok again. Some of these are listed below: 
(1) Remove from each olroult all ooluras showing meterial. losks at the top of the raok Exceptions to this aro colums haviaf, leaks at Lunkenhajne comoctiona whith oan, of couzse, bo dienged to battor pittings.

(2) Inspect 11 sateroolum oonneators to mave sure that the riokel link 1inse are 11-soldered to tho copper

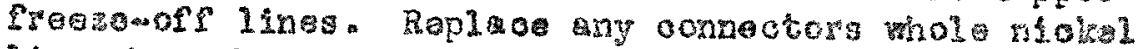
lines havo broken awe from the coppos. It in apparatiy satisfartory to wiro these tubes together if nocossary but the wing mugt be done in guoh way to was as long a contaot as posaible between the nicisel and the copper.

(3) Chook oonduito to mako suso that stoan has been kep' on them dur ing the shut-dow period. If they have beco allowed to 0001 and must be thened out botore starting up the reok consult with the Tochnical Superintandent on duty bofore atiomptior to thaw out the lines.

(4) Cheok all civouitr for oomplotenoss of connoctions and proper froezomoff 0013. 1180 chook with the diagram on the rack chart.

(5) If tho conveotor loops have been llowed to cool during the shut-down pariod, make sure that the intocoolure convectors are hot alcng the botton and that the link Iines are hot before attempting to thaw out the oonvootor loops.

(6) Install naw gauges wherever nooded and when gaugec aro available.

(7) Before attompting to start up a rack oheok 11 the valves on the tops and botton of the ooluma, maling sure that the stean and weter velves are all open, exospt on the bymessed colums, only the reter valves are opened, oheok the i $E^{*}$ vent Talves in the water system, cheot all duots conduits and oonvoctors for proper tomperature; in other words, cheak the ontire rack to ma sure it is ready for oporation. Do not assume that it has stood all right and without change during the shutwow poriod.

(8) The risal step in starting up the sack again is to who sure exactly how the rack was shutadowa If posaible the operator should oontact the person who was in oharge et the time of the shut-down. Pertinent in pormation should bo in the log book of the reck at the tine of the shut-down. 


\section{b. Prooedure for Starting up}

The firct stop to bo taken in aotue $11 \mathrm{y}$ starting up is to make cortain that the osroulating mater is Flowing and that the ciroulating pures are functioning proparly and showing the propor discherge pressure (at laas 30 lbs.) The duct system should then be olosed and heatod.

Stom ay be $\nabla$ alved into tho system through the byopass a round the matn val ve whth the objoctive of hoating the airoulatiag water up to $150^{\circ}$. Prosare of fluid within the rack should be hoted by means of pressure geuges at the tops of the columns and under no oircunatances should the pressure bo allowed to oxoogd $2500 \mathrm{lbs}$.

If propes stept wero taken when freoring the raok dow there ghould be no diffioulty in having exoess pressure in the oolumns. In no lastge pressures are observed it is then possible to opon the main val vo madually. This must bo dono fairly slowly, i.e. the pressure should bo incressed pion 50 to 100 pounds over the course of about 20 minutes. At all times there should bo operators on the top of the raok oberving fluid and steam pressura and there should also be an operator the transfor room noting any changes in the transfere room. Operstors noed not be alarmed if fluid pressure as zecorded by at least two gaures at the top of the colums $x i s e s$ to 18001 b8. Ilowerer, if the rate of inorease is rapid and the pressure shows signs of inoveasing boyond this point, the stakn flow into the raok should be cut dow until the pressure situation le under control. In this casa, contaot my bo made to the soalo tark by unfrearint tho bottom intos. column oonnectors and the tits on the soalo tank. This should be cone very carerully with close watoh being kept on the weighta and prossures in the transfor room.

Unlosa gomothing is radioally wrong ouoh as plugged lines, plugged gauges or leaking ooluma or oonduit linos, it should bo posaible to bujld the steam prosiuse up to operatine value of 1000 lbs and the guages at the storage ohamber and it the top of tho oolums should o one to reme in the same within the limits of the probable erras of the garisea. This may be ione in approximaly 20 minutes aftar determining that the rack is in satisfactory operating condition witi no excessive pressures being notod. If all has been done properly, the olroult should oiroulate vory goon after tho system has been opened up.

\section{Speoial Raok Proogduras.}

The original method of operation which consistod of allowing the circuit to ciroulate at all times across the bottom of the cirouit except when the colurm was taken from the top of the colurm by somo suitable "milking" mothod has given way in sovoral racks to a modifiotion which is a prost deal oasior and gives essentially us
satisfactory rosults. 
Othes modicications a a beinf tried at various timas in an attempt to inerase anount of product boing taken off and to meke the prooss oasior in its manipulation.

\section{a. Top Cirouiation of "pineapolo" lethod}

This procodure was first tried on Rack lo, 9 and consisto of a syatera designed to ofrculate nozmally theogh the botton of the rack for part of the time and then, inatead of taking off the product desired on the top of the oolume, to airoulate it into anothes regervoid at the top of the raok. The pureiple of this it that if ong states withir nomel matorial in the produot containor and sirculates end miges It Fith ansiched matorial, it will con reach a higher velue intermedinto betweon the matorial in the oolums ond ita starting value. If thon, the colums continue oporation. the conoentration of the product on the top of the col tarn inorerses further. This ie followed by nother period of ciroulation aoross tho top.

This intermittent oiroulation between the botton wha the top is ocntinued untll the resaroir reachos the oolasentration desired. It is then ropiaced by anothar contasner and the prooess is reperted. The advantages of the system aro in the caot that individual ralleinga or product withdrand are not nocassary. Tho oylindor is ohanged wheneror nocessary saring a reat dosl of tino in raok operation. The two mothods acm to give coroyarable Iesults with the top ciroul ati on method having possibly a sifht advantegen Dotails of tho proadure aro given in the soction on Product withdrapal sethodis.

\section{b. Intermittent Ciroulation Mothod}

Anothar vartation on the standard procedure of xale opdretion is based on a possibility that the ciroulation prcooss disturbs the aotion of the colum. It is a nodification of the normat mothod in that instead of allowing the oiroult to oinculste at all times exoept when produot is boing whindarn, the of roujt is frozen off approximately half the tine.

The method congtsts of morely freezing off the rack aftar cifculation has been established and letting the colums operato. Intermittently, then, tho cirouit is allowed to oiroulate and bring fresh material into the oolumn but then is frozen off again. This ha been txied but no evaluation of the method has yot beon obtained. There i eviden on that when a raok is startod up after a shut-down it is woll to start the airculation and then frease of the eircuit for several hours before attempting to whar tha product. 
9. General Bnorfonon Instruotlone

FOR DETAIIED EMEROENCY IMSTRUCTIONS SPE SECTION 0

Dos igr of Equipoent

In deaignigg ooluto tits and connecting lines, ono of the prinoipal consideration has beed to lintt the mow which could ocour in the event of a dofeotivo connotion or breakge of a 1ine. $A$ mingm size of orifies is required in ordex to permit proper sirculwiton in the various onveotive loops axd it is this faotor which preventa dourase in the sizo of the connecting linoa. As a result of exparionos to date gome ostinator oan bo made conoming the rato at whioh matorial an asoepe in the ovent of verious breaks ooour'sing on the reok.

One of the factore in the ecoape of the materiel is the tirenendous compressibility of the matorial at the conditions of operation. At 1500 povad prosurs the prooess fluld is compressed whout threo times as mon as a parfeot gas mouzd be undor those conditions. Fhiz mosa that the tendenof for the naterial to ssopo in a great deal more thm ovan the pressure would goen to indicato. For this reason, \& small broul soems to be quite large.

Rate of Esoope of Waterial

If a broak voours at tho top of the rtck with all interoolum conneotors frowen the logs ell1 not oreood \& Ibs. minute. If tho freezers aro open the rate of 108 sill not axceed 8 Lbs. a minute. These figures, of course, refar to unrestitoted flow through a colum tit ox through a $1 / 16^{\prime \prime}$ I.D. niokel line which has broken complotely in two. If the tit is partially cappea, flow wil be considorably 108 arra in most ossos w1ll not total wore than $1 / 2 \mathrm{Lb}$. per minute.

In the event of a bresk at the botbon of the raok the quantity lost will depend on the lo cation with respoct to inooming condut lines, and also upon the diametes of the conduit lines being employed. In the worst, case, namely a break of an open onduit line tit, the rate of loss 1111 bo in the noighbornood of 61 bs. poit minute. For a partialy caped open the loss is probably of the order of $1 / 2 \mathrm{lb}$. per minute.

\section{Goneral Prooedure}

In dotomining tha prooedure to be employed in the ovent of a material break much dapends on an eztimato of the rate at which the materiel is esoaping end its guality. During the initial period of etarine up it 18 most inportant to koep oguiprent in operetion. 
Therefore, when bratis oucur oporetore should atiempt to disturb other gysters at littio a posibio. It is posatble to shut tho gteam off tine raok but this does not usually eren need to be contempleted.

With oxparanco, operatore will gain the ability to eatinsto the Fate of loss which 1 a ocourring in a break and will rocognize

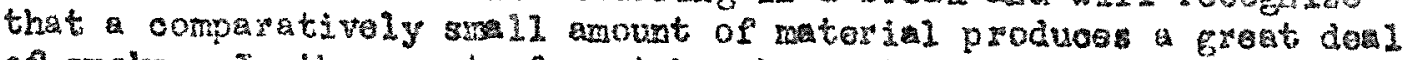
of smoke. In the ovent of mit breaks partioulary those due to incomplete oapping of the tits the procedure should be designod to isolate the colude or pott that is leakine frow tho reat of the system. This on be soomelishod by freazing the intoreolum connectors and oolls. Is the breale should happed to bo in the condutis, then, the atorage tanks should bo fucen of a a the brak saolated. It is possible to Rlood the oonduit but this proeodure is not considered advisablo in ary oxtent as it lo lmost certain to breaix some of the 1 ines in the condust which have netorel in them This sfeots the whole coxduits system. Agata. let it be ogld that this is to be done only on the express direotion of the Tecinicel Superintendento

It might bo added that personal safety is more important than the matorial lost. In any oae of an morgonoy, the oposator should not oxpose hims al induly but the safoty Depertman' has made adequate sacepuests for the bafety of the operetor. By following the prooedures sot up in this manus 1 and edequetely sefoguarding hinself there should be no posslblliby or hara coming to an operator.

10. Control Room and Control Dovioes

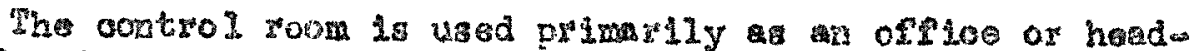
quarters for the rask orat. It is mall to lnow wat the verious devices ars fox oontrol purposes, and whet the limits of operation are in their cporetion. The following tablo lists the devioes that are oheched by tha Oposiations Departuset but does not inelude

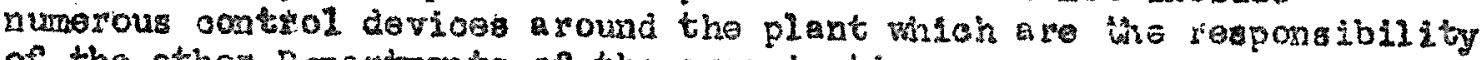
of the other Departmonts of the orgenieation:

\begin{tabular}{|c|c|c|}
\hline Costrol Dovioe & $\begin{array}{c}\text { Limits of Nongal } \\
\text { Operstion }\end{array}$ & $\begin{array}{l}\text { Wom to Notify } \\
\text { of Abnormality }\end{array}$ \\
\hline $\begin{array}{l}\text { Gaugea } \\
5 \text { pound stean } \\
125 \text { pound atean } \\
\text { dake -up water } \\
\text { Colum discharge temperatur } \\
1000 \text { poud stean } \\
\text { Ciro. weter suction } \\
\text { Ciro. water dischasgo }\end{array}$ & 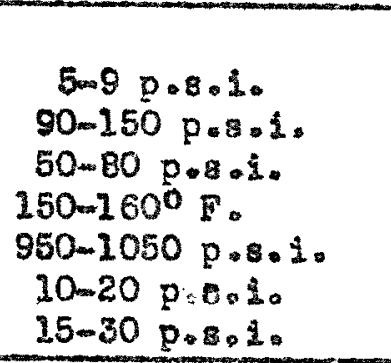 & $\begin{array}{l}\text { Stean Dopt. } \\
\text { Stoam Dept. } \\
\text { Stram Dopt. } \\
\text { Raok Roraman } \\
\text { Stoan Dept. } \\
\text { Steam Dopt. } \\
\text { Stoam Dopt. }\end{array}$ \\
\hline
\end{tabular}

Table continued on next page

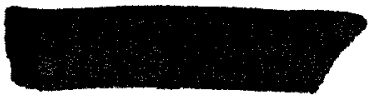




\begin{tabular}{|c|c|}
\hline $\begin{array}{l}\text { Limiss of Normal } \\
\text { Opertet on }\end{array}$ & $\begin{array}{l}\text { Whom to Notify } \\
\text { of Abnowated ty }\end{array}$ \\
\hline 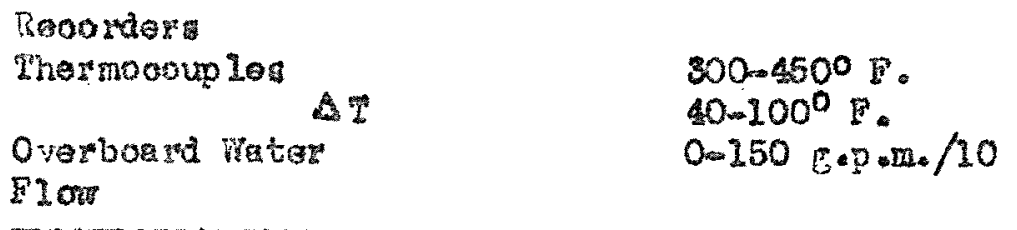 & $\begin{array}{l}\text { Raok Forentan } \\
\text { Rack Foremn }\end{array}$ \\
\hline 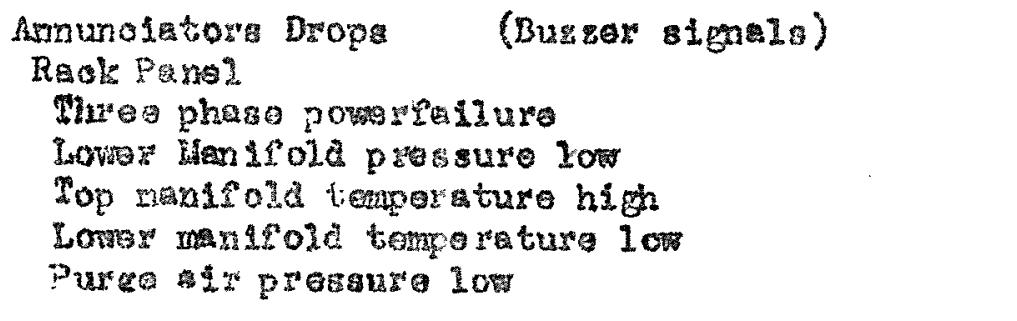 & 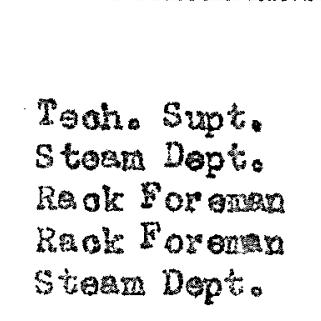 \\
\hline 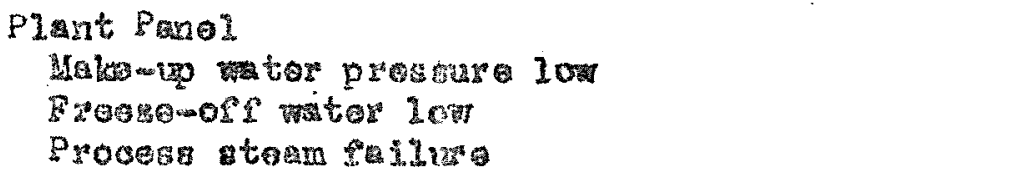 & $\begin{array}{l}\text { Steam Dept. } \\
\text { Stoam Dopt: } \\
\text { Stoan Dopt. }\end{array}$ \\
\hline
\end{tabular}

S00 Dwg. Ho, 9=10 


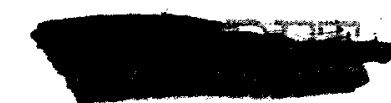

(1)

2
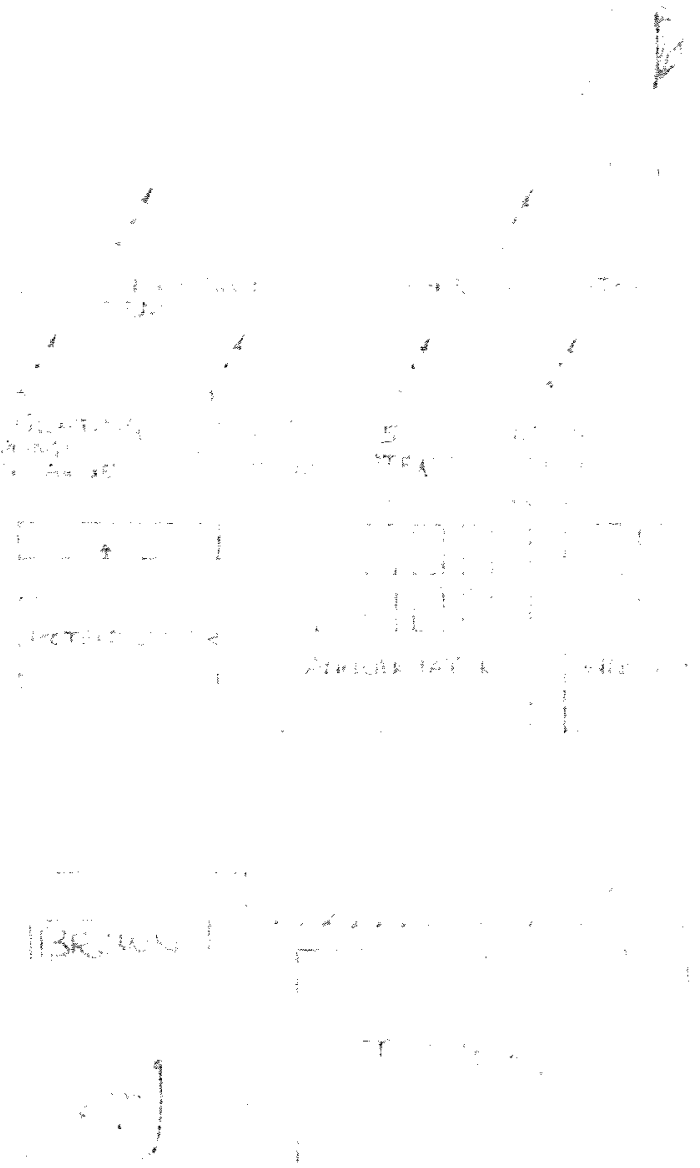

(2)

0

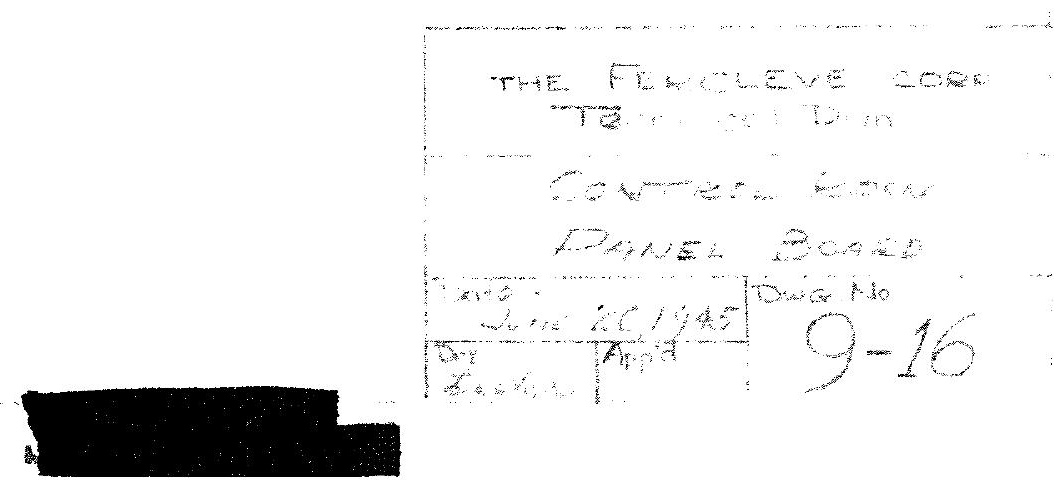




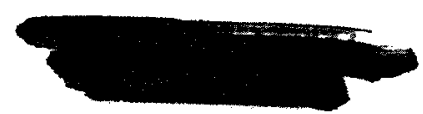

Bus

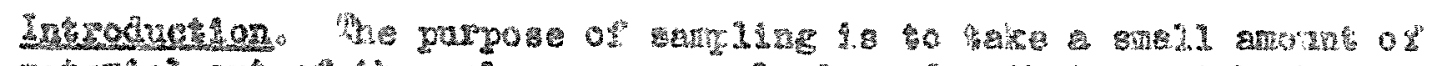

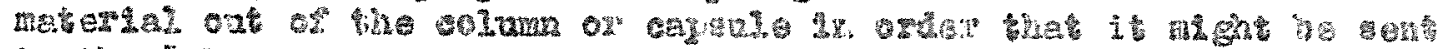

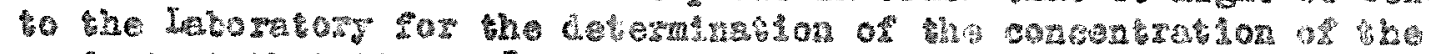

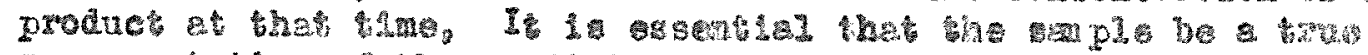

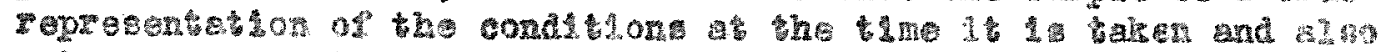

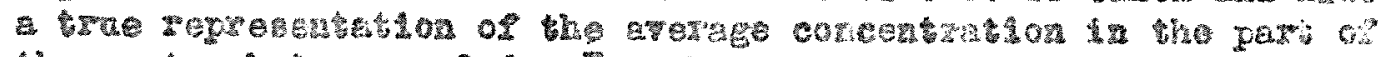

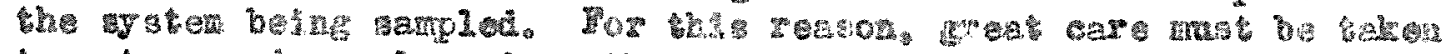

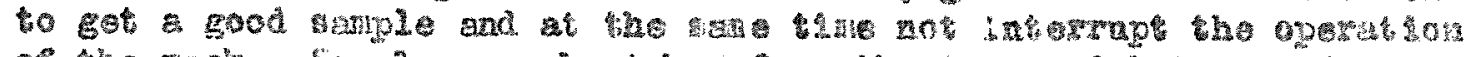

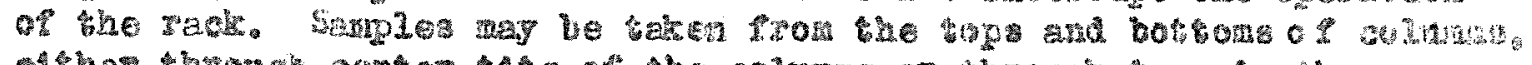

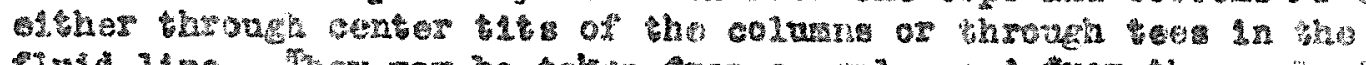

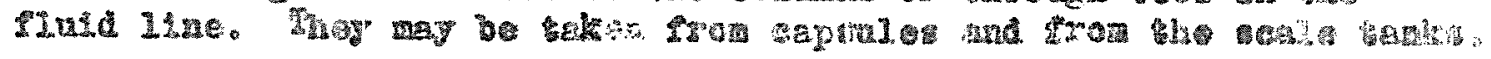

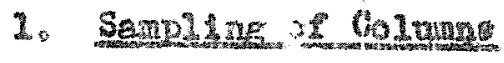

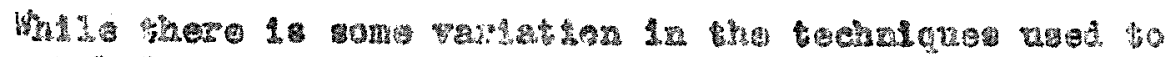

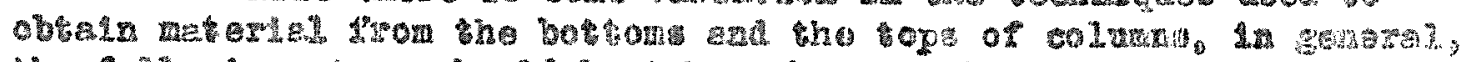

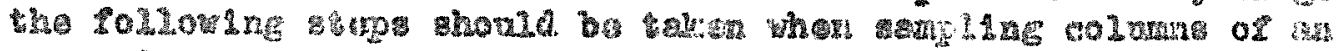
operateon satems

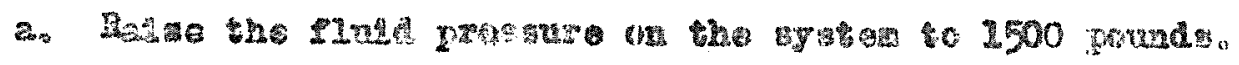

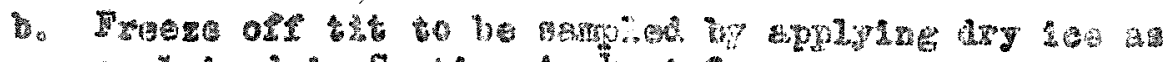

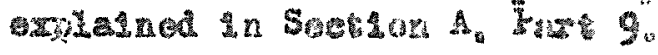

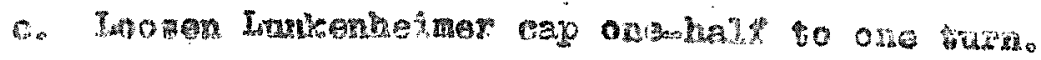

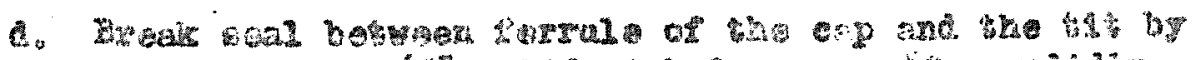

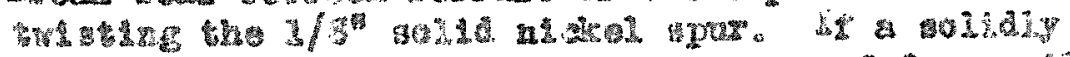

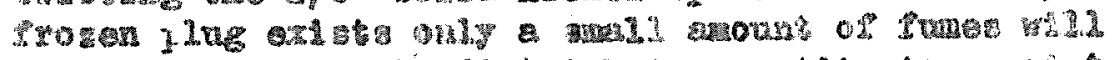

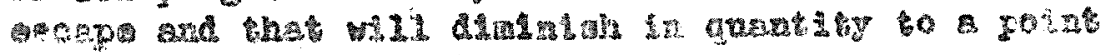

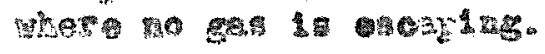

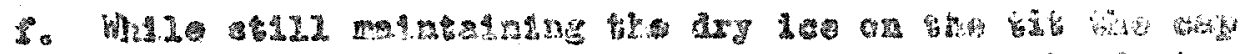

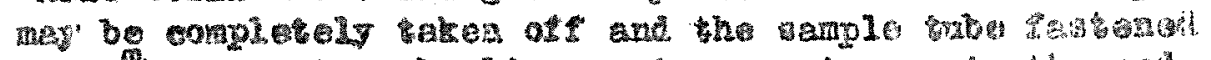

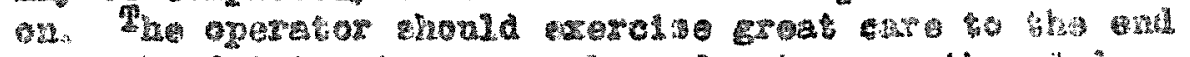

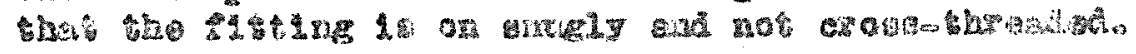

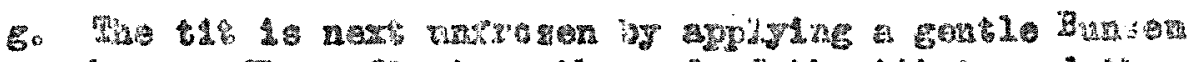

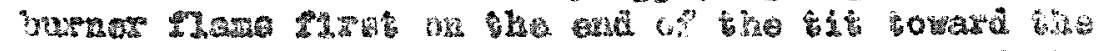

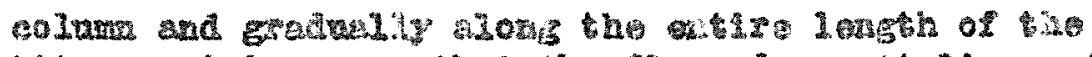

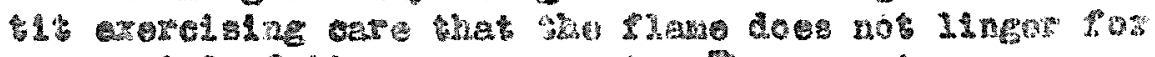

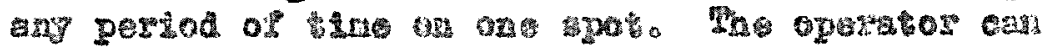

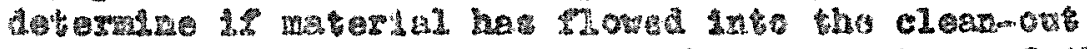

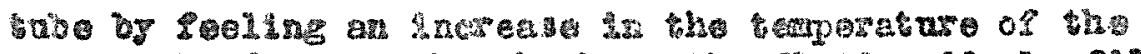

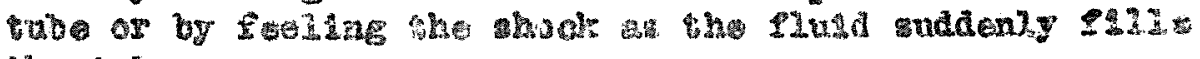
sis astho 


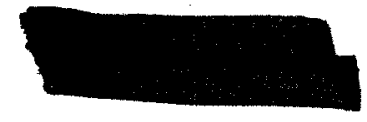

is. The the shondd agela bo 1rosan oft sa above and the

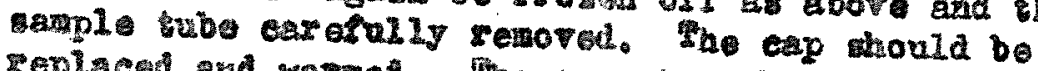
Eeplaced and warmot. The aphrabor should be ware that the the has warmed ap before hi leeves tho ricialty ia ortar that he me be certalt thet no leak doralops at tho conneotlon. The sangio trob hovid bo examined to

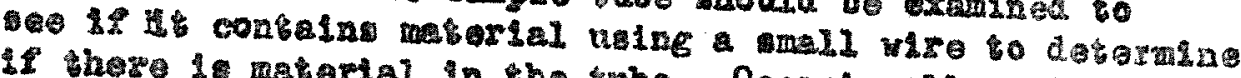
If there It matortal In tho tubo Decalonely. It is

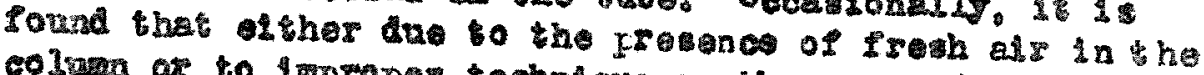
colvan or to laproper techndoue on the part of the opwrator

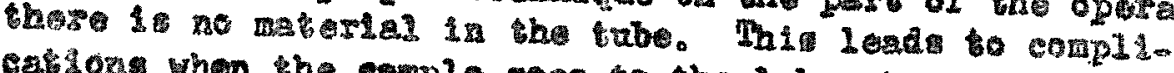
cabsons whon the emplo goos to the laboratory.

2. In all caser the camile wh the ramplo zecord eard

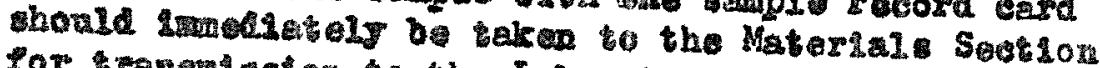
Lor Fanand Blon to tho Labortory.

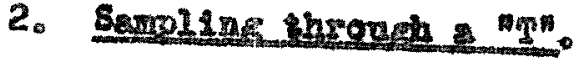

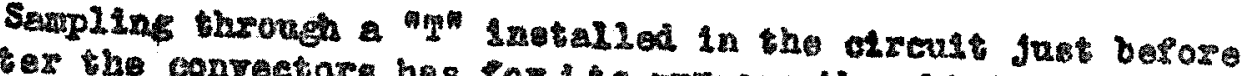

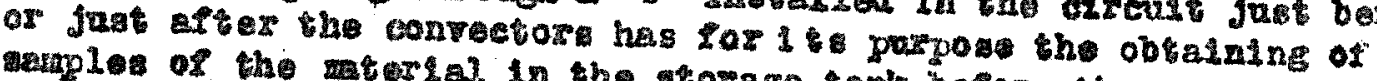

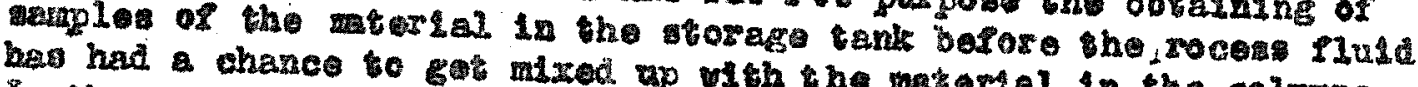
In these procadwres the tochngove is the matamal in the columes. colmans. The etapa are to flowa:

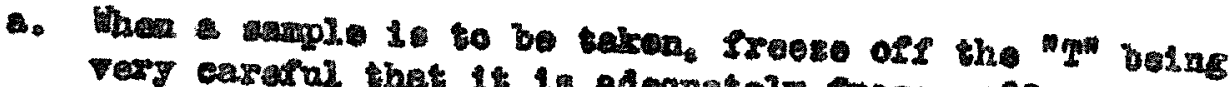
very caraful that 14 ic aloquately frosen ot?.

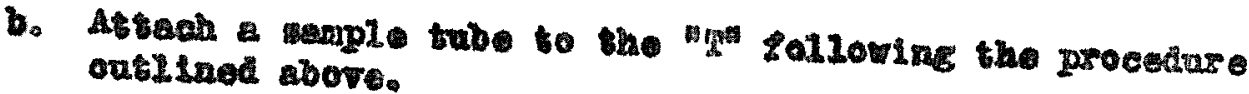

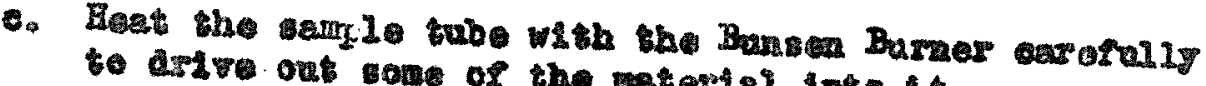
te drtve out com of the restal tato it.

d. Cool the anplo tub inth any 200.

- Careculy Ireare ofe the mpt.

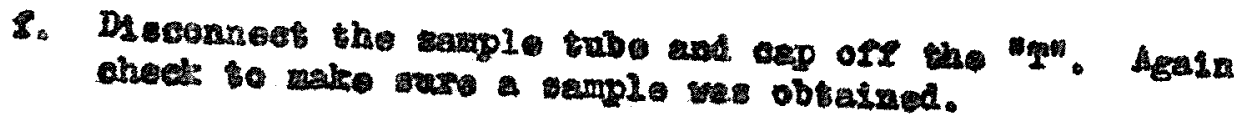

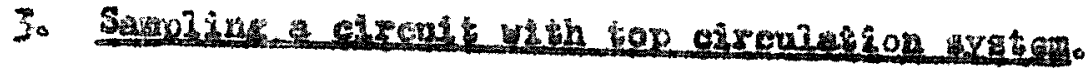

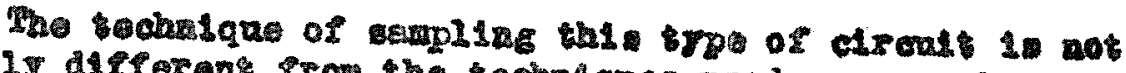

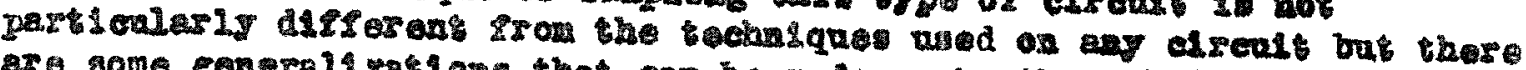

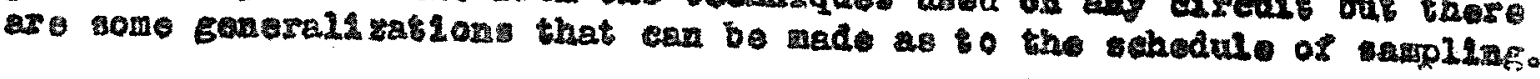

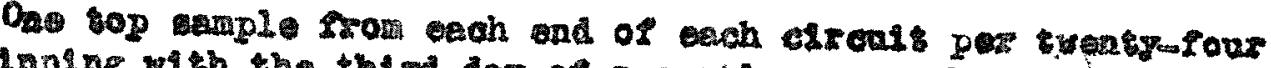

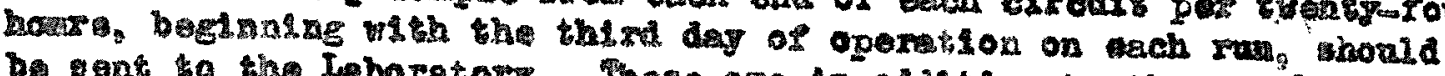

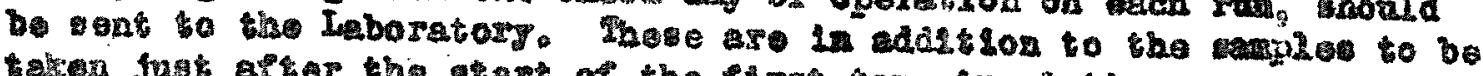

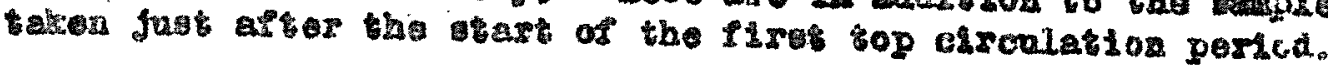




$$
x \rightarrow y_{x}
$$

The

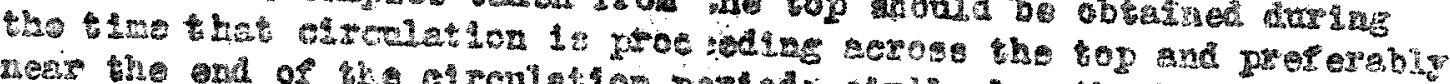

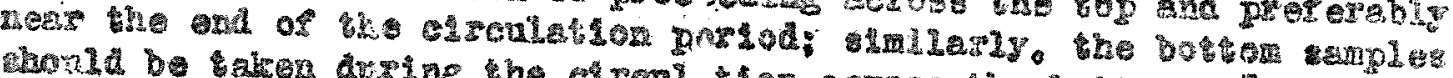

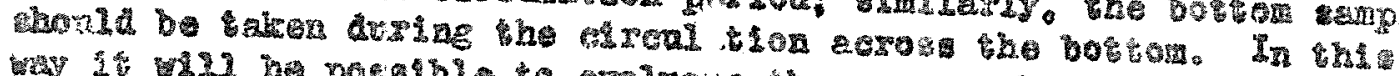

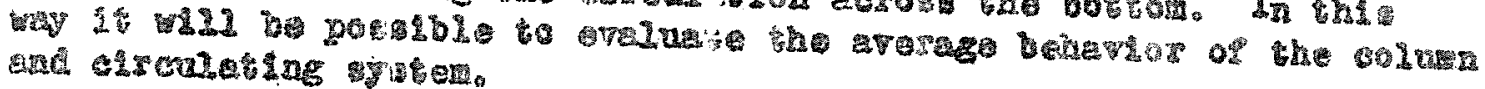

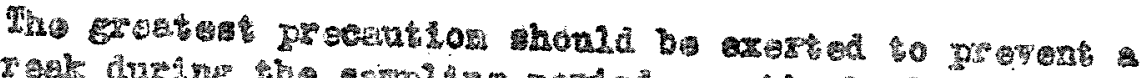

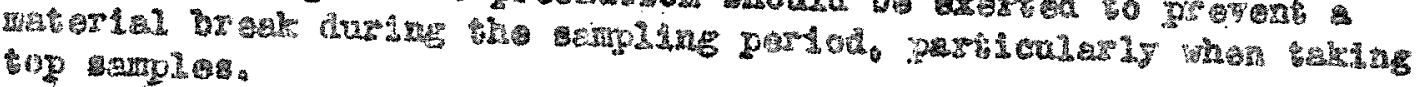

The 5ayco

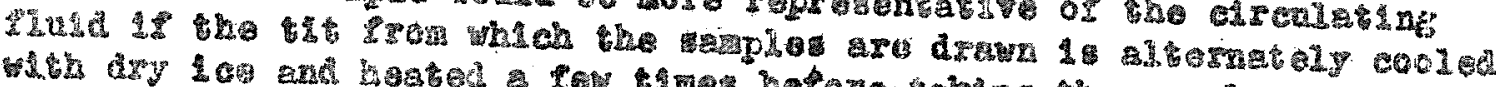

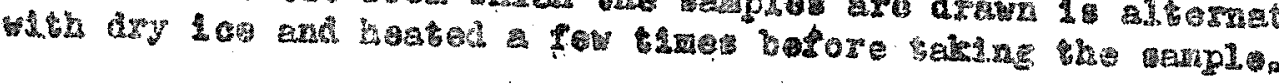

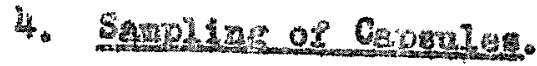

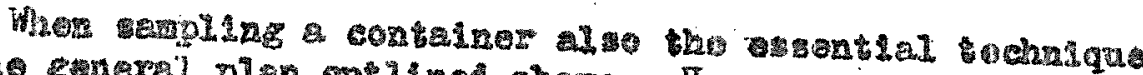

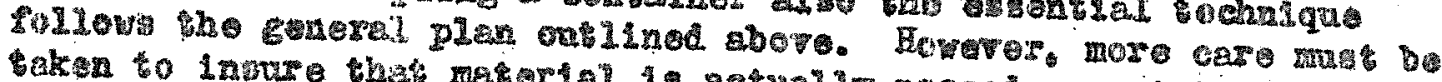

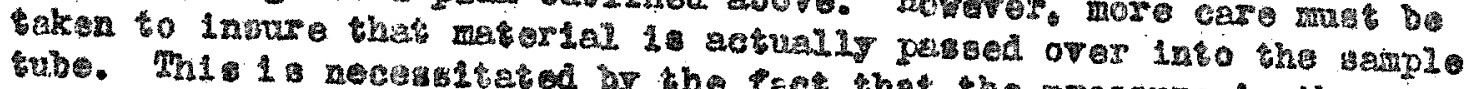

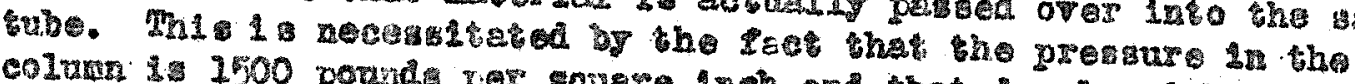

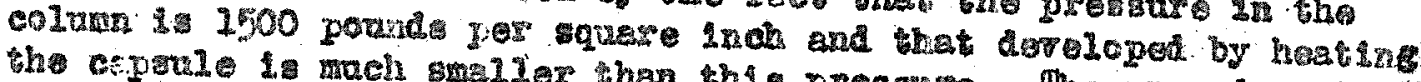

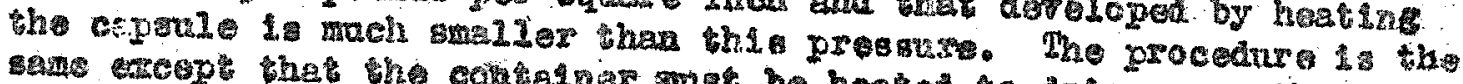

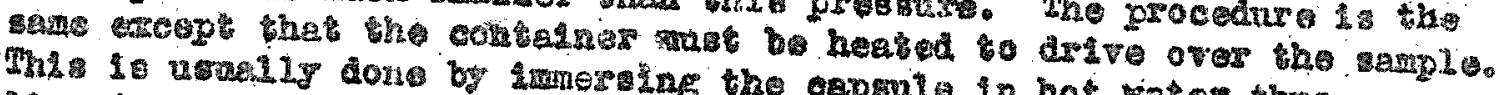

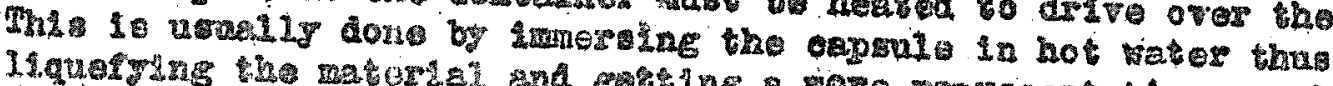

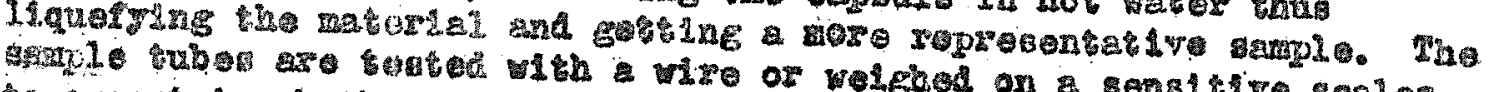

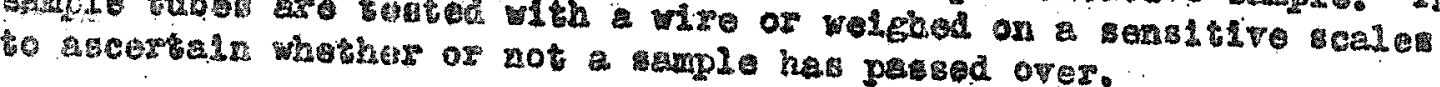

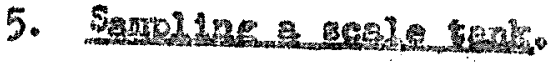

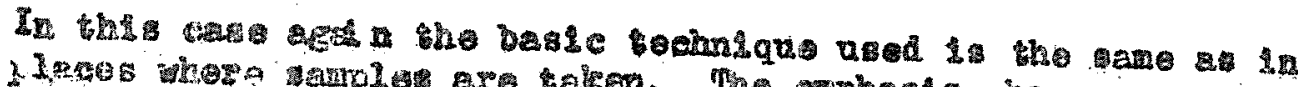

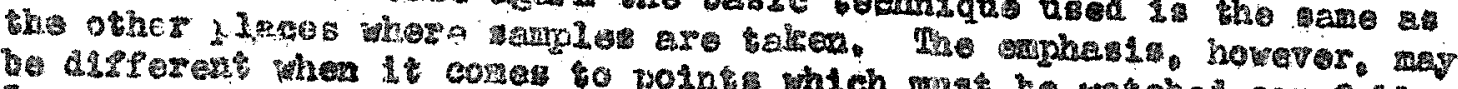

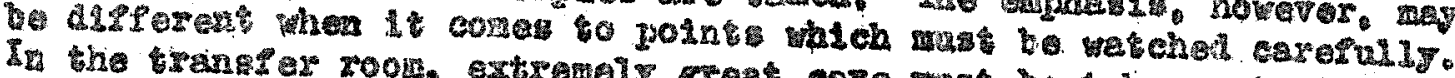

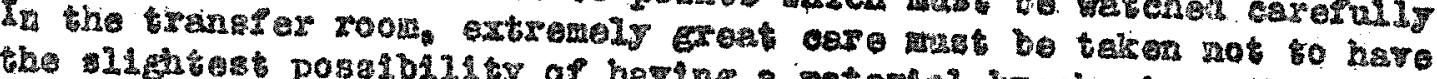
rrvolvwd are sarge.

The ampling of a gente ani 1 not an oregteonally comon

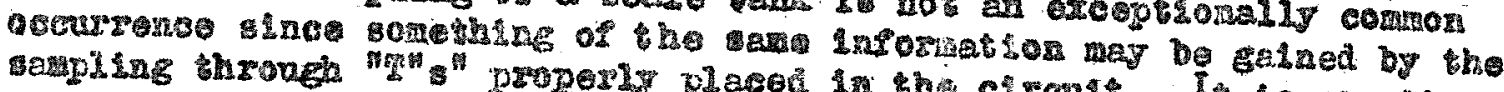

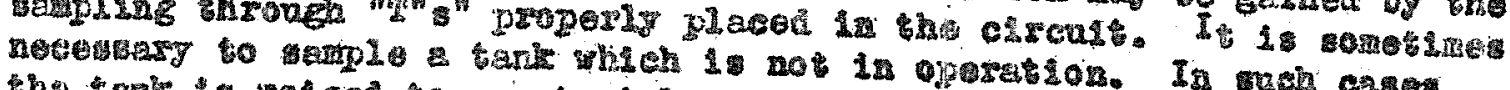

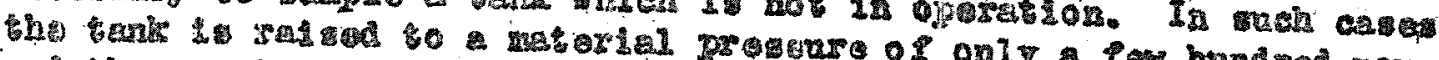
and tho samplo tub plats on tho tse and tho sanple renored.

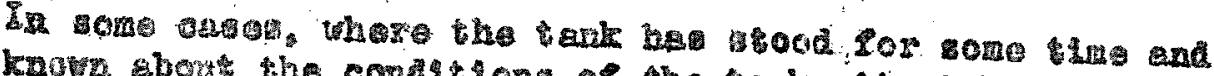

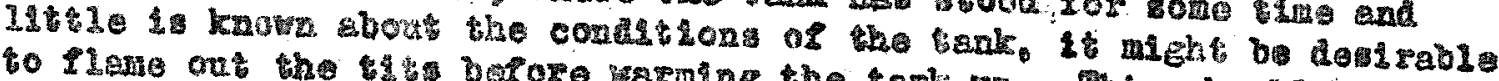

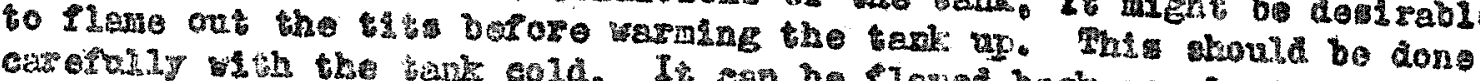

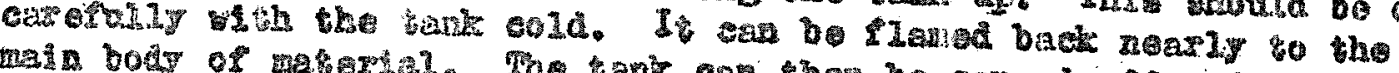

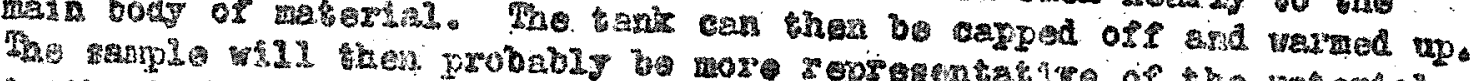

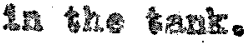




\section{$\longrightarrow$

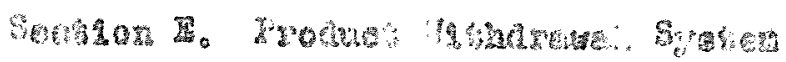

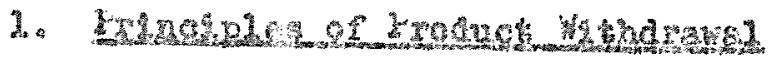

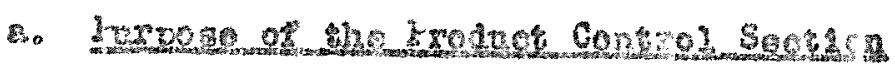

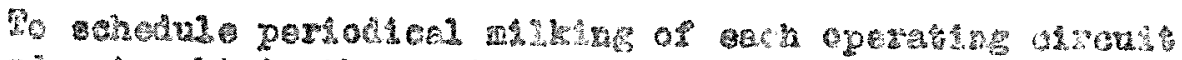

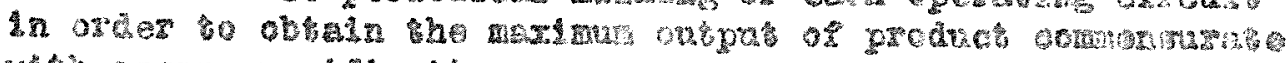

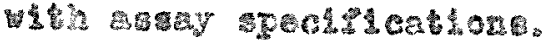

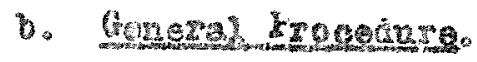

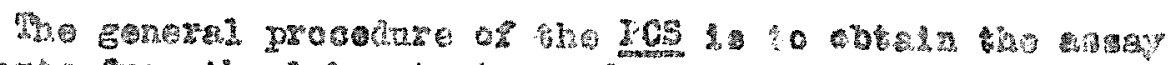

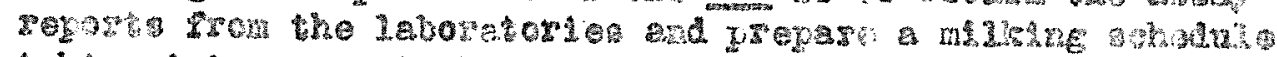
tath

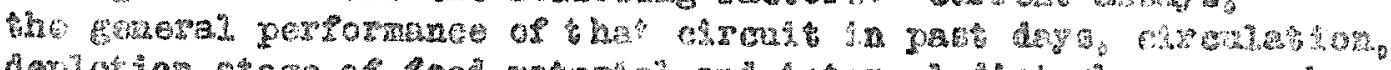

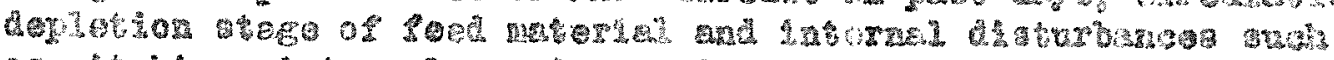

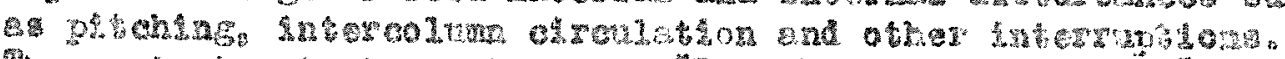

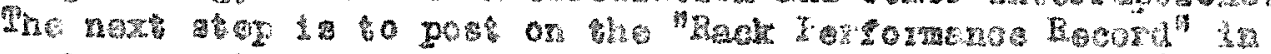

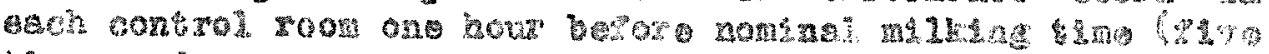

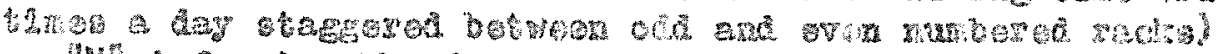

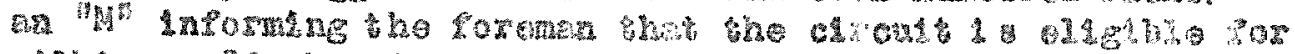

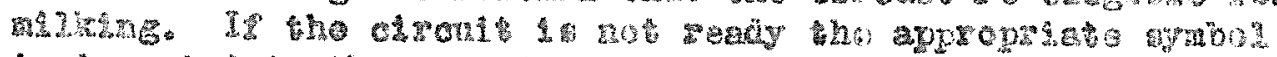

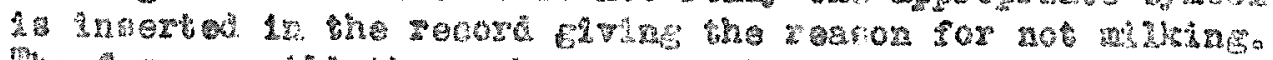

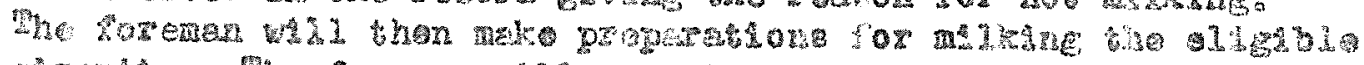

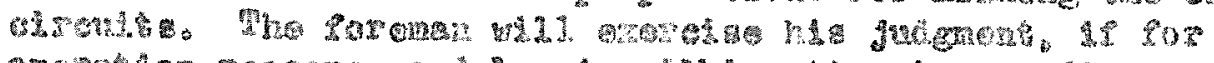

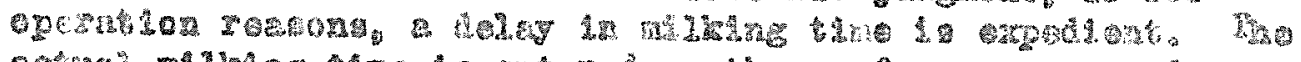

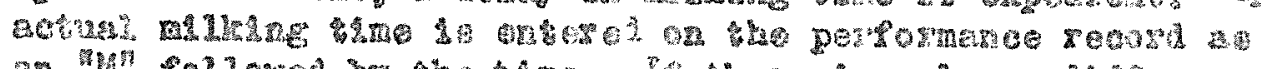

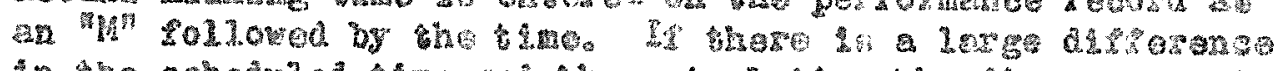

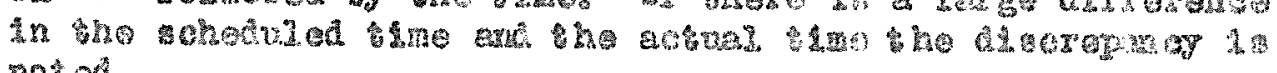
noter.

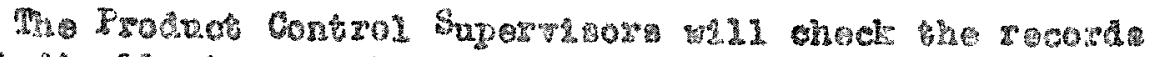

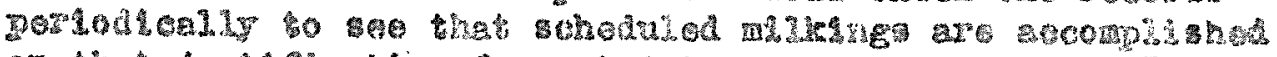

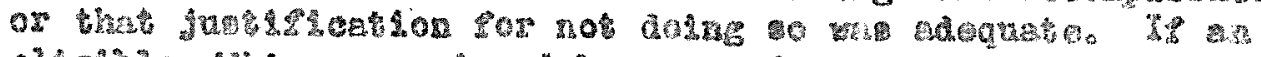

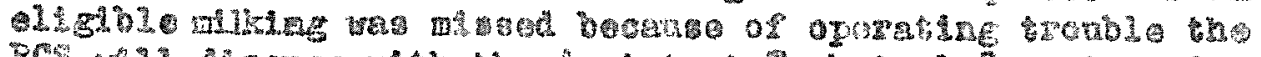

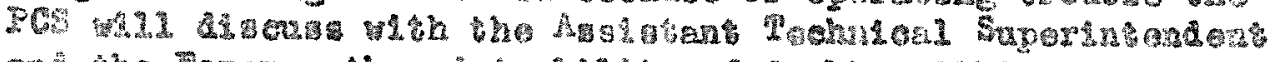

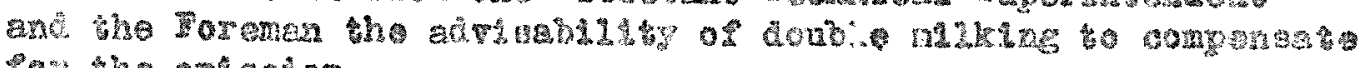

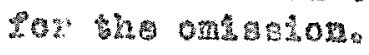

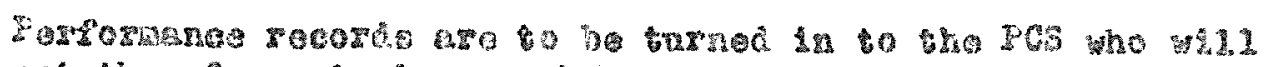
Inspers that for ond

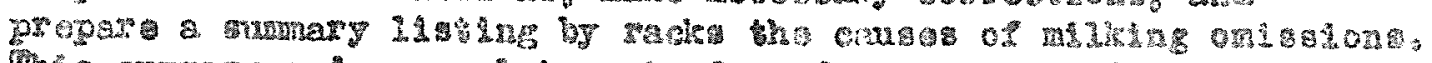
The

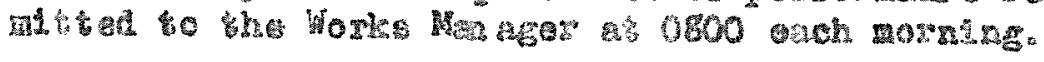

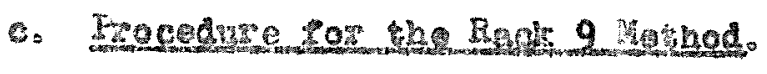

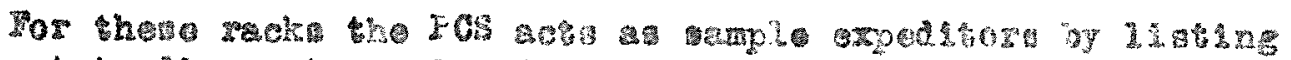

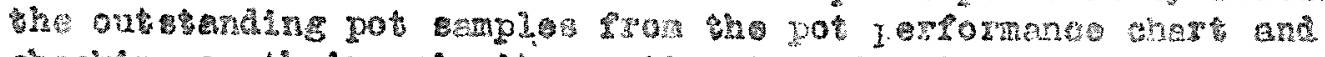

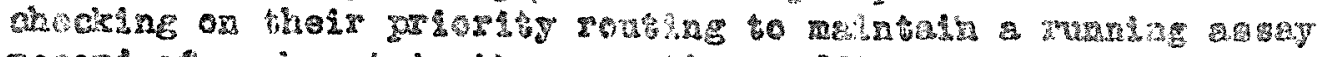

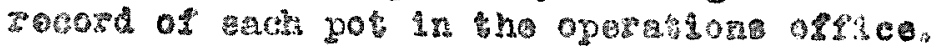

$$
-1
$$


The onglchmon trend of the pot $\mathrm{s}$ then plotted to gat the over-all plcture of the progresa of the pos. On the bast of

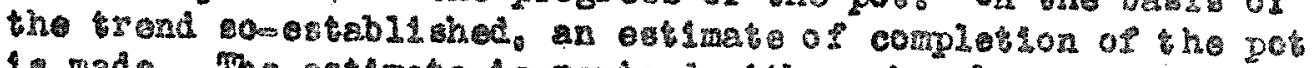

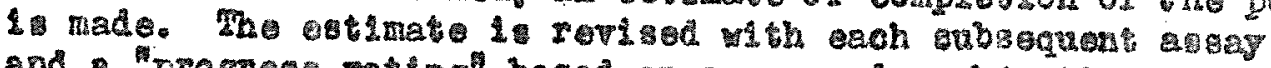
and "grogrese rating" bascd on a sevan day objectivo 1

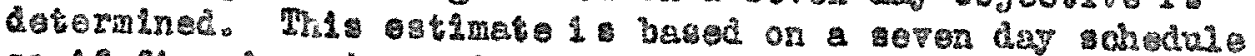

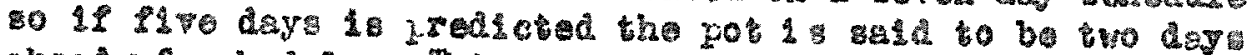

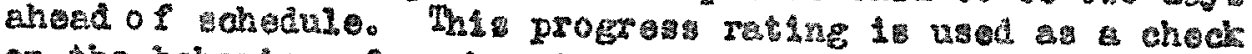
on the boherlor of each pot.

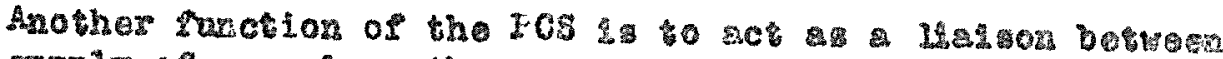

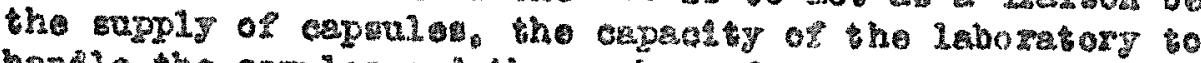

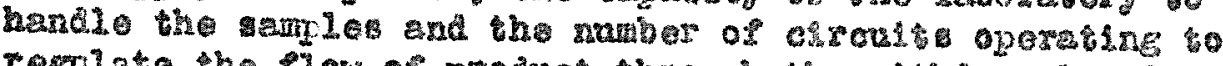
rogulate the Low or product throwh the whidrawe agd shspotng steph.

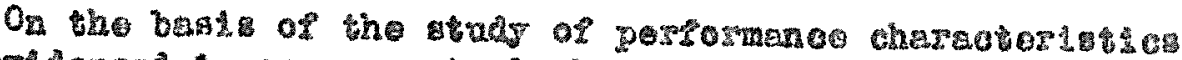

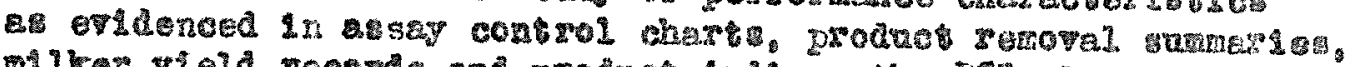

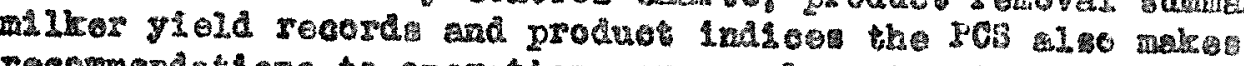

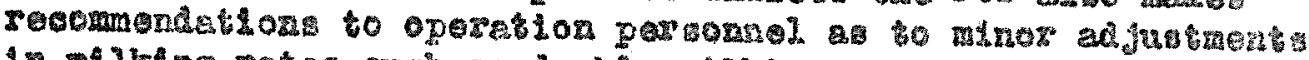

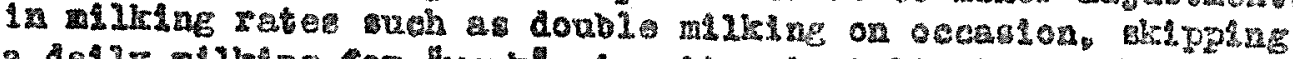

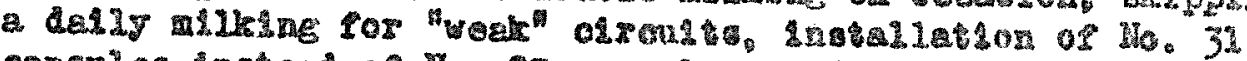

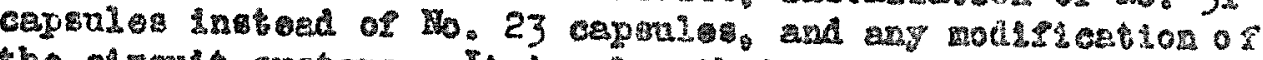

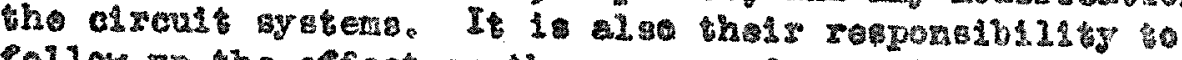
rollow ag the fect on the asay and gaantsty of procret

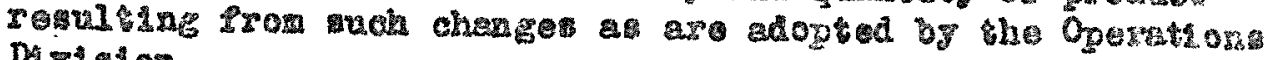
Difision.

\section{d. Sumperz.}

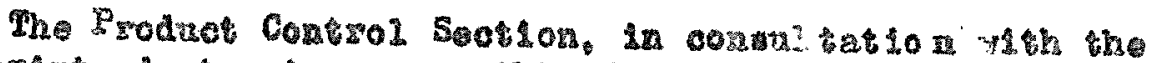

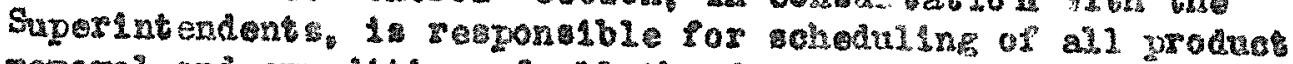

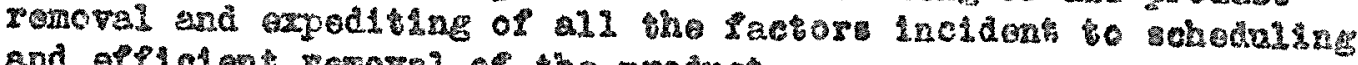
and ofstedent Eenoval of tho produce.

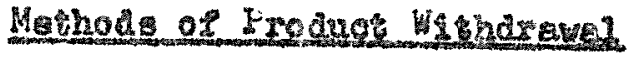

\section{SLnR Colum Muring.}

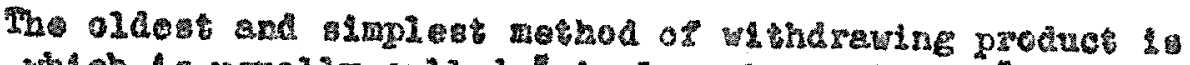

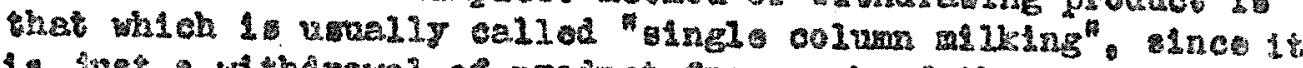

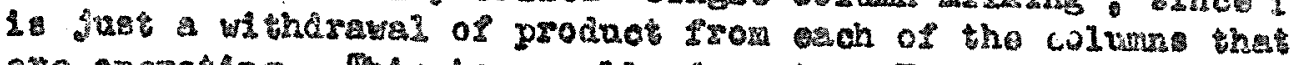

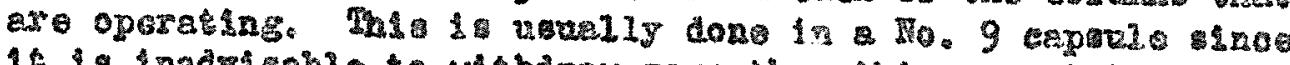

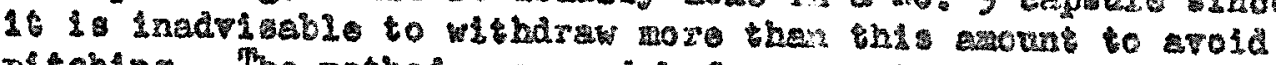

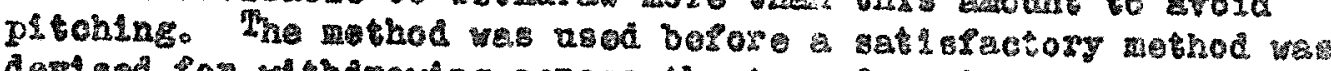

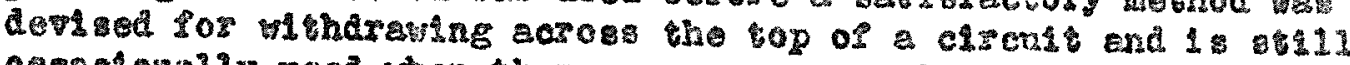
oecegloally aed when there are muneroug pluge that cannot bo locat ed in the top of the circult. Is has $2 a r g e$ s boen mplanis by on of the other wethods which we excecdingly

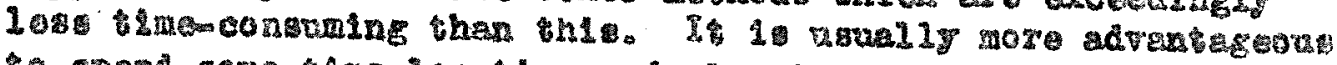

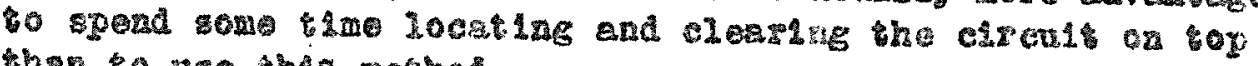
than to use then nethod. 


$$
2-3
$$

\section{b. ManneI Mamorail Mothod}

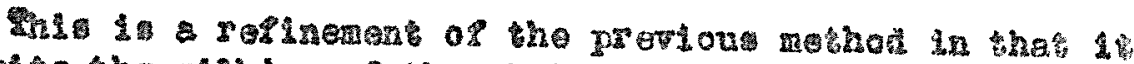

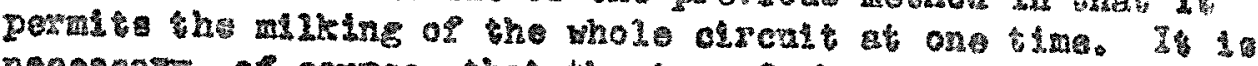

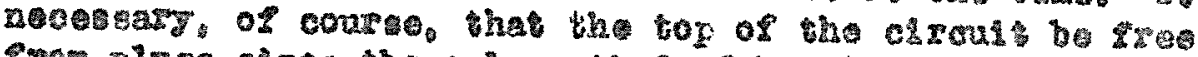
Irow ploes sinos tho only wothot of knowhs whosher of not

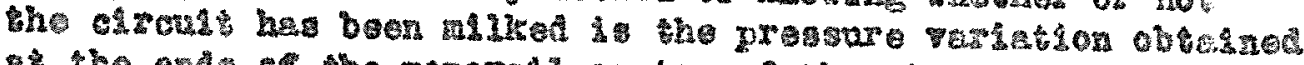
st the end of the motoras or top of she curous.

The circute 10 menaly related to a prosure of 1600 patands

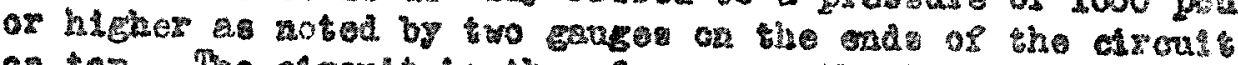

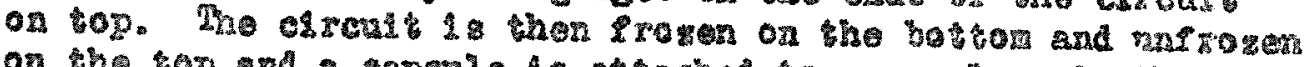

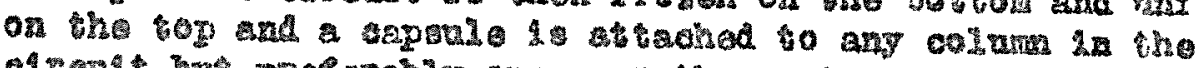
clrcat bat prolerably one near the canser of the gromp.

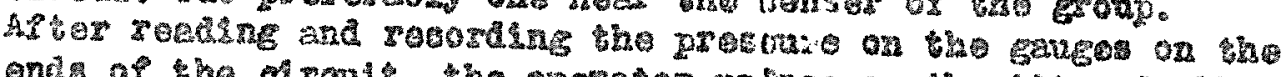

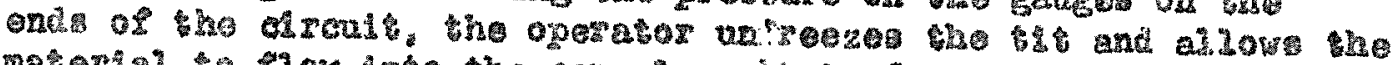

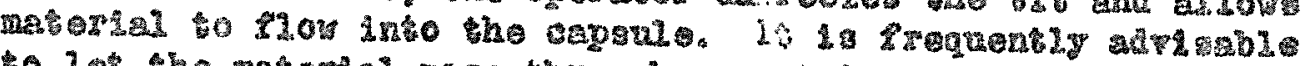

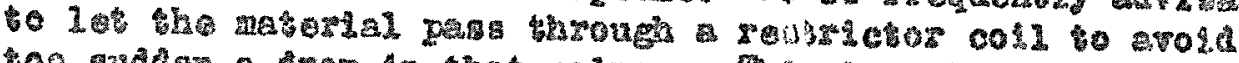

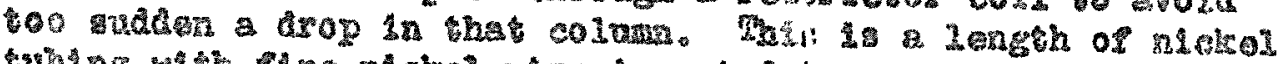

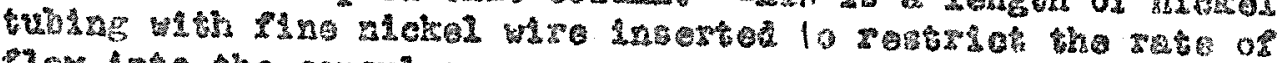
Ilon late the copandon.

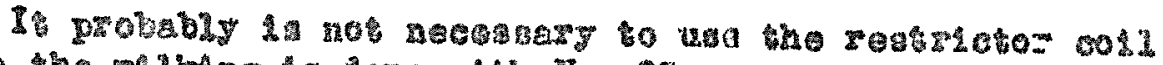

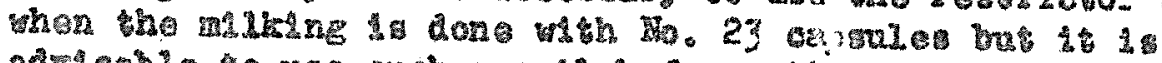

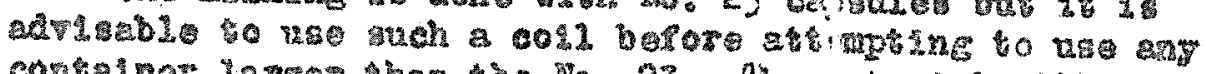

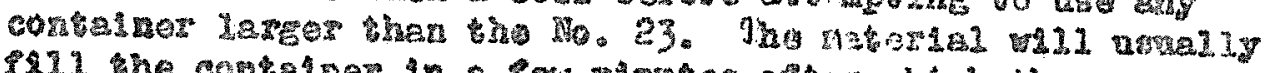

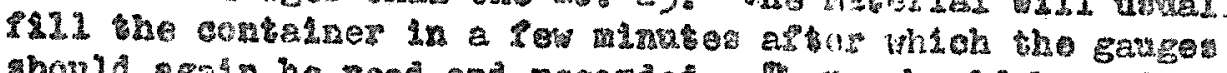
should ages be road and recorded. There thould be a drog

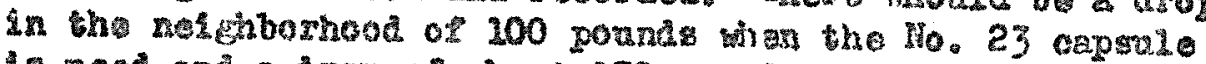

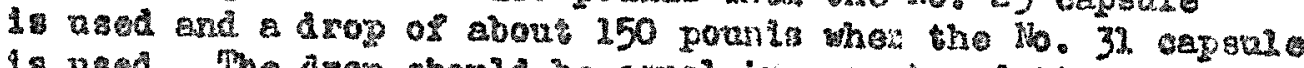

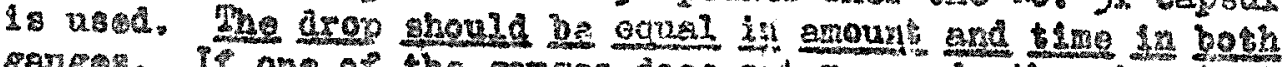

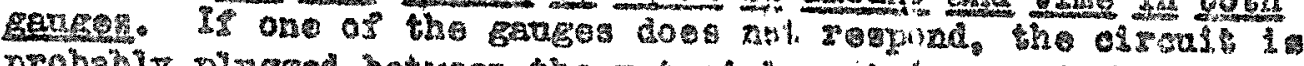
probati pluged botwer the naterial oontalner and the ond

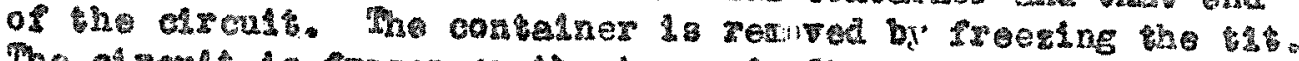

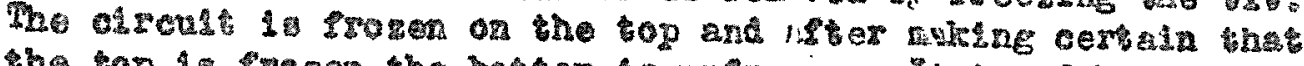

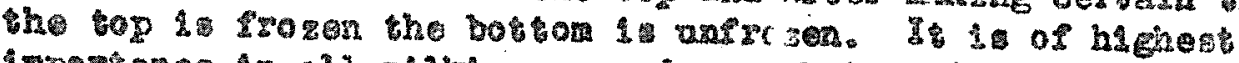

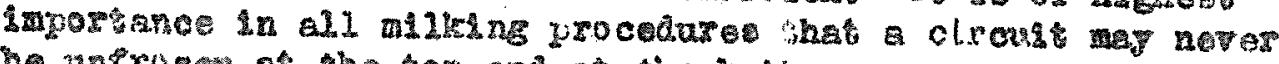
be mincoges st the toy and at tho botion.

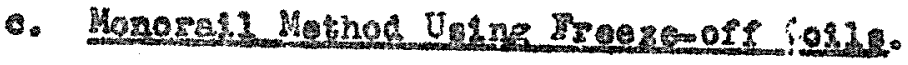

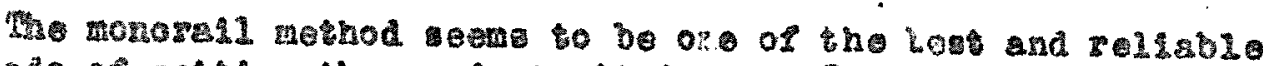

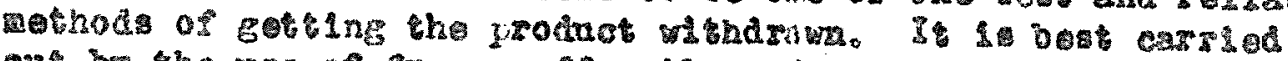

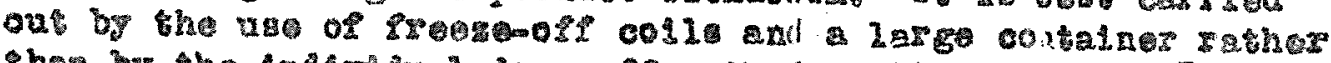

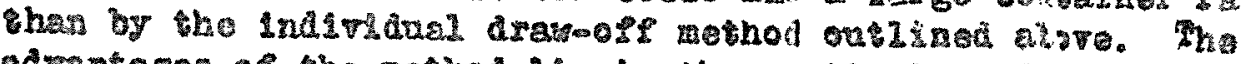

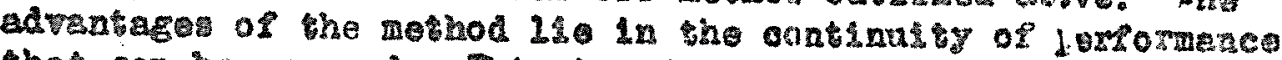

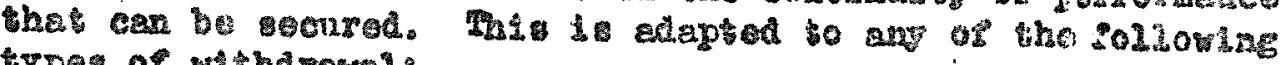
typer of w1thdrawa:

(3) Bansal Eethod

(2) Solenolic ralpo mothod

(3) Can Timer methoe. 


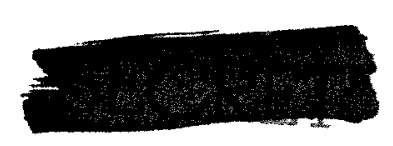

$$
\text { E. } 4
$$

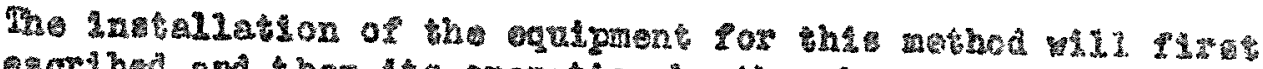
os desarlbed and hen 14 operation by the abov mentanes wethod w12 bo efrven.

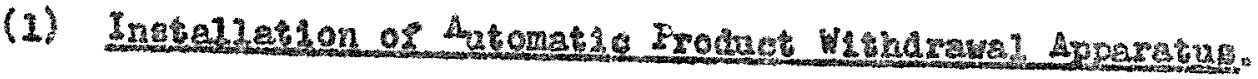

The reps to bo lolloved in thst are givon in the golsow lne oxcer. The parte and oquigmont wey bo gen on the

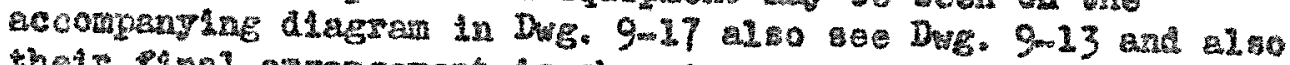
thes Panal arrexcenent 25 homat

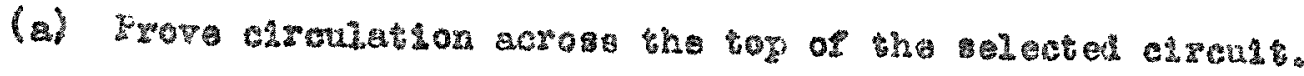

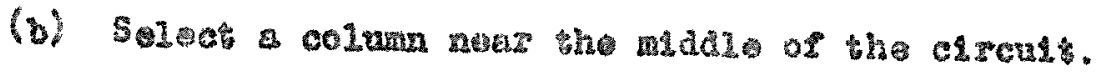

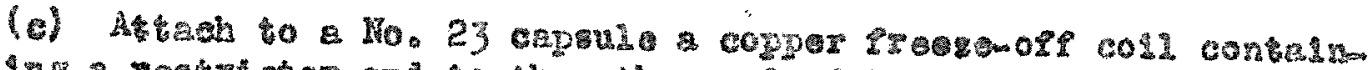

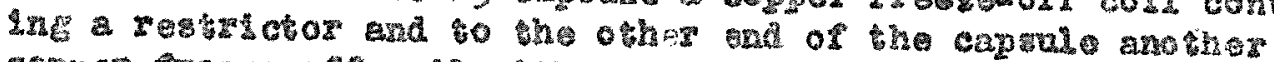

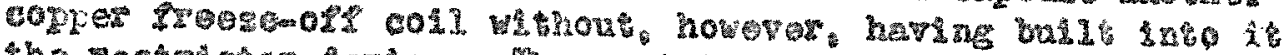

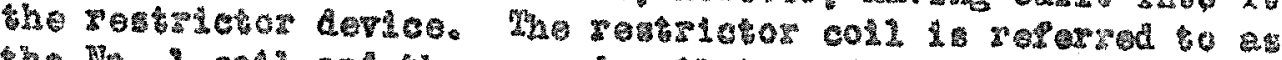

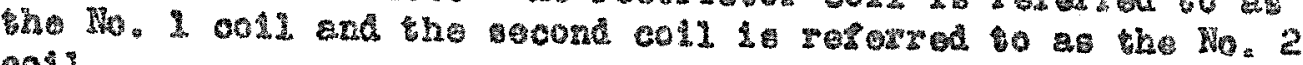
coil.

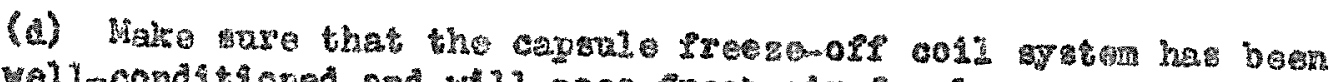

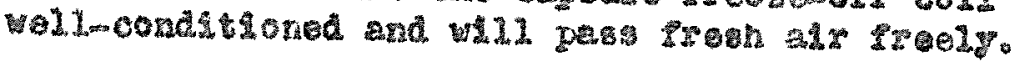

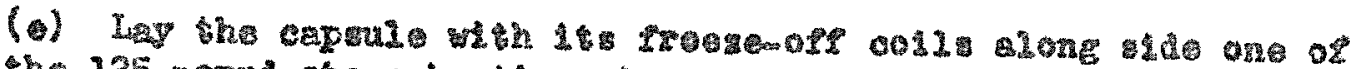

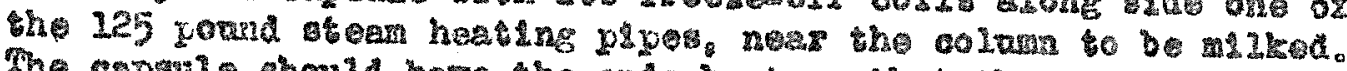

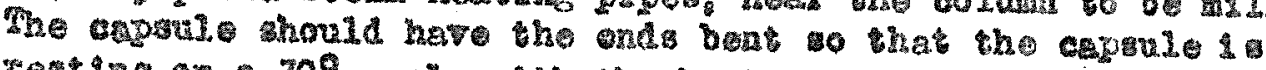
testias on $30^{\circ}$ angle with the host sontal.

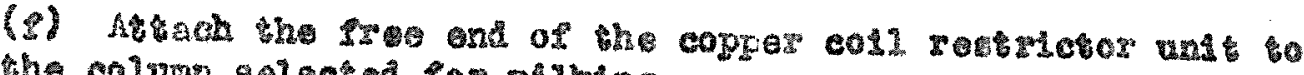
the oolum selectod ror niling.

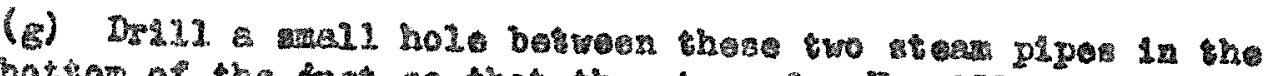
botion of the fugs wo that the stea of a No. 120 coltader w11

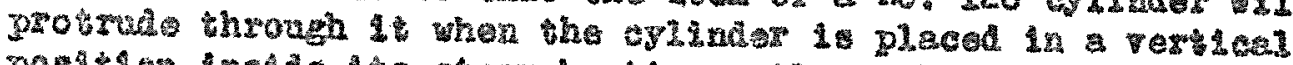

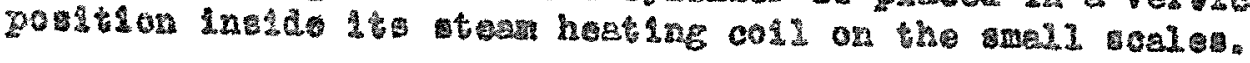

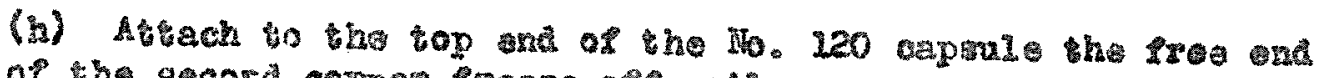

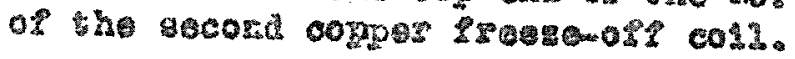

(1) Comect the apper ard of the seper cost to the 5 pound

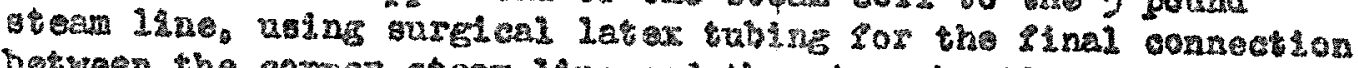

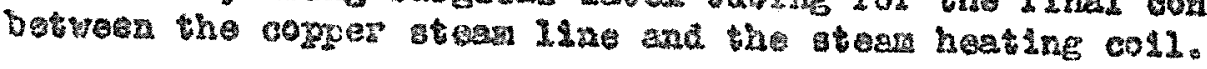

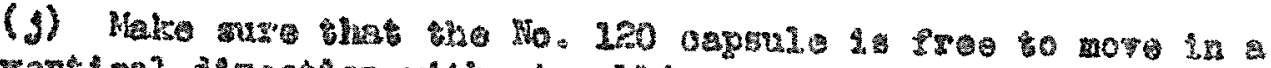
vertides disectson whou jabiss.

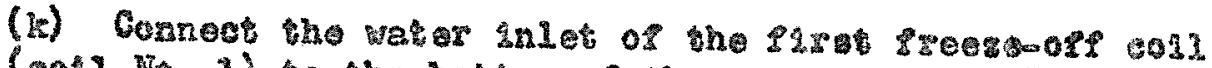

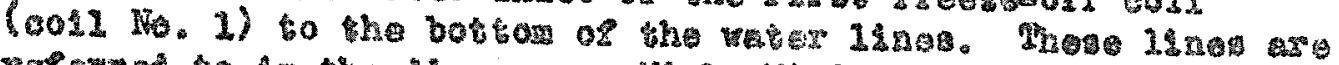

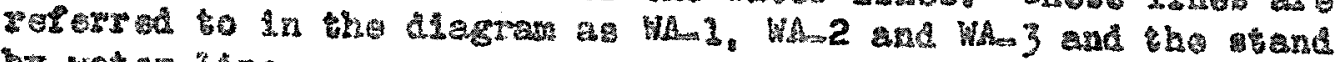
by vatwa $15 n$. 


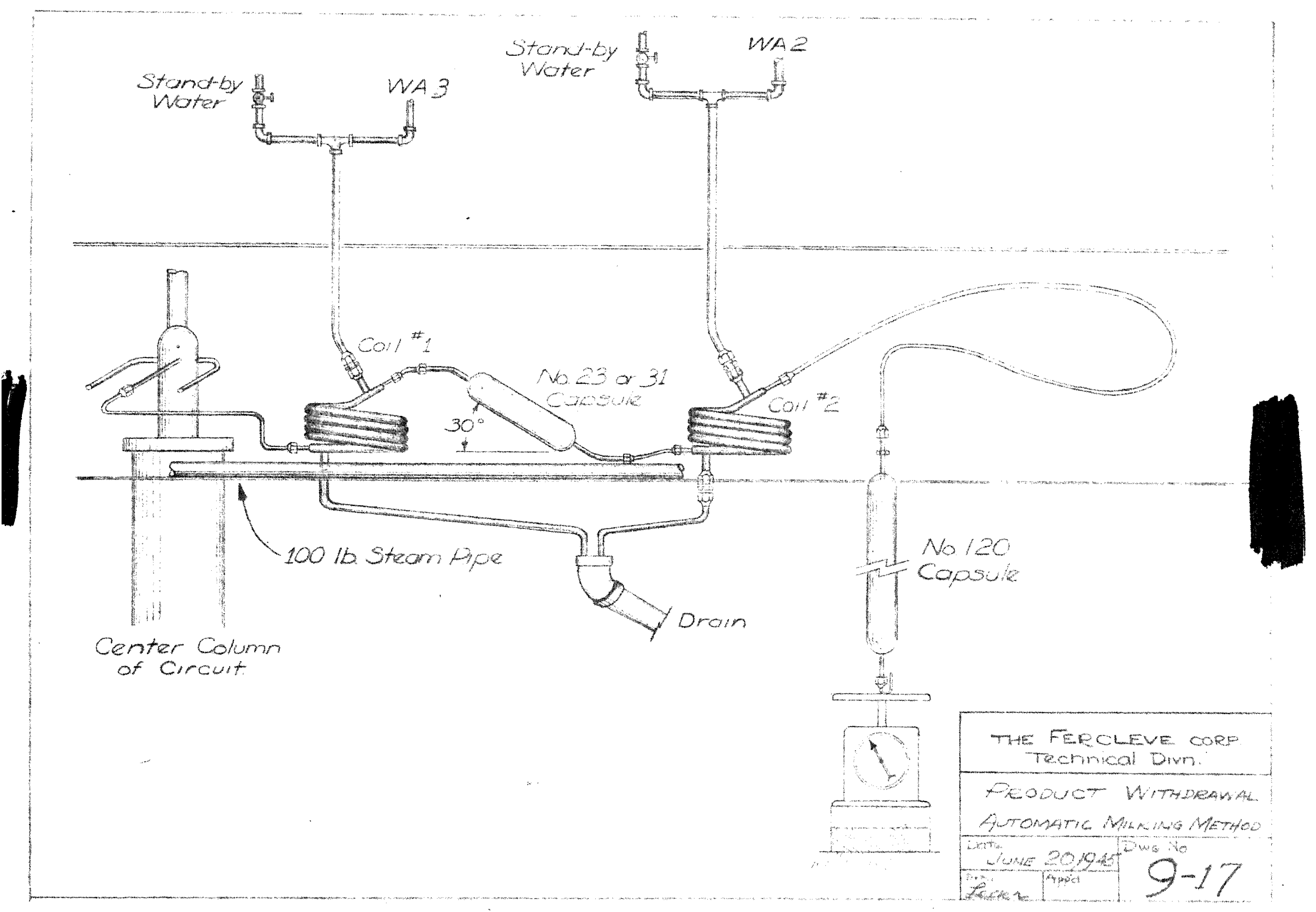


B. $=5$

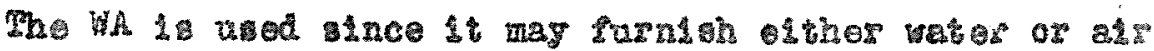
deyonding on whych solenold valpe in opon when those vasas

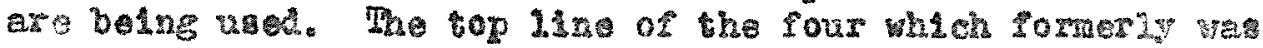
a compressed als lins has been onanged over a waber isne which 2 not controlied by a solonold ralve. The second fron the

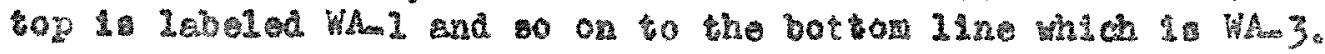

(2) The axis ent of the water $14 \mathrm{n}$ of coil No. 1 shovid be connect od so a po lading to a drain. The iniot ond of coll No. I should also bo oonneoted through a "T" so line What.

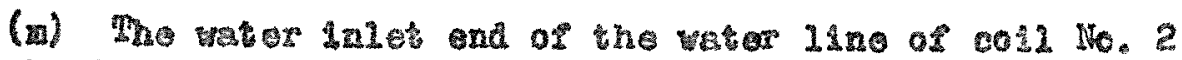

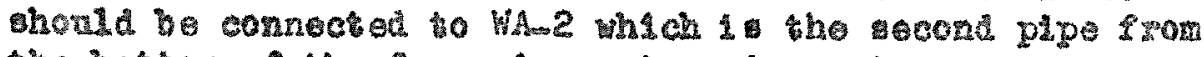
the botson of the four plpo water-ess ageter.

(a) Iy moang of the "In alto connoct the lnier water pipo of Col1 No. 2 to the sop of the alr $11 \mathrm{n}$.

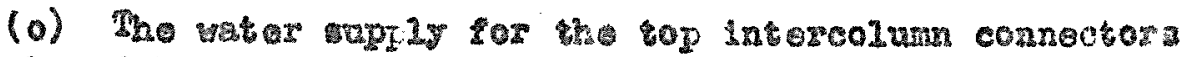

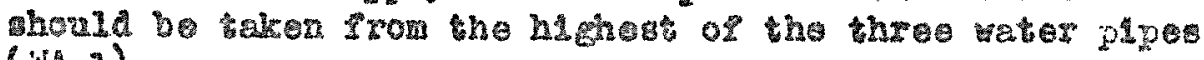
(WE-1).

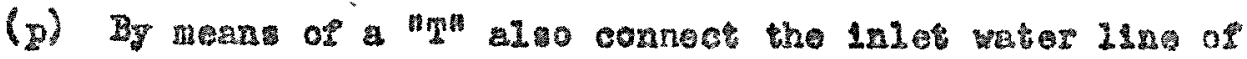

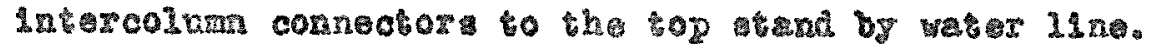
Co1g.s.

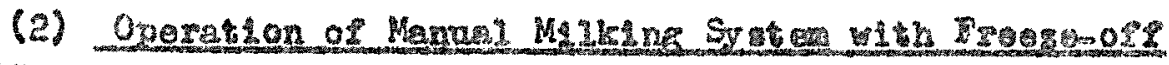

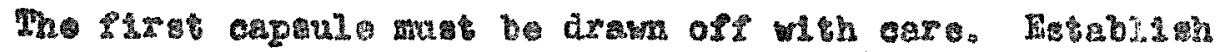

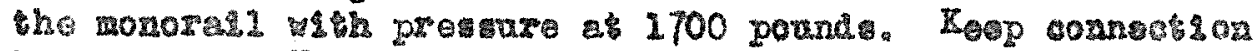
botreen coll Wo. 2 and the No. 120 caperio plugged uith

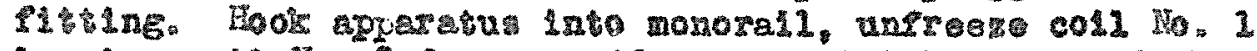

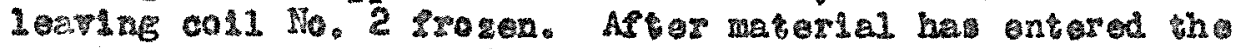

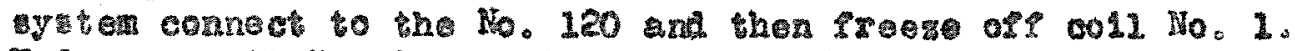
Unireeze coll No. 2 and distll orer. When material io in tho

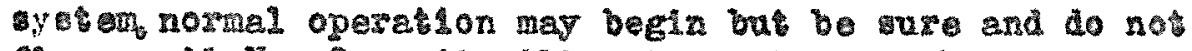

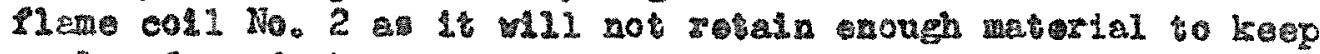

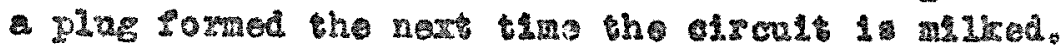

The soledule sor normal operethon mey bo lollowed aprozmately as 10210w:

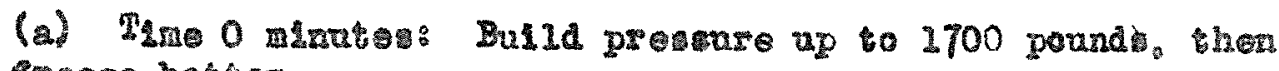
2rese botson.

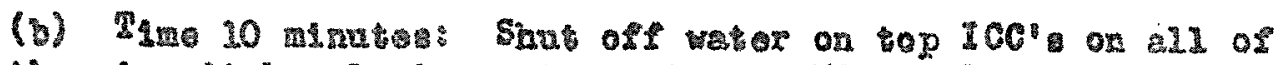

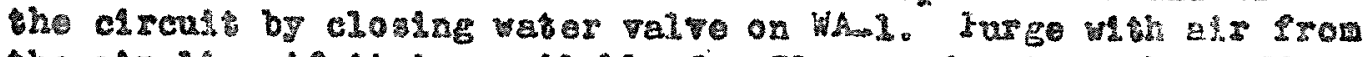

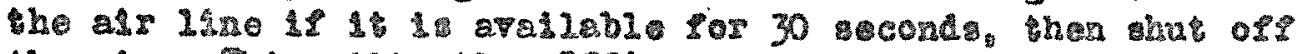

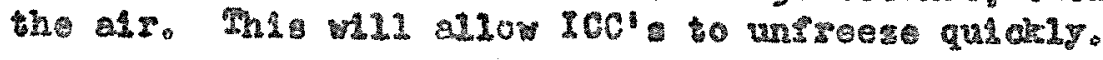




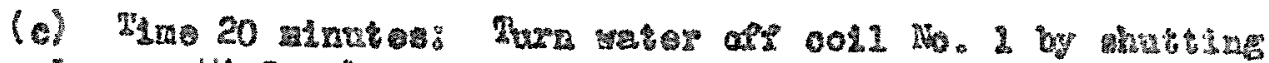

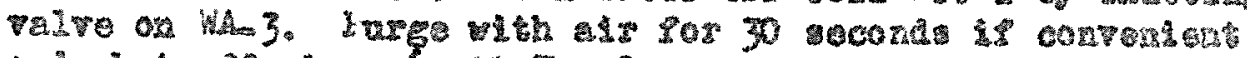

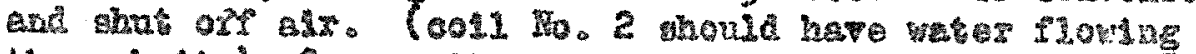

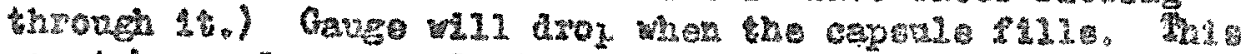

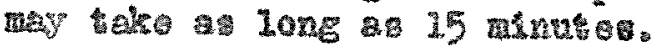

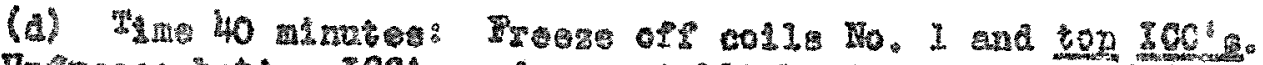
Unes

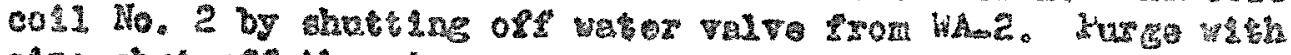

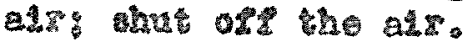

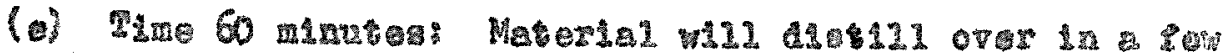

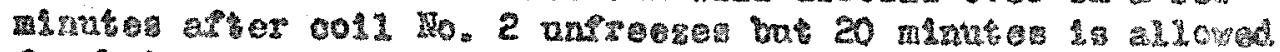

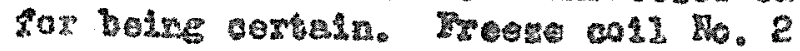

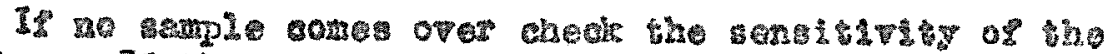

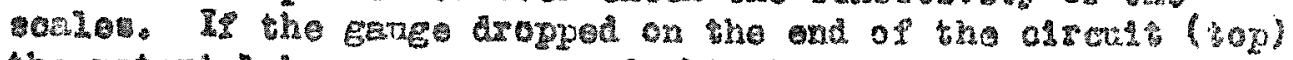

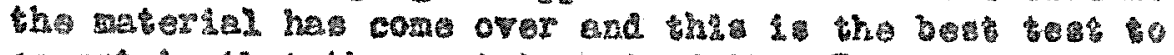

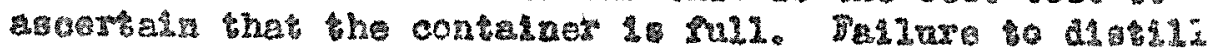

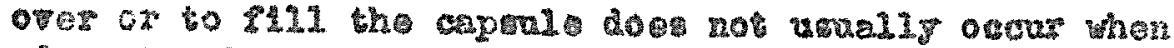
adequate sime in allowed.

Nate pary cortaln that the operator record the rewuly of qach dran-as? on the tad sheot. Tak ors the No. 120

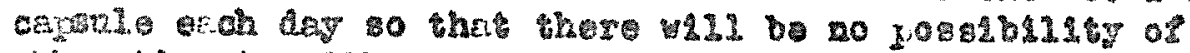

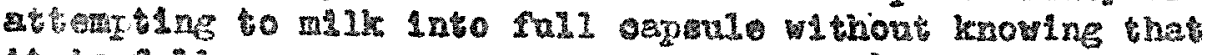
it I. โบ11.

\section{(3) Instruetiong for Opexstion of Antoneste Minking} Apzazetus Ualng tho Solerold Volve Srotera

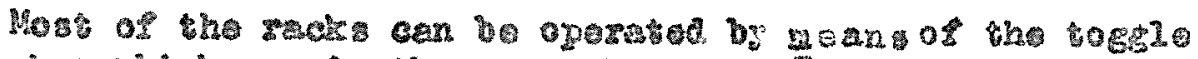
switheres this are In the whrol zoom. Thay control the solenold ralvos as the top of the reck through whloh vates

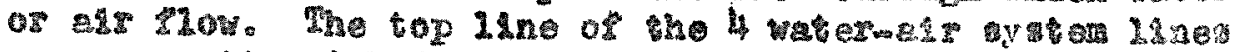

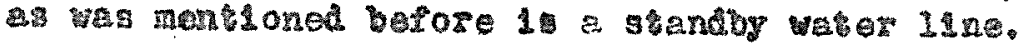

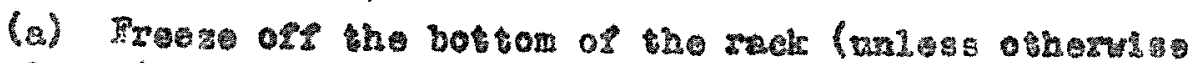
altered, the thole reck is proven off at tho bottom at

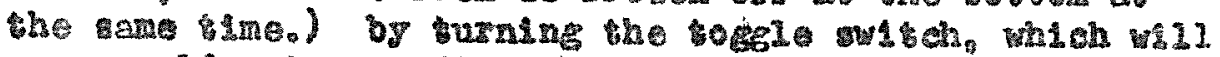

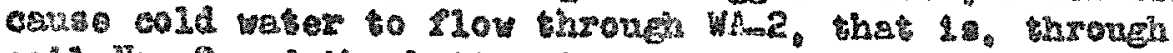
col1 No, 2 and the botton intercolusan connectors.

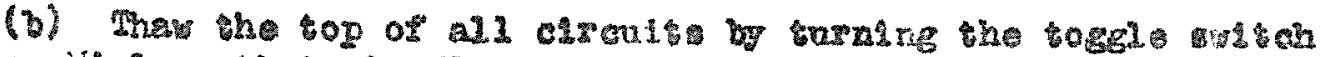

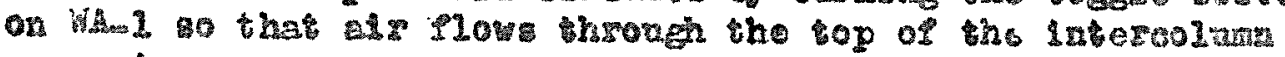
monectors.

(c) Was 20 minate.

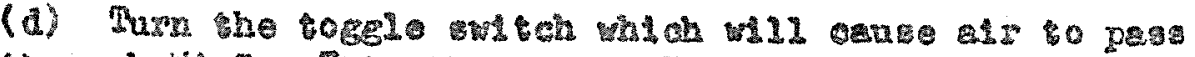

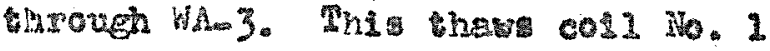

(6) Wast 20 minutes. 
$2=7=$

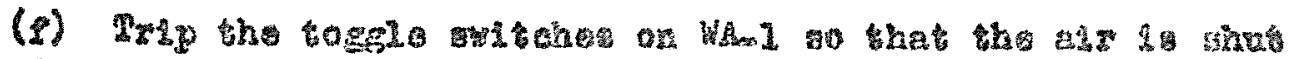

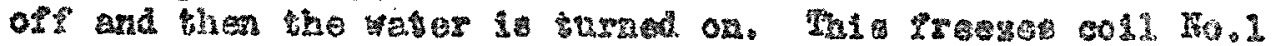
and the tap kntercolum connectoss.

(E) That the botson of the arone by trigptng the togeto

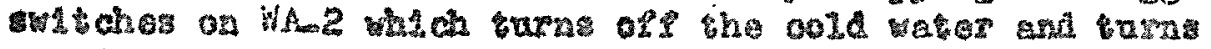
on s 12 through col2 To. 2 and the botrom of the sutercoinan aomingetos.

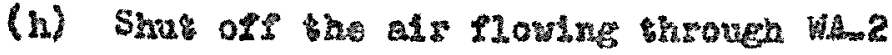

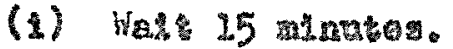

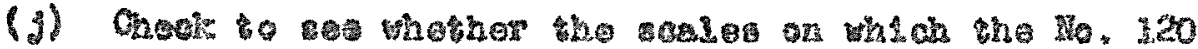
cyind

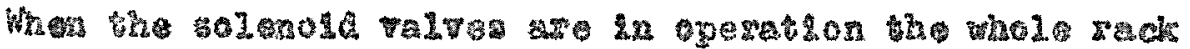

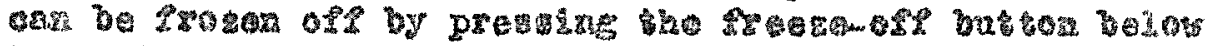

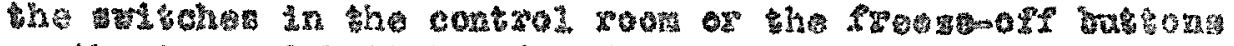
on tho hog and botton ond of the sect.

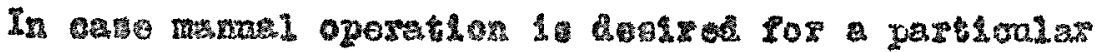

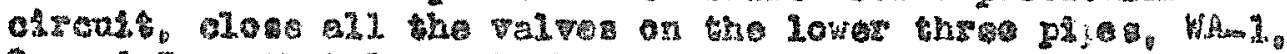
2. and 3 on thes 200p, both bog and bostom, and control tho thot

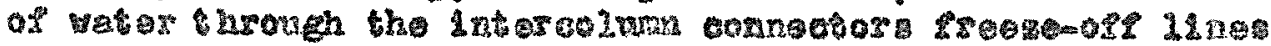
by nean of valves on the p poo 2129.

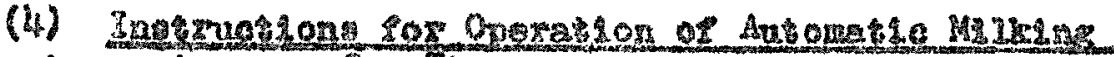

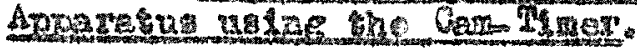

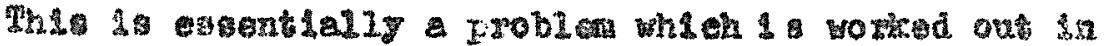

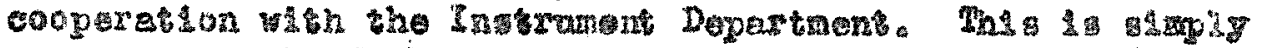

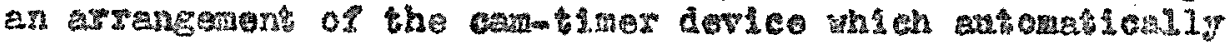

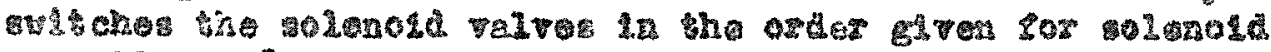

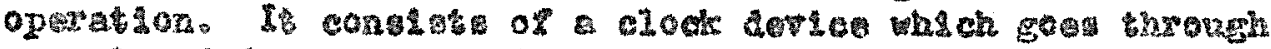

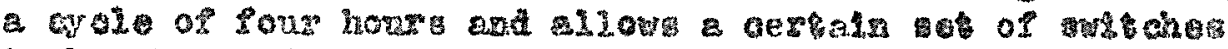

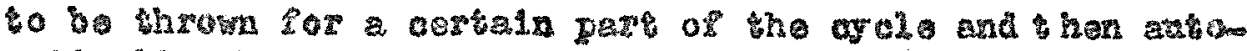

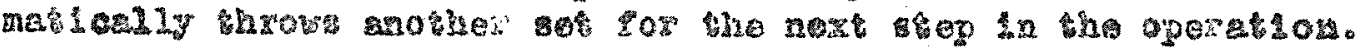

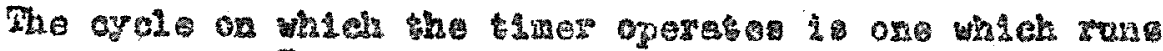

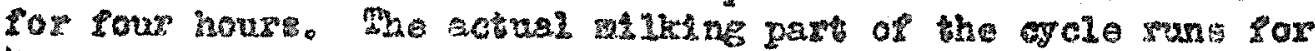

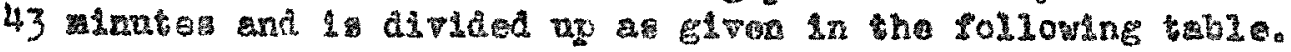

\& or cyes

T.

a

$2-1 / 2$

$2-1 / 2+4$ $3-1 / 4$

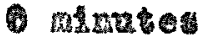

6 and anto

$6+$ $-3 / 4$

Sazy of Iractis

Wasto on botsom, N. 2 col1 Waser ols top

A2x or 6อบ

As 089 of

(contsaned or noxt gres) 
$2-E^{2}$

\% of Cyete

$8-2 / 2$

$8+3 / 4$

9-8,

$25-2 / 2$

$35-3 / 4$

$17-1 / 2$

$27-2 / 2 \cdot+$ $18-2 / 4$ whe

$20-1 / 2$

2I

22

$37-2 / 4$

$37-3 / 4$

$42 t$ 5ext of provens

Haser OS2 150.2 cos.

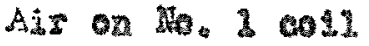
Ais of 180.3 cos Heter on No, 1 coll Water on sop Wast of

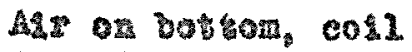
A 5 of of 
I -9

Fog

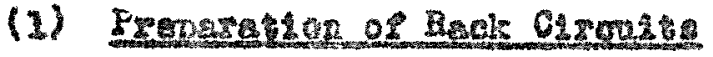

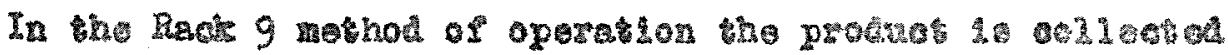

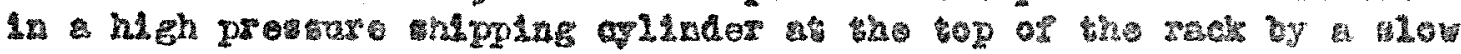

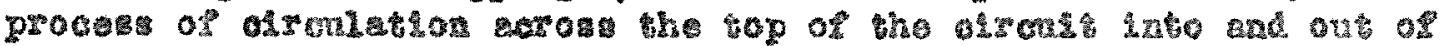

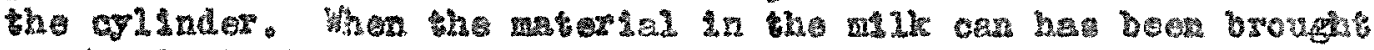

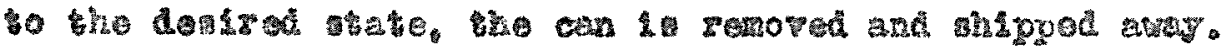

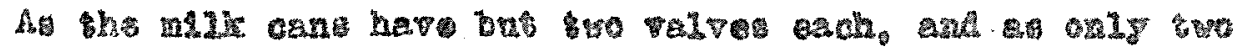

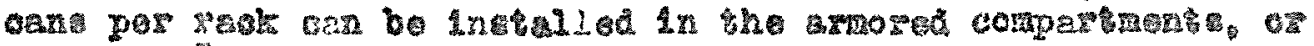

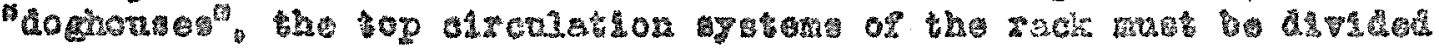

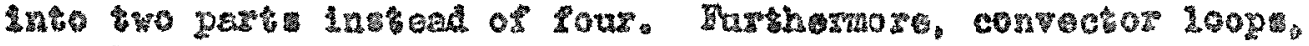

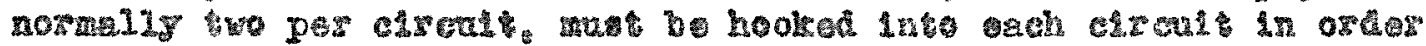

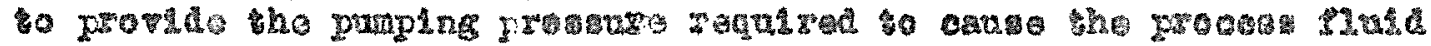

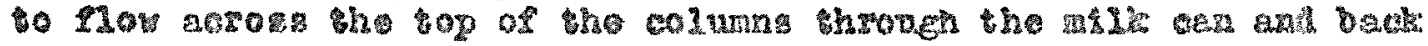
agasta

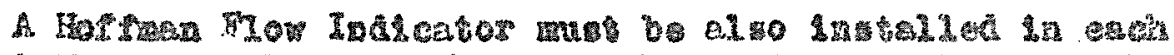

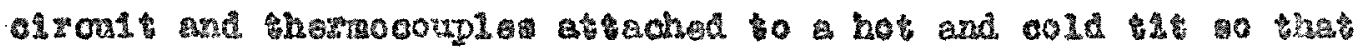

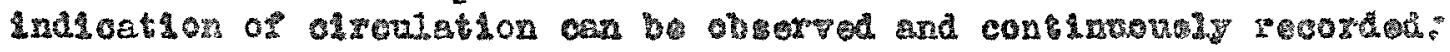

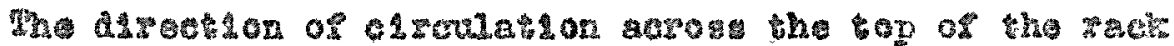

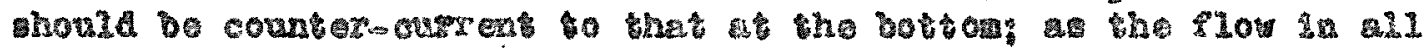

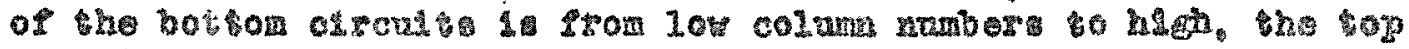

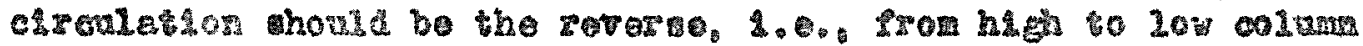
number.

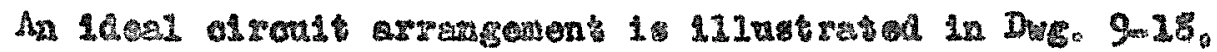

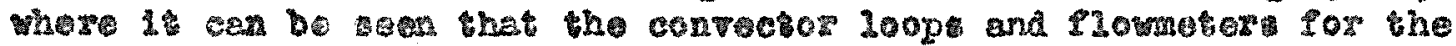
top and botton ofstista

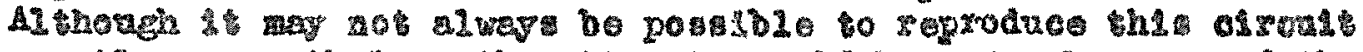

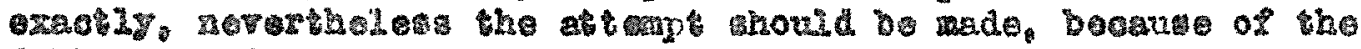
rolsowns advantagas:

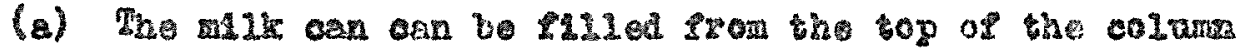

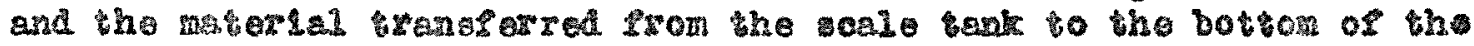
colvens vithout the necessiby or gotne through any convechor loopg.

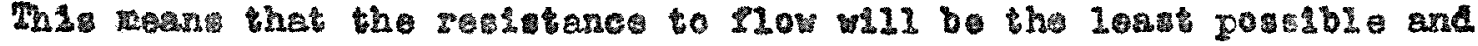

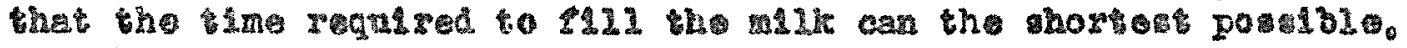
vonethine grand to be degred.

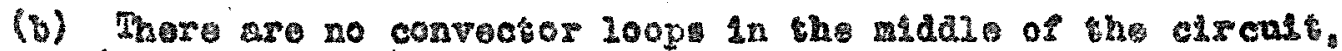

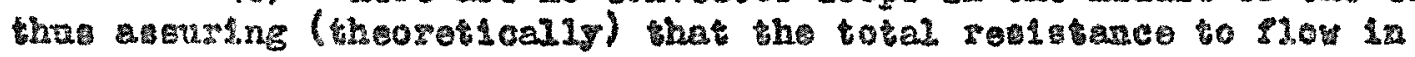

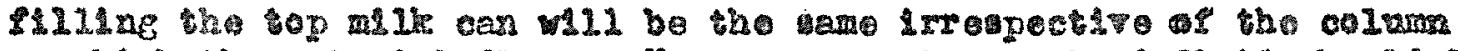

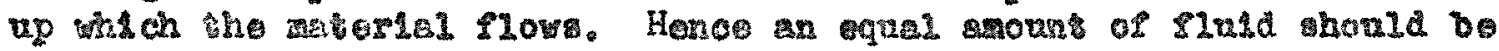
rewored from ech colvm. 


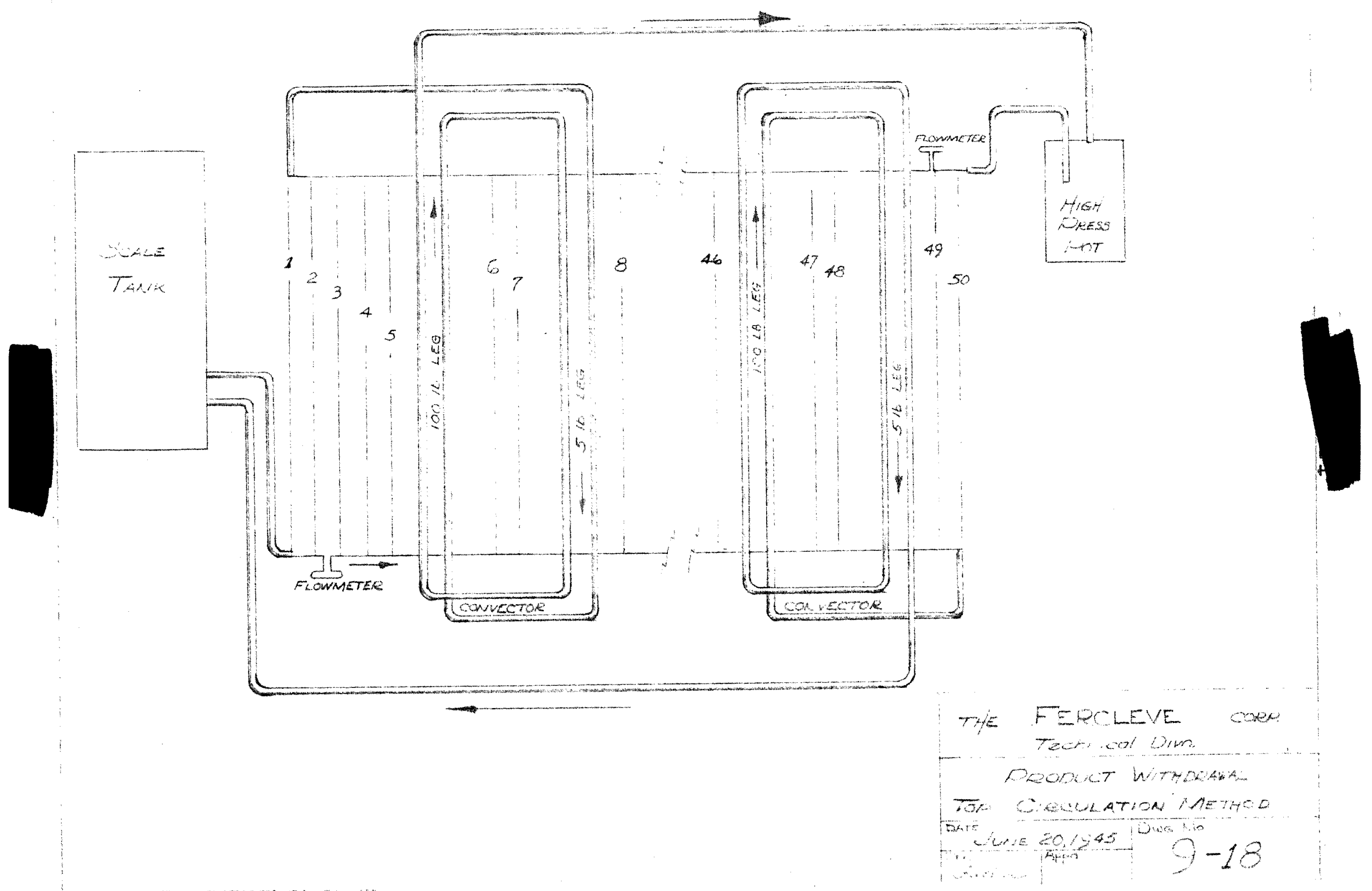




$$
\text { 5. } 10
$$

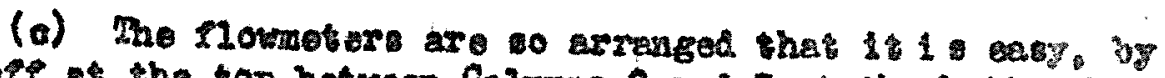
rteozing oft as tho top between Colwne 2 and 3 at the botton betwoon

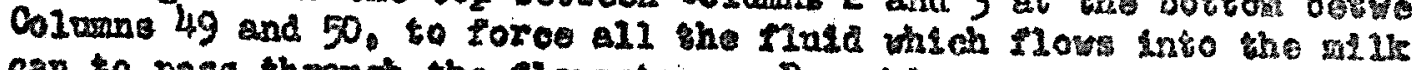
can to pas throngh tho Ilometers. By ming rasisnge of weleht

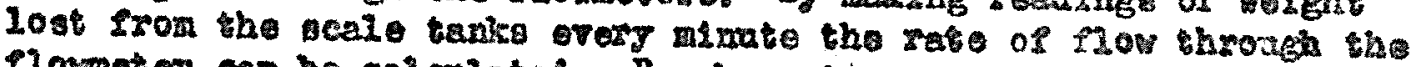
llownot or an be calculated. By obcerving at the aame the the teraporam tures Indicet by tho nercury thernometers the thouneter can be callibrat on.

Howevex, in case chrouiaton in ethes of tho top on bottom

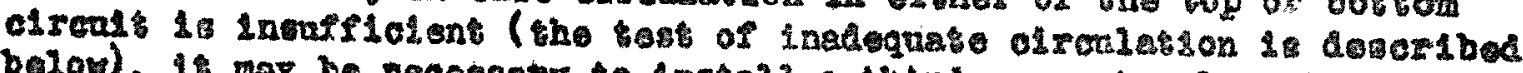
bolon). it may bo neoeteaty to install a third convector $100 \mathrm{z}$ in oah olrents. The extra conveotor loop for the top ond betcon ol boudl bo velected from the mane group so that the lcope util ba betreen the sems colunn. Othorvise the total rostatance to tlow sn f3ling the milk cans wil be differest in alfrerant pasts of the

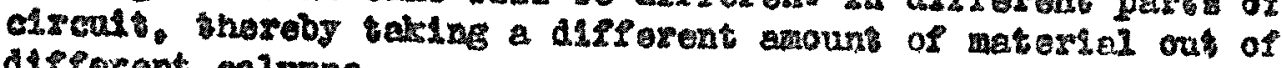
dselorent columns.

Tho outer condut is ach terminal bex ant convectora number 2 and 3 showd be uned to theg have largor IDt than the othere. The total reslutanos to fou should be reduced to a aldimas.

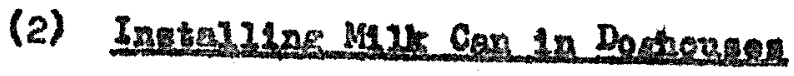

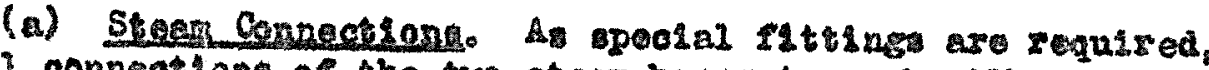

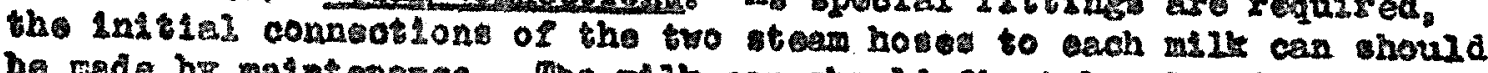

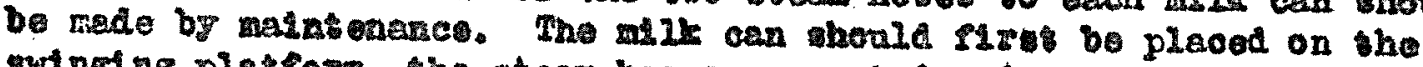

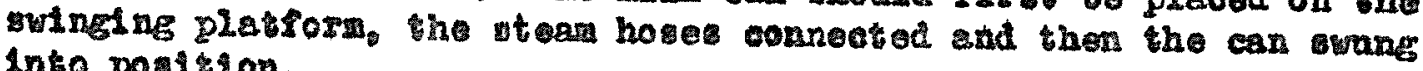
Into positzon.

As 112 be resmphsstad below, the team preasure on the

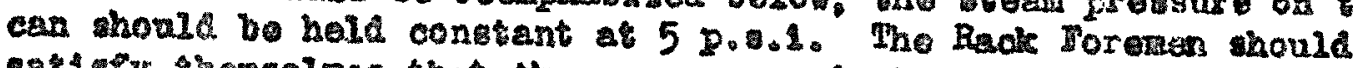

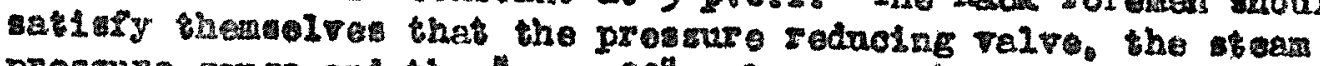
prossur genge and tho "popoos"s" valto are all in good working

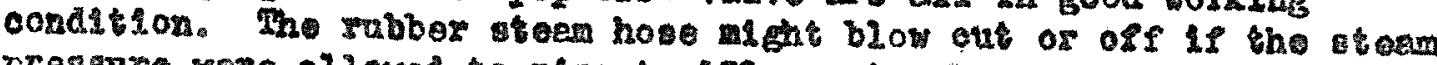

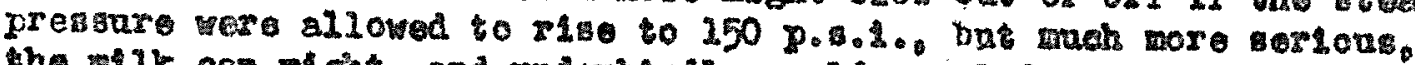

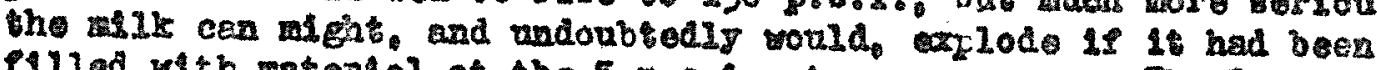
111lod with matorlal at the 5 p.s.1. stean prossure. The lack Foreman should alwo mak sure that tho stoan trap 1 not pluged and ho ahould varn his orew members to guard continosis agelnst tho becking up of cold weter into the steen jecket of the ullk can. A dangerous situation would bo oreat ed it the milk can wore allowed so cool down whs in

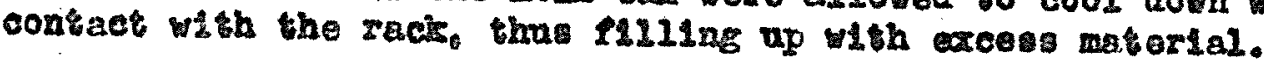

(b) Matertal Connect1ong. On omch milk cen thare ar two valves. one masiced on the can neas the base of the velve with an

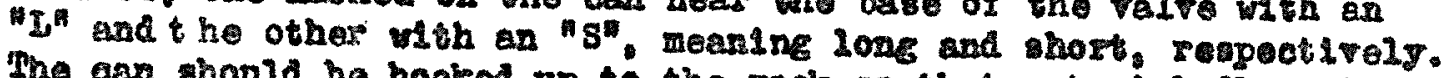
The aan should be hooked up to the raek vo that nateriel fiows tato the can through tho ahort valvo and ort the long ralve, althongh this is not a vory amportant coball. 
Bach Kerosest valve has to have an adater attached to 16. and mado thght using a copper waher. The adapiers whowld bo installod by Baliou ' Dopartment. The ract czow, howerer, ohoula mak sure that the alokel threads on the adapter are in good condlston. The nickel throads on the male tits at the end of the conduis Trom the rack ohould also be ingpocted. An unnoces aery aroun of time of meny good mes in the plant has been pent strageling wh poos

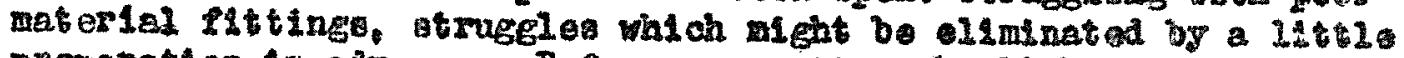

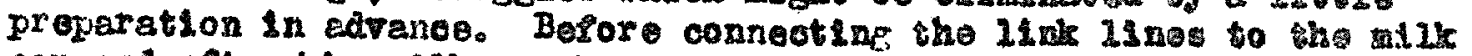
can and ater the mils can has bocomo hot orack esch gerotect ralro to make bure thet material sunes can blow out; in other worde, that the valve are not plueged. The ralvo should bo conness bo the

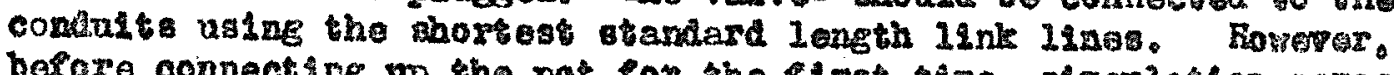
before connecting up the pot for the first timo circulation acros the top of the cixcut ahould bo proved by attaohing a jumper betreon

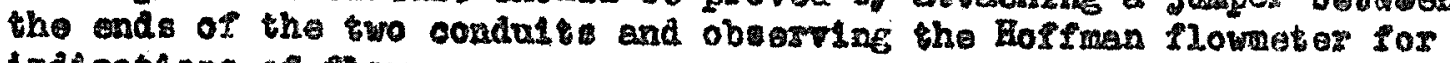
indleat 20 na of Iow.

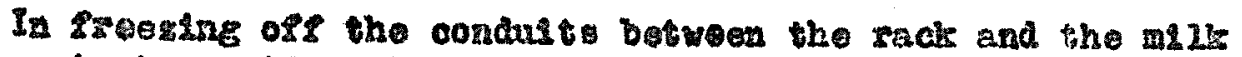
cen two lingortent constderestone should be kept in minds

(1) Water Rowling through one condats alght back up shrough the common drain into the toen jacket of the other milk can with

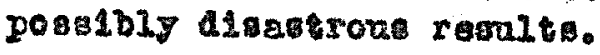

(2) Mol ature ull condente on the condests ranning down

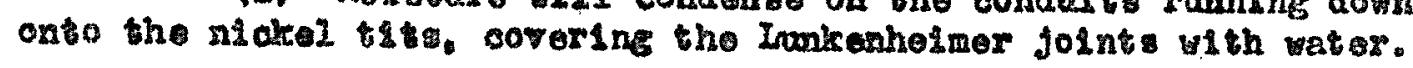

To arold both of the undealrable stuation, allow weter to Low through a condute only fust lons enough to froeze off. Then ohus of the weter. The material wil stay frozen. but the condust w11 warm ap to the polnt where no molstare wil condonge: furthermore, as thare Le ne 1 low of water, there w11 be no water preacturo ceuaing waser to back $x p$ the common drain Into the stoesn jacket of a milk can.

(o) A thermoneter phowld bo ctrepred by moang of erletion tape to one of the handies of the ils cen or inserted into a thermonet or vell.

\section{(3) Tranafor Roon Operatione}

Tho Ficit 9 mothod operation simplifies Transfer Room procedures as 14 requiras thet a scalo tank be ILIled with waterial only once before complete dopletion and emptying. At the atart of oach run. the tank to bo used on 8 elxcuit should be filled with 420 pounds of 85 resh meterial, of this approxtmatoly 70 pound w 121 be nsed in filling the mlik can, leavine 350 pound as the working weight of material. It is irmportant that fresh process flute of sero depletion bo asod. 


$$
12
$$

When the metarial in the mult can has bean broaght ap to par. the 350 pound in the veale tank is nearly $100 \%$ depleted and should bo sejeoted bofore otarting another nux.

Daring the fliling of the whik can a record of the welght should be made every minute. As coon as the weight he bocone constant. the Rack Foroman hould bo sotisled vithout delay.

Othormse from the above dotalls, the oporation of thy Trenafor floom does not differ from the urasi procoduro.

\section{(4) Pilling the Malk Can}

(a) Thas the bottom of the clrcuts and the rroozomort 0012 connected to the colum nearost to the soale tank ouch a Column I of Pletre 1. acal tank.

(b) Ireese the coll connectiod to coluan Iaxthese from tho

(c) Thaw the condust to the milk can, but keep tho Korotost valves closed.

(d) Tha the top of the ofreust

(0) When the top 1 complotoly thaved, creck the Reroteat. valfo which 1 o connected to tho colura nearest to tho milk dan.

(f) By means of the valve adunt the flow of material into tho can to as high a value as posalble withont pisohing. the clrcost.

(8) As won as flow atoy, quakly froome off the top of

(b) Open both Kerotest valres as far as possiblo.

(1) Hocord in tho Iog Book a dotalled deecription of the 12112ng procedura. tating whether or how long pltohlng has oocurred; also recoid the length of time the top and bottom hare been simalsaneousiy thamed, whether ang leak occurred, oto.

\section{(5) Stert of Operation}

When the allx can ha been 1211 ed from the sope of the columb. the average concentration of the destred component in the mill an w111 be greater than the coneeatration at the tope of the columi hence, the risst step hould bo to froese the top and to allow clrealetion to proced acrose the botton Jase as ooon as the mile can becones full. Clrcilation across the bottom thould continue for 24 hour before boginning the intarattont top and botton atroulation cycle. 


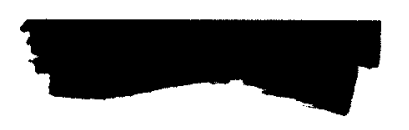

$$
5=13
$$

At the exd of this 24 hour perlod olrculetion ahould then bo started ceros: the top. but oare hould bo saken to take sanplet for as asy at the top ond of the arcult after about 15 mimutes, of drculation

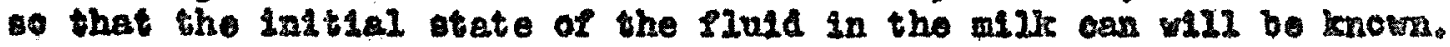

\section{(6) Hoptine Oparating Eroesduro}

At the prosent time Reck 9 is betng operated using the eutomat io camm timar mechantem to gite alsernats periods of top and botton elrculation. The cans are cot 80 as to give ronghly $55 \%$ of 4 howr ofrovlation at the top and $38 \%$ of 4 hours alreulatson at the botton. The optimum rat10 of the two has not yet been ceterninod bat tho laten rekvise seen to indicate that thit ratio is atisfactory. provided that the circulation rate is high enough.

The rate et which the dosired component, call it $x, 18$ transferred to the high prosonre milk oan copondo distoctiy on thre things:

(a) The rate at whioh $x$ 1s brough to the bottom of the colnam

(b) The rate at which the colume traneport $x$ to the tep.

(o) The rate at whoh $x$ is wathed out of the top inte tho ulik can.

It ean (b) Is a fanetion of the column cond1tion, and atsan conditlon. Iten (a) and (o) depond upon the rete of llow long the bottom and top of the columns and on the difference in concentration of tho materlal botwen the flros and last column in the nixculs. If this alfference is hish, the clrculation rate is $10 \%$ whis a moro rapld flow w11 lower the difference in concentrablon botwowa the Irat and. last colum in the olrcult. Thas, by doternining the difference in ooncentration of meterial betzeon these flrat and las

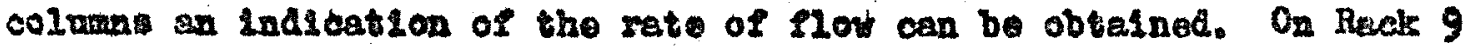
16 was found that two convector loop in the top and botton of each cirout were not enough to koep down the alforence in conceatration. so a thind convector loop in each alrout ves intselied. This holpod to reduce the difference in concentration from about 5 point 20 or 3.

When the difference In assay between the flrat and last columns bocome greater than 2 or 3. the elrculation rate hould be increased.

On Rack 9 atean bas been nged Ingtead of als to pargo tho water trom the treezenorf 1 ines in order that clrenlation ould be ogtablishod a raplaly as poeslble. Howerer, the stoan has a cooling affect on the intercolum connectore once olroulation has been ostablished (10werling the temperature from about $150^{\circ} \mathrm{C}$. $80120^{\circ} \mathrm{C}$. ). thue docreasing the rate of flov. 


\section{$-140$}

Por this rowon the Bask 9 arew has been in the hablt of turning oft the utean by mean of the togele witches an woon as the rharmopouple recerd inatoate a good chroulation. Tho toggle whteh mat bo turned on agaln before the beglanine of the noxt thawlng perlod. The une of than does not seen to offer enough adrantage to make lt vorthwhlle to install it on other racks.

Although the $B_{2}$ ak 9 aethod roquires lens work on the part of the crew members, it plscos on then a greater rosyonstbillty for continually watahine and malntalning the pertomance of the rack. It clrculetion stop or is deoreased for ary reacon, of 12 pltahing or infercolum comminioation occurs, not only will the colvmn not

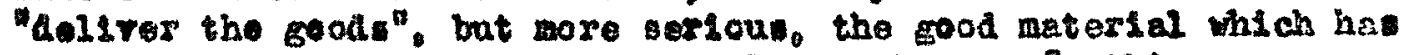
been solleoted in the milk can may becowe lost. In this war eoreral past days" produat and performanco may be rulned. in addition to the tine required to rebulid the colunn to a god condition.

The tine requit od under optluma conditione to build a milk can up to par, starting from voratioh is not yot known becanse of lack of wefielont information at this time Fowerer, an appex

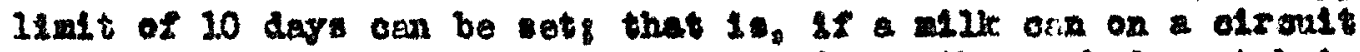
cannot be broweth up to pur orexy ten dare. the rack is not belne

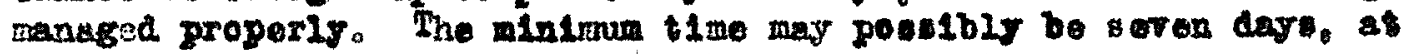
least eeron day 1 the goal ve hould shoot at. 10110\% 8

The dutles of the rarlou crew members on be dirlded as

\section{(a) Gontrol Boon Hen}

(1) Koep oonatent watoh of ganges and continuous reoorde.

(2) Keep epeolal watoh of thermooouple rooord to make cure that cireulation is proceoding eat sefector $11 y_{0}$ and that ofrcult are erozen on chedule.

(3) Roep watch of thermocoupl temperatuxe of thermo coupla attrohed so base of columa. Ths tempere ture indsases the conttancy of the stean conditions. If teagorature is arratio, the Raok Foreanan should be not1f1ed and stop taken to stab121s0 the condenuate leral.

\section{(b) Botton Rack Man}

(1) Ioop constant ratob of at eam condoneato lored ralre.

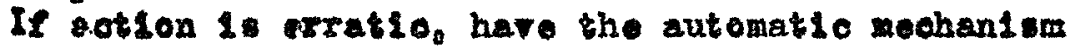
raduated by the inotrumant men.

(2) Reep vatoh of semperature on floweter to mak oure that good elreulation is malntalnod during the perlod for bottom olrculation. 


$$
5-15
$$

\section{(b) Bottor Beck Kan - Continned}

(3) Xoep wath of the freezomoff water during the porlod for the botton to be frosen orf.

(4) Iopp watch of the naterial frebeure gaugan to neke ouse that the pressure, espectelly during the reriod of top eirculat10x, is not dropping dangezousit elose to the pltohing lovel.

(5) Once per shife, during th top olreviation, readsage of the material preseure shouj, be made overy 30 cooonds over a 5 minute perlod in order to check tho contancy of operating conditlons. These readInge should be recorded Iis the Irog Book.

(6) A watah for material leak ahould bo malnsainod.

(7) Koep watch of duct and convector stean tompreturos and occaslonally cheok performance of contector and duos atean rape.

\section{(o) Wop Bagk Man}

(1) Watoh the temperature of the high pressure milk cen, It 18 wost important that this does not vary.

(2) Watoh and control the stoan prosure on the milk can.

(3) Make eure that the pop-off ralre 10 alwayg in good functionieg condition.

(4) Make oure that the stean trap to whlch the ailk can 1. attached is alwayg hot.

(5) Watch for material leaks (occanlonally leak ahould be tasted by using a Bunsen ILanol.

(6) Nalce sure that the condust to the milk can are alway hot, and whon neocssary to fxeeze then ofs. that no water becke np the comon drain into the stoan jacket of ther pot.

(7) Xoep a watch of temperatore on 110meter to make sure that good ofrculation is malntained during the pertod of top alrculation.

(8) Hoap watch of the ereezo-off vater during the pertod for the tep to be fromon off. 


\section{(7) Sampisng Sohadu] 온}

(a) Ous rog sample Irom onch and of each eiroult por 24 hours, botinning with the chird day of operaston on each run.

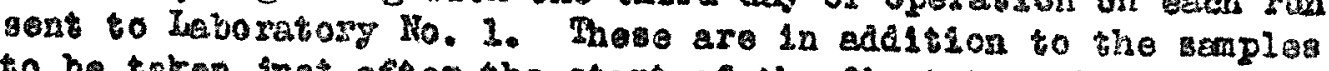
to be taken fnst after the tart of the flrat top circuletion
period.

(b) Any other opeclel aaniles send to Laboratory 10.2.

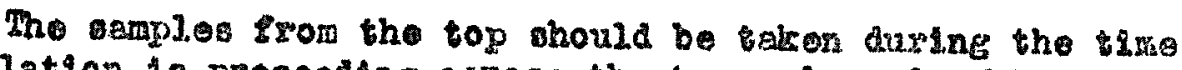
that clrculation 1 procoeding acrous the top and proserobly nest

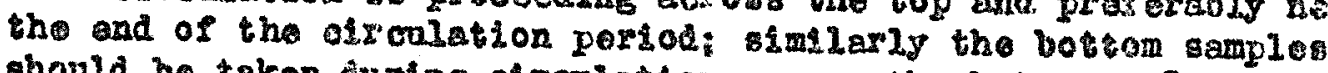
ohould bo taken turtag olroulation acroos the botbon. In this way It w12 be possiblo to ofeluate the arorago beherior of the colum and clrculatine eysten.

The groatest precaution thould be exerted to prowent a - material brait cusdng tho sampling porlod. particulariy when taking of andos.

To desple would bo moro zepresentative of the osrculation

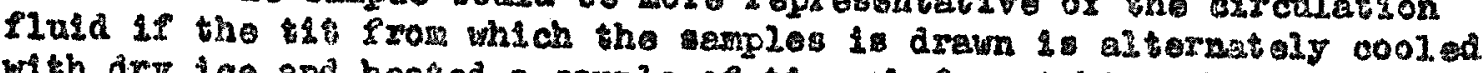

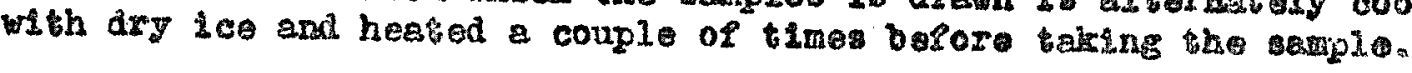

\section{(8) Ronoving ML Cys}

Tho of in the procodure of $r$ enoving the malk can ray be 218ted as 20210us:

(a) Fuezo art top of reak.

(b) D.oso Kerotoss valfor on milk can.

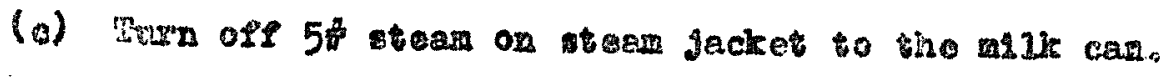

(d) Beoer condusts from rack to wilk een by turning strozo-ort ves or on condusto.

(a) After freezenofe water has coolad oodults to room tempera

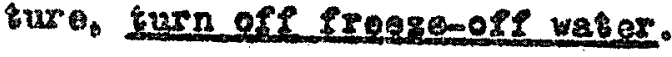

(1) With dyg 100 freeso oft 11nk 12 nes end adaptor botween

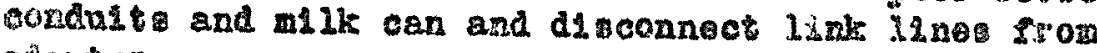
adeptar.

(G) Gap both 32nk 11 nos and adaptar.

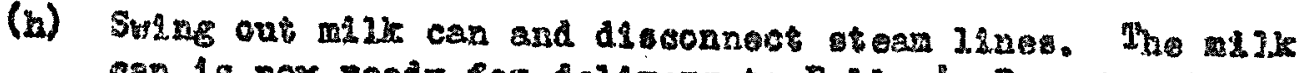

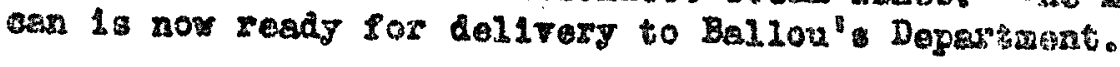


$E=17-$

(9) Some Do' ind Don to

(a) Unlese aboolutely nooessary, do not ahange the st san pressure on the jecket of the milk can or the temperature of the allik can under ans elrcumatances.

(b) If the temperature of tho mlll can must ohenged. chang it durine the top oireulation period with a conetsant waten on the material proseure in the column. Do not allow the meteridel pressax to fall below 1400 or to rlse abote 1700 p. 8.1 .

(c) In stillng the top milk can koop the top and bot 80 m circults thaved the minimare amount of time.

(d) Heke sure that the tare weight of an ampty mille can aro known before Installing the oan on the rack.

(0) Crew members should not turn eng Ireesenoss water or steam valtes wsthout notifylng the Rack Pormen who should oheck to - e that the correct valves are belng turned. A fou minutes opent cheeking an oporation of this kind mag save days spent trylag to rocoror logt ground. 


\section{Raok Cirouit Hscords}

\section{- Lestar Circuit Dlagrams}

\section{(1) Pursose of Diagrams}

Tho purpose of the diagrams is to provide all information persinent to the condition of the colums, convectors and condulta, the artangement of olroults and the disposition of instruneato on the rack for the use of the raok crew in an intelligent operation of the rack and to provide a perwenent rooord of rack ciroults and condition for management and the Teohnioal Division.

\section{(2) Prooedure in Use of Diagrams}

A now mater ofrouit diarram should be dram on the $0-8$ ahift on lionday and it w1ll be used as a guide for the raok cres during the following woek. At the end of the week the ohate will bo oollected and filed as a permant reoord.

The mater oiroult diagrame should oontain the following information:

(a) Condition of all colume in the rack indloated by the propor symbola.

(b) Condition of all conveotors in the raok inoluding inform ti on to those that have been oonditioned, those known to bo bad, those that have been used and subsequently taken out of servioe and those in use.

(a) Condition of all oondults, indicated by the propex symbols.

(d) Correot and oormlete oirouit diagram, showlag location of all instrunionta, conveotors, oondults and oolums in use and hook-up between them. The looation and type of product removal aquipment should also be hom.

These diagrams should be kept constantly correot by ohanging the oharts thenerer changes ocour on the raok. imenever a change is made on the diagram, a note of the chang; should also be wado in miting in the "notos" seotion of the chart, stating briefly the chango rade, together with the dato and time. 
Changes of raok ciroults from one storage tank to another should also be noted in the same place.

This information, and nothing else, should be containad on the mastier ofrouit diagrams.

b. Raok Performanoe Reoord (Automatio Uilker Hothod of Opiration)

\section{(1) Purpose of Record}

To provide raok orews, management, and the Technical Division with information aonoerning operation of the raok uaed in determining the efficienoy of raok operation, rate at hion product may be removed, and all other information of intereat in daily control of operation on the raok.

\section{(a) Prooodure in Dse of Rooord}

This record when completely filled out provides an adequate daily reoord of the raok performance. On the left odge of the reoord a $t$ imo soa lo is provided, and all entries on the record should bo related to this time $80 a 10$. For eac.. oirouit on the rack a seotion of four colums is provided and in these oolume the following information should be reoorded:

\section{(a) Lisileingg}

In the first oolum all aotual milkings from the ofrouit in question should be entared. If tho milkings are mado with the regular automatio milking arrangement, the milking is indioatod by the letter "f" with an exponential number to indicate the number of milkings that have been transferred into the lo. 120 apsule. For exampio, $\mathbf{z}^{\mathrm{J}}$ ind icates that three milkinge through the small No. 23 or No. 31 capsulo have transforred into the larger oontainer. If the nilkings are mado manual ly into a small capsulo, thy should bo indioated by the letter "2u" also but with no exponential number and with a note is to the oapsulo number coompanying the "H". When sahoduled milkings are missed for any roas on this should also bo indloated by the proper symbol -- "p" for pitohing "O" for operational diffioultios, "C"for laok of ofroulation, "In for interoolum ciroulation, or " $X$ " for low as say. 
The time at which the large No, 120 capaule it removed from the oirouit, and the number of the oapsule should be noted in tis is oolumn and when raok samples are taken they should also be entered here, with the semple number and 001 um number inoluded.

\section{(b) Produot Control Supervisor:}

The secand colum is for the product control supervisors. Here they will enter their instruotions conoerning milkings. This is the only oolum on the reoord whioh is not the responsibility of the raok rooords man.

(o) Hours of Ciroulation

In the fourth ool um space is provided for the reporting of rack difficulties, such as pitohing, intercolum oirculation, or 108sed. When pitohing or intercolum oirculation ocour, their duratico should be indicated, and in the case of pitahing, the violenoe as show by the maximum overboard water flow during the ponk of the pitching, and the oolume involred, should also be shown. When 108808 oocur, the weight lost and the looation of the loss hould be shown. All salvage drawn off in oupsules, and all produot other than that obtalned by regular milkinge, suoh as oxpules removed from the top of the raok in plug-hunting, should be entered in this oolum. Finally, all stora chamber ohanges should be shown here.

At the top of the page, apaoo is provided for the reporting of the storage chamber in use and the number of oolume in operution in oach oircuit.

Aoross the bottom of the report, space is provided for the signatures on the raok foremen on ea oh of the three shifts, indicating thut thoy have oho clad the reoord and have found it to be oorreot.

This roport is mado in duplicate. The original is sent to the plant rocords office for use in daily caloulations for control purposea. The oopy is kept by the produot oontrol suporvisors for their use in making deois jons on product removal, and for the referenoe of the reohniosl superintendents. 


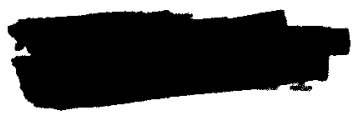

0. Opeiating Recorda (Ra ok 9 systom)

\section{(1) Furpose of Record}

To provide a dally roport of procrese and porformanch on racks operating by the Raok 9 eys tem of top oiroulatica to bo used by managent, the Tochnioal Division and Operations.

Each dally form will provide a reoord of the operation of one raok. It 18 divided into two seotions headed "frout" and "book". "Front" rofers to the low numbered side of the rack or column 1-61 while the "back" refere to colume 52-102. Therefore the reoord will provide data on two high pressure pots.

At the top of each colum headed "front" or "brok" is a seotion for data on storare chamber in use, the high pressure pot number, oirouit numbers and total number of colume in service on the side of the reck in question. This information should bo fillod in daily so that any ohanges will be apparent.

The same arrangement concerning the circulation bar that is now in use on the oyole ohart hes been utilired in this reoprd. However, instead of marking top and bottorn oirculation in color to differentiate between them, it is asked thet top olroulation be marked by ahading with diagonal lines, and bottom olroulation be ahow by flling in with solid biaok.

On oach side of the ciroulation bas is provided spaco for reoording incidents of rack operation. All samples should be reported, giving the sample number and the looation from whioh the sarple was taken. Losses should be indioated showing the weight lost and the place from which the los ocourred. Pitching and interoolum ol roulation, when they ocour, should be show, together with the length of time inrolved, and, in the onse of pitohing, the violonos hould be indioated by the note "Ilght". "moderate", or "violent" or any other note wioh the recorde man may prefor.

At the bottom of the page is provided space for a daily total of ciroulation hours. Top ofroulation hours should be recorded on the top ine and bottom oirculation on the bottom ine. The oyole total of oiroulating hourg should aleo be carriod in the spaco provided. 
The "percent ocimlotion" speoe r sed not be filled is by the raok orevs, but will be flllod in by the product control sup arvisors on the coples they reoedve. The "days eince pot ohange" should be filled in howevel, by the rooords nond ind loating the total days elapsed... whether operating not-minge the la st: produot was removed.

Space is provi ed the botton of the page fior the signatures of the foremen on the three sinifts.

The record should be made with two oarbon copies. The original will be kept by the raok olew as their ravord of the proeress of the oycles The tro on rbone villl be delivered to the plant of rice st, 2400 each day, as are the other milking records. One oopy will be kept there for the information of the Teohnioal Superintendenta. The other will be sent to the plant reoor ds office, after the "peroert oompletion" item has been entered by the product sontrol supervisors.

\section{I'ransfor loom Rooords}

a. Deily Operating Summery

\section{(1) Purpose of Summary}

To provide information concerning torage ohamber we ight-pressure-temperature relationships, and material trensfers in and out of storage otambers used in keoping material balanoes on the plant.

\section{(2) Prooedure}

\section{(a) Operating Summa ry}

Required in the "operatines sumary" seotion of the report is a set of readings, taken at the begirming ond and of each eight hour shift, of steam pressure, meterial pressure and atorage ohimber woights. A fourth oolum is provided in wh the difference between the initial woight and final woight is recorded, with the proper sign to show an jacrease or a deorease. To the right of this oolum a spaos is provided in which the reason for the ohange in atorage ohamber weicht should be noted. If it is "yormal" in view of product renoval and operating ocoditions on the raok this oan be so indicatod. If weight differonoes oxist Whioh a ro not explainable in this may the operator should inform his foreman of the difference and try to acoount for it in some way. 
In addition, on the right adge of the sheot a column is provided for rokdingo every four hours on condeneate temperatures on each of the drain 1 ines f: cm the 10ippound stoam traps on the storace ohambers. Theae temperature readings provide o chock against bad traps or open bypess valves whioh oan reault in serious loss of steam. High temporature readings should be the signal for a oreok-up on traps and by-passea.

\section{(b) Transfor Summary}

In the transfer summary section of this report 911 moterial transfer should be roported. This inoluded all transfors of new matorial into storage chambers, and ali transfers of depleted materiel out of thern. Exast irifornation as to woights involved and so:aial numbrirs and storage chember nunbers of the cylindars used in required in every oase. The operator who oomiletes a transfer is responsible for seeing thet it is entered on tire shost.

\section{b. Treasier Room Charts}

These 18.reg oharts are used as half-hourly cheok of operating conditions in the transfer rooms. They are primarliy for the use of the transfer room orew, but are colleoted and inspected poxiodioally: It is partioularly inportent that transfor room nan roalize that the stoam pressure- materlal pressure- solo weight relationship provides a oross oheck on any one of the factors inm volved. For instano, it is possible to obtain a fuirly acourate woight if the steam prossure and material pressure are known-m I1kewise only ane material pressure corresponds to a given storage ohamber woight and stoam proseure。 By using this reletionship the acouraoy of all the messuring instrumoets in the transfer room can be oheoked, and inacourate gauges of faulty soalas ay be disoovered end correoted.

\section{Materia] Transfor Work Shoets}

Those forms provide a wa of keeping working information on materiel transfors, and are for the uso of the transfer room orows. Readings should be taken every fifteon winutes during tho progress of the transfer in order to keep a careful ohook of material passing over. Aftor transfer has boen ocmpleted and the sheote sre used they should be flled in manila folders in the ocotrol roan filea for us as a chook by foremon and transfer room nen. 
3. $\quad$ Log $300 \mathrm{~kg}$

a. iraok Log Books

Thes log books aro inte adod for use es supplemeats to the other rack reoords. Any essantial date for oper'stions should be iroludes on the pereformance records but all supilemental.

informtion wa to teohnique omployed or suggeations for furcher work shous.d be inoluder in coteil in this brok. Somo of the bocks salso inolude colum reoords, ma intenanos seoords, waterial balanow on the trar sfer tanke and any other information wiloh the ahier rask forman dasires. These booka are essantial for incormation to bo passed from one ahift to anothar and aro not oonsidered as having any formal value exapt in the oourdination of the work baing done on given rack. ilake oertain that all statomonts made in the book aro signed by the one making the atatement or the porson giviog the order.

b. Trang fer koora Log Booka

These 10 books are also primarily intended for the information anc oorrelation of work belng done in the transfor rooms. They usually contain informstion rerarding tho weighte of transered matorial inoluding starting and final woights by shists. Thay may oontain information about mainteranga work. which is needed of done or other portinent facts about the operation of the transfor room. Ilere, as in the other log books: should likews so a sgod statement as to what hes beon done on each shift. Proper headings, inoluding the dete, shift orom, rack foreman: oto., should be used for each shift's entry in thes book.

\section{Sunerintandants and Assiatants Log Books}

Thase ara sumarizing books of the oparatica on a given shift. They include dete and information on the plart as a wholo as, fo: axample, the stote of tho stean supsy, or the oxder of racrs starting up and shutting down. This incer on 1938 cumiariaos the information oarried on the wall ahat for a given shift conoerning oirculation, miliking and generel plant or secticis parformanoo.

\section{Summag}

In fererel, the system for keepling operational reoosde my be aunawsed as falling into four me in parts. 
Cirsuit and raok condition information is kept on the mator rack onarts. Daily performance information is obtained from bro sources, the performanos reoord referring to rack oparation, and the transfor roon operating sumary referring to transfer roon information. Dofalied information for the tranamitial or speoific informetion from one or ew to the next is providad by the $10 \mathrm{~g}$ booles. MII are neoossary to obtain oomplete ploture of plent performana, and every effort ohould bo mado to malso 11 nooossary entrien, and male them oomploto and oor reut. 


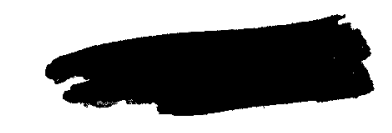

Section G. Flant Baergoncy Instruoticng

\section{Control Derlces.}

\section{a. Temperatare Controller.}

Tho varloug gatges and control derloes loceted in the control room are ammarized in Seotion C. Fart 10. Another verg Important device which 28 essential to the operation of the rack and whion is rexy Indicative of the way in which the rack is operating is the veter temperature recorder loosted on the meganine level out ide the trangfer room. This is a dual purposo instrument in that it not only records the temyerature of the water going into the rack and the tenperature of the weter going out of the rack bat also is f1tted wth a controller device which operates the make-np water valve to allow moxe water to onter if the temperature riaes and ohut of of the water if the temperaturos 20wers. Thi glve important information a) regarde the conditione in the rack. There hould bo about 10 degrees I. difference botween the in going and outgolng water. If ther 1: appreclably moxe than that then there is probably pitching in the columns. The derice 18 alvo a cood indlcator a to other conditions that nay be exlsting on the rack. The axact ues that wan be made of the instrument in given in the neat part of this gection.

\section{b. Condengate level control.}

Th1. 1. a derlce located on the botton of the rack which wile not in the province of the Operatione Dopartment to adjut or 80 oontrol hould be mado famlilar to every operetor. Irimarliy conel sting of a sight glase and alr controlled valvo the device maintains the proper level of condenaate in the rack in order to keop constant oteam conditione in the reck. The quality of the steam and the nature of the atean condit10a. in the reck markediy affect the temperature of the hot wall in the column so 1 it 18 rery important to have the proper control on this factor. It $1 \mathrm{~g}$ not perticulariy eigniflcant exactly where the condencate level is kept but the lerel should remain as conetent as it is possible for 1 to be.

Fertloular ware should be exereled if the condengate level control akould cease to operate properly and allow the condensate to build up in the rack. Phis in iteelf 1 of no particular importance but 16 is rery important that the veter level bo lowered very -louly. When the watar level rose, the column cooled oft to some extent and pulled materlal orer from tho tank. When the water level drop: the material must of coures be returned to the tenk. This must bo done through tho condutts $s 0$ if tho lines are not large enough to ecoomodate the explux of materlal, the pressure will sise quito abnormally. The operater should watoh the meterial pressure gauges olosely wen the condensate level is being controlled by hand or when the Instrument Department is adjugting the controllex. 


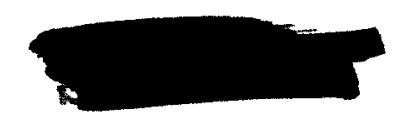

$$
0-2
$$

\section{c. Stean Hounetrer.}

This derice has boen installed on sererel of the racks and probably w112 be installed throughout the plant. It is a triple marking recorder keeplng a record of stean flow in pounds per hour. team temcerature and ateam resure. This 18 located on top of the rack and the operatore should be lastructed whe the ralues ohould be and to report anj abnormalltes.

\section{Gassifled Aocording to Brpe of Pallure}

a. Material Bloveofs Stress Ilnaing correot location of leak.

\section{(3) Elng Bloun Out of Colum 3at}

(a) Attempt to isolate column by turning on Intercolumn conneetor Ireesenfe water on both top and bottom

(b) Turn on Duct Ian (see Dote 2). (a) If the flowing water has not oucceeded in freezine
off the intercolum connectors adjacent to the colunns with the break (seo lloto 3), attem to froez off the intercolumn connectors with dry $1 \mathrm{ce}$

(a) Try to thop or retard flow ueing Hoberts ${ }^{\circ}$ Wooden Block. ILIP emergenay jlug or dry loe block.

(e) Try to freeze off tit with ary ice. (see note 4)

(f) Try to cap orf with Lunkenholmox eap.

(E) Zor a blownt of an intercolum connector. try to retard flow by Finching the 18nk 11ne lmmediately beck of the Inonkenhelmer with palr of pll ore (wee Hoto 5). Aftor flow ribtarded, at tompt to freese Jfe wh dry 1 the and cay ost.

(b) For a bad leak around a Irunkenhesmer connectson whloh oannot be etopped by tightealing the connection or by exeezing off with dry 1ce; a wat rag placed around the Iankeahoimer may sometimes otop the plow by formation of solid hydrols sed material.

(1) If the abore method have not stopped the flor rithin a minute or two, turn the stean off the ooluan alosing both top ctoam ralve and bottom coadensate ralre on the column. 


$$
6-3=
$$

Lory affort should be made to avoid an aceident 11ke a material break by alway having at least one porsen a a helper to hold the dry 160 and by Ireezing off according 1.0 the approved methods described in Hote 4.

\section{(2) Ilnk Llne Braak}

(a) Durn on water on intercolumn connectors, freeze off colis. and atorage tank t1ts.

(b) ingra on duct fan.

(c) Fineh off link line with pliers 30 an to retard flow.

(a) Attengt to froeze off Iink Iine.

(3) Trangter Booz Broak

(a) Close duct doox.

(b) Tarn on duct Ian and open damper (puil chain).

(c) Turn on cealo sank t1t froeze-off vater.

(d) Jurn on wall tan.

(e) Turn osf hich frosirare iteam.

(s) Mood tank jacket with water.

(8) Trooze off rack.

b. Iov Egenero Alr Paslura

(1) Graptong

(a) Drop in circulating vater temperature.

(b) Increase in overboard water flow a indicated on chart in Control Room.

(c) Now of vater over root.

(2) Sierancy Frocedore

(a) If the alr fallure is noted before the water temperature has fallen belon 13007.. operate the gate ralre by hexd as directed by overboard water chart in Control hoon unill alr pressure is restored and automatic flow regulation io establiched. 
$-4$

(b) If the temerature has dropfed below 130\% In the rack have probably cooled off to the polnt where thor have geined material. In this cave the temperature of the elreulet1ng water enet bo bropigt back elows and ceresully to 1te normal operatine ralue. Int whould bo dono by lowerline the tearerature control an far as 1 will go and then gradtalit raising it.

c. Hien Erocoure Alr Malinr

(1) Sxptome

(c) Fall in alr prougure gauges on oteain board in Pransfer

(b) Iall in stean prenmure on Scale Tanks.

(c) Dall in material prosoure in Scale Manke and on racks.

(d) ilsoulng on radrs.

(e) Gain in volghts of Soale Tanks.

(2) Emercuan Exondure

(a) Ireeze-ast racks at Ireeze-ort oo11.

(b) Iroese-ort sealo Tank tits.

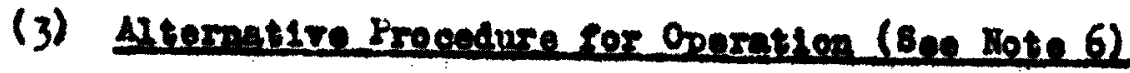

(a) Gose valtes on both sides of Fonter Ifeducting Valve.

(b) Cose valve leading from by-pase to Joster valvo bonnet so that one olde of the Joster reduclne valve diafhrage ill not hare a thousand pound steam pressure on ono 140 of It and ne alr prescure on the other slde.

(d) Opea ralve leading to stean proserure gange.

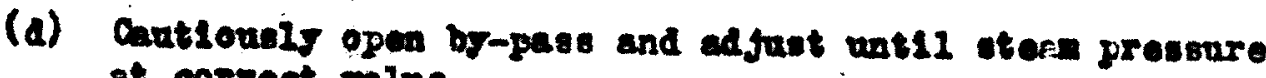
at correct palne.

\section{A. Bth Erenmo Stean Bathre}

(1) Snptome

(a) Iose in volpht of atorage tanks.

(b) Drop in material presenre on rack.

(a) Drop In teml exature of elreulating water

(d) Drop in realing of gtgan prosenre ganges at tor 


$$
0-5
$$

of raok in case these cangen cal ot thore.

(d) Hich preawere steam ganges in trancfer and control zooms mav also drop in cose of a ceneral stean fallure.

\section{Ixercener bronenre}

(a) Treeze off recke all aleng bottom and top.

(b) Treese oxs ond co11.

(a) Irease ofs 8268 on storege tank.

- Enomatine Wher revime

1. Elpens

(a) stoprece of olroulating water pupe.

(b) Rse in terperature of elronlating veter.

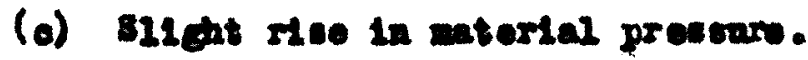

\section{Earrang Brooture}

(a) Treese off botsen and top of reck and at and colls.

(b) Surn off hich preevere otean.

(c) Apothar ready is to conneet in another vater elroulating Pun.

Noteas

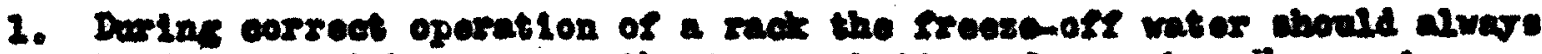

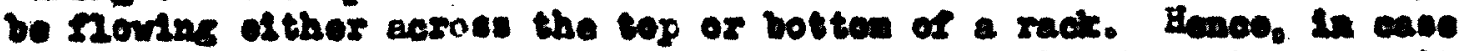
of a blowers it abould be neocesent to turn on only the vater elroults on ather the sop or the bottem wich are aot already an.

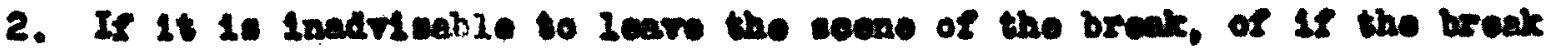

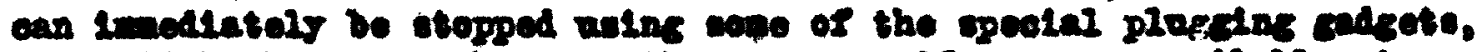
It vould be botter to have another pereon. Is ans are aviliable. tarn on the duot fan. Utualls hea a week ocours, the cloud of anoke qudeth attrecte to tho soste of the aceldent a mener of oparatora tho are andeas to holp. 


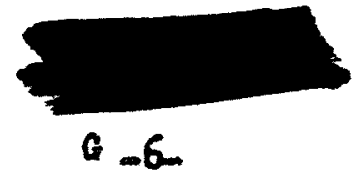

3. Sometives the flow of the oscaplng procese Ruld is so rapld that it camnot be cool od down quidelJ wough to colldify. The Intercolvm connectors ahould be felt with the fingerw in order to 100 whether the process fiuld has beon froren oft or not. In fact it is alvare advieable to foel with the Pinger an I1nk 11ne, Int ercolom connectors or tit that 1s thought to be frozen off before asmulng that the process fivid really has solldifled.

4. There 1s a opeelel teohnique for freexlng off t1ts wh dxy 1ce, both

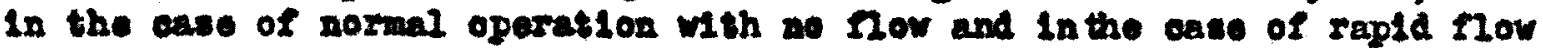
rosulting from matertal brcak. For a sormal Iroeze-off operatlon, hold With gloves on a plece of dry 100 firmil egalnut the tlt about two inches

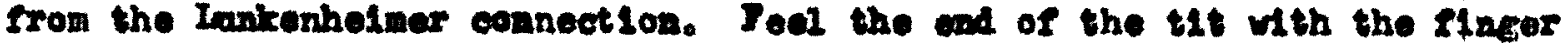
and as the Ilckel becomes cool alowh wore the dry 200 toverd the colven

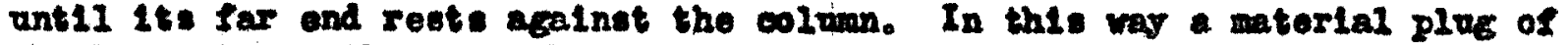
the longeet poselble length can be propered, a plug which will nover blow out if the dry 2ce is alway held firmiy on the t1t againgt the column.

5. Mans operators carry with them larce pller: with part of the wire cuttlac adger purposely drilled so that the edges will plinoh a 11 nk 1 ine together, bat not out throuch the 21nk 1ino.

6. It Is not reconnended that seale tanks be operated on the by-pase except In cases where the ralre aystem in moch that the steam connoction to the Foster ral ve bonnet oan be olosod wille at the wase time kept open to the

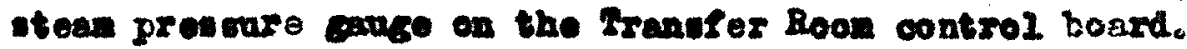




$$
\theta-7
$$

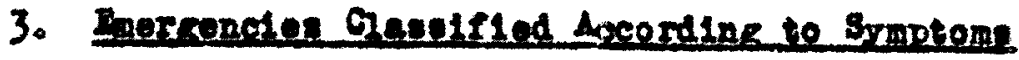

What to Greck to IInd

\section{Sreptone}

Drop in Orroulating water Touperature (Control Boom Bazeer).

R1se In ofrculating vater temperature (Control Roon Buzzer).

Drop in high preature alx
gauge.

Drop in Transfer Room it van gango

Drop in Control Boom high pressure stean ganges

Orerboard vater Increase

(water over roof).

Orerboerd water decreames

Drop in low freseure alr (Control room baseer). roentbre Care

Lox Freeware Alr Fallure

Cauce of Diffleultr

Check alr wapply gauge of clreulating water moter.

High proscure etean Iallure.

Chook steem gange on control roon board.

Hitchlng on sack.

Check rack sor pitching Stop as soon as possible

Frumpe stopped

Cheok 11ehts on purup control boexds.

General fower Faflure

Check other pumps

Compreesor fallure

Check compreseor

Broken diaphrage on Poster Ohook all Poster Talve Valve. bowls for leake.

Mranafer Roon header off

Check in other Pranefer Foome and Control Room high pressure stean gevs to we wether 8 tean fallure 1s general or Ilented.

Ceneral Stesm Tallure. Gock other ganges and with oterm department.

ILtohing on rack.

Oreek for pitching.

Iow presenre alr felio ure.

Cheok alr rupply gauge on circulatins water wot

fond fallure

Check olrealating water temperature and papps.

Compressor atr fallwre

Check other rack alr Eaver.

Storpace of atr apply to one rack
Check valves to corres ponding rack. 
0.8

What to Grock to Ind

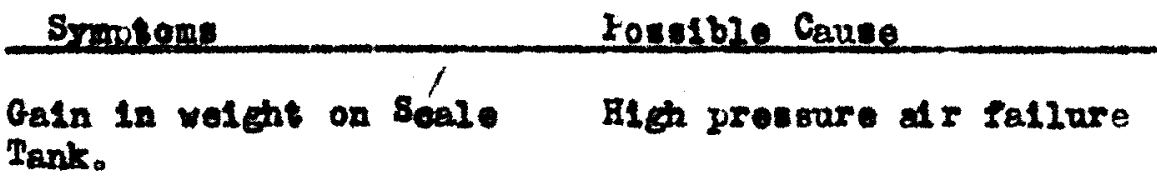

Cance of Diffloultr

Moek hich prestrure alr gavge on Tranter floom board.

Low: in weight on Scele Ireak on rack.

Check for external leaks. Tank. Ohock Internal leake by freezing off elroults and deternining if lous oontinum 9a.

Lows in welcht on Scale Tank

Fallure of Poster valve. Chock ganges on at. $r$ and stean 12nes.

Increase in waterial fressure.

"Creoping" or Tonter relves.

Chect ganges

Tallure of Poster relres.

Chock alr and stecm gauges.

Decrease in material proesare.

Inece in aroted.

Ireese off and cheok for leaks.

Steam fallare

Creck steam gauger.

Bleh prouture alr fallure Cheot alr enuges. - $\quad *$

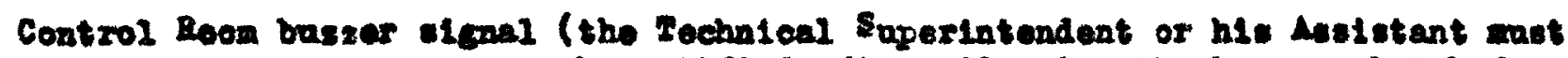
be notifled after ellencing the buserer, bat before the drop is replaced.

Back basser panel

1. Three phese pover zallure.

Check solmoids for Iroest off noter.

2. Lowes manifola presture low.

Chect prongs.

3. Top manifold abore $175^{\circ} \mathrm{s}$.

Qheok clrealating vater controller.

4. Lower manifold below temperature.

Cheok elroralating water controller.

5. Furge alr presenre below $70 \%$

Chock for low prosture alr fallure. 


$$
0
$$

What to Check to Tha

Srotions Cane of Defientit

Conter busecr panel

2. Nake-up vatos pressare 200

Crock with st gam doparteent.

2. Ireose off vatar low

3. Irocene Steen fallure.

Chock top boder for anply.

Chock inth otern departrient.

4. Intimot tone for Emlornen eroond to Hatertal

Material on Irritate the ores, tho bronchial tubes and lnnge and to lese extent the sidn. Hoverex, if the inetructione fron below are followed jon vill not be infared by contact with the meterlal.

a. Genersil

(1) If jou have boon vorting in an area in which material has loaked but hove no pain and do not feel 121, no treatment 1s required:

(2) If you get onough naterial on jour clothins that fow clothing look: dusty. Jou will take a shower lomediately and change to a clean oult of coveralls. b. Ire Iningies

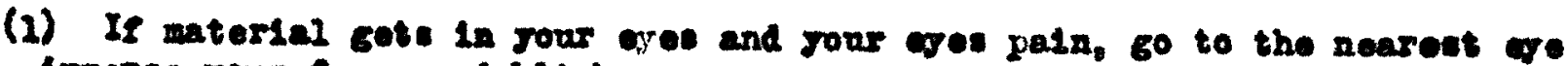

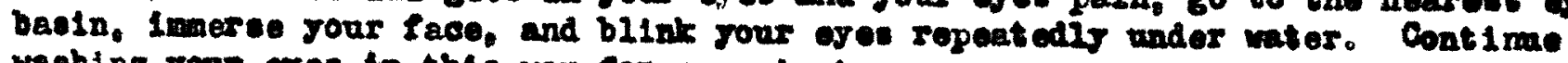
washing your we in this way for one minute.

(2) After rou fintih waking the eyes requert to the maree at once.

(3). If the pain to rellered by the washlng, repart to the marse when cossonsent, In no invtance lator than the ond of the ohlft.

(4) If the pein is rellered by washing. but cones back later, report to the auree when contenlent.

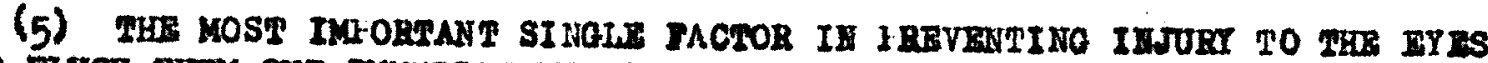

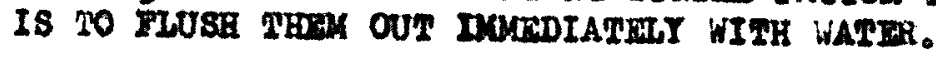

\section{c. Burns of the ekin}

(1) If the material gets on jour akin, but no pain is folt wah jour akin with plain cool wator (do not use soep) at your convenience. Washing 18 to be cont imued for one alnute. Feporting to the muree to not required.

(2) If material gets on the okin and the ekin hurts. ef ther at the time the material got on or latex. Inoh or soak the pathelal area in cool water for five mimite and report to the narse. 


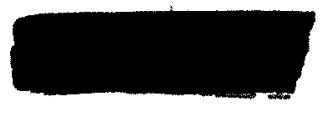

$0-10$

(3) If material gote on the akin, and pain derelope after you leere work. soak the falnful area in cool water for two bours. If the paln has been relleved by coaking. report to the marse at the start of rour next shift.

\section{d. Inhain Hateries}

(1) If you happen to breathe material but have no pain arterward report to the nurse when contentent. but in no case later then the end of the oblit.

(2) If rou happen to breathe material and aftemard have jain in the nose anci throet, pain in the chent, couching, shortness of breath, retching or romlting, report to the nurse at once. 


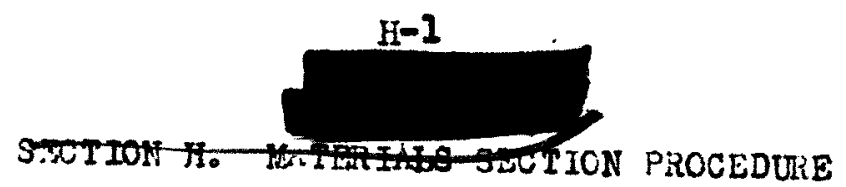

\section{Conditioning Prooedures}

As stated in the seation on physical propertios one of the most important aspeots of the plant operation is that of proparing equipment for use in the plent. It rust be ontirely free from all water, organio materials, dust and anything with whioh the matorial might resat. The faterials Seotion is primarily interested in two phases of this problem. One is to oondition the equipment for use in the plant and the othor is to empty the produot or depleted material and reocndition the equipment so it oan be used again.

a. Conditioning Niokel Tubing

(1) Tubing is first dorreased by running oarbon tetrachloride through it.

(2) The tubing is then blom dry with oompressed dry nitrogen.

(3) The nest stop is to heat the line while evacuating to drive off all the moisture. The tubing is apped off at one ond and the other is attached to the oonditioning manifold. The evocuation is then started meing certain that all of the joints aro tight. The tubing is then heated from the cappod and toward tho manifold until the entire tube has been heated and is dry.

(4) Shut off the valve to the vaouum pump.

(5) Allow eresh ais to pass into the tube while atill under vacuum. Make certein, however, that none of the frosh air is allowed to pass into tho vaouum purm line as it is very reactive with the oll in the purp and will oasily ruin a pump if the slightest traco is allowed to onter the pump.

(6) Turn the fresh air off and bleed the aonditioned manifold down to zero gauge pressure.

(7) Detroh the tubing from manifold und oap-the end boing sureful not to screw the oap any tighter then nosessary to obta in good soal. This avoids misshaping tho ferrule on the tubing.

The tubinf has them been docroased, blow dry, evacuated, hoated dry and charged with fresh air and is then roady for use with process material.

b. Reconditioning Equipment

Used tubing and equipment containing process material can be reconditioned in two ways:

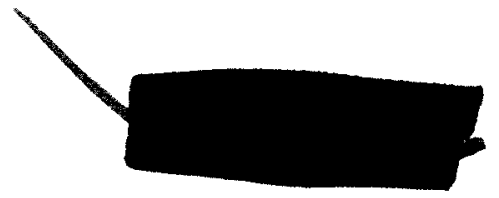


(1) Rapid Reoonditioning Wethod

For immediate reoonditioning small equipment is flamed out in a hood. This is done by starting at one open and and heating, with a burner and driving out the process material. This is always done by heating from the open end to the olosed end rradually.

After the tube is empty, blow out with dry nitrogen. Connot tubing to a souroe of fresh air and run the fresh air through the tube. The tube is then oappod off on both onds and the tube is ready for use. The mothod is only used in an emergenoy when tubing is needed for imediate use.

(2) Standard Reoondition ing Procedure

The mothod used whorever timo will permit is to uncap both onds and immerse the whole tubing in the hot water oloanine bath. The heat of the bath will drive off all material whioh will bo disoolved in the water. The tubing will be washod oloan wi thout any trace of material boing left. Circulating water in the bath has boen found to give the best results. The method is very rapid and tubing should not be kept in the bath any longer than nocossary. The tubing is then treated as new and ia conditioned in the same mannor as other now tubing.

- Conditioning Gauger

The procodures for conditioning gauger has been someThat inadequa to in the jast. A groat deal of shoddy work has been carried on boon 280 of laok of material and lack of time to do proper work. It cannot be omphasized too greatly that time saved by improper conditioning is a falso cocnomy. The gauges partioularly must be oonditioned exactly an outlined below since it is essential that the exaot conditions of pressure on the rack and in the transfer tanks must bo lon at all times.

\section{(1) Conditioning Hew Gauger}

(a) Remove the cap nut on the ond of the Bourdon tube, It is a soft solder and oan be dono satisfactorily without harming the gauge。 
(b) Fill a pressure tank with aarbon tetrachloride and foroe a stream of solvent through the Bourdon tule allowing the solvent to pass through until tho solvent is olear.

(o) Dry by passinc compressod air throurh the tubo.

(d) Pass a stream of fresh air through the tube.

(e) Roplace the nut on tho end of the tube.

(1) Attach the cauce to the voouun pump, while heating. rertly and pass in fresh air again.

(G) Reassemble the gauge and calibrate with nitroren; leuve cappod with nitroron.

\section{Reoonditioning Gauges}

(a) Dismantle gauge keoping indicator moohanism with the tube. If the gauge is not numbered, it should be numbered and a file ard should be made out for it in order to keop an acourate record of each gauge.

(b) Place tube in oil bath and drive off all of the material.

(o) If the material is driven out completely the gauge may be fresh aired assembled and put baok into servioe. If the material is not driven out oompletely then the gauge must be dismantlod still further by taking the Bourdon tube out of the sooket.

(d) The plupged material should then be drilled out if posaible. This treatment is necessary partioularly when organio material has been left in the tube. In very diffloult oases soking for some time in ammonium oxalate solution will help to loosen up the material. If the material does not come out after rigorous troatment the plupged part of the gauge must be disesrded. After the tube has been cleaned out the oap nut should be removed if it has not al ready been dotached and ter passed through until the water is olear.

(e) Put the tube inside the gauge oase and attach a 10" jumer which has been degreased.

(f) Have the tube and jumper heated wils passing nitrogen through the tube. Be careful to heat the tube only in the center and not a rigorous hoating at any time. Do not apply heat to the ends of the tubs where they heve been soldered. 
(g) Assemble the gauge and oalibrate with nitiogen.

(h) After the gaure has beon oalibrated record on its flling oard the date, and prooess used in conditioning and the rame of the person handling the gauge.

(i) Evacuato the gauge and oharge with oither nitrogen or fresh ix. Cap off and the gauge is ocnditioned ready fer oporation to use.

\section{Plugged Gaugea}

(a) Plugged tit

1. Place a length of steol welding rod into the eleotrio drill and bore out the material.

2. If a hand plug is not removed by the above operation or if one forms at the weld, the tit must be out off baok of the wold and drilled out with the welding rod as drill.

3. If the gauge has a $1 / 8^{n}$ njokel tubing inside the tit joining it to the gauge, this should be removed by nelting the silver solder.

4. Counterbore the stem with a $5 / 16^{n}$ drill before ailver goldering.

(b) Plugged tube

A tube whioh cannot be oleaned of saterial is uovally plugged where it foins the stem.

1. Heat the nut on tho end of the tube with a flame. Do not apply the burner to the tube but only to the nut. Care is essential in this operation.

2. Heat the stem and fuse the solder at that seal and uscrew the tube. Do not apply heat to the tube. Tapping the tube is more offective in breaking it loose than is applying pressure.

3. Cloan the tube in hot water removing all traces of material.

4. Cloan the stem in hot water making sure all material is cleaned from passages.

6. Buff all surfaces which a re to be soldered with a wire brush. 

6. issemble the tube into the stem. The tube must Pit tirhtly; if not the tube is probably not in the exaot position.

7. Screw the oap nut on following the same instruotions as for the socket.

8. The tube should then be soft soldered and tested under nitroren pressure.

9. The gauge is then assembled, calibrated and conditioned for use in the plant with evacuation, gentlo hoating, and fresh eir.

2. Haterial Transfor

\section{Goneral Instruotiona}

Matcrial somes in from the plant in quantitios from 1 ownos to 70 pounda. All this material must bo transferred into suitable containers for shipment or storage. The oontainor into whioh material is being trunsferred will a lways be kept cold with either oiroulating, water or dry ioe. The container from which the material is beine transforred will be prehoated until it reaches the liquid stage. In all casos, material transfor will be anried out by pouring the liquid material whioh mans that the container being omptied will el be held above the recelving oontainer.

\section{A. Emptying Capsules}

After making sure that all fittings are tight, plaoe the cansule in a hot pater bath for praheating. Indioation that the Ilquid tage has been reiched will be found by ipping the oupsule from one side to the other and feoling the liquid moving inside the oapsule. Froezing off the stem at least two in ahes in back of the fitting, remove the right anglo container.

Shipping oontainers are kept in a pot of dry ice slush wilioh is a rixture of dry ioe and oarbon tetrachioride.

Larger containers cooled with oirculating water. Harm the valve on the container with a bumer and then open ito of the ospsule the valve, heat the material lines to the end necessary to continue heating and heating it should not bo not to heat the val ve or jumper too hot. 


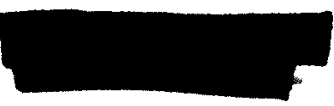

Material will flow as a liquid and once the flow has started, all that needs to be added is onough to make up for the loss by radiation and $108 s$ by the material flow through the system. This heat lose due to naterial flow lowers the temperature and 18 the indioation that material is being transforred.

The time required for transfer varies, of course, with the wolght and amount of preheating. Onoe material flow is started, an average of a pound a minute will be approximately the transfer rate. An experienced transfer man will be able to tell by the sound of the oapsule when it is rapped approximately how much material has flowed out and how moh is left behind. When the capsule is ompty, the valve is olosed and the capoule stem is frozen off. Disoonnoot the oapsule and replaco the plug aftor the usual proosutions have boon takon.

B. Emptying Large Containers

Containers oontaining from 40 to 70 pounds of material are preheated in a water bath or if thoy have stoam jackets are placed on steam for two hours or more. Conneotions is made botweon velves of two containers with a largo diameter line usually ranging in diameter from $1 / 4^{\prime \prime}$ to $3 / 8^{\prime \prime}$. Hoisting the preheated container over the large coolei container, conneot the valves. Warm both valves and the connooting line with burner and then open the valves. The reoeiving oontainer should be placed on $s$ oales so that the anount of material flowing over may be mosured and ao that it will be evident when the container is empty. The rate of moterlal transfor 111 bo very $1 \times \mathrm{rg}^{\circ}$ and in most oases will approaoh 10 pounds per minute.

\section{Reoords Systems}

Several types of reoords are kept in a routine fashion in the Materials Seotions. These reoords are extremely imortart both from a production atandpoint to tell the status of material whioh is being taken from the rack or being shipped, and from a control atandpoint to tell what the condition of the plant equiprent is. Great oare should be taken to be extromely acourate and punatual in the keoping of all reoords in this seotion. 
a. Sample Records

1. Uatorial Samplo Keoord

All samples taken from ospaules in the shop or taken from the plant will be recordod on thia form. The assay oolum is for the foreman's usis only. All data on this form will be reoorded on the sample card. All samples on this form will bo sent to Laboratory No. 1 .

2. Shipment Sample Records

All samplos taken from shlpping containers will be reoorded on this form. All data on this form will be reoorded on the sample card with the word Shipment written in. Depleted material samples, will also bo reoorded on this form with the serial number of the depleted tank recorded under the Container No. headingo

3. Raok Sample Reoorde

All samples taken in the plant from the racks will be reoorded on this form. All spocial samples will be recorded here also.

Each shift olerk w1ll hand the sample reoord forms into the office along with the material removal record. If at tho ond of tho shift all samples ordered are not returnod, the forman should leave the samplo reoord for the next shift to complete. This should apply only to raok
sample records.

b. Materiel Removal Reoord

(1) Write clearly the not woight of material from ouch capsule for rack and oircuit. Do lot writo the letters designating pounds and oum $\frac{100}{c e s}$ but merely sepurate pounds from ounces by a dash. For example, 75 pounds and 15 ovoes is witton $48,75 \% 15$

(2) Below the net woight write in the capsule number.

(3) Opposite the not weight, indioate the number of milkings that went into the No. 120 oapsulo. $\mathrm{T}_{\mathrm{his}}$ information will be obtained from the tap on the capsuie put there by the capsule ohanger. 
(4) Enter net weights of salvage material under sal vage heading.

(5) Obta in from the foreman the net woights, and raok and oircult numbers, for below-par material and onter on a regular torial removal recosd. This reoord will be kept for twenty-four hours of enoh day and handed in at the ond of each day.

\section{- Equipment Rovor da}

(1) Raok Equipment

Operations personnel wil sign out for all rack equipment in the $\log$ book provided.

(2) Capsules

Operations personnel will aign out capsules by number in the reok equipment log book.

\section{(3) Gauges}

Records olerk will ign gauges out to operation personnel in the gauge $\log$ book. Instructions in the front of the book will be followed. 


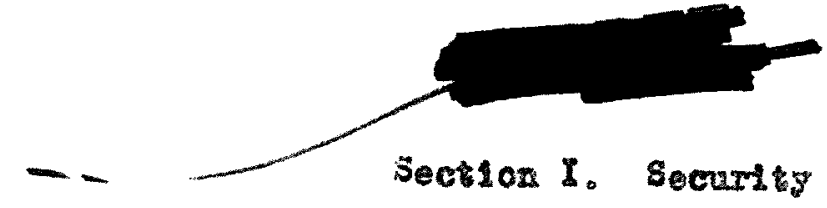

\section{RULES IOR SHOUAITY}

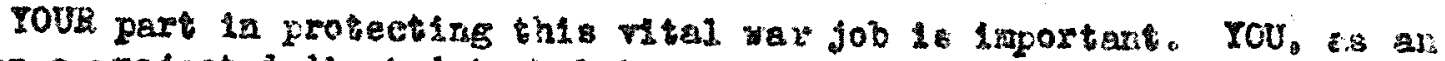

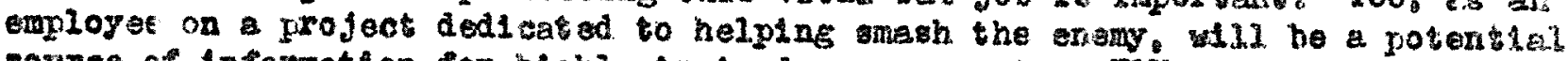

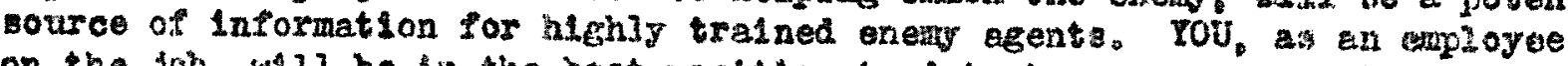
on the fob. W11 be la the best position to detect persone et fempting sabotage.

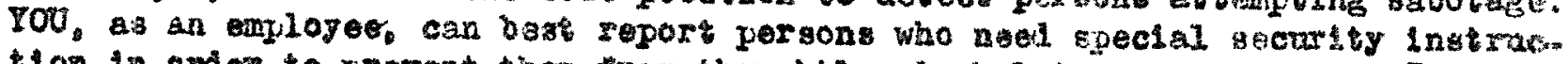
ton in order to grevent tinen from thowehtiessly helplng our enemies. The organized security protection gyter can famioh armad guarda ard strong Pences, but the real protsetion of this project is based on the Ecresstre. fall-time cooperation of 700 and other loyel Anertoan enplogeas.

200ur1.68:

It 1 inporsant thet you know and practivo the followist mas for White on the Jab

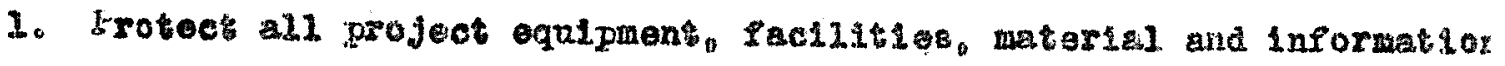

2. Wear ldentification badge in plain alght.

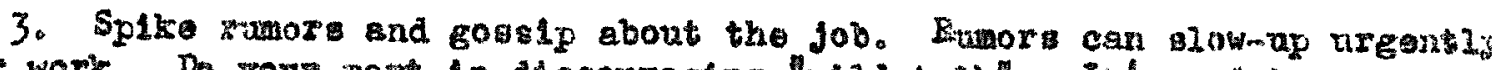

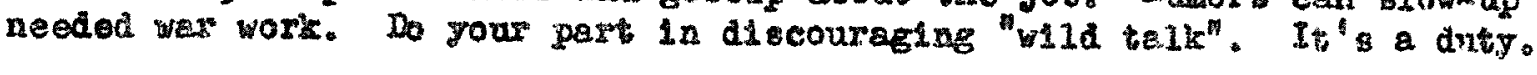

4. Ask yourele or talk about the job.

5. Enow four own job! If 1 it not necsenary in doing your job then Iorget it. Cursosits can be dangerous and selfisk. Beweraber wo are at WAR!

6. Begort ang enautkortzod pergons in jour cection.

7. Roport any employeon who seek to katow about your work without apecifle authority to have auch informatlon.

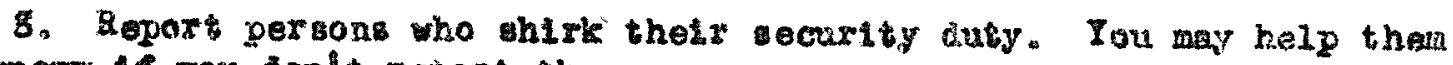
help the eneny if you don't retort then.

While Oef The Joh.

1. Rafrain Lrom Elving information ebout the joject work to yout femily ard close frionds.

2. frold discusing project work wh other groject mployees oven though thag are from gour section.

3. BR ON GUARD when in buses, trains, whases soclal fatheriners, end wh the nodehbora. 'Erotect project information al all tires. It" your daty!

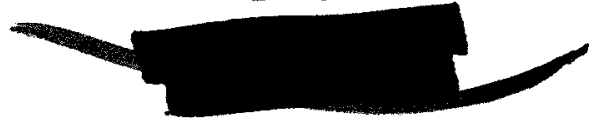




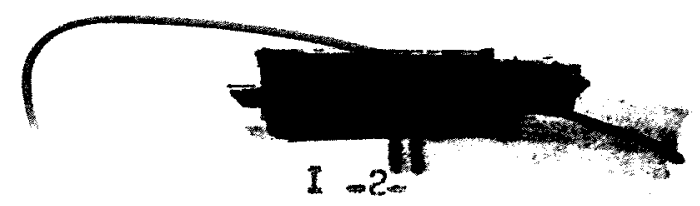

4. Beware of witing bis of infomation abot the groject in letters. You may be quilty in aldine the eneny by setulng "blts of informatson" 10086 .

5. THINK OF SEGURITY AT ALL TIIES, Our Lseting men and our troecherons enanies know this is a 24 hour a day was. Our duty to protect this was job lo laportant:

UABNIXG:

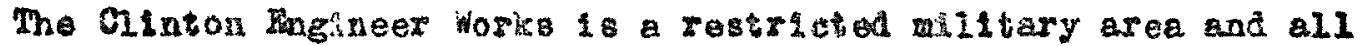
laws goveming ach aroas aply hertal. Sovere zonalties nte providod by

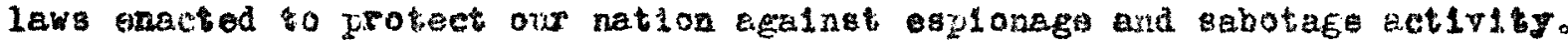

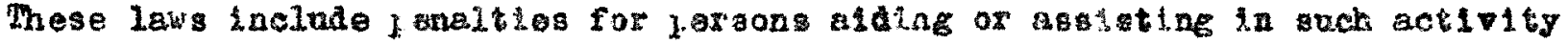
againt our coubry thle we are at was.
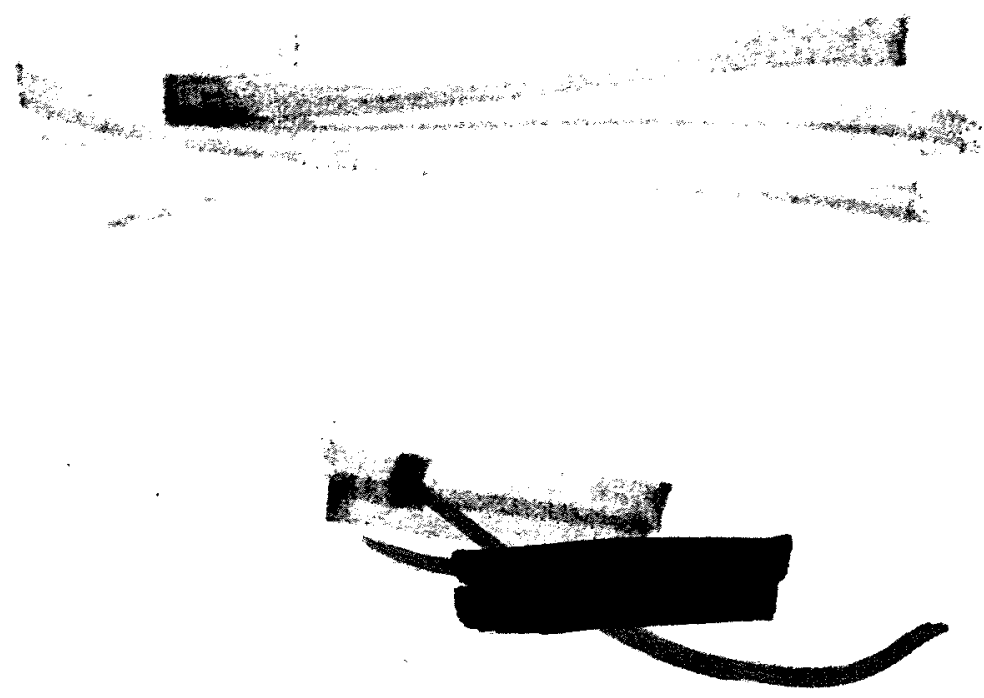
From:

Sent:

To:

Cc:

Subject:
Ridge, Ashley M (AR4)

Monday, September 28, 2009 1:42 PM

Prince, Rp (PPX)

Melton, Tish D. (LCE)

RE: Request for OSTI

OK RP I promise this will be the last one. :)

5-50 - Manual of Operations for the 5-50 Plant - 6/13/1988 - Barnett F. Dodge, Technical Director, Fercleve Corporation

I greatly appreciate all your help!

Thanks,

Ashley Ridge

Document Coordinator

K-1007 RM-1118 MS-7243

(865) 574-6764

\begin{tabular}{ll}
\hline From: & Prince, Rp (PPX) \\
Sent: & Monday, September 28, 2009 1:00 PM \\
To: & Ridge, Ashley M (AR4) \\
Cc: & Melton, Tish D. (LCE) \\
Subject: & RE: Request for OSTI
\end{tabular}

Ashley,

Thank you for the referrals. We will look for the listed reports and write back with search results.

R.P.

\begin{tabular}{ll}
\hline From: & Ridge, Ashley M (AR4) \\
Sent: & Monday, September 28, 2009 12:55 PM \\
To: & Prince, Rp (PPX) \\
Cc: & Melton, Tish D. (LCE) \\
Subject: & Request for OSTI
\end{tabular}

RP -

I have a few more that I need for OSTI.

1. Un-numbered-October 1996 - Site 16 K-725 Beryllium Building for Historical Information See K/HS-148 - A. Milton Stanley 